

\section{Baroque Lorca}

Baroque Lorca: An Archaist Playwright for the New Stage defines Federico García Lorca's trajectory in the theater as a lifelong search for an audience. It studies a wide range of dramatic writings that Lorca created for the theater, in direct response to the conditions of his contemporary industry, and situates the theory and praxis of his theatrical reform in dialogue with other modernist renovators of the stage. This book makes special emphasis on how Lorca engaged with the tradition of Spanish Baroque, in particular with Cervantes and Calderón, to break away from the conventions of the illusionist stage. The five chapters of the book analyze Lorca's different attempts to change the dynamics of the Spanish stage from 1920 to his assassination in 1936: His initial incursions in the arenas of symbolist and historical drama (The Butterfly's Evil Spell, Mariana Pineda); his interest in puppetry (The Billy-Club Puppets and In the Frame of Don Cristóbal) and the two 'human' farces The Shoemaker's Prodigious Wife and The Love of Don Perlimplin and Belisa in the Garden; the central piece in his project of 'impossible' theater (The Public); his most explicitly political play, one that takes the violence to the spectators' seats (The Dream of Life) and his three plays adopting, an altering, the contemporary formula of 'rural drama' (Blood Wedding, Yerma and The House of Bernarda Alba).

Andrés Pérez-Simón is an Associate Professor of Spanish at the University of Cincinnati. He has published essays on world literature, drama, film and literary theory. He is the author of Drama, literatura, filosofia: Itinerarios del realismo y el modernismo europeos (Fundamentos, 2015) and editor and translator of the critical anthology 'Despistemes': la teoría literaria y cultural de Emil Volek (Verbum, 2018). 


\section{Routledge Studies in Twentieth-Century Literature}

63 The British Stake in Japanese Modernity

Readings in Liberal Tradition and Native Modernism

Michael Gardiner

64 Theatre-Fiction in Britain from Henry James to Doris Lessing Writing in the Wings

Graham Wolfe

65 The Nationality of Utopia

H. G. Wells, England, and the World State

Maxim Shadurski

66 New Oceania

Modernisms and Modernities in the Pacific

Edited by Matthew Hayward and Maebh Long

67 French Thought and Literary Theory in the UK Edited by Irving Gob

68 Twentieth-Century Literary Encounters in China

Modernism, Travel, and Form

Jeffrey Mather

69 Twentieth-Century American Fiction in Circulation

Short Stories Written for Magazines and Republished in Linked

Story Collections

Matthew James Vechinski

70 Baroque Lorca

An Archaist Playwright for the New Stage

Andrés Pérez-Simón

For more information about this series, please visit: https://www.routledge.com 


\title{
Baroque Lorca
}

An Archaist Playwright for the New Stage

\author{
Andrés Pérez-Simón
}

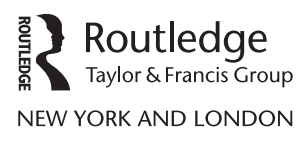


First published 2020

by Routledge

52 Vanderbilt Avenue, New York, NY 10017

and by Routledge

2 Park Square, Milton Park, Abingdon, Oxon, OX14 4RN

Routledge is an imprint of the Taylor \& Francis Group, an informa business

(C) 2020 Taylor \& Francis

The right of Andrés Pérez-Simón to be identified as author of this work has been asserted by them in accordance with sections 77 and 78 of the Copyright, Designs and Patents Act 1988.

All rights reserved. No part of this book may be reprinted or reproduced or utilised in any form or by any electronic, mechanical, or other means, now known or hereafter invented, including photocopying and recording, or in any information storage or retrieval system, without permission in writing from the publishers.

Trademark notice: Product or corporate names may be trademarks or registered trademarks, and are used only for identification and explanation without intent to infringe.

Library of Congress Cataloging-in-Publication Data

A catalog record for this title has been requested

ISBN: 978-0-367-82009-1 (hbk)

ISBN: 978-1-003-01140-8 (ebk)

Typeset in Sabon

by codeMantra 
For Ruth 

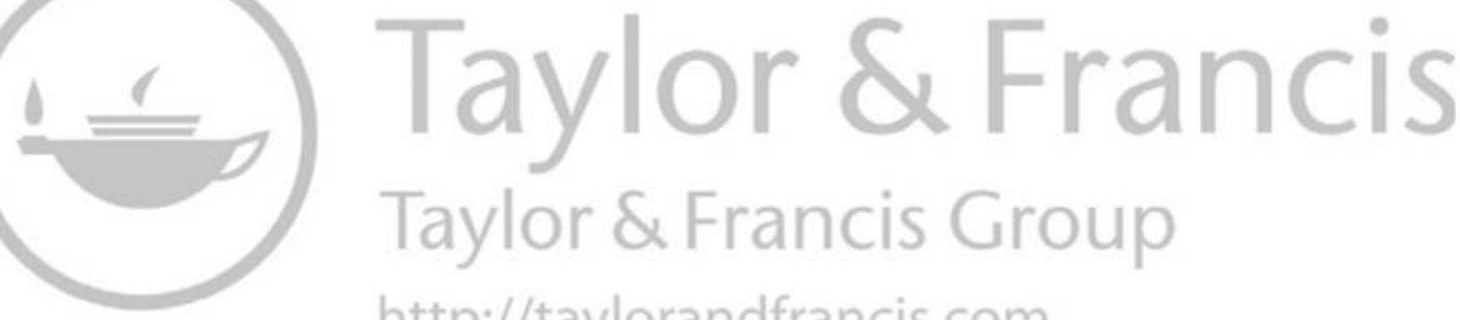
http://taylorandfrancis.com 


\section{Contents}

Acknowledgments $\quad$ ix

Note on Translations $\quad$ xi

Introduction 1

1 The Question of Allegory 23

2 Of Human and Puppets 45

3 Facing the Audience $\quad 67$

4 Revolution in the Playhouse 89

5 Writing for the Stage 111

Epilogue 137

Work Cited 141

Index 153 

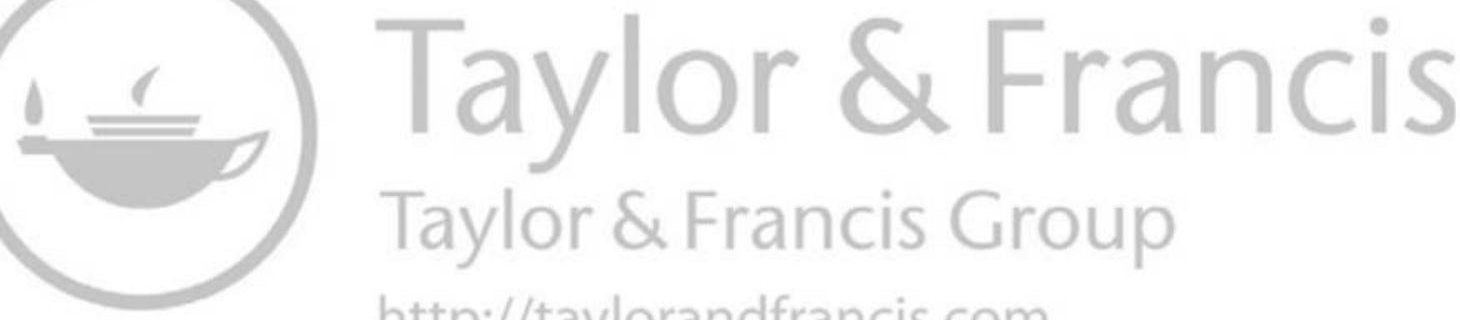
http://taylorandfrancis.com 


\section{Acknowledgments}

I am very grateful to the Taft Research Center at the University of Cincinnati, and the University Research Council at the same university, for their support over the years of writing this book. Special thanks go to the staff of the Federico García Lorca Foundation, in its old location in the building of the Residencia de Estudiantes in Madrid, for allowing me to access their archival material. I would also like to express my gratitude to Laura Arce, Raquel Barbero, Julia Escobar, Hunter Lang, Rodrigo Mariño and Tara Riley, who were always willing to provide great help and assistance whenever I asked for it. Finally, I would like to acknowledge the continued support of my family. Without them, this book would have never become a reality. 

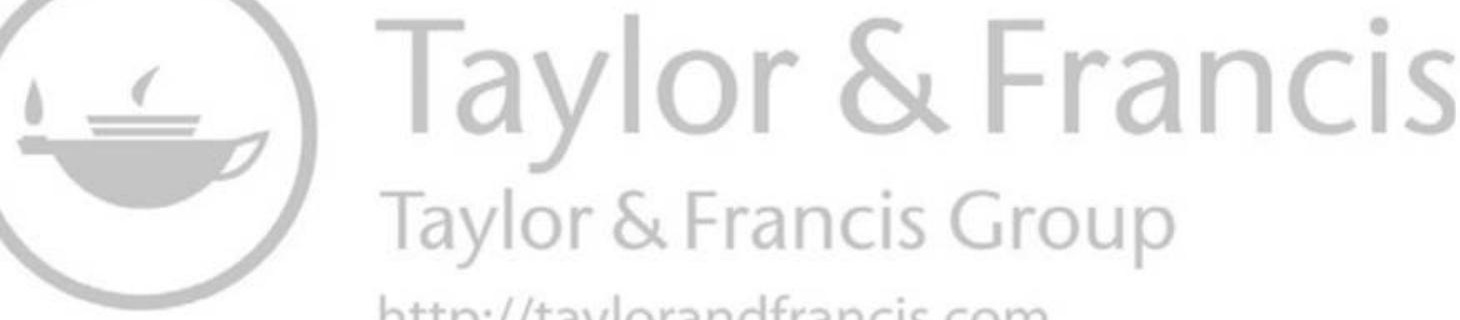
http://taylorandfrancis.com 


\section{Note on Translations}

Excerpts from Lorca's letters, public speeches and press interviews are taken from the third volume of his Obras completas, edited by Miguel García-Posada (Barcelona: Galaxia Gutenberg-Círculo de Lectores, 1996). This book is cited in the text as Obras. The translation of excerpts from Obras is mine in collaboration with Hunter Lang and Tara Riley, and the same applies to all quoted sources originally in Spanish and not available in English translation.

Quotes from Lorca's plays are from published English translations with the exception of the fragments pertaining to El maleficio de la mariposa (The Butterfly's Evil Spell). In this case, I provide my translation from Piero Menarini's critical edition of the text (1999). 

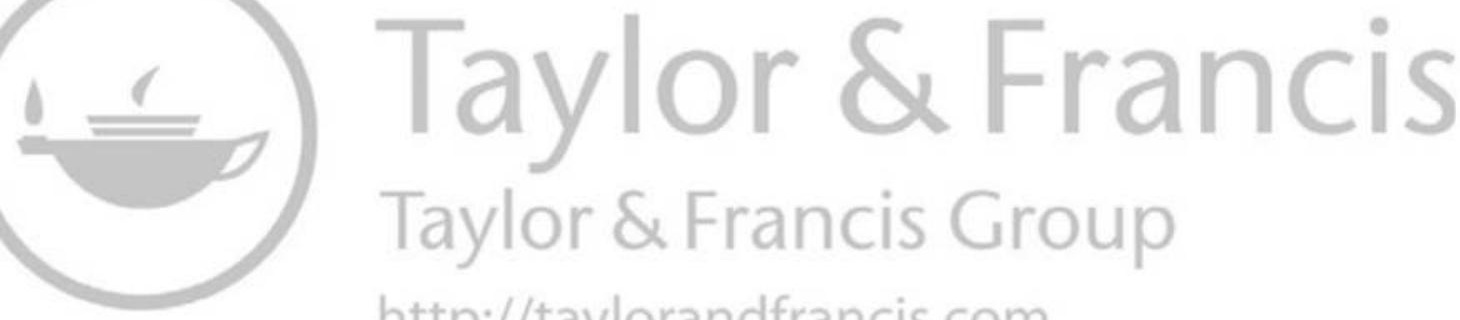
http://taylorandfrancis.com 


\section{Introduction}

In the late 1920s, Federico García Lorca found himself fighting the public perception that he was the quintessential Andalusian poet of Spanish modernism, the author of a distinctive kind of popular poetry that gave voice to the underrepresented Romani people of Southern Spain. As early as January 1927, still before the first edition of his triumphant book of poetry Gypsy Ballads (1928), Lorca had expressed his discomfort about what he perceived as a "gypsy myth" (Obras 940) that might damage his reputation in the long run. In a letter to his close friend and fellow poet Jorge Guillén, Lorca affirmed that the gypsies were for him "a literary theme, nothing else," and added, in a very avant-gardist fashion, that he "could equally be a poet of sewing needles or hydraulic landscapes" (Obras 940). Lorca feared that his identification with the Romani culture would render what he thought was an unfair image of him as an "illiterate, uneducated" (Obras 940) artist. Also in 1927, only a few weeks after writing to Guillén, Lorca ended a letter to the influential leftist author José Bergamín with a postscript that asked him to "stop considering me a gypsy, a myth that is more harmful to me that you could know" (Obras 955). The sensational success of his Gypsy Ballads in 1928 only reinforced Lorca's uneasiness about his public persona, and became a factor of importance in his decision to leave Spain in the summer of 1929 to initiate a nine-month stay in New York. This stay was followed by a three-month stay in Cuba before returning to Spain in June of 1930.

Lorca's personal journey in New York has been recreated in full detail by his biographers Ian Gibson and Leslie Stainton, but the textual reconstruction of his surrealist poetry book Poet in New York is still something 'in progress,' 'unfinished,' as uncertain as the material condition of most of Lorca's poetic and dramatic production. In a letter from January 1930 to his family, Lorca described Poet in New York, then in its final stage of completion, as "Something very intense, so intense that they will not understand it. It will provoke discussions and scandals" (Obras 1161, his emphasis). In New York, the author of the popular Gypsy Ballads adopted a typically modernist stance toward his art, one now conceived as both difficult and scandalous. Upon his return 


\section{Introduction}

to Spain in the summer of 1930, until 1935, Lorca made numerous-and contradictory-allusions to his New York poetry book, to which he referred first with the title of New York and, later, Introduction to Death in letters, interviews and public speeches. Lorca finally began working with a typescript of Poet in New York in August 1935, exactly one year before his assassination, overseeing decisions involving the selection of poems as well as their arrangement in the book. Lorca had agreed to print Poet in New York with Árbol, the publishing branch of Bergamín's avant-gardist magazine Cruz y Raya, but the Civil War brought the project to a halt and gave way to a sequence of editorial misadventures. In the summer of 1938, Bergamín intended to publish the book in Paris concurrently with a French translation by Paul Éluard. A French typist, with limited knowledge of Spanish, ${ }^{1}$ produced two copies of the typescript and also added annotations that Bergamín had brought with him when escaping the war in Spain. Spanish poet Juan Larrea, also in Paris, amended this copy. This 'French' copy, merged with the Madrid copy that Lorca had handed to Bergamín back in 1936, became the version of Poet in New York that Bergamín eventually published in Mexico City in 1940. Exiled in Mexico, following the victory of the Francoist army in 1939, Bergamín traveled to the United States and found a way to convince W.W. Norton to publish an English translation of Lorca's posthumous poetry book. This translation, commissioned to Rolfe Humphries, a New York high school teacher, was based on the second, uncorrected Paris copy, and Humphries checked it against a number of New York poems that Lorca had published in literary magazines while alive. ${ }^{2}$

Due to the multiple inconsistencies plaguing the first edition of Lorca's Poet in New York and its corresponding English translation, philological disputes ensued right after the publication of both texts in Mexico City and New York back in 1940. In 2013, seventy-three years after its first publication, a reconstructed edition of Poeta en Nueva York came out, thanks to the decades-long work of renowned Lorca scholar Andrew A. Anderson. It is still early to determine if the dozens of translations of Lorca's book, in particular the English one, will be revised accordingly. However, even after Anderson's edition, there is still an ongoing debate on the number and nature of a series of New York photographs that Lorca collected himself in 1929, originally intending to overcome the distinction between text and image in his book of poems (Herrera 108-20). The discussion surrounding what the 'true' version of Poet in New York is remains open. I believe that it will stay open indefinitely because of the ephemeral condition of Lorca's writings, which consist of a wide range of artifacts notoriously affected by external elements. Lorca's writings are comprised of lost and fragmented manuscripts, containing typographical errors and conflicting testimonies on his artistic plans. The incomplete state of his writings makes them irreducible to a pure and original state of unity. 
This succinct review of the editorial afterlives of Lorca's Poet in New York has intended to show to what extent incompleteness constitutes a main feature of Lorquian poetry, an aspect that has fueled editorial debates for decades up to this day. Incompleteness occupies an even more significant dimension when one abandons philological debates to focus instead on Lorca's involvement in the theater, first as dramatic author in the 1920s and later as both playwright and director in the 1930s. To be more precise, the concept to be considered here is not incompleteness but, rather, ephemerality. Given the performative nature of theater, any kind of archeological approach to a particular set of practices of production and reception, in this case in the theatrical industry of interwar Spain, needs to acknowledge that the ephemeral nature of the theatrical event is not ultimately reducible to the restorative logic of the archive. While this is a non-controversial statement widely accepted by theater scholars and practitioners today, the international image of Lorca is still very much the result of the amalgamation of two interpretive strategies that ignore the obvious fact that his theater was inscribed in a specific performative and historical context. The first of these strategies consists of a text-centered approach that relies on thematic and symbolic analyses to explain the 'universality' of Lorca's three agrarian tragedies (Blood Wedding, Yerma, and The House of Bernarda Alba). While Lorca's tragedies are situated in the distinctively Catholic milieu of Southern Spain, we are told, the female characters in these plays embody the universal values of freedom and passion in contrast to repression and reason, respectively. These values are supposed to be represented by figures such as the Bride in Blood Wedding, Yerma in the homonymous play, and Adela, the youngest of Bernarda's daughters, in The House of Bernarda Alba. I argue that this narrative relies on a transit from the local to the universal that simply bypasses the condition of being-for-the-theater of Lorca's works. This is at the expense of ignoring crucial factors such as the fact that Lorca had to write roles for actress-managers to gain access to the industry or that he modeled his agrarian trilogy after the contemporary genre of the drama rural, which provided Lorca with a formula to adopt and alter in order to conquer the contemporary stage. The second strategy I want to point out here consists in explaining Lorca's trajectory in the theater according to a teleological model that ultimately depends on the same tenets of biographic criticism that academics claim to have expelled from humanities departments decades ago. With a few exceptions, Lorca is routinely taught as a brilliant poet who, after a series of inconsequential dramatic attempts, eventually created a masterful trilogy of agrarian tragedies right before the fascists killed him in the early days of the Spanish Civil War in 1936.

The two interpretive strategies I have just mentioned often operate together, feeding each other. If the agrarian trilogy attracts international attention, it is because these three plays are prone to thematic 


\section{Introduction}

generalizations about the frustrated desires of Lorca's female figures and, at the same time, these plays offer us a glimpse of Lorca's own violent death. In this respect, it has proven a difficult task to avoid the influence of what can be called for the lack of a better term, the "Lorca myth." As early as 1989, in the wake of the numerous publications, conferences and literary festivals organized on occasion of the fifty years of Lorca's assassination (1936-86), Paul J. Smith objected that it was "almost an article of faith that in Lorca literature and life are one" (Body 107). Almost three decades after Smith's assertion, the theater of Lorca has been approached from multiple critical angles, yet his biography seems very much alive even in those scholarly pieces that invoke the antihumanistic foundations of postmodernism. Sarah Wright has observed how critics still rely on Lorca's life or, "more specifically, his death" ("Theatre" 40), to perpetuate two mutually reinforcing ideas about his theater, namely that its core expresses "the struggle between freedom and repressed desires," and that "the backdrop of a Spain threatened by Fascism can be seen as the mise-en-scène (in varying degrees of disguise) for his plays" ("Theatre" 40). This biographical bias, in conjunction with what I have described as a predominantly textual analysis of Lorca's theater, has legitimized superficial theories about the importance of Lorca's sexuality in his own creation. As Maria M. Delgado notes, theories that posit that Lorca's "crafting of strong female roles ... [was] a veiled portrait of displaced homosexual desire ... simply fail to consider the material conditions in which Lorca crafted his works, dominated by powerful actress-managers like Margarita Xirgu and Lola Membrives" (35). The present study proposes an alternative to this traditional paradigm previously denounced by Smith, Wright and Delgado, while still acknowledging the unavoidable existence of "a trajectory of past scholarship that has played a decisive role in shaping how his theatre has been read and produced and the ways in which this has been bound with the Lorca myth" (Delgado 33). My contention here is that this vicious circle can be broken by first expanding the Lorquian dramatic canon and, later, considering it a collection of dramatic writings created for the theater, in direct response to the conditions of Lorca's contemporary industry. Throughout this book, I also argue in favor of inserting the theory and praxis of Lorca's theatrical reform in the wider context of theatrical modernism precisely to contest biographical interpretations of this theater.

The goals of this book are threefold. The first one is to bring the reader's attention to a diverse corpus of Lorquian plays beyond the limits of his popular agrarian trilogy, conceptualizing Lorca's trajectory in the theater as distinctively modernist since 1920, when The Butterfly's Evil Spell, his first play, premiered in Madrid. Throughout his life, Lorca opposed commercialism, yet he accepted his role as producer of commodities as part of a long-term plan to create a theater for a new audience in 
interwar Spain, a reformist project that Lorca intertwined with revolutionary politics in the 1930s. Second, I study different aspects of Lorca's engagement with his contemporary theatrical industry, with an emphasis on his role as theoretician of a new stage (as early as 1923 he praised the use of puppets, for example, as will be discussed in the second chapter) and his experience as director of the state-subsidized itinerant theater company La Barraca (1932-35). I will also devote attention to Margarita Xirgu, a leading actress-impresario, and Cipriano Rivas Cherif, the Spanish theater director best acquainted with the theories of European modernism. Xirgu staged Lorca's Mariana Pineda in 1927, and from 1930 to 1935 the duo Xirgu-Rivas Cherif staged four of Lorca's dramas. In 1935, Rivas Cherif also directed Lorca's adaptation of Lope de Vega's The Foolish Lady. Third and last, I propose a reading of Lorca as archaist playwright and director, for he saw the tradition of Spanish Baroque as the source for the new dynamics of spectatorship he intended to establish. While Lorca's engagement with the historical avant-garde has been scrutinized in detail for decades, and there is no need to deny the obvious importance of surrealism, cubism and expressionism in his poetry and drawings, it is necessary to acknowledge that the theory and practice of these artistic movements cannot account for Lorca's activity in the theater. For such aspects of his theater as the device of theater within theater, the symbolic and allegorical construction of characters, and the intersection of ritual and theater refer back to the Spanish tradition of the auto sacramental, epitomized by Pedro Calderón de la Barca. Moreover, Lorca's tragicomic farces, written for actors and puppets, have their starting point in Miguel de Cervantes' interludes. Lorca himself verbalized his archaist gesture in an early speech as director of $\mathrm{La}$ Barraca before an audience of university students and members of the progressive government of the Spanish Second Republic, in October of 1932. To the surprise of politicians who were expecting a transparent leftist discourse from the director of the newly created state-subsidized theater company, Lorca claimed the legacy of Calderón and Cervantes, arguing that "the pendulum of Spanish theater oscillates violently between the antagonistic worlds" (Obras 218) of these two authors.

\section{The Playwright as Producer}

Lorca's trajectory in the theater was a lifelong search for an audience. After his negative experience in the commercial arena in 1920-his first play, The Butterfly's Evil Spell, only lasted four nights in the Teatro Eslava of Madrid-Lorca spent the following years working concurrently on different projects (puppet plays, Mariana Pineda, The Shoemaker's Prodigious Wife, The Love of Don Perlimplin and Belisa in the Garden) while at the same time trying to establish contact with the leading figures in the contemporary theatrical industry. Lorca's letters of 


\section{Introduction}

the 1920 s reveal his increasing awareness of his condition as a producer ${ }^{3}$ of commodities for a theater industry that functions according to the laws of supply and demand. In a letter to his family from late 1924, for example, Lorca announced an upcoming production of Mariana Pineda by Gregorio Martínez Sierra, the same director and theater impresario who was behind his theatrical debut four years before. Lorca describes Martínez Sierra's alleged enthusiasm in plain economical terms when explaining that he "is enthused as an impresario, and he says that the play could be as successful as Zorrilla's [Don Juan] Tenorio" (Obras 818). Adapting his dramatic writing to the star system of the time, one dominated by actresses, Lorca was fully confident that Catalina Bárcena, Martínez Sierra's partner and leading actress, would gladly play the role of the nineteenth-century political heroin Mariana Pineda, executed for conspiring against the absolutist regime of Ferdinand VII in 1831. External circumstances delayed the production plans and Lorca, refusing to stage the play later in the year-which would have required the play to premiere outside of Madrid-decided to pitch his historical play to the actress-impresario María Guerrero ("she has a gorgeous niece who just revealed herself to be a great actress," Obras 828). Lorca's letters from 1926 evidence his confrontational stance against commercialism ("Dealing with impresarios is the most repugnant thing in the world because they are all beasts. Theater in Spain is in the hands of the worst kind of people," Obras 893), but also his willingness to see his theater staged again. In 1926 alone, Lorca offered his script to Carmen Moragas, leading actress of the Teatro Español in Madrid who had recently moved to the Teatro Fontalba in Barcelona (Obras 893); with the help of Eduardo Marquina, champion of the commercially successful and ideologically conservative genre of teatro histórico, he reached out to the actresses-impresarios Margarita Xirgu and Lola Membrives (Obras 893); finally, Lorca also tried to sell the role of Mariana as ideal for the wife of the actor-impresario Santiago Artigas, who asked him for some time to run numbers before giving a firm response ("they are forming their economic plans these days to give me a clear answer," Obras 896).

In 1927, the year of his eventual return to the commercial stage after a lapse of seven years, Lorca's oppositional attitude toward the Spanish theatrical industry was even more accentuated than before. Sharing a deep personal and artistic affinity with Salvador Dalí, his fellow student in the Residencia de Estudiantes, Lorca referred to a press article announcing the upcoming production of Mariana Pineda as "putrefactisimo" (Obras 975), a variation of the term he and Dalí created to mock the conservative artistic factions of Madrid, the "rotten ones" [putrefactos]. Lorca even got to the point of fantasizing about a future career in the theater without having to interact with the members of the industry. In a letter to friend and drama critic Melchor Fernández Almagro, Lorca confessed to being "scared of the world of theater" and asserted that his 
physical distance from it would be his "future norm as dramatic author" (Obras 975). When the production of Mariana Pineda became imminent, however, Lorca gladly accepted to travel to Barcelona to direct the play, and enthusiastically recruited Dalí as stage designer in what constituted their only collaboration in the theater. In April, writing from Madrid before leaving for Barcelona, Lorca asked his family for an urgent money transfer to finance a new life that included gifts to the actress Xirgu and inviting theater critics to generous meals ("Such is life in the theater," Obras 985). Mariana Pineda premiered in Barcelona in July 24,1927 , and the positive response from both spectators and critics signaled Lorca's entrance in the circuits of commercial theater seven years after the four-night run of The Butterfly's Evil Spell.

In October 12, 1927, Xirgu opened the theater season at the Teatro Fontalba of Madrid with Mariana Pineda, and in 1929 the actressmanager toured Southern Spain with this play, a tour that eventually took her to Granada, Lorca's birthplace, in May of that year. A group of critics and local personalities in Granada organized a homage to Lorca and Xirgu on the occasion of Mariana Pineda coming to town, just another sign of Lorca's acceptance into the system, but by this time Lorca's attitude toward his play and the contemporary industry had shifted from doubts to plain rejection. In the speech he gave in the banquet in his honor, Lorca complimented Xirgu on her acting but at the same time made very clear that "My drama is weak like a novice's, and while it has traits of my poetic temperament, it doesn't respond well at all to my criteria about the theater" (Obras 195). In June 1929, one month after his public rejection of Mariana Pineda, Lorca left Spain for the first time in his life to embark in a nine-month stay in New York, where he fully committed himself to renovating the Spanish theater industry. There he formulated his ideas of change in very radical terms, expressed in a letter to his family in October of that year: "I have started to write a thing for the theater that may be interesting. One must think about the theater of the future. Everything that exists now in Spain is dead. Either the theater will change its roots, or it will be gone forever. There is no other solution" (Obras 1144). During his transformative experience in New York, Lorca developed the idea of The Public, the play he alluded to in his letter to his family. He was writing the The Public during his threemonth stop in Havana, in spring of 1930, and completed the manuscript in Granada in August of that year.

Upon arrival to New York in the summer of 1929, Lorca continuously advocated for the staging of The Love of Don Perlimplin and Belisa in the Garden, a play banned by the military government of Miguel Primo de Rivera a few months earlier, as well as his puppet play The Billy-Club Puppets. In a letter to his family in October 1929, Lorca felt confident that his newly established friendships with patrons, all of them female, would eventually lead to the staging of English versions of both plays 


\section{Introduction}

(Obras 1145). In this letter, he raised two issues that are inherently modernist: the problem of finding an audience for a minority theater and the question of obscenity in art. Lorca expressed his enthusiasm for the existence of an extended network of avant-gardist playhouses in New York and believed that this feature, in combination with the patronage from affluent art lovers, would protect his theater from commercialism (Obras 1145-6). Lorca also thought his theater would be free from the same accusations of indecency that had prevented the staging of The Love of Don Perlimplin and Belisa in the Garden in Madrid on grounds of the allegedly pornographic nature of the play (Obras 1146). Although Lorca's plan to stage his theater in New York did not materialize, ${ }^{4}$ his contact with select cultural circles led him to believe, upon returning to Spain in the summer of 1930, that theater clubs were the natural space for his playwriting and directing work. Back in Spain, Lorca had the opportunity to stage his theater and be progressively more involved in the task of directing, thanks to his contact with Rivas Cherif. He was the manager of El Caracol, the theater club that was rehearsing The Love of Perlimplin with Belisa in the Garden when the play was banned in early 1929. Rivas Cherif had been involved in the creation of short-lived minority theaters in Spain as early as 1920, while he was concurrently pursuing a comprehensive reform of the tasks of acting, directing and stage design. ${ }^{5}$ Throughout the 1930s, Lorca's collaboration with Xirgu and Cherif granted him enormous commercial success (above all, Yerma in Madrid and Barcelona in the 1934-35 season, and a new production of Blood Wedding in 1935, two years after it was premiered by Josefina Artigas' company in Madrid.) In parallel with commercial venues, Lorca worked closely with one theater club, the Club Teatral de Cultura, later renamed Club Anfistora. This theater club staged The Love of Perlimplin with Belisa in the Garden in 1933, four years after its ban.

Lorca was well aware of the fact that his prestige as playwright was much inferior to his reputation as poet when he returned to Spain in the summer of 1930. Lorca disliked the contemporary stage to the point that he defined it as theater "made by pigs, for pigs" (Obras 424) in an interview from 1933, yet it was not until the sensational success of Yerma in the Teatro Español of Madrid, in 1934-35, followed by a new production of Blood Wedding in Barcelona and Madrid in 1935, that Lorca found himself with enough cultural capital to publicly lay out his plans of change. After obtaining commercial success, Lorca insisted on emphasizing the importance of his 'impossible theater,' in particular The Public, ${ }^{6}$ over his acclaimed dramas. Besides the theater clubs and the commercial venues that he had accessed, thanks to Xirgu and Rivas Cherif, there was a third experience in the theater that was crucial in this period that spanned from 1930 to 1936. I am referring to Lorca's role as director of La Barraca, from 1932 to 1935, one that granted him the opportunity to establish close contact with audiences from rural and 
isolated towns spread throughout Spain, a demographic group that was the antithesis of the spectators who consumed commercial theater in Madrid and Barcelona. With La Barraca, Lorca rehearsed new spatial dynamics in montages of baroque plays in open and public spaces of small villages in rural Spain. Moreover, he realized the impossibility of separating the 'inside' from the 'outside' of the theatrical event. When accepting the position of director of this itinerant company, Lorca had expressed his allegiance for non-political theater (Obras 393), but the numerous incidents that surrounded the performances of La Barraca lead him to understand the dialectic relationship between stage and audience in the politically charged times of the Spanish Second Republic (1931-36).

\section{Lorca Studies: A Metacritical Account}

In recent years, a change of critical paradigm has taken place in Lorquian scholarship as critics have moved away from text-centered analysis to endorse an approach that sees Lorca as a "committed theatre practitioner," someone who "strove to see his work produced on stage" (Wright "Theatre" 40). Delgado's comprehensive review of Lorca's performance histories in Spain and abroad, published in 2008, constitutes a good example of this most recent scholarly interest. Critics have also questioned the received idea that overly theatricalist plays such as The Public constitute some kind of closet dramas to be consumed in private or, at best, "minor experiments en route to the major tragedies" (Wright "Theatre" 42). In dialogue with this critical reorientation within the field of Lorca studies, this book describes Lorca's trajectory in the theater as a fullfledged project of artistic and social reform with multiple elements in common with the theory and praxis of theatrical modernism. One aspect of central importance at this respect is Lorca's authorial awareness of his role as producer of commodities since the early 1920s, as well as his self-realization, later in his life, of the impossibility of establishing a clear distinction between aesthetics and politics.

I recognize Lorca's theater as "genealogical" in the sense that Martin Puchner articulates the term in his book Stage Fright. Modernist discourses on theater, Puchner explains, revolved around "an irreversible dissociation of the value of theatricality from the realities of the actual theater" (7). The existence of what Puchner describes as an "antitheatrical" tradition in modernist theater was not a simple revival of past anti-mimetic or puritan impulses but rather the result of the intersection of philosophical, narrative and dramatic practices that crystallized in theories of cultural modernism (Nietzsche, Benjamin, Adorno) as well as in poetics that privileged the page over the stage (Mallarmé's closet dramas) or that thought anew the role of the actors as performing bodies (from Gordon Craig to Brecht and Beckett, the list is long, see Puchner 


\section{Introduction}

Stage 7-13). In this respect, Lorquian works such as The Public and The Dream of Life emerge as paradigmatic cases of the contradictory nature of theatrical modernism. They explicitly call for a reform of the contemporary commercial stage while, at the same time, they question the very notion of theater and theatricality. In the fifth and final act of The Public, a play I will discuss in the third chapter, the Director discusses the failure of his scandalous production of Romeo and Juliet with the newly arrived figure of the Prestidigitator. The Prestidigitator explains to him that the audience can be conquered by making use of supernatural elements such as Diana's flower in A Midsummer Night's Dream: "If love is pure chance and Titania, Queen of the Fairies, fell in love with an ass, then, by the same reasoning, there wouldn't be anything extraordinary about Gonzalo drinking in the 'music hall' with a boy dressed in white sitting on his lap" (Public 43-4). The Director, however, refuses to accept the Prestidigitator's offer of illusionist tricks that would allow him to justify the randomness of sexual desire in future productions. The Director replies that “that's deception! That's theater! If I spent three days battling the roots and the pounding waves, it was to destroy theater" (Public 44). This final discussion in The Public revolves around the notion of theater as a practice that lacks authenticity, and this time it is subject to question not by traditional enemies of the stage but by a fictional alter ego of Lorca himself.

The present study proposes a dialogue between recent developments in modernist studies, in particular in the field of modernist drama and theater, and a body of critical works that Lorca scholars have produced in the past decades in a context of multiple debates and editorial controversies. While notable editorial events have significantly changed the way in which the community of Lorca scholars has tackled Lorca's theater, these new critical vistas have rarely resonated among the wider group of international scholars who in many cases still rely on received wisdom on Lorca's agrarian trilogy. The latter are not generally aware, for example, of such critical milestones as Rafael Martínez Nadal's first edition of the manuscript of The Public in 1976, followed two years later by the release of a single volume containing the play and a second unknown text that French scholar Marie Laffranque titled Comedia sin titulo, later translated into English as Play Without a Title. These two dramatic texts were unknown with the exception of two acts of The Public that Lorca gave to print in 1933. In 1998, in reference to a recently published drama companion that did not even mention these two plays in the section devoted to Lorca, Smith noted that "there seems little doubt that an earlier publication of the unplayable plays would have counteracted the pernicious and pervasive folkloric stereotypes that still determine foreign responses to García Lorca" (Theatre 4). To a significant extent, the situation Smith denounced two decades ago remains the same today. The Norton Anthology of Drama, in its last edition of 2009, features 
The House of Bernarda Alba, celebrated as Lorca's "masterpiece" (541), and makes no reference to the theoretical and practical implications of Lorca's project of an 'impossible' theater. Moreover, it briefly describes The Public as essentially a closet drama, calling it the author's "most private work" (540). Published just one year after the Norton, a new anthology, The Routledge Drama Anthology and Sourcebook: From Modernism to Contemporary Performance, does indeed select The Public out of all Lorquian dramas. This editorial decision constitutes a very explicit gesture to situate Lorca in dialogue with Jarry, Apollinaire, the surrealists and the futurists, grouped in the subsection devoted to the historical avant-garde. In the introduction to this section, titled "The Historical Avant-Garde: Performance and Innovation," Maggie B. Gale stresses the theatrical nature of a play "which makes constant references to the relationship between the theatre work and its audience" (187) and points to its complex structural patterns (changes of scenery, collapse of the identification between actor and character and so on) as "one reason, perhaps, why The Public was not produced professionally until the late 1980s" (187), a logical explanation that nonetheless does not account for the fact that the manuscript was believed to be lost for forty years until the Lorca estate finally authorized its publication.

The appearance of this single volume containing The Public and Play Without a Title, with commentaries by Martínez Nadal and Laffranque, respectively, constituted the beginning of what I define as the second phase of the Lorca scholarship. This period, characterized by the release and interpretation of unknown texts, covers approximately a period of two decades, from 1978 to 1998 . (Any previous scholarly contribution before this year of 1978 would fall into the first phase, comprising mostly studies on Lorca's theater published in the 1970s, in parallel with the rise of semiotic and psychoanalytic methods in the academy.) This editorial event of 1978 was followed by the publication of Lorca's juvenilia, a bunch of heterogeneous texts that the Lorca estate first made available to some scholars in the mid-1980s and eventually sold to the Spanish Ministry of Culture in the early 1990s. In 1994, Cátedra publishing house released three edited collections of Lorca's early incursions in prose, poetry and drama, respectively. Spanishspeaking scholars (none of these early texts are available in English) are now aware, for example, that between the ages of 19 and 22 Lorca authored the monodrama Theater of Souls (1918), as well as numerous religious-philosophical dialogues inspired in his readings of Plato, such as The Primitive Auto Sentimental (1917), Of Love. Theater of Animals (1919) and Shadows (1920). In parallel to the publication of a set of unknown texts, the 1980s and the 1990s witnessed such cultural milestones as the celebration of the fiftieth anniversary of Lorca's death, in 1986, with the subsequent spike in the number of essays, books and conference proceedings in the year that followed; the creation, in 1984, of 


\section{Introduction}

the Federico García Lorca Foundation, taken ten years later to the second floor of the Residencia de Estudiantes where he had crossed paths with Salvador Dalí and Luis Buñuel in the 1920s; the publication of the allegedly definitive Collected Works, in the form of four volumes edited by Miguel García-Posada and published by Galaxia Gutenberg-Círculo de Lectores, in 1996-97; and, finally, the celebration of the one hundred years since Lorca's birth in 1998, with the full involvement of all types of political, artistic and academic authorities in Spain. However, in the midst of this collective enthusiasm over the figure of Lorca, now hailed as the most precious cultural capital of Granada, Andalusia and Spain, some critics expressed their reservations toward what they perceived as an uncontrolled overgrowth of the Lorca industry. In his essay contribution to the proceedings from the major Lorca centenary conference, a volume subsidized by the government of the province of Granada, Luis Fernández Cifuentes openly referred to a feeling of "exhaustion" "Qué" 221) that was the result of what he perceived as an excessive iteration of critical clichés in the Lorca scholarly industry. Fernández Cifuentes denounced an overabundance of simplistic hermeneutic strategies that tended to revolve around a restricted canon of texts-in the case of Lorca's drama, his rural trilogy-while ignoring the points of resistance that Lorca's works presented to totalizing thoughts ("Qué" 223-8). I define the twenty years that went from the editorial event of 1978 to Lorca's centenary in 1998 as the "phase two" of Lorca scholarship. This third stage, which begins in this iconic year of 1998 and extends up to today, is characterized by a greater attention toward dramatic works previously defined as "minor," "immature" or simply "posthumous." Fruitful debates have developed out of the seeds that a minority group of scholars planted already in the 1990s (Fernández Cifuentes "Qué" 229). The present study book contributes to this conversation within the Lorca community while also addressing an international community of drama and theater scholars who are not aware of these recent debates around the figure of Lorca.

\section{Description of Chapters}

"The Question of Allegory," the chapter that opens this book, studies the first two plays Lorca staged in commercial theaters, The Butterfly's Evil Spell and Mariana Pineda, premiered in Madrid and Barcelona in 1920 and 1927, respectively. Despite the support of director-manager Gregorio Martínez Sierra, The Butterfly's Evil Spell had a run of only four nights in the Teatro Eslava, a prestigious commercial venue owned by Martínez Sierra himself. Both critics and spectators reacted negatively to the symbolist patterns of characterization in Lorca's first play. The mise-en-scène of The Butterfly's Evil Spell descended from the tradition of Paul Fort's Théâtre d'Art and Lugné-Poe's Théâtre de l'CEuvre, 
two theaters that Martínez Sierra had known first-hand when visiting Paris in the early years of the century. In this regard, it is significant how two of the reviewers directed their criticisms not so much on the young Lorca but on Martínez Sierra himself, for allegedly abandoning a national theatrical tradition to embrace the foreign aesthetics of French symbolist drama. More generally, in terms that are not theater-specific, The Butterfly's Evil Spell can also be defined as "symbolic" art due to its condition of standing for something else, of making evident the distance between the literal and what is to be perceived as symbolic or allegorical meaning. A drama mostly written in verse, it portrays a story of impossible love between a stranded butterfly and the cockroach-turnedpoet Curianito. The theater critic at $E l S o l$ newspaper, for example, condemned The Butterfly's Evil Spell for featuring cockroaches that could never "become poetic symbols" and whose presence on the stage only produced a "watered down and confusing allegory" [alegoría diluida $y$ confusa]. This was just one of the many attacks showing a feeling of unpleasantness in response to the darkening of what was expected to constitute a transparent relationship between performing subjects and dramatic characters. The Butterfly's Evil Spell contains different constructive aspects that would later become defining of Lorca's entire trajectory in the theater. Among these elements, the play's prologue stands out as an ambivalent fragment associated with the indeterminate agency of the Author, one that can be interpreted as a fictional character carrying that name, but also the real person behind the dramatic text, in this case the young aspiring playwright Federico García Lorca. The prologue paraphrases the plot of A Midsummer Night's Dream to justify the randomness of love, setting the precedent for the speech of the Director in The Public, when the Director also resorts to this very same motif to justify his production of Romeo and Juliet. From this wider perspective, Shakespeare's comedy thus functions as a recurrent reference that ties The Butterfly's Evil Spell, The Public and, finally, The Dream of Life, for in the latter the Director and his cast of actors are rehearsing A Midsummer Night's Dream when violence erupts inside the playhouse.

Seven years after the clash with the audience that was The Butterfly's Evil Spell, Lorca had a second chance to confront commercial audiences with Mariana Pineda, a play that premiered in Barcelona in June of 1927. Lorca's letters from 1924 to 1927 evidence his increasing frustration at his marginal role as producer of commodities in a context dominated by impresarios and star actresses. In the mid-1920s, in parallel to the growing body of poetry that made him an emerging figure in the Residencia de Estudiantes and the Spanish avant-garde circles, Lorca intended to establish himself as playwright while also becoming progressively more interested in the task of directing theater. The experience of taking Mariana Pineda to the stage was indeed crucial in his education as theater director, to the extent that his letters from these three frustrating years 


\section{Introduction}

prefigure the central motives that were later highly visible in his multiple public interventions throughout the 1930s. Lorca conceived Mariana Pineda as a way to rectify the failure of the premiere of The Butterfly's Evil Spell, a play that was sabotaged by the audience, as noted earlier, and only partially savaged by the critics as an exercise of talented 'literary' writing. In dramatizing the final days of Mariana Pineda, a liberal heroine executed in 1831 for conspiring against the absolutist regime of Ferdinand VII, Lorca voluntarily situated himself within the parameters of the contemporary genre of 'historical drama' mastered by Marquina. From a perspective of textual analysis, Mariana Pineda thus constitutes a typically 'immature' or 'minor' work, one that stands in stark contrast to Lorca's later achievements-Mariana Pineda is a historical verse drama of flourished style, one in the antipodes of the simplicity of language and spaces in The House of Bernarda Alba, for example. This is, however, a partial judgment that does not account for the fact that Mariana Pineda represented what Miguel García-Posada has defined as Lorca's "first pact with the theater industry" (Introduction 11), a precedent for Lorca's incursion in the also commercially popular genre of the drama rural in the 1930s. Moreover, it was by writing Mariana Pineda that Lorca first entered in contact with actress-manager Margarita Xirgu who, as noted earlier, accepted to stage the play in 1927.

After situating Mariana Pineda in its most immediate artistic context, I conclude this first chapter with a review of interpretations of this play as a political allegory that irradiates meaning due to the intrusion of elements coming from the 'outside' of the work. Mariana Pineda obtained a warm response from the Barcelona audience, but what I find most interesting is how critics saw the heroine Mariana as a figure of resistance to Primo de Rivera's dictatorship, a military rule that would eventually extend until early 1930. Lorca, however, tried to discourage political interpretations of this play and publicly aligned himself with José Ortega y Gasset's then influential theory of modernist art as arte nuevo. I examine Mariana Pineda in this context of heightened political tension and, paradoxically, of great popularity of Ortega's theory of autotelic art. Finally, I discuss Lorca's publication of a self-criticism letter in $A B C$, one of the leading right-wing newspapers of the time, in which he denied that his play contained implicit references to Primo de Rivera's contemporary dictatorship. This letter was published in October 12, 1927, the day of the premiere of the play in Madrid, and Lorca's apolitical stance, paired with a conservative aesthetic discourse (he rejected the idea of his play being an "avant-gardist work," Obras 359) made him the center of another controversy, this time led by the journal La Gaceta Literaria.

The second chapter, "Of Humans and Puppets," opens with a study of Lorca's participation in the Billy-Club Puppets project (1922-23), a Granada-based group that produced what I consider a typically 
modernist manifesto in defense of puppet theater. Second, I make a case for the centrality of Cervantes in Lorca's experimentation with puppets and comic theater. I refer, in particular, to the chapter of Master Pedro's ambulant show in Don Quixote (Part II, 26), as well as Cervantes's interludes, highly self-referential plays that foreground the artificiality of the fictional worlds that unfold before the spectators. Finally, I look at specific examples of Lorca's puppet theater throughout the 1920s. The corpus of texts is formed by Lorca's The Billy-Club Puppets and In the Frame of Don Cristóbal, as well as two pieces that he defined as 'farces' for actors, The Shoemaker's Prodigious Wife and The Love of Don Perlimplin and Belisa in the Garden.

After the experience of The Butterfly's Evil Spell in 1920, Lorca turned his attention to popular puppet theater, in particular the Andalusian figures known as cristobitas or cristobicas, to articulate a new theory and praxis of the stage. In 1922, in collaboration with the music composer Manuel de Falla, Lorca initiated a collaborative project that signaled the beginning of what would eventually constitute a life-long engagement with the tradition of the Billy-Club Puppets [Titeres de cachiporra]. In their family home in Granada, Lorca presented the cachiporra puppets to his sister Isabel on the occasion of the celebration of the Biblical Magi, in the feast of the Epiphany, on January 6. After the spectacle, one of his collaborators, José More Guarnido, published a two-installment piece that I interpret as a unified manifesto of the new theatrical praxis that Lorca attempted to produce by bringing puppets to stage life. A reading of Mora Guarnido's essay shows how Lorca's apparent archaist gesture converged, significantly, with contemporary discourses of theatrical modernism in Europe.

Lorca's "schematic" (Obras 219) technique of characterization, a term he used in 1932 to establish an evolutionary line running from Cervantes to Pirandello (Obras 218), is an aspect that traverses a group of four plays: The Billy-Club Puppets, In the Frame of Don Cristóbal, The Shoemaker's Prodigious Wife and The Love of Don Perlimplin and Belisa in the Garden. The evident similarities of motifs and plot schemes in both genres could even qualify these two streams as a single dramatic unity, very much in the same way that Lorca's three tragedies are grouped as a 'rural' trilogy (see Byrd "Puppet"; Gerling; Menarini "Gli anni"). In this chapter I discuss the baroque affiliation of this set of plays, an affiliation of intertextual nature that points to Cervantes's drama as its main source. I echo the opinion of Francisco García Lorca, Federico's brother, who explicitly referred to the episode of Master Pedro's retablo, in chapter 26 of Part II of Don Quixote, as the direct source for Lorca's own retablos (267). This typically baroque artifact of the ambulant puppet show challenges the notions of the static focal point and authorial authority by channeling multiple voices through the conflicting modes of mimesis and diegesis. I consider Lorca's two puppet 
plays (The Billy-Club Puppets, In the Frame of Don Cristóbal) as models for the two later 'farcical' or tragicomic dramas (The Shoemaker's Prodigious Wife, The Love of Don Perlimplin and Belisa in the Garden). What began as an open denouncement of the financial authority of theater impresarios, in the puppet plays, evolved into a more nuanced criticism against the constituting role of the audience in perpetuating certain moral codes on the theatrical stage, in The Shoemaker's Prodigious Wife and The Love of Don Perlimplin and Belisa in the Garden.

The third chapter, "Facing the Audience," is concerned with The Public, a play Lorca repeatedly described as the most ambitious of his dramas from his trip to New York and Cuba (1929-30) to his assassination in 1936. As noted earlier, in his late years Lorca was very explicit in defending his 'impossible theater' as the core of his theatrical reform. In an interview of 1936, after obtaining enormous commercial success with Blood Wedding and Yerma, he declared to have written theater according to "a well-defined trajectory ... My first plays are unperformable [irrepresentables] . . . It is in these impossible plays where my true purpose is. But, in order to prove my personality and obtain the audience's respect, I have staged other plays first" (Obras 631). Lorca was very aware of the fact that his contemporary audience would not accept the overt references to homosexuality in The Public. Three years before, in Argentina, Lorca had mentioned its manuscript but explained that "I don't intend to stage the play in Buenos Aires, nor in any other place, for I believe there is neither a company willing to perform it nor a public that could tolerate it without indignation" (Obras 444). When the journalist asked him about the reason of this impossibility, Lorca replied that it was because The Public "is the mirror of the audience... And because everyone's drama can be really painful, and generally it is far from honorable, spectators would immediately jump out of their seats, full of indignation, and they would prevent the performance to continue" (Obras 444). At work here is, once again, the $u r$-scene of a bunch of spectators interrupting a theatrical performance, experienced by the young Lorca in the premiere of The Butterfly's Evil Spell in 1920 and one that he then recreated in most of his plays of the 1920s.

As noted earlier, the only extant manuscript of The Public was in possession of Rafael Martínez Nadal, one of Lorca's friends, since 1936, and the Lorca estate did not authorize its publication until the mid-1970s. Two textual controversies have conditioned interpretations of this work since it became available to scholars: first, the widely accepted idea that one act is missing of what was supposed to be a six-act play; and, second, the controversy about a loose sheet of paper, containing a burlesque poem sang by the Foolish Shepherd [el pastor bobo], which Martínez Nadal inserted between the last two acts of the play. Acknowledging the obvious fact that there will not be an empirical resolution to these textual issues unless some kind of miraculous discovery of a 'complete' 
version of the manuscript takes place one day, I propose a reading that emphasizes Lorca's role as a modern archaist, someone who collected traces from the Spanish theater of the sixteenth and seventeenth centuries. This intertextual strategy allows for a new understanding of controversial aspects of The Public (for example, the Foolish Shepherd's song now stands out as prologue or introito, as Javier Huerta Calvo and Luis Trigueros-Ramos, the two last editors of the play, have signaled; moreover, the recurrent mentions that the characters in the play make to an unreachable sepulcher correlate with the baroque concept of the 'crypt,' developed by William Egginton).

In The Public, there is a distinction between 'theater in the open air' and 'theater beneath the sand' that comes out of the theoretical discussions between the Director and other characters in the play (the Three Men, the Four Students and, finally, the Prestidigitator). The differences between these two types of theater, as they are discussed by the fictional figures in The Public, have been routinely observed by Lorquian scholars since the book was published in the late 1970s. I propose an interpretation of Lorca's ideas of a new theater in light of the Spanish tradition of the auto sacramental. In The Public, Lorca redefines the stage as a liminal space existing between the suspension of disbelief typical of the theatrical event and the efficacy that is intrinsic to ritual. His experimentation with forms reminiscent of liturgical drama, in particular the auto sacramental, reconfigures the role of the theatrical institution in fostering a new relation between individual and community. Lorca's adoption of Calderón's allegorical drama did not happen in a historical void, of course. In 1927, he was partially involved in a production of Calderón's The Great Theatre of the World in his hometown of Granada, directed by university professor Antonio Gallego Burín. This was the first time an auto sacramental had been represented in Spain since this genre was banned in the eighteenth century. I argue that The Public, written in 1929-30, is the connecting link between Lorca's witnessing of the return of Calderón's allegorical theater, in 1927, and his hands-on experience at directing Calderón's auto Life Is a Dream with La Barraca in the early 1930s.

The fourth chapter, "Revolution in the Playhouse," is devoted to The Dream of Life, a work that synthesizes a model of didactic theater that Lorca developed in the last two years of his life (1935-36). Avoiding the stereotype of Lorca as an active socialist always prone to take contemporary politics to the stage, I discuss his constant refusal to participate in leftist and avant-gardist campaigns against the establishment during the three first years of the Second Republic (1931-34), an attitude in stark contrast with the one adopted by fellow members of the Residencia de Estudiantes circle, in particular Rafael Alberti. In October of 1934, a communist revolt in the northern region of Asturias occasioned a clash between the communist militias and the Spanish army. In reaction to 


\section{8}

these events, sympathizing with the Asturian rebels, Lorca wrote the first act and at least some scenes of a second act of The Dream of Life in the summer of 1935 (Rodrigo 290-2). His close contact with Xirgu, very active politically during the years of the Second Republic, also made Lorca more receptive to revolutionary discourses, in particular after reading his poetry and staging his plays before thousands of Catalan workers while accompanying Xirgu in late 1935. In January of 1936, he told the press that he had completed "a social drama ... that is interrupted by the audience and the people on the streets; a revolution takes place, and the theater is taken" (Obras 627), but the only manuscript that is left contains one single act. In 1992, Andrew Anderson changed the title of Lorca's Play Without a Title, renaming it as The Dream of Life [El sueño de la vida $]^{7}$ in light of the evidence contained in two interviews with Lorca published in Heraldo de Madrid newspaper in 1936 (see Anderson's essay "El Público"). Three years after Anderson, in 1995, Piero Menarini also advocated for a title change by invoking a newly found press article, published in the same newspaper, that referred to Lorca having almost completed "his social drama The Dream of Life" (qtd. in Menarini "El Público" 71-3). In perspective, the significance of Anderson and Menarini's amendment goes beyond a simple controversy on the right title of some kind of obscure manuscript. Rather differently, the research work of these two scholars shed light on Lorca's engagement with the theater of Shakespeare and Calderón. For a title such as The Dream of Life clearly establishes an intertextual connection to Shakespeare's $A$ Midsummer Night's Dream, precisely the play that the Director and his cast of actors are rehearsing when violence erupts inside the playhouse in Lorca's play. Besides establishing a clear connection with Shakespeare, the adoption of the title The Dream of Life also opens a second interpretive path, one that directs our attention to Lorca's interest in Calderón's allegorical drama. As it is well known, Lorca made Calderón's auto sacramental Life Is a Dream the first play to be staged by La Barraca in 1932, with Lorca playing the role of the Shadow himself.

In The Dream of Life the blood splatters the stage when a spectator steps onto the stage and shoots a factory worker who had dared to deny the existence of God. This explicit confrontation between authoritarian conservatism and leftist politics constitutes the most extreme instance of politicization in Lorca's theater. Lorca's desperate attempt to reconcile his inner anxieties with the cause of the proletariat ends up producing a dialectical exercise of difficult, or even impossible, resolution. Lorquian critics have struggled to deal with what they perceive as a political remainder in The Dream of Life, some sort of exterior layer that ruins what should be the essence of Lorca's drama (this aesthetic essence, of course, is understood in a Kantian sense, for the aesthetic value of the work of art seems contrary to the idea of "instruction" that Lorca wanted to institute). Lorca was well aware of this paradox and 
even foregrounded it from the very beginning of the play. In the opening speech, the Author addresses the audience with a lengthy discourse on the necessity of bringing 'reality' to the stage: "You'll probably say that this a sermon. And so what if it is? . . A sermon! Yes, a sermon! Why do we always have to go to the theatre to see what happens onstage and not what's happening to us" (Dream 94). Taking as the main theoretical reference Elinor Fuchs' The Death of Character, I adopt the term mysterium to refer to a modernist theatrical practice with a strong allegorical and didactic orientation that acquires relevance in the politically charged years of the interwar period, particularly in the late 1920s and the 1930s. This didactic strain of modernist theater adopted structural and symbolic patterns typical of the mystery play and religious drama and interpreted in reference to political or societal issues. Returning to The Dream of Life, a direct model for Lorca's play is Calderón's The Great Theater of the World. Calderóns's allegorical drama contains the rehearsal of the play Do Good, for God Is God and, once the rehearsal is over, the actors who have correctly interpreted their roles are called by the Author-God. I argue that Lorca's interest on the auto sacramental, as evidenced by the production of Calderón's Life Is a Dream in his years in La Barraca, was parallel with his own original interpretation of this allegorical tradition in the broader context of the modernist mysterium.

In "Writing for the Stage," the fifth and last chapter of this book, I revisit Lorca's Blood Wedding (written in 1932, premiered in 1933), Yerma (written and premiered in 1934) and his very last play, The House of Bernarda Alba (finished in the summer of 1936, premiered posthumously in 1945). Blood Wedding and Yerma represented the first two installments of the projected "trilogy of the Spanish land" (Obras 418), as Lorca put it in 1933, yet he eventually abandoned the idea and never discussed The House of Bernarda Alba in connection with the previous two plays. Despite the existence of structural and stylistic differences between Blood Wedding and Yerma, on the one hand, and The House of Bernarda Alba, on the other, I still operate with the idea that these three plays constituted a trilogy as they explicitly recreate patterns identifiable with the contemporary genre of the 'rural drama.' I thus situate the writing and staging of the agrarian tragedies in the immediate context of the Spanish theater industry of the early 1930s. Of special importance was the existence of the popular genre of 'rural drama,' whose conventions constituted both the starting point for Lorca, willing to stage his theater in commercial venues, and the background against which the originality of new "formula" (he used this term in an interview before the premiere of Blood Wedding in 1933, see Obras 411) was to be measured. Repeating the strategy that led him to write Mariana Pineda in emulation of Eduardo Marquina's drama histórico, Lorca composed Blood Wedding in 1932 well aware of the horizon of expectations set by the genre of 


\section{Introduction}

the drama rural, also mastered by Marquina. This genre had its origins in the regionalist dramas of José Felíu y Codina and Ángel Guimerá; in the last years of the nineteenth century, it was canonized as national culture when Jacinto Benavente staged The Lady of the House (1908) and The Unloved Woman (1913). Marquina obtained commercial and critical success with The Hermitage, the Fountain, and the River (1927) and The Hidden Fountain (1930), in both cases with Xirgu as the leading actress. Lorca's relationship with Marquina went beyond a partial imitation of his generic formula, as they co-directed Lorca's first agrarian play, Blood Wedding, premiered at the Teatro Beatriz of Madrid on March 8, 1933. In this chapter, I analyze in detail an extended preview feature of Blood Wedding in Sparta magazine in which Marquina, who had defended the establishment authors against the 'young,' represented by Alberti, back in 1931, now openly defined Lorca as the only 'new' playwright who could produce a true impact on the general audience of his time. Moreover, from a production standpoint, it is necessary to consider that rural dramas featured female roles tailored for actressmanagers who, like Josefina Díaz, Lola Membrives and Margarita Xirgu, worked with Lorca in the 1930s. Díaz and Membrives lead the first two productions of Blood Wedding, in 1933, in Madrid and Buenos Aires, respectively. After the success of Blood Wedding, Xirgu, who had staged Mariana Pineda (1927) and The Shoemaker's Prodigious Wife (1930) before, premiered Yerma (1934), Lorca's second agrarian play. Xirgu, who had been teaming up with director Rivas Cherif since 1930, also did a new production of Blood Wedding in Barcelona, in 1935, and, as noted earlier, posthumously premiered The House of Bernarda Alba in Buenos Aires in 1945. The dominance of actress-managers is an aspect that is necessary to keep in mind to understand what Delgado, in an excerpt quoted earlier, refers to as the "materials conditions" of Lorca's theater.

Besides rural drama, I argue that Lorca's agrarian plays maintain a close dialogue with seventeenth-century Spanish theater, in particular with Calderón. As the creator of Blood Wedding, Yerma and The House of Bernarda Alba, Lorca stood out as both an innovator and an archaist, very much in the same way that he was recognized for his adaptations of dramatic works by Cervantes, Lope de Vega and Calderón in his role of director of La Barraca. There are two specific aspects of the agrarian plays that can be looked through a Calderonian lens. First, Lorca's tendency to abstract characterization, especially in Blood Wedding and Yerma, acquires new meaning when studied in connection with Calderón's allegorical drama as opposed to his symbolist technique being considered an intrusion of Lorca the poet in the terrain of Lorca the playwright. As I show in this chapter, most theater reviewers subscribed to this second argument, and Lorca reacted to their critics by developing a theory of abstract characterization that evolved from an apology of 
"poetic fantasy" (Obras 412) in Blood Wedding to the explicit vindication of Calderón's allegorical techniques to formulate "embodied ideas" (Obras 612) in Yerma. Finally, I conclude this chapter with an analysis of the three agrarian plays as modern versions of baroque honor plays. By highlighting the importance of a baroque code of honor in the actions and behaviors of female figures (the Bride proudly displaying her virginity in the last scene of Blood Wedding; Yerma invoking her lineage when he rejects the simple idea of conceiving a child with a man other than her husband; Bernarda Alba's failed attempt to hold on to an honor value system as her dynasty crumbles) my aim is to read these plays beyond the many times repeated idea that they convey what is an essentially leftist, or even revolutionary, message. In questioning this aspect of the Lorca myth, I propose a dialogue with the previous work of scholars such as Linda Materna, Jesús García Maestro and Isaac Benabu.

This book identifies, and explains, the different directions of Lorca's theatrical production without resorting to a lineal description that implies some sort of 'natural' succession of stages in his art. Therefore, any statement about what came 'last' in his theater needs to be in parentheses, for here we are dealing with the uncertainties that are result of a life truncated too soon. The other route would be, of course, basking under the well-ordained Lorca myth, one that is always reassuring, or at least until one begins to experience the signs of exhaustion that Fernández Cifuentes already observed in the Lorquian academic community two decades ago. On a different plane, the textual controversies affecting the transmission and interpretation of many of his dramatic works are also a reason to partially depart from philological debates to focus instead on the artistic and social context in which Lorca was inserting himself by making very conscious decisions when writing a certain play and mapping out a strategy to see it staged. The consequence of this premise, as readers will notice, is that in tracing Lorca's trajectory in the Spanish theatrical industry from 1920 to 1936 I make a claim to situate it in dialogue with the contemporary practices of a whole range of social actors such as theater impresarios, newspaper theater critics, editors of literary journals and university professors, not to mention the mainstream playwrights whose artistic codes Lorca partially emulated, at times, in order to reach bigger audiences.

Two of Lorca's full-length plays fall outside the scope of my analysis: As Five Years Pass and Doña Rosita the Spinster. The first one is a surrealist play completed in 1931, clearly indebted to his New York experience, and that he eventually planned to stage in a small theater club in the fall of 1936. Its production was obviously interrupted by the outbreak of the Civil War and Lorca's subsequent assassination that summer of 1936. The second is a period play that he wrote for Xirgu in 1935, to capitalize on the success of Yerma. The Catalan actress staged Doña Rosita the Spinster in Barcelona in late 1935. They are not part 


\section{Introduction}

of the corpus of this book simply because they are works that did not propose a particular dialogue with the theatrical industry of the time. This methodological decision, needless to say, does not imply a value judgment.

As readers may have noticed, in referring to Lorca as an "archaist" in search of a "new" stage, I am paying homage to Yuri Tynianov, who in 1929 published the collection of essays Archaists and Innovators. His book opened up new vistas for twentieth-century literary theory, specifically in the subfield of the theory of literary history (Tynianov's collection features "The Literary Fact," "On Literary Evolution" and "Dostoyevsky and Gogol [Toward a Theory of Parody]," to name three of his essays).

\section{Notes}

1 See Andrew Anderson's introduction to his recent edition of Poeta en Nueva York, in particular 34-43, for more details on the editorial process that led to the publication of Lorca's book, concurrently with its English translation, in 1940 .

2 In his "Translator's Note," Humphries confessed the difficulty of facing a typescript that was "not always perfectly clear, and at times declaring its own confusion." He also explained that there were instances "when I have had to try to establish a text .... Lorca seems to have been a quick reviser, and there is no principle of objective epigraphical logic that the scholarby-necessity can apply to extremely subjective surrealist stuff" (qtd. in A. Anderson Introducción 43).

3 In his well-known essay "The Author as Producer," Walter Benjamin emphasizes the need to break away from the bourgeois notion of the writer as a specialist who inhabits the ineffectual territory of art while remaining ignorant of the interaction between his work and the general conditions of production.

4 In 1935, the first English translation of Blood Wedding, partially supervised by Lorca himself, had a run of 24 nights at the Lyceum Theatre in New York.

5 Rivas Cherif's project became a reality in 1933, when the government of the Second Republic supported his Teatro de Escuela de Arte, Spain's first modern theater school. The school closed in 1937 due to the Civil War, and never reopened.

6 Lorca had been holding private readings of The Public since returning to Spain in 1930 (Gibson 478). He intended to represent The Public as early as 1931, as noted in letter to his family in which he refers to contacts with the actress-manager Irene López Heredia (Obras 1182), and, contrary to his tradition of not giving his works to print, he published two acts of the play in the literary magazine Los cuatro vientos in 1933.

7 To date, Play Without a Title remains the only title available to readers in English, with the exception of John London's translation The Dream of Life. London's translation is included in his volume The Unknown Lorca, published in 1996. All quotations in this book are taken from London's text. 


\section{The Question of Allegory}

This chapter is devoted to the first two plays Lorca staged in commercial theaters, The Butterfly's Evil Spell and Mariana Pineda, premiered in 1920 and 1927, respectively. While Lorquian scholars have traditionally referred to Lorca's The Butterfly's Evil Spell as a "categorical failure" (Aszyk 262), or at best, an uneventful first experience, the truth is that the premiere was a full-fledged scandal due to the negative reaction of both critics and spectators to its symbolist patterns of characterization. This drama, mostly written in verse, portrays a story of impossible love between a stranded butterfly and the cockroach-turned-poet Curianito, yet critics in Lorca's time could not accept the gap existing between the literal and the symbolic. As two reviewers wrote, cockroaches could never "become poetic symbols" (Andrenio in La Época) and their presence on the stage only produced a "watered down and confusing allegory" (J.A. in El Sol). The night of the premiere of The Butterfly's Evil Spell, the Teatro Eslava of Madrid became a space of verbal and even physical confrontation between two differentiated audiences. On one side, there were spectators of conservative taste, sitting in the lower level seats and in the boxes; on the other side, there were dozens of young Lorca "supporters" [partidarios] who, according to the testimony of one his friends attending the premiere, constituted a vociferous crowd in the balcony seats and even exchanged fists with other members of the audience (Mora 127). One can argue that Lorca learned about the spatial dynamics of the playhouse the hard way.

As early as 1924, Lorca conceived Mariana Pineda as a way to rectify the sabotaged premiere of The Butterfly's Evil Spell. In dramatizing the final days of Mariana Pineda, a liberal heroine executed in 1831 for conspiring against the absolutist regime of King Ferdinand VII, Lorca voluntarily situated himself within the parameters of the contemporary genre of "historical drama," a subgenre of the teatro poético championed by Eduardo Marquina. From the time of its inception in 1924 to its premiere in Barcelona in June of 1927, Lorca insisted on discouraging political interpretations of Mariana Pineda to avoid potential problems with the military regime of Miguel Primo de Rivera (1923-30). Lorca resorted to different strategies, from aligning himself with José Ortega y 
Gasset's theory of autotelic art, early in the process of writing the play, to orchestrating an 'apolitical' press campaign when Mariana Pineda was staged in Madrid in October of 1927. Despite his efforts to control the reception of the play, however, in his return to the theatrical industry, Lorca found himself caught up in different controversies. When Mariana Pineda premiered in Barcelona, Lorca was criticized for basically being a bad copy of Marquina's model of historical drama. In Madrid, he received similar criticisms, and in addition, his play became object of discussion in the campaign against the theatrical establishment by the group around La Gaceta Literaria, the most influential avant-gardist literary journal of the late 1920s in Spain.

After a short-lived stint of four nights in the Teatro Eslava, Lorca distanced himself from The Butterfly's Evil Spell and did not submit a copy of it to the Spanish Registration Office, disregarding the two letters he received in the weeks following the premiere. ${ }^{1}$ Lorca's immediate rejection to document what constituted his first incursion in the theater industry significantly affected the material preservation and transmission of a dramatic text whose status is still as uncertain as that of his 'impossible' dramas The Public and The Dream of Life. Lorca's negative stance toward The Butterfly's Evil Spell, up until his death in 1936, however, is not the only factor that has been an obstacle for a comprehensive approach to this dramatic text. A major factor is the obvious existence of a significant gap between what is inscribed in the printed text and the information available about Martínez Sierra's production of the play in 1920.

Piero Menarini has reconstructed what happened in the period between December of 1919, when Martínez Sierra announced to Lorca his firm intention to stage the play, and its premiere on March 22, 1920. "It is evident," Menarini observes, "that something strange occurred" (Introduction 20) in these three months. The play title changed from The Minute Comedy [La infima comedia], the one that Lorca had chosen originally, to The Meadow's Star [La estrella del prado] and then, scarcely ten days before the premiere, to The Butterfly's Evil Spell. It is believed that Martínez Sierra made these title changes without Lorca's input. Moreover, while the extant manuscript contains a drama divided into two acts, testimonies from theater critics and spectators who attended the premiere suggest that there were originally three acts. Finally, Menarini observes, the playbill and the information contained in press reviews noted that there were characters on the stage that did not entirely correspond with the dramatis personae listed in Lorca's manuscript. These three significant changes were preceded by Martínez Sierra's decision to represent the play with human actors, contrary to Lorca's original plan, which was to stage it as a puppet play. ${ }^{2}$

What materially remains of The Butterfly's Evil Spell is an incomplete text. Menarini has recreated its missing final scene by merging a long stage direction, which he found in a separate sheet, with information 
inferred from testimonies from critics and general spectators who saw the play. As Lorquian critics are well aware, the mutilated condition of a dramatic text is the norm rather than the exception in Lorca's repertoire. Lorca only published two of the nine plays that he saw staged in his lifetime (Mariana Pineda, 1930; Blood Wedding, 1935), a number that evidences the partial importance he gave to the dramatic text in the comprehensive project of reform of the Spanish stage in which Lorca was involved through his various capacities as stage director, adapter, music composer and, occasionally, actor. His disdain toward textual fixation was, after all, constant throughout his whole artistic career. In a 1927 letter to poet Jorge Guillén, Lorca justified his reluctance to publish the poems of Gypsy Ballads, a book of poetry eventually published in 1928, arguing that he did not want to see "my poems dead forever ... I mean published" (Obras 941). Eight years later, in an interview with a Catalan journalist while visiting Barcelona in 1935, Lorca continued affirming the need of self-restraint before giving works to print too soon (Obras 606). Also in that year, Lorca had explained to Italian journalist Silvio D'Amico: "I don't write plays to be printed, I write them for the stage" (Obras 572). The troubled textual transmission of the manuscript of The Butterfly's Evil Spell, as well as the negative reception of its production, have caused the long-time categorization of this drama as "a minor work or, at best, as some sort of indeterminate juvenilia" (Menarini Introduction 45-6), only of interest to a reduced community of researchers. Miguel García-Posada's most recent and, allegedly, definitive edition of Lorca's collected works (1996-97) expels The Butterfly's Evil Spell from the second volume of the collection, "Theater," and confines it to the last volume, "Early Writings." Aligning himself with García-Posada, Gregorio Torres Nebrera conceptualizes The Butterfly's Evil Spell as the "crystallization" of a series of "youth efforts, mostly in unfinished form" ("Del teatro" 425). Resorting to the distinction between 'center' and 'periphery,' Torres continues to affirm that this is the work that "establishes the limit between [Lorca's] early incursions and his central works" [la obra central] ("Del teatro" 425). I interpret García-Posada's downgrading of The Butterfly's Evil Spell from 'true' theater to juvenilia not necessarily as a strictly personal and arbitrary move, but rather as a symptom of a collective discomfort toward its inorganic construction. To counter the view represented by García-Posada I now propose a detour from the 'organic' conceptions that tend to give preference to Lorca's 'finished' works while condemning to the margins dramatic works whose transmission has been affected by external factors. In the pages to follow I will first review Jan Mukařovský's idea of artistic intentionality and then I will proceed to apply it to specific aspects of The Butterfly's Evil Spell. Mukařovský's work is also helpful to conceptualize aspects of Lorca's later dramatic texts, whose transmission was also affected by numerous external factors. 
Mukařovský's familiarity with the theory and practice of the avantgarde of the 1920s and the 1930s explains his going beyond classical notions of totality and closure. A key term in his theoretical edifice is the partial neologism "soustavnost," a word that in everyday Czech means "consistency" or "steadiness" and only secondarily, in virtue of its etymology (soustava: "assemblage") signifies "arrangement" or, in the context of an aesthetic discussion, "structure" (Drábek 16). Mukařovský establishes a distinction between "holistic thought," which relies on the basic notion of "the closed whole," and structuralist thought, one that assumes "the interplay of forces [within the work of art], agreeing with and opposing one another, and restoring a disturbed equilibrium by a constantly repeated synthesis" ("Concept" 79). It is not a matter of a Gestalqualität that unifies all the components of a work under a closure-oriented principle, as is the case of verse in poetry ("Concept" 72-3). Rather differently, invoking the example of a sculpture of a torso, Mukařovský notes that as perceivers, we are still "confronting a whole, but here wholeness does not appear to us a closure, or completeness ... but rather as a certain correlation of components" ("Concept" 75). His definition of structure, "a stream of forces passing through time, constantly regrouping but uninterrupted" ("Concept" 79, his emphasis), is intrinsically tied to the idea of "function" ("Concept" 80), and anticipates what Jacques Derrida ${ }^{3}$ later proposed as an epistemological alternative to French structuralism in the 1960s.

Mukařovský adopts a phenomenological stance to art that liberates critics from the burden of authorial intention. It is through the duality of intentionality-unintentionality [zámèrnost-nezámérnost] that he brings to the foreground the central role of the perceiver in organizing the dominant forces inside the artistic work. Intentionality, understood as "the force which binds together the individual parts and components of a work into the unity that gives the work its meaning" ("Intentionality" 96), emerges as the default or non-marked option before the eyes of the beholder of the artwork. The observer will instinctively confront the artifact finding for "traces of an arrangement that will permit the work to be conceived as a semantic whole" ("Intentionality" 96). Mukařovský notes that the perceiver's initiative "provides the possibility that different perceivers (or rather different groups of perceivers) will invest the same work with a different intentionality, sometimes considerably divergent from that which its originator gave it" ("Intentionality" 98). This may get to the point, Mukařovský observes, that "those components which were originally outside the intention can even become vehicles of intentionality" ("Intentionality" 98-9). While Mukařovský acknowledges that the material construction of the artifact initially conditions the attitude of readers and spectators, he observes the existence of a historical variability to what perceivers may regard as intentional and non-intentional aspects of the same work of art. The consequence of this position is that 
something that was not intentional for the author can be integrated into the structure of the work of art as a part of its intentionality, always speaking here in phenomenological terms. Among the examples provided by Mukařovský, there appear those artifacts characterized by an "artlessness" due to a lack of technical skills (insufficient training to master the perspective in painting, language errors by authors who do not write in their primary language and so on) but are at one point interpreted as intentional by an interpretive community that sees in these "deviations" a new way to challenge the artistic rules of their era ("Intentionality" 104). The same can be said about strictly external factors caused by chance or material deterioration, the type of "accidental interventions that affect a work that is already finished" ("Intentionality" 105).

The intentionality/unintentionality dichotomy proves helpful in approaching the seemingly inarticulate nature of The Butterfly's Evil Spell. I will first address the question of the play's prologue, an independent scene that Lorca wrote after composing the two acts that constitute the 'main play.' It consists of a diegetic speech delivered by a character named Prologue who narrates the death of Curianito, a young cockroach who became the impractical and idealistic poet of a happy society of insects, and who suffered over an impossible love for a fallen Butterfly temporarily stranded in his world. Prologue claims to have heard the story from a sylph who escaped one of Shakespeare's books (Maleficio 88), an allusion that represents the first time that Lorca inserts in his dramas the motif of the randomness of love present in Shakespeare's A Midsummer Night's Dream (a central point of discussion in The Public, to be discussed in Chapter 3). C. Christopher Soufas interprets the prologue of The Butterfly's Evil Spell as evidence of Lorca's own awareness of lack of playwriting skills, a description that corresponds with Mukařovskýs concept of unintentionality. What transpires in the speech delivered by the Prologue is, according to Soufas, a feeling of "uneasiness" and "defensiveness," one that rather than encouraging the benevolence of the spectators ends up causing the opposite effect, a distancing of the audience that is "the ultimate consequence of making only an intellectual connection between the cockroach society and conventional reality" (26). My view is that the distancing effect Soufas complains against is actually a relatively common strategy employed by leading representatives of modernist drama from W. B. Yeats to Bertolt Brecht, as Martin Puchner has observed (Stage 18-28). In creating a character named Prologue that is external to the action he narrates, Lorca participates in what William Gruber, echoing Puchner's terminology, has conceptualized as a "fundamentally ... 'antitheatrical' strategy" consisting in the "the employment of narrative . . to distance the theatre from itself, to subvert mimesis, as it were, or to disable or displace it" (15).

Moreover, Soufas argues that the prologue scene of The Butterfly's Evil Spell was meant to somewhat externalize a work originally conceived as 
a closet drama, one that Lorca wrote "primarily for a private audience consisting only of himself" (27). This opinion is in tune with the one expressed by the many critics who rejected the play as 'non-theatrical' (more on this later in this chapter), and evidences a clear bias that sees the use of mimesis as something natural, in contrast to diegesis. Soufas' reaction to The Butterfly's Evil Spell consists in rejecting the prologue scene as a 'faulty' late addition to the play, a modification that he explains as an unintentional factor-Lorca's lack of playwriting skills at this point of his career. Contrary to his view, I interpret Lorca's prologue strategy as intentional given the fact that prologues and other types of intermediary discourses abound in Lorca's theatrical productions. The initial address to the audience in The Butterfly's Evil Spell reappears, for example, in The Shoemaker's Prodigious Wife, this time Lorca's alter ego demanding "attention" instead of asking for "benevolence," and eventually mutates into a tool of didactic theater in The Dream of Life. There are more examples of this practice: In the puppet play In the Frame of Don Cristóbal, the Director, the only role to be interpreted by an actor, delivers a prologue and then engages in constant quarrels with the puppets that refuse to follow the script he tries to impose on them; the scene of the wedding night in The Love of Don Perlimplin and Belisa in the Garden is interrupted by two sprites who cover the stage with a gray curtain to prevent us from witnessing Belisa's imminent adultery ("it is not fair to place before the eyes of the audience the misfortune of a good man," Love 116); and what resembles a plot in The Public is in great part the result of the weaving of a multiplicity of dialogues ${ }^{4}$ about the theory and praxis of a radically new theater 'beneath the sand,' not to mention Lorca's The Dream of Life, one that Reed Anderson defines as "in one sense a prologue that never ends; and in another sense ... a play that never begins" (213). Besides the prologue, another aspect of The Butterfly's Evil Spell that can be reconsidered in light of the intentionality/unintentionality dichotomy is its lyrical orientation. It is significant how in the fifteen years that extended from the night of the premiere of The Butterfly's Evil Spell up to the greatest success of his lifetime, Yerma, Lorca was recurrently accused of being incapable of reconciling the lyrical passages with the flow of dramatic action. Critics considered his style, once again, non-artistic, 'non-theatrical,' and therefore non-intentional, if we follow Mukařovský's terminology. In his review of The Butterfly's Evil Spell, for example, playwright and poet Manuel Machado criticized Lorca for "confusing lyric with dramatic poetry." Machado, one of the leading names of the teatro poético industry, accused Lorca of not realizing that "to put it in very simple terms, a little cockroach . . . cannot spend a long time reciting or listening to truly beautiful verses while nothing else is really going on besides the slow agony of the character, an agony that is very pathetic but hardly theatrical." Menarini partially justifies the lyrical construction of The Butterfly's Evil Spell, in particular the 
alleged disconnect existing between the characters' speeches and their movements, gestures and actions, by arguing that it is due to the fact that Lorca originally wrote the script as a puppet play (Introduction 47).

In the discussion of the alleged disconnect between lyricism and plot progression in The Butterfly's Evil Spell, the judgments expressed by Machado and, to a lesser extent Menarini, though separated by eight decades, are materializations of a single critical approach that relies on the concept of artistic unintentionality, particularly its aspect of insufficient writing skills, to account for Lorca's alleged compositional shortcomings. The problem with this approach is that it operates with fuzzy concepts that tend to reproduce a teleological, lineal reading of Lorca's trajectory in the theater, and that have solidified into undisputable truths. Interpreters of Lorca's work will never be able to determine the difference between a 'mistake' due to lack of skills and a visionary aesthetic gesture from Lorca, for example, and the same goes for the eternal discussion between text and spectacle (the difference between what Lorca 'intended' to mean when writing a script and what was effectively put on the stage, in many cases, to complicate things further, under his partial or total supervision). A biographical explanation may seem to work in application to The Butterfly's Evil Spell, but it is, at the most, a Pyrrhic victory that gets us in trouble in the long run because unintentionality cannot explain other instances of Lorca's work that shows the same patterns of lyricism and weak dramatic progression. If prestigious theater critic Andrenio dismissed Lorca's first play for being a representation that "reduces itself to an alternative recitation, by different characters from a long-winded lyrical fable, livened up by some gloomy musical numbers," the same case against Lorca's musical orientation could be made, for example, against The Shoemaker's Prodigious Wife, a play that Lorca had in mind as early as summer of 1924 (see his letter to Fernández Almagro, in Obras 809). Premiered in Madrid in 1930, right after returning to Spain from New York and Havana, The Shoemaker's Prodigious Wife is arguably the drama that is the hardest to judge today because the published text gives a very limited idea of what Lorca conceived as a total experience of artistic practices that involved multiple scenes of singing and dancing. The Shoemaker's Prodigious Wife complicates the notion of dramatic progression but, rather than escaping linearity of plot and well-rounded psychology by engaging in lyrical detours at least partially identifiable with Marquina's contemporary formula, it does so by exposing its condition of total spectacle. In admiration of the Spanish comedia, a spectacle that in the late sixteenth and seventeenth centuries encompassed music, dance and comic playlets (entremeses) in the intermissions and after the conclusion of the three-act main play, Lorca conceived The Shoemaker's Prodigious Wife as a "pantacomedia," (Obras 468), some sort of patchwork with dance and musical scenes whose relationship with the alleged main plot 
could not be ascertained by the critics. Fernández Cifuentes observes at this respect that in the 1920s Lorca adopted these archaic forms "without significant alterations" and, in the case of The Shoemaker's Prodigious Wife, dance, music and songs "seem to have retained their original complementary and disposable character" (García 146). What could be easily defined as an instance of immature use of artistic sources from a relatively young Lorca, however, becomes a more complex issue if we take into account that this gravitation toward the artificiality of the work of art is still evident in his critically and commercially acclaimed dramas of the Spanish land. As Fernández Cifuentes notes, in Blood Wedding "those minor and marginal forms behave like grafts that transform the larger drama, that polarize and subdue all the other elements from the center" (García 146). Finally, I want to raise the point that even a play like Yerma does not meet the 'organicist' standards that have been traditionally applied to The Butterfly's Evil Spell. The character of Yerma gravitates towards a single obsession, her behavior being unaffected by her interactions with rest of the figures, as I will discuss in Chapter 5. Moreover, had Yerma be judged with the same standards applied to The Butterfly's Evil Spell, it would have never been considered a masterpiece in light of the presence of 'non-theatrical' traits such as musicalized scenes and a general lack of dramatic progression. I am not, of course, proposing the removal of Yerma of the canon of twentieth-century Western drama. My aim is rather to expose the theoretical inconsistencies that derive from excessively relying on a teleological approach to Lorca's activities in the theater.

The premiere of The Butterfly's Evil Spell took place in Gregorio Martínez Sierra's Teatro Eslava on March 20, 1922. For a period of ten years (1916-26), Martínez Sierra's playhouse combined commercially successful plays with more experimental works outside realist drama and bourgeois comedies. He had first-hand knowledge of Catalan and French symbolist drama (Salaün 20-1); in addition, in the late 1910s and early 1920s, he was particularly interested in cross pollination between theater and non-linguistic forms such as pantomime and ballet. At the age of 21, therefore, Lorca had the opportunity to premiere a play in a prestigious venue just months after leaving Granada for Madrid with the original plan of establishing himself as an author and musician. He had arrived in Madrid in the spring of 1919 and thanks to his insistent networking efforts, he secured a position in the Residencia de Estudiantes for the 1919-20 academic year. After spending the summer of 1919 in Granada, he convinced his family to allow him to transfer from the University of Granada to the Central University of Madrid. Alberto Jiménez Fraud had founded the Residencia in 1910, adopting the British residential college model he had known in his visits to Oxford and Cambridge in preceding years. As is well known, from 1910 until the outbreak of the Spanish War in 1936, the Residencia hosted lectures by distinguished 
international guests from all fields of knowledge (Albert Einstein, Marie Curie, Le Corbusier, Henri Bergson, to name a few) while also becoming one of the musical centers of interwar Europe (Manuel de Falla, Igor Stravinsky and Maurice Ravel performed there). Lorca was very aware of the centrality of the Residencia in Madrid's cultural life, as evidenced not only by the quality of its lectures and recitals but also its editorial activities. ${ }^{5}$ From his early days in Madrid, Lorca saw relationship building as a key element of his artistic success. Paradoxically, the myth of Lorca as a poet who happened to write drama almost accidentally, without really being familiar with the mechanisms of the theater industry of his time, accompanied Lorca from 1920 practically until the end of his life in 1936. He first faced this accusation after the premiere of The Butterfly's Evil Spell, and this image of 'outsider' still haunted him when Blood Wedding and Yerma were taken to stage in 1933 and 1934, respectively. In stark contrast with this stereotype, however, the truth is that Lorca initiated his contacts with the leading names of the industry when he paid his first visit to Eduardo Marquina in the spring of 1919. In May of that year, Marquina took Lorca to the premiere of one of Jacinto Benavente's plays in the Teatro Lara (see Gibson 151-2). Benavente, leading figure of bourgeois drama, was then considered a serious contender for the Nobel Prize, an award he eventually received in 1922. With the help of modernist poet Juan Ramón Jiménez, Lorca first met Martínez Sierra and her partner and leading actress Catalina Bárcena during his first stay in Madrid, in the spring of 1919. In June of that year, back in Granada, Lorca had the opportunity to meet the couple again while they were touring Southern Spain. It was then that Martínez Sierra and Bárcena commissioned Lorca to write a play out of one of his poems that he had recited to the couple. This poem, never published, told the story of the ill-fated character Little Cockroach [Curianito] and his impossible love for a butterfly temporarily stranded in the world of the cockroaches. This story eventually became the plot of The Butterfly's Evil Spell. ${ }^{6}$

Melchor Fernández Almagro collected the details of the production of The Butterfly's Evil Spell in "The First Premiere of Federico García Lorca," a 2-page piece for the ABC newspaper in $1952 .{ }^{7}$ Thirty-two years after the premiere of The Butterfly's Evil Spell, Fernández Almagro remembered Lorca's debut as an unavoidable clash against a "hostile" (19) crowd. He described Lorca as an "avant-gardist" [adelantado], somebody "ahead of his time . . . leading the cause for a new theater" (19) with The Butterfly's Evil Spell, a symbol of the "battle" (19) between old and new views on Spanish theater. The exceptional condition of The Butterfly's Evil Spell among the horizon of expectations of his time explains its hostile reception despite the financial effort on the part of Martínez Sierra (the production featured two star actresses, Bárcena and La Argentinita, as well as music, décor and costume design arranged by three respected collaborators of Martínez Sierra). On March 23, 1920, 
the day after its premiere, the reviewer for El Liberal lamented that the play lacked "emotion, interest, action, visual power," yet observed that "the audience should have been a little more respectful." In El Debate, the reviewer complained about the "excessive severity" of the spectators, blaming them for making it almost impossible to hear the verbal exchanges. In tune with these two anonymous reviewers, Francisco Aznar Navarro provided a vivid picture of the night's events in La Libertad:

It was a miracle that a grave conflict didn't break out in Martínez Sierra's theater last night. The spectators, divided in two factions ... began to chide each other (there was someone in the upper seats who delivered a speech but was interrupted by noisy protests), and it didn't take much for it to turn into a fist-fight.

As noted earlier, The Butterfly's Evil Spell only ran for four nights, and Lorca's first incursion in the arena of commercial theater resulted in a failure that kept him outside the theatrical circles for seven years, until he staged Mariana Pineda in 1927. The verbal and physical violence that spoiled his debut in the playhouse remained in his memory, to the point that Lorca's most political play, The Dream of Life (1935) consists of the dramatization of a conflict between spectators and a theatrical cast. This play features interruptions, political speeches and even the killing of one the actors by a spectator identified with the fascist party. I interpret the traumatic experience of The Butterfly's Evil Spell as some kind of $u r$-scene that haunted Lorca for years.

The question of the alleged excess of lyricism in Lorca's first play needs to be discussed in connection with its very explicit symbolic undertones. If by 'symbolic' one means 'symbolist,' then Lorca's first play easily stands out as a symbolist drama in the stage tradition of Paul Fort's Théâtre d'Art and Lugné-Poe's Théâtre de l'CEuvre, two theaters that Martínez Sierra had known in the early years of the century. In this regard, it is significant how some of the reviewers focused their criticism not on the young author but on Martínez Sierra himself, for allegedly abandoning a national theatrical tradition in favor of the foreign aesthetics of French symbolist drama (see, for example, Alejandro Miquis' argument in his review in El Universal). More generally, in terms that are not theater-specific, The Butterfly's Evil Spell can also be conceptualized as 'symbolic' art in light of its condition of standing for something else, since there is an evident distance between the literal and a dimension of meaning to be perceived as symbolic or allegorical. In his review for La Época newspaper, Andrenio had trouble accepting the idea that cockroaches could be "transformed into poetic symbols" and defined the play as a "diluted and confusing allegory." Positioning himself against a mise-en-scène that attenuated the physical traits individualizing the stage figures, he concluded that "allegory and symbolism 
of true poetic value" should be inscribed in the plot itself and never be the visible result of the actors wearing "artificial costumes." Taking this critique to a new rhetorical level, an anonymous reviewer at Hoy sardonically applauded the "calf contest of the actresses, dressed as cockroaches." What these attacks had in common was a feeling of unpleasantness produced by the darkening of what was expected to be a transparent relationship between performing subjects and dramatic characters. Or, to put it in Jiří Veltruský's terms, what occurred was that the individual stage figures typical of realistic theater became attenuated when they were integrated into a wider set of insect figures virtually indistinguishable among them. The concept of 'stage figure' ${ }^{8}$ helps to explain the prevalence of narration/recitation over dramatic presentation in symbolist drama. Veltruský notes how, in privileging lyric over dramatic texts, the symbolist playwrights "were aware of the fact that the productions of their texts would entail a drastic attenuation of the crucial position held, since the Renaissance, by the dramatis persona conjured up by the actor" ("Semiotics" 89). The two photographs of the production of The Butterfly's Evil Spell that were reproduced in $A B C$ newspaper showed the extent to which the similarity of the costumes reinforced the depersonalization of the bodies on stage.

There is little doubt that Martínez Sierra's penchant for French symbolist theater was one of the central forces driving the production of The Butterfly's Evil Spell. Thanks to Fernández Almagro, Gibson and Menarini, Lorquian scholars now have access to a number of historical materials that help to better understand the nuances of the 1920 production. These findings on the performance history of The Butterfly's Evil Spell are not incompatible with an analysis of its dramatic text, even if what Menarini has rescued is an incomplete manuscript. In this regard, I still claim the agency of Lorca as author of this dramatic text, in particular to what concerns the decision of creating a world populated by a bunch of insects. Lorca was exploring a very personal allegorical mode of writing in the years immediately preceding his first play. Between 1918 and 1920, he authored the monodrama Theater of Souls (1918) as well as numerous religious-philosophical dialogues inspired in his early readings of Plato, among these The Primitive Auto Sentimental (1917), Of Love. Theater of Animals (1919) and the more irreverent and even carnivalesque Shadows (1920), whose working title was, in a very Platonic fashion, The Final Banquet. This experimentation with allegorical prose and animal fables was obviously one of the main reasons why Lorca made his theatrical debut with the insect play The Butterfly's Evil Spell. While the symbolist influences of Martínez Sierra's mise-en-scène of The Butterfly's Evil Spell are obvious, a look at the dramatic texts needs to also take into account Lorca's allegorical gesture when creating a fictional world populated by insects with human-like passions, urges and weaknesses. 


\section{4}

The Question of Allegory

Seven years after the experience of The Butterfly's Evil Spell, Lorca had a second chance to confront the audience when his play Mariana Pineda was staged in Barcelona and Madrid in June and October of 1927, respectively. This was a text that Lorca had ready for the stage since early 1925, and that he initially conceived as the work that would secure him a relevant role in the Spanish theater scene, more specifically in Madrid, where he initially hoped to premiere it (Obras 828). Lorca's letters from 1924 to 1927 evidence his increasing frustration with what he perceived as a marginal role as producer of commodities in a context dominated by impresarios and star actresses. Throughout the process of taking Mariana Pineda to stage, Lorca acquired an education about the financial aspects of the theater industry. He viewed Mariana Pineda as a way to rectify the failed premiere of The Butterfly's Evil Spell, and at first he was very optimistic about Martínez Sierra's involvement in an upcoming production the play. In 1924, Lorca considered Mariana Pineda finished, and in a letter from late that year, he announced to this family that Martínez Sierra was fully convinced of the commercial success of the play (Obras 818). In commercial terms, it was the perfect blend, the result of merging a historical theme suitable for large audiences in Madrid and Barcelona with the idealized image of nineteenth-century Granada that romantic writers had created and perpetuated for decades. The big problem that Lorca was facing at this point was the obvious existence of a political surplus in the play, due to Mariana's identification with the history of Spanish liberalism. In this letter from late 1924, he explained to this family that rehearsals were being postponed because of the current political instability. Even if the government of Primo de Rivera allowed its performance, "a scandal would erupt in the theater, and they would close it, leading to the impresario's ruin, which nobody wants." (Obras 819). In this letter, Lorca insisted on defining Mariana Pineda as "a work of pure art, a tragedy made by myself, as you know, with no political interests, and I want its success to be a poetic success-and it will be! It will be performed when it gets performed" (Obras 819, his emphasis). To prevent political interpretations of this play, Lorca adopted and reproduced Ortega y Gasset's contemporary theory of dehumanized art, very influential among students of the Residencia in the months previous to its publication in book form in 1925. Ortega's poetics conceived fiction as an autonomous realm detached from the praxis of life. In Ideas about the Novel, published in a single volume together with The Dehumanization of Art, he resorted to different concepts ("contemplation," "hermeticism," "imaginary psychology") that in their essence are not but variations of the idea of autonomy just mentioned. His vocabulary was a rewriting of the Kantian notion of art as an experience of disinterested pleasure, an activity free from practical implications. 
The prospects for Mariana Pineda looked bleaker in 1926, after what Lorca interpreted as a continuous lack of commitment from Martínez Sierra as well as from other personalities of the Spanish stage that had promised him support in his new theatrical venture. In his letters to family and friends, Lorca became very critical with the establishment. Disappointed at Martínez Sierra, and after approaching three different star actresses (Carmen Moragas, Margarita Xirgu, Lola Membrives), Lorca wrote to his family in a letter of April 1926: "Dealing with impresarios is the most repugnant thing in the world because they are all beasts. Spanish theater is today in the hands of the worst people, and I'm talking about actors as well and authors" (Obras 893). In his letters from 1926 and early 1927, Lorca showed little hope to see Mariana Pineda, not to mention The Shoemakers's Prodigious Wife, staged. When reporting his talks with the big names of the theater industry, he regularly referred to profit prospects as the central issue in discussion. After three years contacting different theater companies, and mostly thanks to Marquina's mediation, ${ }^{9}$ Lorca finally received confirmation from the Catalan actress-impresario Margarita Xirgu in early 1927. Xirgu's plan was to premiere the play in Barcelona in the summer and then take it to Madrid, to open the 1927-28 theatrical season in October. At this time, however, Lorca was openly expressing his loss of interest in the play. "I do not like this work [Mariana Pineda] at all, you know it" (Obras 943), he wrote to Fernández Almagro in January. In a letter from February, to Jorge Guillén, Lorca explains that "I extraordinarily liked making a romantic drama three years ago. Now I see it at the margin of my work" (Obras 957). Yet in March, he met Xirgu and discussed arrangements for the rehearsals of the Barcelona production. Despite his lack of directorial experience, and Xirgu's artistic and financial authority as a well-established actress-manager, Lorca insisted on overseeing the rehearsals. In order to obtain money to travel to and stay in Barcelona several weeks, Lorca reached out to his parents in Granada and eventually convinced them of the importance of him directing Xirgu: "If this doesn't seem fine, I am inclined to march to Granada and let Xirgu do the play as she pleases, with the decorations and the declamatory delivery however she may like it" (Obras 986). Mariana Pineda constituted Lorca's return to the industry as a playwright protected by Xirgu, and at the same time, this production was also his first incursion at directing in the arena of commercial theater.

Besides an increasing awareness of his dependence of economic interests, there is a second aspect that is worth examining when considering Lorca's overall strategy to gain a reputation as playwright and stage director in these educational years of 1924 to 1927. I am referring to his conscious alignment with Marquina, the greatest authority of the so-called teatro poético in Spain, a genre of immense popularity at the time. Marquina took to perfection a model also cultivated by Francisco Villaespesa 
and Antonio and Manuel Machado. Theirs was a drama written in verse that primarily fell into two categories, historical and rural plays, and that departed from realism by often depicting decadent, exotic landscapes in a postromantic fashion. Carefully weighing all the pragmatic factors necessary to stage Mariana Pineda with commercial success, Lorca sought Marquina's explicit endorsement in order to gain access to the impresarios and star actresses who dominated the contemporary theatrical scene. Lorca's letters from 1924 to 1926 contain multiple references to Marquina's mediation with the industry, first in thankful terms and later, in 1926, in a rather negative light for what he felt it was a cynical stance from the famed playwright. However, what makes the Lorca-Marquina relationship contradictory is not the personal anecdote, but the fact that in composing the final text of Mariana Pineda Lorca voluntarily situated himself within the conservative conventions of Marquina's dramatic language. This was not an isolated event in Lorca's career. In February of 1927, Marquina had obtained a resounding commercial and critical success with his rural tragedy The Hermitage, the Fountain, and the River, staged in the Teatro Fontalba of Madrid. This play featured a love triangle in a small village dominated by what critics described as a world of "primitive" passions and "repressed sensuality." ${ }^{10}$ Xirgu played Deseada, the leading role. Marquina's was one of many rural dramas that flourished in the Madrid stage in these years, a commercially successful subgenre that prefigured Lorca's rural tragedies of the 1930s. Xirgu staged Mariana Pineda in the Teatro Fontalba of Madrid in late 1927, and there is no doubt that the intertextual connection was clear to those spectators who had witnessed her impersonation of Deseada, the femme fatale who eventually commits suicide in Marquina's play, in the same playhouse a few months earlier that year.

Lorca's letters contain very specific references to the making of his play Mariana Pineda from 1923 to 1927. In a letter dated from May 1923, Lorca informed his family that he had compiled "two versions of the ballad of Mariana Pineda" (Obras 726). In the same month, he contacted University of Granada professor Antonio Gallego Burín to request biographical information on the local figure of Mariana Pineda, announcing to him his intention to take to stage "a great theatrical ballad" (Obras 768) for which he already had the characters thought out. A few months later, in September, Lorca found himself in a position to summarize the aesthetic principles of Mariana Pineda in a letter to Fernández Almagro:

I want to create a stationary drama ... a simple and hieratic narration, surrounded by mysterious breeze, as an old madonna with her cherubs' bow. A kind of stylized version of the medieval ballads sung by blind storytellers [una especie de cartelón de ciego estilizado]. (Obras 785, his emphasis) 
What transpires from this 1923 letters is Lorca's intention to situate himself within a tradition of popular literature and folklore that sees the life and death of Pineda almost as a myth of oral transmission. In the 1920 s, on the verge of the centennial of her execution in 1831 at the age of 26, the figure of Mariana Pineda was appealing to Spanish theater audiences. Mariana Pineda, who despite her young age had participated in liberal plots against the reactionary monarch for years, was formally charged of embroidering a liberal flag with the words "Freedom, Equality, Justice" and executed by the authorities of Granada following King Ferdinand's repression against constitutionalist rebels. A dramatic plot based on Mariana Pineda's life had the typical elements of melodrama, her being a woman in love who refused to betray one of the leaders of a liberal revolt against the king. A part of her popularity was also due to the gruesome details surrounding her martyrdom. She was subjected to garrote vil, her neck strangled by a tightened iron collar, and in this respect Robert G. Havard has observed the "baroque" nature of the spectators' fascination with a figure whose beauty "is brutalized, violated and mangled by one of the most chilling and barbaric forms of capital punishment ... inlaid upon her exquisite feminine tenderness is the presentiment of the horror that is done to her" (3). It is no coincidence that Lorca's play contains numerous, and contradictory, allusions to Mariana's neck, which evolves from Petrarchan motif (his lover Don Pedro: "your lovely moonlight neck aglow," Mariana 103), to locus of masculine violence (police officer Pedrosa: "my hands have the power to squeeze your neck," Mariana 133) and, in the third and last act, to symbol of religious transcendence (Second Novice: "Her neck is pure as dawn!," Mariana 163).

Immediately following King Ferdinand's demise in 1836, Mariana's body was exhumed from a common grave to be buried in the Nuestra Señora de las Angustias Church of Granada. An annual procession showcasing her reliquary urn around the city of Granada was instituted, and held for two decades, until a final transportation of her remains from the Angustias to the crypt of the Cathedral of Granada took place in 1856. This series of transportations of Mariana Pineda's remains and reburial(s) was of course controlled and documented by the Catholic Church. In the very same year of 1836, the first biography of Mariana Pineda also came out, with enormous success. However, despite the abundance of vivid details, Lorca declared himself not interested in pursuing a historically accurate reconstruction of Mariana's life and death, neither was his intention to portray Mariana as a political heroine. Rather differently, in a 1923 letter to Fernández Almagro, Lorca described his Mariana as a character madly in love who is accidentally trapped in a political world. Mariana Pineda is

possessed, a case of magnificent Andalusian love in an extremely political environment ... She submits herself to love for love, while 
the others are obsessed with Liberty. She ends up a martyr of Liberty, being in reality ... a victim of her own heart, enamored and maddened. (Obras 785, his emphasis)

As noted earlier, a biography ${ }^{11}$ of Mariana Pineda's last days came out immediately after Fernando VII left power in 1836. In this early years, theater became the privileged artistic form in the very quick process of popularization of Mariana's figure. Fernando Nieto's allegorical play Anniversary of the Death of Doña Mariana Pineda, written in 1835, was performed as part of the first funeral procession in 1836. Moreover, two interconnected plays were published in Lisbon and Málaga, in 1837 and 1838, respectively. The first one was Francisco Villanueva y Madrid's The Heroism of a Lady, or the Tyranny of Her Force, a political drama full of overt attacks against the Catholic Church. The second, Francisco de Paula Lasso de la Vega's Mariana Pineda, gravitates more toward the love story between Mariana and Captain Sotomayor, and according to Menarini, it was clearly the blueprint of Lorca's version even though there is no empirical proof that Lorca read this text ("Mariana" 73n3). Lorca's idea of Mariana as a character whose passion, rather than political commitment, eventually drives her to her death, is very much in agreement with Lasso de la Vega's plot design. It has been demonstrated that Lorca consulted the 1836 biography of Mariana and that he omitted relevant information on Mariana's actual involvement in political activities, such as the fact that she had been under house arrest in the early 1820s (Havard 11).

Mariana Pineda premiered at the Teatro Goya of Barcelona on June 24,1927 , and received a positive response from critics and spectators. Unfortunately for Lorca, the play only ran ten nights due to Xirgu's summer break in July. Several critics praised its dramatic construction and even Lorca's psychological characterization of Mariana. However, reviewers at Diario de Barcelona and El Noticiero Universal objected to Lorca's inward approach to the figure of Mariana. The Diario de Barcelona critic lamented that Mariana's figure "shrinks . . . becoming more human, more common."12 Adopting a more critical stance toward Mariana Pineda, the leading Catalan newspaper La Vanguardia portrayed Lorca as "a careful and sentimental poet" rather than a creator of dramatic characters. In agreement with the opinion of the Madrid critics who had condemned The Butterfly's Evil Spell in 1920, the critic at La Vanguardia objected to the lack of cohesion of Lorca's new play, while still praising it for the "beauty" of "some poetic scenes that can be taken from the whole." After Barcelona, Mariana Pineda was staged at the Teatro Fontalba of Madrid on October 12, 1927, in the opening day of the 1927-28 theatrical season. That same day, Lorca's "Self-Criticism" [Autocritica] appeared in $A B C$. The 'autocritica' genre was the perfect vehicle for authors to comment on their works and influence their 
reception on the day of the premiere. Lorca, aware of the objections received in Barcelona, defended her inward portrayal of Mariana, explaining that his intention was not to produce an "epic drama" but rather create a "lyric, simple and popular" (Obras 359) version of Mariana. Lorca also claimed to have worked within the realm of the "legendary," as opposed to the "historical," inserting himself in an oral tradition that goes back to the Mariana ballads of the mid-nineteenth century. Lorca's self-critique also evidenced his concern about the reception of Mariana Pineda in the Madrid avant-gardist circles, for Lorca was well aware of the distance between Marquina's drama histórico, the backdrop for Mariana Pineda, and the theory and practice of the new art in Madrid. To prevent a critical backlash, Lorca actualized the military terminology to define Mariana Pineda not as an example of "avant-garde" but rather "a work of sappers [gastadores]" (Obras 359), the sappers being the soldiers whose primarily function is to excavate trenches.

The Madrid critics that were closer to Lorca praised the organic unity of Mariana Pineda (see reviews in La Voz, El Sol y La Nación, for example) and even defined the play as a great success ("resounding," "victorious," "unanimous" were three terms that appeared in their reviews). This initial impact, however, did not translate into a commercial victory. On October 18, four days after the premiere of Mariana Pineda, Xirgu wrote to playwright Joaquín Muntaner to communicate her intention to stage one of his titles in substitution of Mariana Pineda. Lorca's play, Xirgu confessed to Muntaner, “doesn't work” (qtd. in Balcells 197). Mariana Pineda went on for a total of twenty-six nights in Madrid, and was not successful when it toured several Spanish cities in the following months. Returning to the critics' reaction to the play, the truth is that Lorca's lyric portrayal of Mariana Pineda only convinced one sector of the press. On October 18, Andrenio published an adverse analysis of the Madrid production with the title of "The Ghosts of History." In this text, Andrenio attacked Lorca's "lyricism" for producing the "substitution of the historical physiognomy of the character for a kind of astral body." Andrenio also accused Lorca of taking the easy route by indulging himself in "the ghosts of capricious inventive" without conducting what Andrenio believed was the necessary process of research and documentation prior to writing a historical play. This Madrid-based critic published "The Ghosts of History" in the Barcelona newspaper La Vanguardia. Four days later, on October 22, Fabián Vidal wrote a second review of Mariana Pineda also for La Vanguardia. Vidal accused Lorca of making use of "invention," "fantasy" and "artifice," resorting to a partially obscure language that catered to "selecte minorities." He also criticized Lorca for not presenting a more faithful rendition of actions for which Mariana Pineda became a heroine for generations of Andalusians and Spaniards. In 1923-24, when planning his second attempt to triumph in the theatrical industry, Lorca had thought that the laws 
of the teatro histórico genre would guarantee him successful access to the contemporary stage; however, once Mariana Pineda made its debut in Barcelona and Madrid in 1927, part of the negative responses to this play was due precisely for what was perceived as an insufficient adhesion to the rules of the genre. Lorca minimized the presence of scenes that would demonstrate Mariana' political courage, and all her exchanges with male figures, be they her young suitor Fernando or the cruel police officer Pedrosa, are driven by her blind allegiance to the rebel Pedro de Sotomayor, a fictional figure created by Lorca precisely to reinforce the play's melodramatic plot. The fact that all actions take place in interior spaces (Mariana's house in Acts I and II; her cell in the convent-turned prison where she awaits her execution center in Act III) is also indicative of Lorca's will to depart from the realm of 'official' history.

By the time Mariana Pineda arrived in Madrid, Lorca had spent several years involved in the activities of the Residencia artists, as a close friend of Salvador Dalí and, to a lesser extent, Luis Buñuel, as well as part of the circle of poets later recognized as the Generation of '27. Parallel to his engagement with the aesthetics of the Spanish avantgarde, Lorca had laid out an intense campaign of networking with commercially successful playwrights, theater managers and actressesimpresarios, adopting an aesthetic stance that was in stark contrast with his daring drawings and poems. Unlike in Barcelona, where his public figure was less known, Lorca had a difficult time conciliating his two separate identities of poet and playwright when Xirgu brought Mariana Pineda to Madrid.

What was common to The Butterfly's Evil Spell and Mariana Pineda is that when these two plays were produced Lorca found himself caught in different crossfires. Critics hostile to Martínez Sierra received The Butterfly's Evil Spell as an imitation of French symbolism that went against the Spanish theatrical canon. Mariana Pineda was first a dangerous text because of its potentially revolutionary content; when it finally premiered in 1927, Lorca was accused of downgrading a national icon and of presenting a deformed version of Marquina's historical drama. I will conclude this chapter with a discussion of the role of Mariana Pineda in a controversy about avant-gardist aesthetics and its relationship with politics among avant-gardist artists in Madrid. I have already mentioned Lorca's travel to Barcelona to oversee the rehearsals of Xirgu's company as an attempt to control the play's mise-en-scène, and the timely publication of his "Autocritica" in $A B C$ the day Mariana Pineda premiered in Madrid. These are two of many strategies that Lorca put in play in an effort to influence its production and reception. A look at the final version of the text, for example, reveals Lorca's reliance on stage directions to compensate for his deliberate adoption of romantic clichés. The stage directions describe the two melodramatic exchanges that Mariana has with her suitor Fernando (Act I) and the four liberal conspirators 
(Act II) as "an engraving typical of the period" (Mariana 65) and "an attractive engraving" (Mariana 107), respectively. These stage directions suggest a degree of self-awareness on the side of the actors, who are expected to pose as if compounding a lithograph. Another example is the first appearance of villain Pedrosa, which takes place in Act II, when he abruptly breaks into Mariana's house on a rainy night. He is first defined as "thoroughly dislikable" but Lorca rapidly warns that "it is important to avoid caricature" (Mariana 125). Finally, it is worth noting how stage directions in climactic scenes incorporate numerous references to the use of silence on stage, as if prescribing a symbolist rendering of the text that significantly differs from the quick tempo that audiences would associate with a play about political conspiracies. Moving away from the text and focusing on details of the actual production, Salvador Dali's design of one smaller frame within the general stage frame corresponded with Lorca's plan to create a (mild) cognitive distance between stage and spectators. Lorca gladly accepted Dalí's scenographic solution since this two-layered design was in consonance with his own design of a play that is framed by a prologue that features children singing the ballad of Mariana Pineda in the streets of Granada. This initial frame corresponds to the 1850s, with a temporal distance of two decades after her execution. It can be concluded, in short, that Lorca imagined a sober representation of Mariana Pineda that would escape both the perils of romantic clichés and the didactic orientation of patriotic drama. By emphasizing the artificiality of his play, constructing a theatricalist frame to defuse the melodramatic clichés, he expected his work would be tolerated by his fellow avant-garde writers and critics in Madrid.

The importance of Mariana Pineda became evident as early as October 15, 1927, only three days after its debut in the Teatro Fontalba of Madrid. On this day, the Heraldo de Madrid published a long interview with Lorca in which he defended himself from his critics and elaborated on several aspects already contained in his "Autocritica." The same day, La Gaceta Literaria, the most influential avant-gardist literary journal of the late-1920s, published a very sharp analysis of the play by novelist and critic Francisco Ayala. In the interview, Lorca hinted for the first time at the baroque models of his theater. As in his "Autocritica," Lorca rejected the term "vanguardista" (Obras 363), but this time he performed an archaist gesture that invoked Félix Lope de Vega's dramatic construction ${ }^{13}$ and Luis de Góngora's verbal inventive as the two models he intends to emulate in the near future (Obras 362).

As noted earlier, Mariana Pineda had an acceptable run of 26 nights in the Teatro Fontalba of Madrid, in Lorca's first collaboration with Xirgu. The main problem that he was facing at this point was finding a way to align his theatrical production with the theoretical discourse of avant-gardist circles in late 1920s' Spain. It is in this context of negotiation of a new public identity that I want to bring into discussion 
Francisco Ayala's open defense of Lorca in La Gaceta Literaria. Ayala highlighted the existence of a subtle "ironic pattern" in Mariana Pineda that "produces a distancing effect on the audience, making the play unfold as it if were an old engraving." What Ayala described as a strategy of "intentional ingenuity" and "artificial infantilism" allows Lorca to "actualize romanticism" while at the same time maintaining it at distance. In claiming the contemporaneity of Mariana Pineda, Ayala went even further to the point of explaining Lorca's approach through Ortega's theory of dehumanized, modernist art. "Romanticism [in Mariana Pineda] is an object, a theme, filtered through a cold lens. A lens that is, to a point, dehumanizing," he noted. One aspect I find of great importance is how Ayala described Xirgu's acting work as inadequate for the play, in particular when it came to representing Mariana's quasimystical experience in jail, surrounded by a chorus of nuns. Ayala noted that a "more sober approach [from Xirgu] would have been desirable" in this third and last act, and he also accuses her of rendering a "realistic interpretation" and an "unacceptable humanization" of the figure of Mariana Pineda.

Once again without Lorca's being able to fully control the situation, the production of Mariana Pineda triggered a discussion that ended up representing the generational divide that young authors, in very avantgardist fashion, were trying to create to differentiate themselves from their immediate predecessors. In La Gaceta Literaria, Ayala had celebrated the "truly unusual event that is a young, avant-gardist poet being vehemently applauded by a theatrical audience," yet in the following issue of the journal (Nov. 1), surrealist author Ramón de Basterra defined Mariana Pineda as a "swallow's stool" [defecación de golondrina], precisely in a conversation with Ayala himself. In between the two issues, on October 22, La Gaceta Literaria had organized a banquet to celebrate "the triumph of Lorca's drama" (see the brief chronicle "Homenaje," also in the Nov. 1 issue), but the reality was that the sixty personalities in attendance had no unanimous opinion on the value of Lorca's play. As a typical avant-gardist provocateur, Ernesto Giménez Caballero, editor of La Gaceta Literaria, asked the guests to stand up and speak out against Lorca's play. The only one who accepted the challenge was Ramón Gómez de la Serna, who sardonically identified himself as the only spectator of Mariana Pineda (most of those present had really not seen it, according to the author of the chronicle). De la Serna praised the play for showing "freedom, a lot of freedom, a lot of freedom." This ironic attitude toward Mariana Pineda evidenced Lorca's difficulties in obtaining a full adhesion from the avant-gardist circles of Madrid. In its following issue, of November 15, La Gaceta Literaria initiated the publication of the "Spanish Youth Poll" series, a questionnaire designed to make the great names of the 1920s (Gómez de la Serna, Antonio Espina, Benjamín Jarnés, Ayala, etc.) weigh on the relationship of politics and literature. 
According to a brief anonymous note accompanying the chronicle of the October banquet, the controversy in this banquet had made evident the "need to elucidate what separates, politically, our generation from the previous ones" (see full text in "Una encuesta"). Mariana Pineda, in short, signified Lorca's entrance in the circuit of commercial theaters, as well as the beginning of his collaboration with Xirgu, but it happened at the cost of being object of attack by self-identified avant-gardist artists in Madrid.

\section{Notes}

1 The Sociedad de Autores Españoles requested a copy of the text of The Butterfly's Evil Spell in April 1920, one month after its premiere. In Appendix I of his critical edition of Lorca's play, Menarini reproduces a second letter sent to Lorca in July of that year, a letter from Rogelio Escalante, interim director of the Sociedad (214).

2 See Menarini Introduction 20-36 for an extended discussion on all the last-minute changes that affected the production of The Butterfly's Evil Spell.

3 In his essay "Structure, Sign, and Play in the Discourse of the Human Sciences," Derrida conceives of the text as one with no center, no "fixed locus but a function, a sort of nonlocus in which an infinite number of signsubstitutions came into play" (280). In his critique of Levi-Strauss' structuralist model, Derrida argues that the French ethnographer still operates within an empiricist paradigm when he implicitly accepts that his work can be corrected or invalidated by new empirical data (288).

4 About The Public, Wright observes that "has no prologue, but comprises a dialogue within the plot between the Director and the other characters, thereby rendering the whole play a form of prologue or liminal space" (Trickster-Function 14).

5 In late 1919, the Residencia had already published volumes by Antonio Machado, Miguel de Unamuno and José Ortega y Gasset. In 1923, Ortega y Gasset launched Revista de Occidente.

6 Martínez Sierra had staged Shakespeare's A Midsummer Night's Dream in 1918 and 1919. See page 445 in Dougherty and Vilches La escena madrileña entre 1918.

7 Fernández Almagro's was the first extended piece on Lorca's theater published by $A B C$ since the end of the Spanish Civil War in 1939.

8 Otakar Zich's Aesthetics of Dramatic Art (1931), a theoretical treaty almost unknown to international theater researchers, contains the first conceptualization of the idea of stage figure [herecká postava, literally "figure of the actor"], a concept later expanded upon and revised by Veltruský. The Sausserean duality signifier/signified cannot account for the constructive role of the audience in the perception of the gap existing between the actors and the dramatic characters they enact. Zich develops a three-part model by adding the intermediary concept of the stage figure. Zich explains that "the figure is what the actor makes, the character what the audience sees and hears," which means that "the stage figure is a formation of the physiological kind, the dramatic character a formation of the psychological kind" (qtd. in Quinn 77). Until recent years, Zich's idea of stage figure had not caught the attention of theater semioticians, with the aforementioned exception of Veltruský. This oblivion is not surprising if we consider that 


\section{The Question of Allegory}

Zich's trichotomy was not even popular among Prague scholars. In his retrospective essay "The Prague School Theory of Theatre," published in the late 1970s, Veltruský observes: "Most of the theoreticians belonging to the Prague Linguistic Circle were reluctant to adopt this concept of the stage figure as distinct from both the actor and the character" (232).

9 Lorca's efforts to recruit Marquina in his effort to reach out to Xirgu are documented in a number of his letters from 1926 (see Obras 893, 896, 906-7, 924, 928).

10 See original quotations on page 161 of Dougherty and Vilches' La escena madrileña entre 1918.

11 The first biographical account of Mariana's life was written by José de la Peña y Aguayo, who had fathered Mariana's third child in 1829. She had become a widow at the age of 18 , in 1822 .

12 See excerpts of reviews of Mariana Pineda published in Barcelona newspapers in Fernández Cifuentes García 45.

13 Lorca's Mariana Pineda has an intertextual connection to Lope de Vega's The Knight of Olmedo (1620), a play that was, same as Lorca's piece, a dramatization of a legendary ballad. In Mariana Pineda, the ballad of Ronda in Act I, and the ballad that narrates the treacherous murder of liberal hero Torrijos in Act II, constitute two creative rewritings of key scenes in The Knight of Olmedo. (Compare verses "Que de noche lo mataron ...." in Lope de Vega's play, with the ballad of Torrijos "Muy de noche lo mataron ..." in Mariana Pineda.) 


\section{Of Human and Puppets}

After the negative experience of The Butterfly's Evil Spell in 1920, Lorca turned his attention to popular puppet theater, in particular the Andalusian figures known as cristobitas or cristobicas, to rethink the theatrical stage from both a theoretical and practical standpoint. The first section of this chapter is concerned with Lorca's role in the collective project of the Billy-Club Puppets [Titeres de Cachiporra] in 1922-23. In collaboration with composer Manuel de Falla, designer Hermenegildo Lanz and cultural critic José Mora Guarnido, Lorca developed a collaborative project that materialized in a momentous performance on January 6, 1923, in Lorca's family house. This soiree was followed by a manifesto in defense of puppet theater published in the Spanish press the same month of January. The second section of this chapter makes a case for the centrality of Cervantes in Lorca's writing of plays for both puppets and human performers. It is by interpreting Cervantes how Lorca first defined himself as inheritor of the tradition of Spanish baroque drama. Because of the importance of Cervantes, I consider it necessary to make explicit discursive strategies in The Man Who Pretended to Be from Biscay and The Marvelous Puppet Show, two of his highly self-referential short plays, as well as the chapter of Master Pedro's traveling show, included in Part II of Don Quixote. Finally, with Cervantes as background, I look at how Lorca problematized the stage-spectators axis in his puppet plays The Billy-Club Puppets and In the Frame of Don Cristóbal, as well as his 'farces' for humans The Shoemaker's Prodigious Wife and The Love of Don Perlimplin and Belisa in the Garden.

Menarini distinguishes two phases in Lorca's writing of puppet theater. He traces Lorca's earliest interest in puppet theater back to late 1919, when he began working on a puppet play that Martínez Sierra forced him to rewrite as the symbolist play that eventually received the title of The Butterfly's Evil Spell, as noted in the preceding chapter. This first period finishes approximately in 1926, when Menarini estimates Lorca completed what is considered the final version of his The Billy-Club Puppets ("Gli anni" 141). The second phase of high writing activity goes from 1934 to 1936, when Lorca revised and completed In the Frame of Don Cristóbal to have it staged in Buenos Aires in 
March of 1934, and upon his return to Spain on several occasions in Madrid in 1934-35, using partially different versions of the text (Menarini "Federico" 120-3). The apparent lapse that extends for eight years (1926-34) was not a real hiatus in Lorca's engagement with the art of puppetry, since he made repeated efforts to stage The Billy-Club Puppets, first as a single-standing play in Madrid (see letters to his family from May and June, 1928, Obras 1060-1), and later paired with The Love of Don Perlimplin and Belisa in the Garden. Lorca entertained this second idea while in New York, in 1929, convinced that "it would not be difficult" to stage these two plays in English translation thanks to the existence of what he defined as "an avant-garde theater circuit" in the city (Obras 1145).

The strict distinction between puppet plays and what Lorca referred to as 'farces' for actors has been object of debate among Lorquian scholars for decades. Menarini observes that puppets are rather a constant in Lorca's overall trajectory in the theater, to the point that they represent "a genre that runs parallel" to the rest of his dramatic production while evidencing a notorious "resistance" to its assimilation to the illusionist conventions of theater for actors ("Gli anni" 141). On the other hand, however, because Lorca thought of puppet theater as a modeling source for his tragicomic pieces for actors, it was not unusual for him to refer to both artistic paths with the same generic distinctions. In 1924, Lorca wrote to Fernández Almagro that he has finished the first act of The Shoemaker's Prodigious Wife, a play he defined "in the style" (Obras 809) of the cristobicas puppets. Ten years later, on March 25, 1934, The Billy-Club Puppets premiered in Argentina with the subtitle of "Lace-paper valentine inspired in the old and shameless Andalusian puppet show," a variation of the subtitle "erotic lace-paper valentine" ["aleluya erótica"] that Lorca had chosen for The Love of Don Perlimplin and Belisa in the Garden upon its completion in 1929. Lorca's original intention for the world premiere of The Billy-Club Puppets was, similarly to the idea he had in New York five years earlier, to pair it with a puppet version of The Love of Don Perlimplin and Belisa in the Garden, as he expressed to his family in a letter written just a month before the premiere in Buenos Aires (Obras 1256). Guillermo de Torre, the first critic who took on the task of collecting Lorca's texts, in 1938, referred to this group of plays as "farces transplanted from the world of wooden toys into the world of characters of flesh and blood" (18).

Lorca's puppet plays have been traditionally relegated to the category of 'minor works' due to the simplicity of the plots to be enacted by the popular cristobicas. This labeling of his work has routinely invoked episodes of Lorca's childhood (his first encounter with a traveling theater company in the town of Fuente Vaqueros, the marionette theater his mother brought him from the city of Granada and so on), to somehow downgrade this popular art in contrast to his 'major' theater epitomized 
by his three agrarian tragedies. John Brotherton notes in this respect how the frequent mentions of Lorca's engagement with puppets early in his life seem to imply that puppetry "is essentially the child's province, and so, referring to it within the context of Lorca's infancy makes it fit neatly into the biographical schemes of things. The reader is led to suppose that Lorca will graduate to the 'adult' theatre of live actors" ("Promiscuous" 385). In light of similarities of motifs and plot schemes in the four plays mentioned above-the point of departure is always the young, unsatisfied wife who is married to an older, typically passive man-David R. Gerling argues for the consideration of the streams of puppet theater and human farces as part of a single dramatic unity, very much in the same way that Lorca's three tragedies are grouped as a 'rural' trilogy (151). Gerling studies the textual chronology of these plays mentioned above and concludes that The Love of Don Perlimplin and Belisa in the Garden represent a "masterful synthesis" (152) of Lorca's farcical iterations. In addition to the obvious thematic commonalities among the four plays, I approach them as instances of what Lorca defined as "the most schematic farce" (Obras 218), one directly evolving out of Cervantes' drama, as Lorca put it in a speech to the authorities of the Second Republic that was held in the Central University of Madrid in October of 1932. In this speech, Lorca made an explicit connection between Cervantes and Pirandello (Obras 218).

A second cause of the distortion of the image of Lorca's involvement with puppets is the result of a combination of factors such as the existence of different versions of his puppet plays and the uncertainty of dates that would clearly indicate the beginnings and ends of each project. This also exposes the inadequacy of the modern, post romantic idea of originality to his writing for puppets. For the fact that Lorca freely borrowed from the popular culture of Andalusia and Spain-traveling puppet shows, traditional music, ballads, comic strips-poses a difficulty when it comes to applying modern ideas on originality, authorship and genius to his cristobicas series, a diverse group of puppet plays featuring the violent male figure of Don Cristóbal. In accordance to the nature of folk theater, the texts of Lorca's puppet plays were subject to alterations and revisions that were dependent on the specific configurations of space and audience in each performance. Petr Bogatyrev's observation on how plot in folk theater constitutes a mere "foundation" (qtd. in Veltruský "Structure" 146) for improvisations that affect not only the actor's delivery (gestures, intonation, etc.), but also the preexisting text itself, applies to Lorca's writing for puppets. This is the case of the text of In the Frame of Cristóbal prepared for the Buenos Aires premiere, one that includes Argentinian regionalisms and contains a syncopated syntax in imitation of avant-gardist poetry of Oliverio Girondo and Pablo Neruda. Girondo and Neruda, as well as other authors and theater critics who were present in the playhouse, were playfully teased by the puppet Don Cristóbal 
following the script prepared by Lorca. When Lorca staged the puppet play in Madrid months later, in January of 1935, he removed all explicit mentions to his Buenos Aires audience and also stripped the text of traces of Rioplatense Spanish. Moreover, Mario Hernández explains, Lorca exercised "self-censorship" (Introduction El retablillo 16) and suppressed a number of corporeal references aware of the fact that it was to be represented at the Lyceum Women's Club, a very different venue with a different spectatorship.

In the nineteenth century, puppet theater had been synonymous with low culture, a practice mainly associated with such marginal spaces as the fairground and, often coupled with commedia dell'arte spectacles, the boulevard and the marketplace. By the turn of the century, however, the artificial figure of the puppet was seen as the perfect metaphor for the whole paradigm of theater itself, when a comprehensive reform of the bourgeois institution of theater became a central concern of playwrights and directors alike. Puppets and marionettes were central to the critical discourse of symbolist drama, as dramatists and critics distrusted the ability of the actors to enact fictional roles. In this context, the actors' physicality was seen as an obstacle to the integrity of the work of art. In the time span that goes from Maurice Maeterlinck's first symbolist productions in the early 1890s to Vsevolod Meyerhold's theory and practice of the grotesque in The Fairground Booth (he staged Alexander Blok's play in 1906 and wrote an essay with the same title in 1912), a varied range of contributions revolved around the notion of the actor as puppet or marionette: Alfred Jarry's Ubu Roi (1896), originally conceived as a puppet play; Stéphane Mallarmé's penchant for puppetry and later closet drama and Edward Gordon Craig's famous theorization of the über-marionette in 1907. Around 1890, the French symbolists turned to the marionette and the puppet as the perfect instruments to achieve what Elinor Fuchs defines as the "de-individualization in favor of the Idea," a radical reform against the notion of "character as represented by the living actor" (29). Because the actor's body ceased to be seen as a positive (or, at least, neutral) signifier, the symbolist aversion to bodied spaces lead to the massive presence of puppets in dramas that revisited the allegorical patterns of medieval mysteries. ${ }^{1}$ The symbolist idea of the actor as a puppet/marionette became an integral part of the theoretical discourse of the directors who questioned mimetic aesthetics during the early years of the twentieth century. Craig, one of the first directors to propose an explicit comparison between actors and marionettes, affirmed that acting is not an art because actors cannot exercise a total control of their body. In accordance with the symbolist tradition, but also echoing Heinrich von Kleist's visionary essay "On the Puppet Theater" (1810), Craig declared that the actor's work "is of an accidental nature. The actions of the actor's body, the expression of his face, the sounds of his voice, all are at the mercy of the winds of his emotions" (55-6). Craig's formulation of 
the actor as $\ddot{u} b e r$-marionette aimed to replace naturalistic acting and settings by an abstract presentation of shapes and colors in which the human body would appear as one of the constitutive elements of theatrical art, but not necessarily the dominant one.

In a letter from December 1922, Lorca invited Fernández Almagro to the upcoming spectacle of an "extraordinary guignol" with musical instrumentation by Falla, a musical puppet theater which contained "tenderness and grotesque twists" (Obras 751) at the same time. In their family home in Granada, Lorca presented the cachiporra puppets to his sister Isabel on the occasion of the celebration of the Biblical Magi, in the feast of the Epiphany, on January 6. Lorca's first experimentation with the cristobicas, puppets with big wooden heads that made them resistant to rough physical action, was an exercise of cultural archeology tout court. The program featured The Girl Who Waters the Basil, and the Inquisitive Prince, a popular tale dramatized by Lorca for the occasion; the interlude The Two Talkers, attributed to Cervantes; and the twelfth-century Mistery Play of the Three Wise Kings [Auto de los Reyes Magos], considered the oldest dramatic text in the Spanish tradition. As a spectacle rooted in the circularity of the Christian calendar, the cachiporra show anticipated the cyclical patterns of death and regeneration that were to become the backbone of the folkloric forms that Lorca would later rearrange in his puppet plays The Billy-Club Puppets and In the Frame of Don Cristóbal. ${ }^{2}$ The locus of the representation, an arrangement of interior rooms in the house of the Lorca family in Granada, resembled the intimate spaces of modernist chamber theaters throughout Europe. Finally, the audience that attended the event, a hybrid body of one hundred children and adults, was not typical in commercial playhouses, a fact that in some cases has made Lorquian scholars regard this 1923 spectacle as a simple kind of entertainment for children not worth discussing in the context of Lorca's overall dramatic career. This exclusionist stance obviates the factors listed above, and denies an aspect as important as the relationship that Lorca established with the younger spectators by repeatedly addressing them through the cristobicas puppets, thus breaking the illusionist fourth wall and producing what constituted his first practical attempt of producing a new spatial dynamics in the theater. Moreover, from the standpoint of textual production, this puppet show signaled the start of an intense period of dramatic writing. Lorca's correspondence through 1923 contains the first references to multiple projects that would later materialize in late 1920s and early 1930s, from The Billy-Club Puppets to different plays written for actors.

As Menarini notes, Lorca envisioned his first incursion as author and director of puppet theater as the initial act of a collaborative, "longterm project" ("Federico" 109) that was supposed to ultimately give way to a company, the Billy-Club Andalusian Theater [Teatro Cachiporra 
Andaluz], to resurrect the tradition of the "Spanish Puppets" [Titeres Españoles]. Lorca's correspondence ${ }^{3}$ from the summer of 1923 includes mentions of a second project with puppets and silhouettes, again involving Lanz and Falla, for the upcoming fall, but this plan never materialized. From a theoretical standpoint, however, the crucial information on the scope of Lorca's first engagement with puppets is to be found in the two texts that Mora Guarnido wrote for the Madrid-based newspaper $L a$ Voz immediately following this puppet performance. In his role as cultural correspondent in Granada, Mora Guarnido published the chronicle "The Andalusian Cachiporra Theater" in two consecutive weekly installments, on January 12 and 19. Mora Guarnido demonstrated his first-hand knowledge of the cachiporra project. As Menarini observes, Mora Guarnido's occasional use of the "we," and the fact that he makes specific references to a future project only existent in Lorca's head, is a clear evidence of his direct involvement in this collective inter-artistic project lead by Lorca ("Federico" 109). I interpret Mora Guarnido's back-to-back texts as a unified manifesto, one split in two pieces for purely external reasons, of the new theatrical praxis that Lorca attempted to produce by bringing puppets to stage life. Mora Guarnido's installments remain understudied and, to the extent of my knowledge, no scholar has studied them in relation to contemporary debates in modernist drama. A close reading of Mora Guarnido's two theoretical pieces reveals the extent to which Lorca's apparent archaist gesture converges, significantly, with contemporary discourses of theatrical modernism in Europe. In the first part of this manifesto, Mora Guarnido defines Lorca's revival of the Andalusian cachiporra theater as a form "as new as ... a cubist poem" (his emphasis), one only accessible to the "select minority" that witnessed the spectacle in the Lorcas' house. The presence of the ideology of early cultural modernism, in defense of minority taste, is visible here. Mora Guarnido then goes on to enumerate the different aspects of Lorca's program for a renovation of the Spanish stage. Mora Guarnido hails the puppet Cristobica and his billy-club as the central figure of an art form that is "more expressive and human perhaps that even the theater of actors." He highlights the contrast between puppets and human actors to criticize the state of the "failed" theatrical industry of Spain, "a failure for which directors and actors are both to be held responsible," declaring that all those who witnessed Lorca's "first try at puppet theater" could appreciate "that the invariable gesture and the fast movements of the puppets produce deeper emotions than the affected gesticulations and movements of actors and actresses." In this first installment, Mora Guarnido also makes an argument of historical nature that first claims the precedent of Cervantes' Master Pedro's puppet show, while also linking the rudimentary psychology of the puppet figures to the patterns of characterization in Spanish baroque drama, in particular the entremeses genre. Mora Guarnido 
thus established, as early as 1923, the historical-theoretical ground for Lorca's later experimentation with farces that blurred the boundaries between human actors and artificial figures.

In the second part of his manifesto, published on January 19 with the slightly different title of "The Cachiporra Theater of Andalusia," Mora Guarnido emphasizes again the intimate nature of the cachiporra spectacle, a kind of "theater for small rooms ... for a select minority." He then proceeds to fully articulate Lorca's theory of the dramatic character, one that results of the intersection of a specific national tradition, Spanish baroque drama, with a variety of discourses around European modernism that embrace the marionette and the puppet. Mora Guarnido explains how characters in Spanish classic theater resemble "implausible puppets" [muñecos inverosimiles] "who act, talk, endure their greatest perils and [eventually] die with the solemn certainty of their being puppets." This apology of puppets as 'theatrical' or 'theatricalist' figures anticipates Lionel Abel's notion of 'metatheater', articulated in 1963 in discussion of the works of Shakespeare, Cervantes and Calderón. Unlike the catharsis-oriented Greek tragedy, the dramatic hero in the plays of these authors, Abel posits, is "conscious of the part he himself plays in constructing the drama that unfolds around him" (167). Moreover, Mora Guarnido interprets these self-conscious puppets as a remnant of the primitive origins of theater. In this second installment of his text on the cachiporra puppets, Mora Guarnido affirms that theater originated as stories enacted by artificial figures and that only later it evolved to the "mask" that made possible human acting for audiences in larger spaces. As Gordon Craig, who had a deep interest in masks of past civilizations, Mora Guarnido warns that illusionism could never attain the "perfection" of the "artificial and capricious" art form that is puppetry. Mora Guarnido concludes warning the reader about how

useless is to envision a fully natural and human theater, to strip the characters of all their puppet appearance; it is possible, inversely, to confer human virtues to the puppet without depriving it from being a puppet. The latter procedure seems to us the most loyal and sincere, and the most theatrical. This was the one adopted by Federico García Lorca. (his emphasis)

To establish a connection between Lorca's early involvement in the revival of the cachiporra puppets, on the one hand, and his writing of puppet plays and tragicomic plays for live actors, on the other, I will now refer to certain aspects of Cervantes' short plays (entremeses) as the source for the set of four Lorquian plays to be discussed later in this chapter. I will also claim the importance of the chapter of Master Pedro's ambulant show in Don Quixote (Part II, 26) as a model that Lorca closely followed in his dramatic production. I am thinking, in particular, 


\section{2}

of the mixing of actors and puppets, the joint use of mimesis and diegesis, and the blurring of the theatrical frame as three structural elements borrowed from Cervantes.

Radical changes took place in the Spanish theater industry in the decades that followed Cervantes' early experiences in the theater, first as spectator of Lope de Rueda's pasos, embryonic forms of professional theater, in the $1560 \mathrm{~s}$, and later as author of classicist tragedies taken to the stage in the early 1580 s. Of crucial importance was the institutionalization of the acting profession and the creation of the first permanent playhouses in Madrid in 1579 and 1583, playhouses owned by brotherhoods that destined a share of their profits to hospitals. Cervantes gave to print his collection Eight Comedies and Eight Interludes in 1615, one year before his death, after several failed attempts to have them staged in the late years of his life. A common denominator of this collection is the pervasive presence of discourses of a social and moral nature that intersect with the recently sanctioned 'profession' of acting. His interlude The Man who Pretended to be from Biscay, for example, opens with a dialogue of two prostitutes that reveals opposing views on the ethical implications of the act of standing for somebody else in everyday life. In The Marvelous Puppet Show, the most popular interlude in the collection, it is not by coincidence that the hoaxer Chanfalla legitimizes his fraudulent theater show by introducing himself to the local authorities in the audience as an actor-manager "summoned to Madrid to raise money for the hospitals with my performances ... They're counting on me to save them from the ruin" (100). The frontier between the 'outside' and the 'inside' of these dramatic texts never staged in Cervantes' life is tenuous. Framing the sixteen dramatic texts in the collection there is a prologue that reveals, in a transparent manner, Cervantes' awareness of his marginal position as a playwright not admitted into the business of the comedia nueva. ${ }^{4}$ It is my view that Cervantes' criticism against the commodification of theater, now subject to what he saw as the taste of ignorant public [vulgo] that applauded Lope de Vega's ruling model, constituted a direct influence on Lorca when it came to develop a rhetorical strategy against commercialism.

As if sharing with Cervantes a nostalgia for Lope de Rueda's itinerant theater troupes of the mid-sixteenth century, Lorca toured rural Spain with La Barraca from 1932 to 1935. In his role as director of this state-subsidized traveling theater company, Lorca staged three of Cervantes' interludes (The Careful Guard, The Divorce Court Judge and The Marvelous Puppet Show), plus The Two Talkers, a play then attributed to Cervantes that had been part of the program of the $c a$ chiporra puppets in 1923, as indicated earlier. It is significant that in The Marvelous Puppet Show hoaxers Chirinos and Chanfalla set their scam with the only help of very basic stage accessories, relying on narration to stimulate the imagination of the spectators who expected 
to see more sophisticated theater tricks in action in the first place. Then they deceive their audience of wealthy peasants by exposing the artificial (fictional) nature of the notion of purity of blood that passes as real in Lope de Vega's plays, a move that William Egginton defines as a classic example of a "minor strategy" that forces the commoners "to confront the reality that their honor is nothing but a play they are putting on one for another . . . their honor is treated like the fantasy scenario it really is" ("Baroque" 147). Lorca closely reproduces this scheme in The Shoemaker's Prodigious Wife when the Shoemaker returns home in the disguise of a puppeteer who, relying exclusively on diegetic means, gets his improvised audience to fully engage in the fictional reconstruction of his past with his wife despite the obvious falsification that is taking place. The Shoemaker's Wife herself is indeed the first one who willingly participates in the creation of this ulterior fantasy landscape, a behavior that only strengthens the comic nature of the play, as I will comment on later in this chapter. A second example of Cervantes' critical strategy is visible in his interlude The Man who Pretended to be from Biscay, also part of his collection of unstaged plays. The very title of this interlude would have immediately activated the comic expectations of the spectators that Cervantes never had, for the figure of the Biscayan is one of the oldest in the repertoire of interlude characters. ${ }^{5}$ The action in The Man who Pretended to be from Biscay revolves around a simple man who is fooled by two prostitutes with the complicity of a friend of his. Following traditional depictions of this stock character, Cervantes' Biscayan seems incapable of telling the difference between a real gold chain and a counterfeit one. A second distinctive feature of the Biscayan is his inarticulate language, unintelligible to the prostitutes. In this interlude, however, the character's speech consists in a syntactically altered Spanish rather than the comic dialect typically associated with this dramatic type. Therefore, instead of simply embracing the comic type, Cervantes foregrounds its conventionality by presenting not a 'real' Biscayan-'real' as the type stipulates, not as actual Biscayans are-but a trickster enacting this role. Only at the end of the interlude, when the prostitutes realize that they are the ones being hoaxed, the real identity of the (doubly) fake Biscayan is unveiled. "Do you notice how clearly our Biscayan friend is speaking?" (90), says one of the women, while the deceptive Biscayan responds to her that "I only garble my words when it suits me" (90).

The presence of the verb "unveil" in the paragraph above is not accidental. In The Man who Pretended to be from Biscay, the motif of the veil functions as a magnetic field attracting contradictory views on the act of standing for somebody else in theater or in everyday lifethe boundaries between these two realms are not necessarily clear. This tension is already visible in the dialogue of the two women at the beginning of the interlude. They are discussing a 1611 law that restricted 
the privilege of riding a coach to aristocrat ladies, on the condition that they do not cover their faces with veils. The official aim of this law, promulgated when Cervantes was writing his plays and interludes, was to preserve the status of the aristocrats when an emerging middle-class began to enjoy their privileges. But the law was also a response against a very specific situation, namely the increasing presence of veiled prostitutes in the coaches. In consequence, this law against deception, as I would put it, related deceptive practices to immoral behavior. One aspect of particular interest in Cervantes' interlude is how different the prostitutes' reactions to the ban are. Brígida, the first woman who learns about the news, laments that "No sooner do we scrounge a bit of power than they clip our wings and take it away from us" (80). She praises the transformative power of social disguise: "God rest my soul, I swear to you that every time I got my hands on a coach and took charge, I was so carried away I really thought I was someone important" (81). Very differently, her friend Cristina conceives the suppression of the mask as a happy return to authenticity, an authenticity that can only be defined by the acknowledgment of the artifice. Her words can be read as an apology of anti-illusionism in life and theater because, as she declares, "Since it's quite clear what's on offer, no one can complain that he's been deceived!" (81). Brígida and Cristina embody two opposing views on theater: while the former enjoys the act of enacting someone else's personality, the latter openly advocates for the suppression of illusion in the name of truthfulness.

Instead of restricting himself to a comic plot that exclusively relies on the Biscayan, Cervantes foregrounds the act of impersonating a character-or, adopting a term that was a neologism in his time, the act of interpreting a character. Cervantes wrote this interlude in the early years of the 1600s, when the notion that actors should imitate reality in a 'natural' way was relatively widespread throughout Europe. As Evangelina Rodríguez Cuadros has argued (325-31), it was at the end of the sixteenth century when the actor began to be recognized as somebody who masters the ars of appropriate expressivity (decorum), in contrast to the derogatory status of the old figure of the histrion. It was in this context of transition and assimilation that Cervantes reflected on acting. Nicholas Spadaccini and Jenaro Talens note that Cervantes's interludes offered "the possibility of questioning critically the very subjects that the comedia and the non-Cervantine entremés mask, not only through generic conventions, but also through the illusion-making devices of the theater and the ideological exigencies of the public stage" (29).

In October of 1932, recently named director of La Barraca, Lorca introduced Life Is a Dream, one of Calderón's autos sacramentales, to an audience formed by national political authorities at the Central University of Madrid. Lorca famously declared that "the pendulum of Spanish theater oscillates violently between the antagonistic worlds of Calderón 
and Cervantes" (Obras 218). Lorca continued asserting that all "the theatrical possibilities" (Obras 218) range from the latent sexuality in Cervantes' comic dramas to the abstractness of Calderón's autos. It is through Cervantes how theater arrives, Lorca continued, to the "most schematic farce" that prefigures the contemporary plays of Pirandello (Obras 218). This "schematic" structure was indeed the main principle sustaining both his puppet plays and his human farces of the 1920s, both at the levels of plot construction and character development. Parallel to The Butterfly's Evil Spell and Mariana Pineda, Lorca's dramatic productions throughout the 1920 s were farcical—or 'tragicomic,' to use an alternative term also of his own-highly indebted to the baroque theater of Cervantes. In Federico and his World, a study published posthumously in 1980, Federico's brother Francisco provided very specific keys to understanding Lorca's puppet theater through Cervantes' lens. Francisco García Lorca observes how puppet theater operates by "doubling" or "mirroring" the intrinsically fictional nature of the theatrical spectacle (267). He then refers to Cervantes as "the first to figure out how to utilize all the possibilities of the complex phenomenon" (267). This phenomenon consisted of what Egginton defines as 'screen' in the context of the new epistemology of the stage that characterizes the Baroque. The screen, Egginton notes, operates as a "frame separating realities that are nevertheless susceptible to interpenetration and mise en abime" (How 79), as both realms are perceived as mimetically related by the spectators, who are now "capable of projecting an alternate but viable reality into a given space, and recognizing in it models of its own values and modes of behavior" ("Epistemology" 402, his emphasis). The existence of the screen necessarily implies an ontological distinction between the space of the viewer and the space of the fictional characters. In the case of puppet theater, the baroque bleeding of borders between the viewer's reality and what is perceived as an imaginary, alternative space, gets amplified by the fact that spectators of folkloric spectacles, often familiar with the plot being staged, freely interact with actors and puppets in different ways that range from joining the songs and answering questions from them to arguing about the plot and even interrupting the stage action (Veltruský "Structure" 146). The latter case is what occurs in chapter 26 of Part II of Cervantes' Don Quixote.

About the genealogy of Lorca's puppet theater, his brother Francisco explicitly refers to the episode of Master Pedro's retablo-a word that can be translated not only as "traveling show" but also as simply "show" or "stage"- as the direct source for Lorca's own puppet shows. What occurs in this chapter is well known: Don Quixote's belief in the actuality of what is being staged makes him destroy the puppets in an attempt to save what he perceives as a Christian damsel in real trouble of being captured by the moors. Francisco García Lorca observes that Don Quixote's anomalous reaction is not a simple "extra-artistic 
added element" but rather "an expansion of the complex relationship and existing intersection between author-character-public" (268). What Federico's brother notes about the effects of Master Pedro's puppet show is a logical consequence of the Wirkungsästhetik that characterizes the baroque artwork (Moser 25). When discussing the textual precedents of his brother's puppet theater, Francisco García Lorca argues that the numerous dialogues between actors-in the roles of Director or Authorand the puppets under their control are not but variations of the basic scheme that Cervantes first proposed in the Master Pedro episode (268). It is in view of the importance of Cervantes' retablo that I want now to take a stop and reflect on how this typically baroque artifact of the traveling puppet show challenges the notions of static focal point and authorial authority-in this case, Master Pedro's-by channeling multiple voices through the conflicting modes of mimesis and diegesis. By providing a brief analysis of Master Pedro's show, I also intend to show the extent to which Cervantes creates a pattern of "bleeding of borders," to reproduce here Egginton's terminology, one that will later become a constitutive feature of Lorca's puppet theater. I will approach the Master Pedro episode in relation with another Cervantine retablo, one that was part of a collection of texts that Cervantes never saw staged and that he gave to print in 1615, the same year he published Part II of Don Quixote, and one year before his death. I am referring to his The Marvelous Puppet Show, Cervantes' best known interlude, and, as Mary M. Gaylord observes, one "inextricably linked" (118) to the retablo of Master Pedro that triggers Don Quixote's violent reaction.

Francisco García Lorca notes that retablos such as Master Pedro's were pretty much extinct in early twentieth-century Spain, a historical fact that reinforces the literary and intertextual nature of Lorca's retablillos, a "Cervantine reminiscence" (269). Francisco's words ratify what Federico García Lorca told Adolfo Salazar, a friend from the Residencia de Estudiantes, in a letter from August 1922. Lorca had spent the summer in the village of Asquerosa, Granada, broadening his knowledge of popular culture. In this letter, Lorca detailed his ethnographic efforts to bring back to life the cristobicas puppets: "I ask everyone, and they are giving me all kind of enchanting details. These puppets have already disappeared from here, but the things that the old folks remember are picaresque to the extreme, and they will make you fall over with laughter" (Obras 718). The Cervantine retablo was an exception itself, as it was never truly relevant in the Spanish folkloric tradition. Cervantes knew this theater in his years in Italy, in the 1570s. One reason for Cervantes' inclusion of this foreign art form in Don Quixote is that it served him to materialize what is regarded as a recurrent metaphor in his novel, that of the strings that denote the author's control over his creations. It was through the metaphor of author as puppeteer, Helena Percas de Ponseti observes, that Cervantes produces an "indirect portrayal of Don 
Quijote, Sancho, their chronicler, Cide Hamete Benengeli, of Maese Pedro, the puppeteer, and even of Avellaneda, the author of the apocryphal Don Quijote" (51). Cervantes enlisted this puppet tradition of Italian origins for the purposes of his baroque mise en abyme, and a similar literary gesture is behind Lorca's retablos, since these traveling theater shows were almost nonexistent in early twentieth-century Spain.

At work in Master Pedro's puppet show is a complex chain of discourses that stem, allegedly, from an original and 'true' historia contained in the Legends of the French emperor Charlemagne. Master Pedro operates his puppet show with the help of a trujamán, a young man who narrates the story and who stands out as a double mediator before the audience, for he is the narrator and at the same time the translator from the French-trujamán, a word of Arabic etymology, stands for 'interpreter' in early modern Spain. When Master Pedro's retablo begins, the boy narrates how the Christian knight Don Gaiferos struggles to rescue damsel Melisendra, Charlemagne's daughter, from the moors. Master Pedro moves the figures from below, hidden to the sight of the audience. Don Quixote interrupts the action in several occasions, raising concerns about the decorum of the fictional world very much in the same way that the character of the Director in Lorca's The Billy-Club Puppets and In the Frame of Don Cristóbal interrupts the action to instruct the puppets on the necessity to avoid gross language when on the stage. Despite his claim to the historical truth of the events depicted and narrated, what Master Pedro presents to Don Quixote is rather a patchwork of partial reports whose validity depends, in the end, on the economic profit that Master Pedro will obtain from it. Don Quixote eventually interrupts the puppet show, beheading figures and smashing the stage. Kenneth Gross has recently devoted an entire chapter of his book Puppet: An Essay on Uncanny Life (2011) to this chapter of Cervantes' novel. Gross reflects on the problematic relationship between the two spaces initially differentiated within the innyard. "The belief that fills the puppets with life creates chaos," writes Gross, "expanding the puppet show to contain within it the living members of the audience. It brings up the threat of actual death in the world which has merely asked to be entertained by puppets" (93). The destruction of the artifacts of Master Pedro's show, Gross continues, paradoxically "enlarges its scope, so that it spills over the threshold of the stage into the large innyard, so materially present to us" (93). When the chaos settles and Don Quixote realizes the consequences of his rapture, what follows is a straightforward case of economic reparation: Master Pedro invokes the knight's honor to make him cover the damages caused, and they get to agree to sit down and examine, one by one, the monetary value of each of the broken puppets.

As I indicated earlier, Cervantes provided Lorca with a blueprint to develop a tragicomic theater for both puppets and live actors. Lorca's puppet plays and tragicomic farces constitute variations of an old plot of the 
European comic tradition, that of the unhappy young woman married to an older man. In The Billy-Club Puppets and In the Frame of Don Cristóbal, Lorca openly questions the authority of theater impresarios by presenting a conflict between the human figure of the Director and the puppets, among them the Poet, that attempt to rebel against him. On the other hand, The Shoemaker's Prodigious Wife and The Love of Don Perlimplin and Belisa in the Garden present a farcical treatment of human passions that approximates the dramatic characters to comic puppets, yet with the particularity that their apparently comic nature is counterbalanced by a disturbing presence of eroticism and violence. In these two plays for human actors, open criticism against the contemporary theatrical industry only appears in the prologue of The Shoemaker's Prodigious Wife, to which I will refer later in this chapter. Lorca still actualizes the stage-audience axis, but it is through theatricalism that he achieves this effect.

The Billy-Club Puppets, subtitled "a puppet farce in six scenes and one announcement," has the external appearance of a children's show but already includes explicit elements of social criticism. The ambiguous Mosquito, "a mysterious personage, part ghost, part leprechaun, part insect" (Billy-Club 15) delivers a programmatic speech on occasion of the play's prologue. This character explains that its theater troupe is running "from the theatre of the bourgeoisie, the theatre of the counts and the marquises, a gold and crystal theatre where the men go to fall asleep and the women to fall asleep too. My company and I were prisoners there! You can't imagine how unhappy we were" (Billy-Club 15). This theatrical 'announcement' [advertencia] shares a number of thematic traits with the Prologue in The Butterfly's Evil Spell, particularly when it comes to the presence of symbols from nature and, specifically, the insect world ("stars," "fields," "moon," "fireflies"), but at the same time it inaugurates a new path as it constitutes Lorca's earliest critique against commercialism. The Billy-Club Puppets revolves around the popular figure of Don Cristóbal, a wealthy man who uses his money to marry the young Rosita despite her being in love with the comic puppet Cocoliche. Don Cristóbal is a Punch figure characterized by the billy club [cachiporra] he always holds in his hand. He eventually cannot stand Rosita's affair with Cocoliche and dies of a comic heart attack. The plot of Lorca's puppet play revolves around the classic conflict of old/young present in numerous folkloric sources, and is also part of the comic tradition of the Spanish interludes and the commedia dell'arte. The bully Don Cristóbal, who has married the innocent Rosita thanks to his monetary power, demands immediate sexual satisfaction from her, arguing that he has paid a good price for it. However, he suddenly collapses from a heart attack-probably caused by his massive consumption of alcohol during the wedding-and falls over the footlights. At this point, the puppet farce seems to shift to a more serious tone, until the rest of the puppets discover that what they are facing is not the death of a real person. Cocoliche, one of Rosita's 
comic lovers, eventually realizes that Don Cristóbal has simply burst: "he doesn't have any blood!" . . . "Look! Look at what's coming out of his belly button! Sawdust!" (Billy-Club 53). ${ }^{6}$

As is well known, a central trait of folk theater is the absence of a fourth wall separating stage from audience, an unmarked situation that Lorca takes as the point of departure for a new type of interaction between stage and spectators. In Lorca's second puppet play, In the Frame of Don Cristóbal, the figure of the Poet intends to control the representation by narrating the events and also sharing his opinion on what happens on stage via direct addresses to the audience-the same overlap of diegesis and mimesis that is visible in Master Pedro's retablo-yet the Director constantly intervenes to make sure the spectacle follows the script. This play consists of a single scene labeled "Spoken Prologue," which begins with an introductory speech by an Author, a character to be impersonated by an actor (in the Buenos Aires world premiere of 1934, Lorca himself played this role). The Author's brief speech frames the fictional world that unfolds with the entrance of the Poet, who also addresses the audience, this time in a very authoritative manner ("Men and women, attention! Child, be still!," In the Frame 19). After finishing his introduction, the Poet steps out of the scripted plot in order to convey a more lyrical version of the ugly Don Cristóbal, but the Director quickly intervenes to remind him that he is paid to deliver an exact number of lines. From then on, the Director will control when the characters enter and leave the stage, how they are presented by the Poet and censors words that may offensive to bourgeois decorum. The Poet is now forced to address the public as "respectable audience" and, after this initial clash, the Director continually watches his words, reminding the puppet of his authority. Rather than engaging in a discussion in aesthetic or moral terms, the Director simply invokes his financial authority. The Director is not ashamed to acknowledge the fact that, had he had the Poet's imagination, he would have fired him long time ago (In the Frame 28). In the meantime, the 'main' puppet play has consisted of an accumulation of carnivalesque acts that invert social decorum: Rosita's Mother markets her daughter's beauty in corporal terms ("For her breasts, now they seem, / like two tangerines, / and her little ass round / like cheese by the pound," In the Frame 23); she sells her daughter to Don Cristóbal ("I have a daughter. How much will you give?," In the Frame 24); Rosita enters the stage declaring her unrestricted sexual desire, fantasizing about multiple men ("a young guard," "an archbishop," "a general," "twenty young fellows / from Portugal," In the Frame 26); finally, Rosita commits infidelity with three different characters (among them, the Poet) while Don Cristóbal is drunk and incapacitated in what was supposed to be their first night together. When Don Cristóbal hears that Rosita is giving birth to five babies off stage, he beats Rosita's Mother with his billy club and attempts to do the same to Rosita. The action is 
interrupted by the Director, who grabs the puppets, stops the representation and makes a final speech in defense of theater of popular roots (In the Frame 28-31).

The rudimentary plot consisting of a sensual young woman forced to married an impotent old man, what triggers the action in The Love of Don Perlimplin and Belisa in the Garden, is a case of transposition of patterns from popular puppet spectacles, with the added twist of a very explicit intertextual lineage with Cervantes' interludes. ${ }^{7}$ Both The Shoemaker's Prodigious Wife and The Love of Don Perlimplin and Belisa in the Garden crystallize as the result of the intersection of the languages of puppets and human actors, but ultimately they evolve toward opposite sides of the spectrum. In true Cervantine fashion, the dramatis personae in The Shoemaker's Prodigious Wife are human figures whose tragicomic nature is due to the sketchy characterization typical of puppetlike stylization. Don Perlimplín, on the contrary, initially constitutes the ideal metaphor of the man-puppet, a creature without will that is ordered to marry a young lady because his servant Marcolfa desires so, but as the plot evolves he figures out how to become human by becoming the author of a private passion play that concludes with his immolation over his young unfaithful wife. In the case of The Shoemaker's Prodigious Wife, we witness a cast of human figures resembling puppets in a highly theatricalized play; inversely, Don Perlimplín is a puppet who eventually becomes human in our eyes-not any human, but an archetypal Christlike figure-through his sacrifice.

The prologue of The Shoemaker's Prodigious Wife constitutes a direct appeal to the audience and is a direct precedent for the "Spoken Prologue" that is In the Frame of Don Cristóbal. On the occasion of the premiere of The Shoemaker's Prodigious Wife on December 24, 1930, Lorca wrote a programmatic prologue to be delivered by the figure of the Author, which he himself played on the opening night. In this prologue, the Author insists on his position of superiority over the spectators, reversing the lack of independence that was characteristic of the weak authors portrayed in Lorca's puppets plays. The Author begins addressing the audience as "worthy spectators" but he then rectifies ("No, not 'worthy spectators'; merely 'spectators"”), declaring that

behind that word 'worthy' there seems to be a slight tremor of fear and a sort of plea that the audience should be generous with the mimicking of the actors and the workmanship of the playwright's genius. The poet does not ask benevolence, but attention, since long ago he leapt that barbed fence of fear that authors have of the theatre. (Shoemaker's 59)

Delivering the prologue with the curtain still down, the Author orders the Shoemaker's Wife to be silent ("Shut up!") and to remain offstage 
until the play begins ("I want to come out!," 59, she insists). The Author's inharmonious relationship with both the external (audience) and the internal (dramatis personae) levels of the play will later be reproduced in a different but related space: the hostile environment that threatens the Shoemaker's Wife, a threat that develops into an imminent violent ending. The tension increases when the Husband leaves home after continuous marital disputes, and she begins to receive sexual innuendos from the men who frequent her house, now converted into a tavern for her economic survival. The townspeople around the house fulfill the function of a chorus that reacts against what it is considered to be an inappropriate behavior from the woman. They first do it with ironic ballads - the use of offstage songs here anticipates The House of Bernarda Alba-and, as the action advances, their presence threatens to become a riot. The relationship between stage and auditorium is replicated here through the scheme of theater within theater, as the Shoemaker's Wife becomes the object of the gaze of the anonymous villagers who monitor her through the windows of her house.

One aspect that has traditionally puzzled the critics is the generic indeterminacy of The Shoemaker's Prodigious Wife. At first sight, the comic nature of the play seems certain given its typical carnivalesque plot-the young woman unhappily married to an old man. Nonetheless, Lorca's denomination of the play as "violent farce in two acts" forces the interpreter to reconsider its initially unquestioned comicality. In this "violent farce' the behavior of the Shoemaker's Wife lacks realistic verisimilitude, as it ranges from childish joy to unrestrained violence without further psychological justification. Moreover, the fact that her speeches contain multiple echoes from ballads and popular songs only serves to attenuate the audience's empathic response to this highly theatricalized character. The tension between the Shoemaker's Wife and the neighbors/spectators becomes unbearable as the second and last act of the play unfolds. Her conversation with the Mayor clearly reflects this situation. The Mayor, who previously tried to teach the Shoemaker how to tame the young woman (Mayor: "it seems unbelievable how a man who calls himself a man can't dominate not one, but eighty females," 69), now intends to take advantage of the man's absence and seduce his Wife. When she rejects the proposition of this violent old man, very plausibly the human counterpart of Don Cristóbal, the Mayor threatens to put her in jail, a response that shows the extent to which the woman is condemned to suffer the punishment of the community. Luckily for her, the discussion is interrupted by a trumpet call, "florid and most comical" (Shoemaker's 88) that announces the arrival of an unexpected show: A puppet master has come to town and is said to be heading for the young woman's house. The Shoemaker's itinerant puppet show can be interpreted as the passage to an alternate reality, one that better suits the woman's idealist dreams. Nonetheless, beyond the appearance of an escapist 
entertainment, the puppet show is actually a trick that the old husband deploys in order to rewrite the story of his marriage-he puts the blame on her. He does it before the internal audience of the townspeople and, at the same time, the external audience of Lorca's play. The puppeteer is, in truth, the husband in disguise, and Lorca's stage directions stipulate that everybody will recognize his real identity except his young wife, who will be therefore condemned to a state of ignorance during the whole puppet show. The inauthentic condition of the spectacle is evident when the husband opens the function with the mandatory "worthy spectators," precisely the words that the Author had associated with servility in the play's prologue. When the resentful husband, probably unaware of the credibility of his own artifice, depicts an imagined knife fight between two men who fight for the woman's love, he is somehow approving her punishment. The confusion of fictional levels reaches a point whereby a boy, acting in his capacity as messenger, interrupts the show to announce a tragic incident that has occurred in the outside world. The Boy talks to the Shoemaker's Wife with the naive vocabulary typical of a play that Lorca denominated as a 'violent farce': "Two or three young men have wounded each other with knives, and they're blaming you for it. Wounds that bleed a lot" (Shoemaker's 99). The townspeople surround the house and the Husband reveals his real identity in an attempt to restore order, yet nobody, not even his wife, shows has any respect for him now. It is at this point that the action in The Shoemaker's Prodigious Wife gets interrupted, but one can assume that a violent ending is going to take place, even though the Shoemaker's Wife still defies the crowd with the last words of the play: "come ahead, come ahead if you want to. There are two of us now to defend my house. Two! Two! My husband and I. (To her husband.) Oh, this scoundrel, oh, this villain!" (Shoemaker's 104). The tension dramatically increases as the outside chants become more and more perceptible, as stated in the final stage direction: "The noise of the couplets fills the stage. A bell begins to ring distantly and furiously" (Shoemaker's 104).

The premiere of The Love of Don Perlimplin and Belisa in the Garden was originally scheduled for early 1929 in El Caracol theater club, founded and managed by Cipriano Rivas Cherif. Lorca had conceived it as a chamber version for the club subscribers, but it was censored by the military regime of Primo de Rivera due to the motif of cuckoldry in the scene of Don Perlimplín's wedding night. The three existing copies of the play were confiscated and later deposited in the Registry of Pornography. In 1933, in the different political context of the Second Republic, Lorca finally saw this play staged in the experimental theater club Anfístora as part of a two-play program that also included a new stage version of The Shoemaker's Prodigious Wife. At first sight, the rhymed title (Amor de Don Perlimplín con Belisa en su jardin) and the ridiculous name of the protagonist Perlimplín, prefigure a horizon 
of comic expectations. However, its subtitle, "erotic lace-paper valentine" [aleluya erótica] brings to the fore its erotic undertones. This time, Don Perlimplín is not a human version of Don Cristóbal but a naïve middle-aged man who cannot experience sexual desire. When his old servant Marcolfa arranges the matrimony with the young Belisa, he remains ignorant of any sexual implication of his marriage. This can be inferred from his reaction to Belisa's chants from her balcony, "almost naked" (Love 114), according to Lorca's stage directions in the conclusion of the first scene of the play:

BELISA: Ah love, ah love.

Tight in my warm thighs imprisoned,

There swims like a fish the sun.

MARCOLFA: Beautiful maiden.

PERLIMPLÍN: Like sugar . . . white inside. Will she be capable of strangling me?

MARCOLFA: Woman is weak if frightened in time.

BELISA: Ah love, ah love.

Morning cock, the night is going!

Don't let it vanish, no!

PERLIMPLÍN: What does she mean, Marcolfa? What does she mean?

(MARCOLFA laughs.)

What is happening to me? What is it?

(The piano goes on playing. Past the balcony flies

a band of black paper birds.) (Love 111)

While the band of black paper birds accentuates the non-illusionist nature of this infantile tale of love, it is equally true that the presence of an actress "almost naked" on the stage obliges one to reconsider the apparently naïve nature of The Love of Don Perlimplin and Belisa in the Garden. By creating the figure of Belisa as a symbol of radiant sexuality, Lorca foregrounds the active role of the audience when it comes to legitimizing certain moral behaviors on the stage. In The Love of Don Perlimplin and Belisa in the Garden, Lorca uses a different device than he had used in his previous authorial prologues, for now he addresses the audience indirectly, by means of a dialogue between two fictional commentators of the main dramatic action. This dialogue occurs in the scene of the wedding night or, more accurately, "bedtime" (Love 114), for this is the term Belisa uses in order to convince her husband to come to bed.

After the couple turns off the light, two sprites enter from opposite sides of the stage and cover it with a grey curtain. At first sight, these two supernatural figures (to be played by two children, according to Lorca's notes) seem to endorse the dramatic convention stipulating that sexual scenes be concealed from the public's view. The two sprites 
exchange casual greetings, as if making a routine task, and then sit on the prompter-box to chatter about the newlyweds. The alteration of the poetic decorum is evident in their verbal exchange. On the one hand, the colloquial language of these commentators purges the marital scene of any erotic resonance, situating it on a farcical plane; on the other hand, the presence of surrealist speeches illuminates a more disturbing side of Belisa. The First Sprite, for instance, claims to have known Belisa since her childhood years, and recalls how "her room exhaled such intense perfume that I once fell asleep and awoke between her cat's claws" (Love 116). The sprites eventually reveal that their curtain is not aimed at censoring a scene of marital sex, but to conceal the improper behavior of the young wife, who cheats on Don Perlimplín while he sleeps. And, because this is not publicly accepted, the Second Sprite states that this is the reason "why our efficient and most sociable screen should not be opened yet" (Love 116). When the First Sprite declares that "it is not fair to place before the eyes of the audience the misfortune of a good man" (Love 116), he is referring to Belisa's imminent adultery. The seriousness of their dialogue gives way to carnivalesque inversion when the Sprites open the curtain to show Don Perlimplín lying on the bed "with two enormous gilded horns" (Love 117); there are also five ladders and five hats in the bedroom of the newlyweds, comic symbols that stand for "the five races of the earth," in the words of the servant Marcolfa. Don Perlimplín, in light of Belisa's flagrant infidelity, appears as just another reincarnation of the cuckold in the folkloric tradition of the old husband who cannot satisfy his young wife. Lorca, however, modifies the emphasis on lower appetites that is so typical of carnivalesque worlds and now converts Don Perlimplín into a representative of precisely the opposite view: the comic puppet now dreams of a resurrection of his body in quasi-religious terms.

In view of his inability to arise sexual desire in Melisa, Don Perlimplín makes up a plan to seduce her. He invents a parallel persona that writes her the letters that none of her multiple suitors dare to write. As she confesses to her husband, "these letters from him ... They speak about me . . about my body" (Love 123). Don Perlimplín, apparently accepting his role of cuckold, helps her to set up a night-time encounter with the mysterious man in his own garden-the one to which the play's title refers. But, when she expects to meet the young man, Don Perlimplín arrives, announcing his intention to kill the mysterious lover ("He will love you with the infinite love of the dead, and I will be free of this dark little nightmare of your magnificent body," Love 128). Don Perlimplín runs offstage and Belisa stands alone, disconcerted, until she sees a man wrapped in large red cape that she takes as her platonic lover without realizing that he is none other than her husband in disguise. Her husband, with a dagger stuck in his chest, has committed suicide aware of his condition of "manikin without strength" (Love 129), giving himself in sacrifice 
in order to redeem Belisa. Violent and spiritual at the same time, the main character in The Love of Don Perlimplin and Belisa in the Garden is a figure subject to an unfulfilled desire that drives him to death-this desire can be defined as his particular puppet master. Don Perlimplín, rather than a simple comic puppet perceived by the audience from a perspective of superiority, appears as a collage of dramatic types that, in the end, is not irreconcilable with an empathetic response. Initially the old cuckold married to a young woman, he also represents the proud husband who commits a murder to save his honor, and the young and handsome man (at least, in Belisa's imagination) that sacrifices his life for love.

In his two tragicomic plays to be performed by actors, The Shoemaker's Prodigious Wife and The Love of Don Perlimplin and Belisa in the Garden, Lorca duplicates the relationship between stage and auditorium by subjecting the stage events to the gaze of an additional viewer. This agent can be a collective entity included in the fictional world of the play (the neighbors who spy on the Shoemaker's Wife), or two individuals external to the events depicted (the sprites who comment upon Don Perlimplín's humiliation on his wedding night). In this chapter, I have paid special attention to the disruptive presence of narration in Lorca's theater of the 1920s, as it reveals the irresolvable conflict between literal and metaphoric, visible and absent spaces. A Shoemaker who falls in his own trap after telling the false story of his Wife, and an old husband who sublimates his wife's body by projecting an idealized version of himself, are two examples of this strategy of questioning. The relevance of narration in The Public, the play to which I devote the next chapter, is even greater, as now the Director's subversive staging of Romeo and Juliet is only accessible through the verbal reports of those who have witnessed it.

\section{Notes}

1 As early as 1890, Maurice Bouchor and Anatole France endorsed the hieratic expression of the puppets as the best remedy against the personalities of the actors. Their view was influenced by the contemporary Le Petit Thêatre du Marionnettes, which presented puppets of about thirty inches that were manipulated by a group of artists while another group of performers recited the text. In 1891, Paul Fort staged Pierre Quillard's The Girl with Cut-off Hands, defined by Frantisek Deak as the "first distinctive symbolist mise-enscène" (144). An explicit critique of the actors' physicality can be found in Alfred Valette's review of Maeterlinck's Pelléas and Mélisande, performed in 1893 under the direction of Lugné-Poe. Vallette lamented that acting was not completely subordinated to the symbolist principles of abstraction and stylization, for he still felt that the actors were "too human, too concrete, too material" (qtd. in Deak 167).

2 Hernández notes that in this 1923 puppet spectacle "philology and creation went hand in hand in the search for an artistic primitivism" that Lorca's 
group saw as "the roots of the art in any time period, including the most ardent years of the avant-garde" ("Retablo" 37).

3 In a letter to his parents from June 1923, Lorca mentions a new project with Falla to take place in Granada that summer (Obras 769). In a letter from early August to José Ciria y Escalante, Lorca provides more details about this joint enterprise with Falla, Lanz, with Ernesto Halffter and Adolfo Salazar, "the second installment [representación] of the Títeres de Cachiporra" (Obras 777).

4 In the prologue to his 1615 dramatic collection, Cervantes describes himself as a successful playwright in the early 1580s (he claims to have authored "twenty or thirty plays, which were performed without causing cucumbers, or any other missiles, to be thrown at them," Eight 4), who could not resume his playwriting career in the 1610s. "Along came the great Lope de Vega, one of nature's prodigies, and made off with the theatrical crown. The actors all became his slaves and were subject to his rule" (Interludes 4), he continues. A second, more oblique reference to Lope de Vega appears when Cervantes praises the simplicity of Lope de Rueda's pasos in contrast to the prominent presence of theatrical machinery in the contemporary comedia nueva. In older times, Cervantes writes, there were no "cloud machines descending with angels or human souls. The stage was bare except for an old blanket that was pulled from one side to the other on two pieces of rope so as to form what they call the tiring room" (Eight 3-4).

5 As Cervantes recalls in the prologue, in the early times of Lope de Rueda the stock characters were "a black woman, a pimp, a fool, or sometimes a Biscayan" (Eight 3).

6 A comparison of Lorca's play with Blok's The Fairground Booth shows interesting aspects in common, as both pieces share abrupt changes of mood that underscore the conventionality of the theatrical machinery. In The Fairground Booth, a dance ball scene evolves into a slapstick routine, and one of the dancers uses a wooden sword to kill Pierrot, who then falls dead over the footlights. Very similarly to Don Cristóbal in Lorca's puppet play, cranberry juice begins to spurt from Pierrot's head, but suddenly, he returns to life in the best tradition of puppet theater.

7 In "Staging," Juan Ignacio Badenes has recently developed the parallelisms between the characters of the Shoemaker and Don Perlimplín and the old husbands in two of Cervantes' interludes, The Divorce Court Judge and The Jealous Old Man. 


\section{Facing the Audience}

The idea of an artistic and social transformation through theater haunted Lorca during his stay in New York in 1929-30. In October, he wrote to his family: "It is time to think about the theater of the future. Everything that exists in Spain is dead. Either the theater's source changes or it disappears. There is no other solution" (Obras 1144). At that time, Lorca already had The Public in mind, a play he wrote during his fourmonth stay in Havana and completed in his hometown of Granada in the summer of 1930, right after returning to Spain. The fact that Lorca put two of the five acts of the play to print (Act II, despite its overt homosexual content, and the final Act V) in 1933, contrary to his practice of not publishing his dramas, evidences the importance he assigned to this work. On different occasions between 1933 and 1936, Lorca described The Public as the central piece of his project for a new theatrical stage. He insisted on emphasizing the importance of The Public and his projected 'impossible plays' over his commercially successful dramas Blood Wedding and Yerma (The House of Bernarda Alba was not premiered until 1945, in Buenos Aires). Interviewed in April 1936, two months prior to the outbreak of the Spanish War and his subsequent assassination, he explained that to "obtain the audience's respect, I have premiered other plays" (Obras 631).

After the relatively recent publication of the manuscript of The Public, an editorial event that occurred in the late 1970s, Lorquian scholars have interpreted this play in connection with surrealism and expressionism. A second critical strand has also paid special attention at the play in relation to Lorca's own interest in Spanish baroque theater, in particular to the allegorical genre of autos sacramentales mastered by Calderón in the seventeenth century. In this chapter, I align myself with this second interpretative line to account for the theatricalist nature of Lorca's The Public as well as his intent to blur the boundaries between theater and ritual in order to alter the theatrical praxis of his time. Due to the complicated transmission history of the manuscript of The Public, and also due to its semantic complexity, I open this chapter with a review of different textual aspects of the 1930 manuscript of the play. This is the only one that is known to have survived even though Rafael Martínez Nadal, custodian and first editor of this text, referred to the existence of two 
later iterations. In discussing issues of textual nature such as the possibility of a missing act in the 1930 version and the right positioning of the scene that features the Foolish Shepherd, I favor a 'baroque hypothesis' that privileges fragmentation and intertextuality over organic unity. Following this textual discussion, I proceed to situate Lorca within the context of revival of the genre of the auto sacramental that took place in his hometown of Granada around the mid-1920s. This retrieval of Calderón's autos sacramentales materialized in the staging of The Great Theater of the World in Granada in 1927, a production in which Lorca was partially involved. In the final pages of this chapter, I analyze The Public as an eminently theatricalist play, in line with Calderón and Pirandello, and I explain the tumultuous succession of masks and metamorphoses in The Public as a baroque experimentation with theatrical frames that at the same time clashes with what Egginton defines as the "crypt," an impenetrable space reminiscent of liturgical practices.

The history of the textual transmission of The Public is certainly complicated and it is not surprising that it has fueled all kinds of speculations based on different aspects of Lorca's biography. In July 16 of 1936, Lorca left Madrid for his hometown of Granada in an attempt to escape from what he perceived was an imminent military conflict in Spain following the assassination of right-wing politician José Calvo Sotelo by the bodyguards of socialist party leader Indalecio Prieto three days earlier (after Calvo Sotelo's death, Lorca became obsessed about a civil war, according to the testimony of Martínez Nadal; see Martínez Nadal Introduction 14). Before departing for Granada that day, Lorca entrusted to Martínez Nadal the manuscript of The Public, which he eventually deposited it in a safety box in London, where he fled following the outbreak of the Spanish Civil War. Due to the long-time refusal of the Lorca family to release the manuscript, Martínez Nadal had to wait for four decades until he received permission to publish the text, first in a facsimile edition, in 1976, and two years later in a volume that also included another unknown play by Lorca, one that Marie Laffranque titled Play Without a Title (the one I refer to as The Dream of Life, following Andrew Anderson and Menarini, see editorial discussion in the Introduction of this book). After Martínez Nadal's publication of The Public, the text progressively gained popularity thanks to editions by María Clementa Millán (1987), Derek Harris (1993) and, for the first time, in Lorca's collected works, in the four-volume collection that Miguel García-Posada published in the mid-1990s. Martínez Nadal notes that besides the 1930 version that was in his possession, there existed two later versions of The Public that Lorca used for two public readings that Martínez Nadal claimed to have attended in 1931 and 1936. These two versions, according to his recollection of the events, were in manuscript and typescript form, respectively, and according to Martínez Nadal, Lorca considered the 1936 version as "definitive" (Introduction 29). Among the editors of 
The Public, Clementa Millán and Harris, as well as Antonio Monegal (2000), subscribe to Martínez Nadal's assertion regarding the existence of a missing act in the 1930 manuscript. This missing act would be "Act IV," in which a controversial staging of Romeo and Juliet by two male actors is supposed to take place. This textual hypothesis is based on the fact that the first page of the manuscript in Martínez Nadal's hands announces "a play in six acts and one murder," but contains only five acts. Martínez Nadal remembers the play reading in 1931 as one consisting in three acts, each of them containing two scenes [cuadros], a mental reconstruction that corresponds to the six-act structure announced in the first page of the manuscript in his hands (Introduction 33n1).

As observed elsewhere in this book, scholarly debates on Lorca's drama have traditionally revolved around the ideas of completeness and closure, if only as an ideal to aspire to while patiently waiting for the last-and definitive-editorial revelation that will finally reveal what Lorca really meant to tell us. Because of its fragmented textual nature, and its important role in Lorca's life (and, I would say, in his afterlives), The Public has been seen as a complex puzzle waiting to be finally solved by empirical evidence one day. In 1987, a few months after Lluís Pasqual's world premiere of The Public in Milan, renowned Cuban poet Dulce María Loynaz published a piece in the $A B C$ newspaper with a title that had all the ingredients to keep feeding the Lorca biographical mystique: "I did not destroy the manuscript of The Public." Loynaz, whose family became very close with Lorca in his time in Havana in 1930, speculated that it was his brother Carlos Manuel who, in the midst of a mental crisis, might have burned a possible alternate version of The Public, one that could have constituted a present from Lorca to him. In 1989, Loynaz wrote a second piece in $A B C$, "More about Lorca," in which she claimed to reconstruct the supposed missing act of the play. Loynaz recalled an implausible plot in the form of surrealist/sci-fi drama that shows a world in which immortal humans are secluded in a tower that resembles the Tower of Babel. According to Loynaz, when Spanish journalist Moisés Pérez Coterillo visited her in Cuba, and heard from her about this allegedly lost part of the manuscript, he exclaimed that "this was precisely the act that was missing in the text that was used in the premiere of The Public." Scholars have not given serious credit to Loynaz's account, ${ }^{1}$ but her words are symptomatic of a narrative that presents Lorca's life and works as a secret to be decoded very much in the fashion of Orson Welles' Citizen Kane-in this case, we even have a journalist traveling from Spain to Cuba to decipher the Lorquian 'Rosebud.'

In 1996, Julio Huélamo Kosma came up with a persuasive explanation for the apparent absence of Act IV after a careful scrutiny of Lorca's manuscript. Húelamo Kosma (15-24) argued that the rare length of Act III makes it, in practice, a double act, therefore encompassing what Lorca might have originally thought would be Act IV when he began 
writing the text. This application of genetic theory to the 1930 version of The Public can be read in conjunction with a second document, the publication of two acts (II and V) of The Public in the literary journal Los cuatro vientos in 1933. While there are minimal textual differences between the two acts in the 1930 and 1933 versions, it is significant that the literary journal included the note "From a drama in five acts," a fact that came from Lorca himself. The two scholars who have most recently published critical editions of The Public, Javier Huerta Calvo (2006) and Luis Trigueros-Ramos (2013), have favored the idea of a five-act division. ${ }^{2}$ To these explanations of textual nature, I will add my view that Lorca never wrote the scene of the controversial enactment of Romeo and Juliet that gives way to a riot in the theater. It is well known that in most of Lorca's late plays, most notoriously The House of Bernarda Alba, the actions that occur offstage are more meaningful that the ones seen on stage. Moreover, in the particular case of The Public, this tension is exacerbated by Lorca's depiction of the theatrical stage as the superficial space of the theater 'in the open air' and, as I will discuss later, this is a space often associated with the inauthentic symbol of the theatrical mask. I argue that Lorca could have never written the allegedly homosexual staging of Romeo and Juliet precisely because he had opted for a baroque strategy of writing. Severo Sarduy, who coined the term "neobaroque" in the early 1970s, situates the rhetorical figure of the ellipsis as the center of baroque art. As Sarduy puts it, "to sketch the absence it indicates, the Baroque mechanism demands transfer, a route around what is missing and whose absence constitutes its meaning." This absence, Sarduy continues, produces "a radial reading that connotes, like no other, a presence that in its ellipsis indicates the mark of the absent signifier, that to which the reading, without naming it, makes reference in each of its insinuations" (277).

Besides the discussion about the allegedly missing act, a second textual controversy that followed Martínez Nadal's textual arrangement of the manuscript of The Public concerns the existence of a loose sheet of paper that contains a burlesque poem sang by the Foolish Shepherd [el pastor bobo], a comic figure of the Spanish early modern theater repertoire. Martínez Nadal inserted the sheet between the last two acts of the play (in his nomenclature, acts $\mathrm{V}$ and IV) and gave it the title of "Solo of the Foolish Shepherd" [Solo del pastor bobo]. Clementa Millán, García-Posada and Monegal reproduced this arrangement in their editions of the play. To my knowledge, José Rubia Barcia was the first scholar in proposing a textual arrangement alternative to Martínez Nadal's. In a 1986 essay, Rubia Barcia argued that the unnumbered single sheet should be presented to the readers and spectators as a prologue scene (390-1). This would be similarly to what happens in Yerma, a play that opens with Yerma dreaming of a shepherd and a child, as indicated in the first stage direction of that work (390n20). Rubia Barcia read 
this apparently isolated scene, which Martínez Nadal arbitrarily placed between the last two acts of the play, as one that fulfills the function of a prologue song (and prologues are a consistent pattern in Lorca's plays from the 1920s, as discussed in the previous two chapters). Agreeing with Rubia Barcia, ${ }^{3}$ I interpret the Foolish Shepherd's song as a scene that condensates the main symbols in The Public. This scene revolves about the word "careta" [mask], a central symbol of The Public and even anticipates, in a very tenuous fashion, its plot, for the song makes mention of "the murder of Juliet." The stage direction that opens this pastor bobo scene can be easily read as the initial stage direction of The Public:

Blue Curtain. In the center, a large wardrobe full of white masks with various expressions. . . [The Foolish Shepherd] enters from the right. He is dressed in the skins of a barbarian and has a funnel filled with feathers and tiny wheels on his head. He is playing a barrel organ and dancing to a slow rhythm. (Public 41)

It was after his trip to New York and Havana, in 1929-30, that Lorca consistently looked at the Spanish theater of the sixteenth and seventeenth centuries to develop an alternate formula to the commercially accepted theater of his time. As it is well known, when Lorca had the opportunity to direct La Barraca from 1932 to 1935, he developed a comprehensive project of restoration of classic Spanish theater that included the staging of Juan del Enzina's Eclogue of Plácida and Victoriano (c. 1513), one of the earliest dramas of the Spanish tradition. Lorca also staged plays by Lope de Vega, Tirso de Molina and Cervantes, as well as Calderón's auto sacramental Life Is a Dream. Lorca's rewriting of the dramatic figure of the Foolish Shepherd in The Public, in 1930, is of importance given the fact that it immediately precedes his engagement with the Spanish classic repertoire as director of La Barraca. The final stage direction of the Foolish Shepherd scene notes that "he pushes the wardrobe, which is mounted on wheels, and disappears" (Public 42), an image I interpret as a symbol of what became Lorca's own itinerant theater troupe less than two years after his completion of the manuscript of The Public.

The foolish shepherd became a recognizable character in the period of transition from medieval spectacles to early modern drama in the early sixteenth century. One of his characteristic traits was his adaptability to very different generic traditions, both religious and profane. In his classic monograph The 'Pastor-Bobo' in the Spanish Theatre before the Time of Lope de Vega (1975), John Brotherton historicizes the presence of this figure in four distinct genres. In medieval Nativity plays, the ignorant shepherd eventually achieves redemption through the birth of Christ. In the plays written on occasion of the Corpus Christi, which eventually evolved into the auto sacramental, the pastor bobo ignores the doctrine of Eucharist and believes that the bread remains 


\section{Facing the Audience}

bread. Third, in the early sixteenth-century court dramas, the shepherd pronounces the introito and, in addressing the aristocrat audience, his function closely resembles that of the court fool. Fourth and finally, in multiple comedies around the mid-sixteenth century, the cowardice and selfishness of the rustic fool are meant to highlight, by means of contrast, the positive values of the hero. Brotherton notes that besides his inherent rusticity and foolishness, and the variable attributes of greed, laziness and obscenity, the principal trait of this character is his comic use of the northern dialect of sayagués ('Pastor-Bobo' ix). In The Public, Lorca mirrors this exercise of word creation by making the pastor bobo singing in comic, almost child-like riddles (all rhyming in "-eta," the ending of "careta" and "Julieta") and playing with word variations that resemble the trans-rational poetic language first theorized by Russian futurists Aleksei Kruchenykh and Velimir Khlebnikov in the 1910s. In the medieval Nativity plays and in the Christmas pageants [villancicos], the foolish shepherd performed a role of intermediary between Church and parishioners, as this ignorant and rude character participated in the evangelization of the masses by making questions about Catholic dogmas in ways that all the attendees would understand. The foolish shepherd appears in Enzina's profane plays in the early years of the sixteenth century, and, as Brotherton explains, Bartolomé Torres Naharro (1485530) was the first playwright "to appreciate and exploit fully the potential of the pastor bobo as a deliverer of the prologue" ('Pastor-Bobo' 96). In his courtly dramas, Brotherton continues,

[Torres Naharro] attempts, through the introito, to induce the courtly spectators into the realm of theatrical illusion, to participate in the essentially bipartite theatrical experience ... He also employs the Prologue Speaker to rehearse the spectators in their role by provoking a variety of responses from them and thus ensuring their fullest contribution to the performance. ('Pastor-Bobo' 96-97)

In light of this historical evidence, in the past two decades, several scholars have explicitly rejected Martínez Nadal's view on the pastor bobo. Ana M. Gómez Torres has referred to this character as a prologue figure who enjoys "a privileged position in relation to the play" as he "is familiar with its plot" and has the capacity to share it with the audience, showing "a distant attitude that is comic and sinister at the same time" (Experimentación 40). In 1995, Gómez Torres defined the pastor bobo scene as an "introito" and openly called to rectify what she defined as Martínez Nadal's "wrongful placement" (Experimentación 37-8) of the unnumbered sheet containing the shepherd scene in the manuscript of The Public. Gómez Torres also affirmed that the Fool Shepherd "emphasizes theatricality from the beginning of the play and unites metadramatic reflection with metaphysical concern, announcing, 
as in an operatic overture, all the themes that develop in the play" ("Destrucción" 36). In 2006, Huerta Calvo became the first editor of The Public who altered Martínez Nadal's arrangement by opening the play with the pastor bobo scene. Moreover, Huerta Calvo accentuated its classical sources by titling the scene a "loa," the term used to refer the theatrical prologue in sixteenth and seventeenth-century Spanish drama (see his Introduction 24-30 for a full explanation). Trigueros-Ramos, editor of the latest edition of Lorca's play, published in 2013, agrees with Huerta Calvo's textual decision, with the only particularity that he defines the scene as an "introito" rather than "loa." As early as 2000, in an essay on the nature of Lorca's theatrical prologues, Trigueros-Ramos was already arguing for the reclassification of the pastor bobo scene as an "exordium" ("De la tradición" 359).

Switching the discussion from the manuscript of The Public to its context of inception, I find necessary to emphasize the extent to which Lorca's play is part of a critical and artistic rediscovery of Calderón's allegorical drama that was taking place in Spain in the late 1920s. In 1923, Ángel Valbuena Prat defended a doctoral dissertation on Calderón's autos, published as “Calderón's Autos Sacramentales: Classification and Analysis" in the Revue Hispanique a year later. In 1926-27, he published two annotated volumes of Calderón's allegorical dramas in the popular "La Lectura” collection. In 1927, Antonio Gallego Burín, professor at the University of Granada, adopted Valbuena Prat's first volume to stage Calderón's The Great Theater of the World in the Alhambra (five years later, Lorca used the same edition to stage Calderón's auto Life Is a Dream with La Barraca, see a detailed analysis in Sáenz 49-56). This was the first time an auto was staged in Spain since 1765, when a royal decree prohibited this theatrical genre after decades of systematic attacks from priests and conservative critics, as well as from neoclassicist scholars. Before Valbuena Prat's and Gallego Burín's interest in Calderón, a discussion about his allegorical drama in connection to contemporary theater was something simply unthinkable in early twentiethcentury Spain. Marcelino Menéndez Pelayo, the leading historian of Spanish literature in the late nineteenth century and the early twentieth century, a revered authority in the university system, had perpetuated a very negative vision of Calderón in the preceding decades. In the lecture series he held on occasion of the bicentennial of Calderón's death in 1881, Menéndez Pelayo described characterization as Calderón’s “weak point" (17) due to what he considered a tendency to privilege abstract thought over human inwardness. Aligning himself with Hegel, who had referred to Calderón's drama as "abstrakt subjektiver Art" (qtd. in Regalado 208), Menéndez Pelayo described Segismundo, the hero in Life Is a Dream, as “a symbol, not a man” (33). The Spanish scholar also accused Friedrich Schlegel, more favorable than Hegel to Calderón's theater and an advocate of studying Calderón as a 'romantic' author, of not 


\section{Facing the Audience}

having a proper understanding of his art (33). Menéndez Pelayo's negative views on Calderón were dominant in the Spanish academia until the arrival of Valbuena Prat in the mid-1920s, and even several decades later he was still regarded as a reverential figure in the field of Calderón studies despite the one-sidedness of his arguments (see Wardropper).

An exception to Calderón's absence in the intellectual circles of the early 1920s was Enrique Díez-Canedo's publication of four essays reviewing Max Reinhardt's productions of Calderon's The Phantom Lady (1920) and The Great Theater of the World (1922), in both cases the German versions by Hugo von Hofmannsthal. Of these four essays, published in España in 1922, three were devoted to Reinhardt's production of The Great Theater of the World in Salzburg. Due the lack of valid editions of Calderón's autos available for Spanish readers, Díez-Canedo had to include a long paraphrase of the plot of The Great Theater of the World, as well as a selection of excerpts from Calderón's play, in order to help readers to better understand his argumentation (MuñozAlonso "El modelo" 76-7). What Díez-Canedo denounced in 1922 was not, by any sorts, a problem affecting exclusively the reception of Calderón's autos sacramentales. Between 1918 and 1926, for example, The Mayor of Zalamea was the only one of Calderón's profane plays that was performed in Madrid. ${ }^{4}$ It is against this background that the historical importance of Gallego Burín's production in 1927, followed by Lorca's defense of Calderón's theater as director of La Barraca in the early 1930 s, becomes more evident. ${ }^{5}$

Lorca's poetic trajectory is recurrently studied in relation to his participation in the iconic group of the Generation of ' 27 that paid homage to Luis de Góngora in Seville in December 17, 1927, on the tercentennial of the death of the Spanish baroque poet. However, much less importance has been given to the impact that the 'resurrection'6 of the autos sacramentales in Granada had on his theatrical career. Unlike most of the members of the Residencia circle in Madrid in the 1920s, Lorca had first-hand knowledge of the revival of Calderón's autos that was about to occur in his native Granada. In early 1927, Lorca was instrumental in convincing the literary Athenaeum of Granada to sponsor the event, according to the testimony of Valbuena Prat himself (Gónzalez 317), and in May of the same year, Lorca wrote to Gallego Burín expressing his satisfaction for the imminent production of Calderón's auto sacramental (Obras 994). Because he was in Barcelona, assisting Xirgu in the production of his Mariana Pineda, Lorca was unable to attend the staging of The Great Theater of The World in Granada when it took place in June. Still, he had access to first-hand information from Gallego Burín and his brother Francisco, who played the part of the Author and the World, respectively. (In this allegorical play, the Author stands for God, while the World represents the Theater Director who recruits the actors and assigns them worldly roles and costumes to perform the 
play-within-the-play Do Good, for God is God.) In a letter to Falla from July 1927, Lorca celebrated the coverage the event received in newspapers from Granada as well as from Madrid, indicating that "it has finally been a great success in all of Spain and a success for our friend Lanz, who day after day manages to gain our utmost admiration. This gives me extraordinary joy and shows me the many things that can be done, and that we should do in Granada" (Obras 1007, his emphasis). As in the 1923 puppet show in Lorca's family house, Falla and Lanz worked together for Gallego Burín (Falla with the musical arrangements, Lanz as stage and costume designer.) In structural terms, there are obvious points of contact between Calderón's The Great Theater of the World and Lorca's The Public, since both plays operate on the starting principle of the dramatization of the casting of actors for the performance of a secondary play. The idea of actors being assigned roles to "represent" [representar] in their lives is common to both plays. While Calderón makes emphasis on roles that are socially and politically defined, Lorca is more interested in exploiting the semantic density of the metaphor of the mask, an aspect to be discussed later in this chapter. In Gallego Burín's production of The Great Theater of the World, actors initially appeared on stage in white robes and proceeded to remove them as they were assigned their roles in the play (Gónzalez 322), a protocol of undressing that anticipates Lorca's constant play with changes of costumes and identities in The Public.

In the one-year period from Valbuena Prat's publication of Calderón's autos to Gallego Burín's staging of The Great Theater of The World, references to Calderón multiplied in the Spanish press. Most importantly, Calderón's allegorical drama was now discussed in direct connection to contemporary theatrical languages in Europe. In May of 1926, José Martínez Ruiz, Azorin, defined the recent production of Sutton Vane's Outward Bound in the Teatro Victoria Eugenia of Madrid as the staging of a modern auto sacramental, in light of its plot similarities with Calderón's The Great Theater of the World (in Vane's play, eight disoriented passengers traveling in an ocean liner eventually realize that they are dead and that they are about to be judged by an Examiner). In his review for the $A B C$ newspaper, titled "Two Autos Sacramentales," Azorín explicitly compared both plays to then proceed to explain what he perceived as a "renaissance of the Calderonian formula" in Europe. This was "a theater of ideas" that characterized "the newest drama" represented, among others, by Pirandello (4). Azorín's words had an echo in Blanca de los Ríos, author of the four-installment series "Calderón, Precursor of Wagner and Modern Theater," also published in $A B C$ between June and September of 1927. De los Ríos adopted and expanded Azorin's theorization of a new abstract theater called to replace the text-based 'well-made play.' Finally, in an article published in La Esfera in September of 1927, Enrique Estévez-Ortega celebrated Gallego Burín's Granada production, put it in 
dialogue with the revival of Calderón's autos in the German-speaking world and noted the "striking similarities" (qtd. in Muñoz-Alonso "El modelo" 79) between The Great Theater of The World and Pirandello's Six Characters in Search of an Author. In short, it was around Calderón's autos that a larger discussion about a new theater crystallized in a matter of months in Spain, and in this context Pirandello became the example to emulate. This discussion was not unknown to Valbuena Prat and Gallego Burín. In an essay released simultaneously with the staging of The Great Theater of the World in late June of 1927, Valbuena Prat commented three photographs he himself took of the rehearsal, and referred to the first picture as "the scene with the Author and the characters, that, plastically, above all, look like the apparition of the six from the famous play by Pirandello" (qtd. in Gónzalez 322 n50).

Lorca's early engagement with the tradition of the auto sacramental offered him the opportunity to know about Pirandello's theatricalist drama at a time, the mid-1920s, when the work of the Italian director and playwright was only well known by a reduced number of critics in Spain. At the same time, Calderón was for Lorca something greater than an indirect path to learning about contemporary trends in the theater of interwar Europe. What Lorca found in Calderón's religious theater was a model for the type of interaction between actors and spectators that he was trying to develop as an alternative to the illusionist practices of bourgeois theater. As an archaist playwright and director, Lorca projected a ritualistic foundation of the contemporary stage based on his own knowledge of the Catholic liturgy and Calderón's autos sacramentales. In mid-sixteenth century Spain, the appearance of the first professional theater companies was accompanied by the emergence and consolidation of a new form of vernacular religious play, the auto sacramental, which revolved around the controversial dogma of the transubstantiation. In Jonathan Thacker's words, the auto was a "one-act play performed in the street in many Spanish towns and cities to celebrate the Feast of Corpus Christi," whose primary purposes were "to teach and to re-express dramatically (by moving the emotions and the intellect of the audience through the eye and the ear) the redemptive power of Christ, present in the Eucharist" (162). A consequence of the hybrid nature ${ }^{7}$ of the auto sacramental was its unique resistance to being reduced to a mimetic logic (an author somehow puts an alternate reality before the eyes of the spectators) well into the seventeenth century. As Alexander A. Parker explains, the autos were "primarily liturgical, or semiliturgical, in a way that the Corpus Christi plays of medieval England or of any other country never were (63)." Calderón's autos constituted a total and immersive experience that, in a typically baroque way, blurred the boundaries between viewers and performers. Parker emphasizes the fact that those attending Calderón's autos were "asked to be not merely spectators of the drama but actors in it" (201). In writing The Public, Lorca conceived of this ritualistic theater as the source of his utopic project of 
transforming the act of going to the playhouse into an exercise of collective atonement. In a famous interview of late 1933, right after arriving in Buenos Aires, Lorca defined The Public as an "impossible" play due to its condition of "mirror of the audience." The Public, Lorca explained, should reflect back "everyone's drama [which] can be really painful, and generally it is far from honorable" to the point that "spectators would immediately jump out of their seats, full of indignation, and they would prevent the performance to continue" (Obras 444).

After situating The Public in the context of a renewed interest in the auto sacramental in Spain during the late 1920s, in the pages that follow I focus on the dramatic text that corresponds to the 1930 version of the play. This is the only manuscript that has survived, as noted earlier. Given the troubled history of transmission of the manuscript, a discussion of the Lorquian text must begin by acknowledging Martínez Nadal's instrumental role as first editor and interpreter of the play. In the Introduction, I referred to the momentous publication of The Public and Play Without a Title (the latter, edited by Marie Laffranque) in a single volume released in 1978. Regarding the difficulties Martínez Nadal faced to publish The Public, Paul J. Smith observes that it was

the clearest case of a divergence between the playwright and the family who inherited his copyright: for García Lorca had published in his lifetime the most explicitly homoerotic fragment of the play [Act II] . . . and he had repeatedly insisted that El público and the other 'unplayable' plays constituted his real, true theatre. ("Lorca's" 34)

To circumvent the ban preventing him to publish The Public for years, Martínez Nadal released a long critical study on Lorca's The Public in 1970, quoting extensively from the manuscript in his possession. Martínez Nadal revised and expanded this book in 1974 and, 14 years later, in its final version of 1988. This final version of his monographic study carries the title of 'El Público': Love and Death in the Work of Federico García Lorca. Invoking his unique knowledge of the circumstances surrounding Lorca's writing of the manuscript, Martínez Nadal provides an array of interpretive keys to facilitate the interpretation of the symbols in this complex text. While Martínez Nadal attempts to 'domesticate' the meaning of The Public, the play's fragmentary construction and the constant criss-crossing of references defy his monumental project. The first Lorquian scholar to oppose Martínez Nadal's authoritative study was Fernández Cifuentes, who in 1986 established a distinction between "Lorca's The Public" and "Martínez Nadal's The Public" (García 275-93). Fernández Cifuentes opposed what he saw as Martínez Nadal's tendency to "naturalize" (García 279) the meaning of the work by approaching its symbols mostly through a Jungian lens. He also criticized that any minute aspect of The Public was put in retrospective relation to Lorca's writing production before 1930, a strategy 
Martínez Nadal adopts to emphasize continuity over rupture (García 278-80). Following the example of Fernández Cifuentes, a diverse group of Lorquian scholars have rejected Martínez Nadal's classicist approach to focus instead on the semantic contradictions of the text, in most cases adopting deconstructive and poststructuralist theoretical stances (see in particular contributions by Harretche and Huélamo Kosma). From an explicitly Foucaldian perspective, Carlos Jerez-Farrán has argued for an interpretation of the play's "incoherence," "incompleteness" and "lack of the aesthetic harmony" as "signs of the dialectical tensions the homosexual subject experiences in a system that is bent on preventing the existence and authentic articulation of homosexuality" ("Towards" 728-9). He has criticized "traditional criticism," epitomized by Martínez Nadal, for attenuating "the play's homoerotic content, and thereby its political content" ("Towards" 729).

Assuming, along with this most recent critical wave, that my reading will not exhaust the meaning of The Public, I propose an interpretation that emphasizes the ritualistic core of Lorca's play. I read The Public on a historical axis that traverses medieval liturgical drama and baroque drama to eventually crystallize in a fragmentary aesthetic disposition. The Public is a palimpsest that absorbs constructive patterns typical of medieval and baroque dramaturgies such as temporal circularity, non-realistic transition between scenes (montage), and simultaneous presence of several spaces in the main stage. At the same time, The Public contains intertextual references to Shakespeare's A Midsummer Night's Dream-a decade after Lorca's first experimentation with this text in The Butterfly's Evil Spell-as well as Romeo and Juliet, the latter being a play that the Director performs with violent consequences in a never visible space. Lorca's play follows a circular logic, as it opens and finishes with the exact same words: When the Servant informs the Director of the arrival of an unknown audience, the Director responds "Que pase." These words have been traditionally translated into English as "Show them in," but the Spanish verb "pasar" can also be rendered as "to traverse" or "to get through," an interpretation that emphasizes the act of transgressing boundaries. In the first scene of The Public the Director is sitting in his room, one of the private spaces typically associated with the bourgeois drama that Lorca wants to transforms in the eyes of the audience. Those who wait to be ushered in are not persons, but Four White Horses commonly interpreted as symbols of the Director's repressed thoughts. It goes without saying that the difficulty of having four horses dancing and speaking on the stage qualified The Public as an 'impossible play,' at least under realist criteria. The Horses engage in a verbal dispute with the Director in which eschatological concepts abound (mention is made of "toilet," "sweat" and "rotten apples,"), a duel of carnivalesque inspiration that anticipates the crude imagery of the play. The Director resists the temptations embodied by the horses and finally expels them, letting them know that his theater "will always be in the 
open air." After the Horses are gone, the Servant informs the Director of a new arrival of the public. "Show them in," repeats the Director, as if starting a new theatrical function-this time, he has changed his blond wig for a black one. The Director receives the visit of three men in tailcoats that are simply identified as Man 1, Man 2 and Man 3. They are wearing dark beards, an overtly theatrical accessory, as is the Director's wig. The Men salute him with irony ("Mr. Director of the Open Air Theater?" Public 5), and say they have come to congratulate him on his recent staging of Romeo and Juliet. What follows is a series of accusations against a theater that they see as a false enterprise that does not dare to reveal the inner "truth of the tombs." Man 2 provokes the Director: "How did Romeo urinate, Mr. Director? Isn't it nice seeing Romeo urinate?" (Public 5). Then, in a cryptic manner, he inquires: "What was happening, Mr. Director ... when it wasn't happening? And the tomb? Why, at the end, didn't you go down the steps into the tomb? You could've seen the angel carrying off Romeo's sex while leaving another, his own, the one belonging to him" (Public 5). Man 1 becomes the most ardent defendant of a new form of theater, and announces that he is ready "to shoot myself in order to inaugurate the true theater, the theater beneath the sand" (Public 5). The elusive referentiality of this dialogue makes its translation to semantically stable terms difficult. While one can infer the existence of a production of Romeo and $J u$ liet in the past, the mention of the (uncertain) sexuality of an unidentified angel is rather vague. Further, the Three Men locate the source of this theater-to-be-resurrected in a mysterious tomb that would bring together eros and tanatos, the two forces that, once unchained, should make possible the foundation of the theater beneath the sand.

Because a plot paraphrase can only partially explain this verbal exchange, I propose here an intertextual reading of this first encounter between the Director and the Three Men. The influence of surrealist drama, in particular of Jean Cocteau's drama Orpheus (1926), has been traditionally noted by scholars studying the presence of horses and homosexual undertones of Lorca's play. From the point of view of theatrical praxis, however, the most significant intertextual reference is Pirandello's Six Characters in Search of an Author. As is well known, six characters whose story cannot be written meet a stage director and his troupe while they rehearse an actual play written by Pirandello himself, titled Il gioco delle parti. The characters complain about the fact that they are reduced to fixed meanings that the audience can easily derive from their actions and gestures. They also criticize the actors for merely reproducing stereotyped roles instead of exploring the true selves of the characters who they are supposed to enact. The Manager has modified the recognition scene between the Father and his StepDaughter in Il gioco delle parti, cutting the man's sexual innuendos in the brothel where they meet. When the Step-Daughter demands that the scene remain intact ("But it's the truth!"), the Manager sardonically 
responds: "Great! Just what we want, to make a riot in the theatre! . . . What does that [the truth] matter? Acting is our business here. Truth up to a certain point, but no further" (Six 36-7). In Pirandello's play, the Manager's position represents a conservative stance when it comes to relating the business of theater to the expectations of contemporary audiences. He subscribes to a radical differentiation between the drama that is ready to be consumed by a certain public and the possibility of a moral or social debate. In Lorca's The Public, Man 1 even threatens to shoot himself if that is necessary to unveil the theater beneath the sand, as quoted in the excerpt above. The Three Men finally convince the Director, and ask him to represent the most radical drama possible: "Do you think there could be any newer play than us with our beards ... and you?" (Public 6). No matter how detailed, a Pirandellian reading illuminates only one side of Lorca's drama, for The Public is a palimpsest that operates simultaneously on a synchronic and a diachronic axis. I have already mentioned the importance of Calderón's The Great Theater of The World, a hybrid genre, liturgical and theatrical, that dramatized the staging of a play-within-a-play, whose structural similarity to Pirandello's Six Characters in Search of Author was noted by Valbuena Prat and other Spanish critics between 1926 and 1927, as commented earlier in this chapter. My view is that this dialogue between the Director and the Three Men who demand a true theater also maintains an intertextual relationship with medieval liturgical theater. I am referring in particular to the liturgical drama that can be traced back to the first theatrical manifestations associated with the Easter cycles in the tenth century. This liturgical drama was very close to ritual, for the Easter play originated as a dramatic trope interpolated into the Easter Mass. The Visitatio sepulchri trope emerged as a dialogue between the three Maries and the angel who announces to them the resurrection of Christ after his crucifixion. This trope was also known as the Quem quaeritis, the angel's first words to the three Maries ("Whom do you seek in the Sepulchre?"). The following table proposes a comparison between this Easter trope and the opening scene in Lorca's play:

Visitatio sepulchri

- The three Maries visit an angel.

- The three Maries are given permission to speak ("Whom do you seek in the Sepulchre?").

- The angel has no sex.

- The three Maries are told that a resurrection has occurred. The sepulchre is empty.

- Christ has sacrificed himself to redeem humanity.
The Public

- The three Men visit the Director.

- The three Men are given permission to enter the room ("Let them in").

- The angel as an ambiguous sexual figure.

- The Men demand a resurrected theater. They want the Director to descend to the sepulchre.

- Man 1 offers himself in sacrifice for the theater beneath the sand. 
Without claiming that Lorca conceived The Public as a conscious reenactment of this medieval Eastern liturgy, a textual comparison provides sufficient evidence of how The Public returns to the ritual roots of Western drama. As noted in the second chapter of this study, Lorca staged the oldest liturgical play in the Spanish language, the twelfth-century Mystery Play of the Three Wise Kings, at his family home in Granada in 1923. The liturgical, almost ritualistic tone of Act I of The Public acquires a new semantic dimension when interpreted in connection of the religious imagery in Act IV. In his rendition of Christ's sacrifice, Lorca interprets the tradition of the auto sacramental in light of contemporary dramaturgies (expressionism, surrealism), and stresses the participatory nature of the theatrical event by connecting it to religious ritual. This Act presents what is the most powerful transformation of the play when it comes to foregrounding archetypical associations: The mutation of Man 1/Gonzalo into the Red Nude crowned with blue thorns, his crucifixion ${ }^{8}$ placed in the center of the stage on a vertical bed that faces the audience. Or, instead of a crucifixion, it is more correct to describe it as the staging of a crucifixion, for Lorca subjects this sacred image to a theatrical lens that foregrounds the artificial nature of what is being shown. In the opening stage direction, Lorca conceives the martyrdom of the Red Nude as "though painted by a primitive" (Public 33) in pre-Raphaelite style to be situated at the center of the stage. The façade of a university building stands to the right side of the stage. The visible theatrical space appears, therefore, divided into two parts. There is also a third space that exists in the background, with arches and stairs leading to a contiguous, unseen theater space where the representation of Romeo and Juliet has taken place. ${ }^{9}$ In the opening dialogue of this Act IV, a Male Nurse informs the Red Nude that the spectators in this second theater are demanding the death of the Director while "soldiers and engineers are closing off all the exits" (Public 33). What follows is a surrealist enactment of the passion of Christ that contains multiple Biblical allusions (NUDE: "I wish to die. How many glasses of blood have you taken out of me? . . Father, take away this cup of bitterness from me," Public 33).

As Act IV progresses, the violence that results of the scandalous version of Romeo and Juliet cannot be stopped by any means. The spectators riot and the doors of the playhouse remain locked. When Student 1 asks "Doesn't this theater have an orchestra pit?" Student 2 replies to him that "even the orchestra pits are being packed by the audience" (Public 33). Lorca's technique of montage produces the overlapping of characters and dramatic spaces. A group of five students with "black student gowns and red academic sashes" (Public 33) enters stage right and engages in a discussion about the staging of Shakespeare's play; at the same time, the crucifixion scene of the Red Nude continues at the center of the stage, and a round of applauses is heard from the contiguous (but invisible) third 


\section{Facing the Audience}

space. These three spaces merge when the two actors playing Thieves go down the stairs and Ladies 1, 2, 3 and 4, all in evening dress, enter the 'main' stage coming from the imaginary playhouse, all this with multiple noises coming off that second theater ("a salvo of applause is heard"; "from the theater comes murmurs and the clashing of words"; Public 34-5). Boy 1 also arrives from the contiguous space, reports that "the revolution's reaching the cathedral" (Public 35) and then exits the stage with the group of ladies. What follows is a dialogue between the Students that Lorca uses to convey his thesis for a new theater. The Students discuss what happened when the Director dared to unveil the theater beneath the sand. According to their reports, the audience reacted against the staging of the sepulcher scene of Romeo and Juliet when they realized that it was a young man, and not a woman, who was playing the part of Juliet. Student 4 recalls how "The rioting started when they saw that Romeo and Juliet really loved each other ... the revolution broke out when they found the true Juliet underneath the seats and covered with cotton balls so she wouldn't scream" (Public 35). Student 1 argues that the audience "shouldn't try to penetrate the silk and cardboard that the poet erects in his bedroom. Romeo could be a bird and Juliet could be a stone. Romeo could be a grain of salt and Juliet could be a map" (Public 35). Student 2 poses the final question: "do Romeo and Juliet necessarily have to be a man and a woman for the tomb scene to come off in a heart-rending and lifelike way?" (Public 36). Lorca had affirmatively answered this question as early as 1920, in The Butterfly's Evil Spell, a play that exposes the hazardous nature of love, in imitation of Shakespeare's A Midsummer Night's Dream, by projecting the impossible love of a cockroach and a butterfly (Menarini Introduction 66-9). The imaginary violence in The Public thus becomes the fictional counterpart of the real body of spectators that caused a riot in the premiere of Lorca's first play, as commented in the first chapter of this book.

The discussion among the students that takes place in Act IV of The Public illustrates two conflicting opinions on the relation between actor and dramatic character. If everything becomes transformed on the stage, Student 2 argues, then there is no point in fighting over the materials that are used ("Romeo could be a grain of salt and Juliet could be a map"). Contrary to this view, Student 4 sees the young man's body as a disturbing presence that needs to be controlled. Nonetheless, even though he approves of the censorship of Romeo and Juliet, he still condemns the "detestable" reaction of the audience. Student 1 uses the same adjective but this time with a different idea of theater in mind: "Detestable. A spectator should never be part of the drama. When people go to the aquarium they don't murder the sea snakes or the water rats or the fish covered with leprosy, rather they run their eyes over the glass and learn" (Public 38). Through the constant reversal of meanings, Lorca presents his idea of a didactic theater, one that has 
to be imposed on an audience which should come to the playhouse to learn from the Director, not to impose its 'respectable' morals on him.

Act V, the final one in The Public, functions as a sort of epilogue after the rebellion of the spectators has buried the theater beneath the sand. The Director refuses to accept what the Prestidigitator has to offer: Illusionist tricks that are not the theater beneath the sand that he intends to reveal. To justify the randomness of sexual desire, the Prestidigitator argues, there is no better way than to make use of supernatural elements such as Diana's flower in Shakespeare's A Midsummer Night's Dream. These tricks, however, do not convince the Director of the new theater:

PRESTIDIGITATOR. Without any effort I can turn a bottle of ink into a severed hand full of ancient rings.

DIRECTOR (Irritated.) But that's deception! That's theater! If I spent three days battling the roots and the pounding waves, it was to destroy theater.

PRESTIDIGITATOR. That I knew.

DIRECTOR. And to demonstrate that if Romeo and Juliet are in mortal agony and die in order to come back to life smiling when the curtain falls, then my characters, on the other hand, burn the curtain and truly die in the presence of the spectators. (Public 44-5)

A real drama has occurred on the stage, the Director claims, but this necessary revolt was aborted by an audience that could not accept it. The Director emphasizes the actuality of the events when he tells the Prestidigitator: "Here you are, standing in a theater where authentic dramas have been performed and where a real combat has raged, one that's cost the lives of all the players" (46). This dialogue summarizes the great paradox behind The Public: the representation of a dramatic fiction is undermined by constant references to a painful drama that is actually happening behind the fictional screen. Mark Allinson observes that Lorca's distinction between "theater in the open air" and "theater beneath the sand" is similar to Pirandello's differentiation between "the real" [reale] and "the true" [vero]. "In each case," Allinson explains, "what is attempted is a more authentic form of theatre in which the drama, not dressed up as reality, unfolds naturally on the stage, valued above those conventionalized naturalistic elements in fourth wall-removed drama" (8). In The Public, the access to the utopic theater of the future is indefinitely postponed no matter how many times superficial signs are denounced, or how many layers are taken out during the process.

In the troubled dialogue between the Director and the Men in Act I, the Director first defends himself by invoking respect for the morals of his spectators, but then he reveals what is in reality his deepest fear-the sadomasochist punishment of the "mask." Differing from 
objects such as wigs and beards, the mask is actualized here exclusively by the characters' dialogue, and it is precisely its immaterial condition that makes it a carrier of multiple and (potentially) conflicting meanings. The mask, in The Public, functions as an ambivalent sign. In one sense, the mask constitutes a classic symbol of pretense and artificiality, and in certain passages of the text it is posited that its removal will reveal the Director's emotional authenticity. But, if the act of removing the mask is an act of sincerity, this exposure is not free of pain and contradiction as long as it reveals the fractures of its own self. The mask, finally, also functions as symbol of a collective violence against the individual, as can be inferred from the Director's words. It is necessary to emphasize this dual nature of the Lorquian mask in order to avoid a simplistic interpretation of its role in The Public. In Lorca's agonistic drama, the removal of the mask is not strictly synonymous with the discovery of the inner self, but rather a symbol that causes a tension that cannot be fully resolved. The polyfunctionality of the mask is a perfect example of what Jindřich Honzl defines as the "changeability of the theatrical sign" (86-7), for there is a constant interplay of signifier and signified. The mask can be conveyed through different signifiers (a material object, a verbal construct); at the same time, different meanings are assigned to the same signifier (the mask can be synonymous with liberation, but also with oppression). One of Veltruský's earliest writings, his essay "People and Things in Theatre," from 1940, is also of particular value when it comes to describing the relation between the mask and the characters in Lorca's drama. Instead of a sharp distinction between subject (actor) and object (props), Veltruský conceives of this separation in terms of a continuum that varies depending on their implication on the dramatic action. He writes that "a lifeless thing may be perceived as the active subject and a living human being may be perceived as an element completely without will" ("People" 148). The extreme case of transition from actor to object takes places when the action is reduced to the "zero" level and the actor simply becomes a part of the set-now replaceable by a lifeless figure. Inversely, an object can become a subject when it is the central part of an action and stands on its own afterwards, such as Veltruský's example of a bloody dagger standing on its own after the murderer has fled the stage. In The Public, this tension between subject and object manifests in the mask, a symbol of superficiality but also the active agent that threatens the Director and impedes him from unveiling the theater beneath the sand. Still in Act I, a folding screen is another example of the aforementioned tension between subject and object. This folding screen acquires special importance when it comes to scrutinizing the interior of the Director and of two of the Men who have come to face him. Man 1, who has revealed his real name, Gonzalo, is not afraid to acknowledge a past love affair with the Director. In view of the Director's refusal to admit his homosexual past, Man 1/Gonzalo 
uses the folding screen in order to subject the Director to a physical and emotional transformation. This transformation parallels the inversion of the theater of the open air into the theater beneath the sand:

MAN 1. But I've got to take you to the stage, whether you want to or not. You've made me suffer too much. Quick! The screen! The screen!

(Man 3 brings out a folding screen and places it in the middle of the stage.)

DIRECTOR (Weeping.) The audience is going to see me. My theater will come crashing down ... I've done the best dramas of the season, but now ... ! (Public 6-7)

The Director laments that after very commercially successful productions, among them a 'traditional' rendering of Romeo and Juliet, his interiority will now be visible to the exterior ("the audience is going to see me"). He is forced to pass through the folding screen and what appears on the side is "a boy dressed in white satin with a white ruff. He should be played by an actress. She is carrying a little black guitar" (Public 7). The transformation of the Director reminds the reader of Lorca's famous drawings of Harlequins, melancholic figures usually devoid of visible sexual attributes. Man 1/Gonzalo also forces Man 2 and Man 3 to pass through the folding screen, as he believes they are also hiding their homosexual desires. Man 2 is then transformed into a feminine figure, and Man 3 now appears as a sadomasochist man with a whip and leather wristbands. The folding screen, in sum, reveals the characters' hidden interiority in a way that exposes their repressed or 'true' sexuality, albeit in very essentialist terms that tended to reproduce normative sexual discourses of the 1920s (Jerez-Farrán explains this transformation scene as an instance of "internalized homophobia" on the side of Lorca, see his "El sadomasoquismo" 470-1). As Antonio Monegal has observed, transvestism in The Public consists in an exercise of undressing rather than dressing/accumulating new clothes. The feminine or ambiguous figures that appear from behind the folding screen, therefore, should not be "perceived as a disguise but as an uncovering of the true identity that was hidden under the masculine clothes" (Monegal 207). The continual metamorphoses of the male characters in The Public lead them to a painful exercise of self-discovery that ends up determining the tragic destiny of the two main characters, Director and Man 1. In Act II, the characters of Director and Man 1/Gonzalo mutate into two surrealist figures (Character in Bells and Character in Vine Leaves) that enact a violent dance replete with scatological metaphors. The verbal exchange between them (acting as protagonist-antagonist, as in Greek tragedy) evolves into a physical struggle that combines homosexual drive and death instinct. In Act III, the split between subject and object is complicated as the Director and Men 2 and 3 remove new clothes. The human 
figures go offstage and, in their stead, the clothes stands on their own in what is an extreme instance of an object functioning as a dramatic subject. The harlequin white dress, a ballerina's tutu, and a pair of pajamas with poppies perform actions and deliver speeches independently of the actors' bodies (the actors leave the stage). This occurs in conjunction with the horses that enter the stage in search of the actress who is going to play the sepulcher scene from Romeo and Juliet.

The Public is pierced by numerous surrealist, often eschatological references to a descent to a "sepulcher," and to the "the truth of the tombs." I have referred to this subterranean, 'beneath the sand' space as a source of eros and tanatos, the two forces that somehow put a stop to the potentially endless game of masking and unmasking that is The Public. To conclude this chapter, I propose a novel interpretation of Lorca's play through a new reading that conceptualizes it in light of that unique aspect of baroque theater that Egginton defines as the "crypt." In the late sixteenth-century theater, Egginton notes, the idea of medieval full, transcendental presence

still exists, but now in the form of localized pockets of presence rather than as all-pervading full space. These pockets of presence became the 'real' anchors of the protean stage; they are the place of hard materiality, the breakdown of interpretation, the locale of magic and of miracles. (How 108)

These "localized pockets of presence" constitute what Egginton calls the crypt, a space whose function is to respond to a "desire for substance, for presence, for the real" (How 111) beyond the screen of appearances of the theatrical stage. If the baroque system of mirrors relished in the creation of multiple worlds within worlds, plays within plays, the space of the crypt resisted being absorbed by this logic and remained, well into the seventeenth century, a "solid, full, impenetrable" (How 105) space. What is behind The Public is a typically baroque sense of horror vacui that "may be taken to mean something other than a mere cult of exuberance and decorative excess, a more fundamental feeling of attraction/revulsion concerning the idea of absence" (Castillo 87). If The Public constitutes a chaotic sequence of theatrical tricks, physical transformations and changes of scenery, in the end it is a continuous game that keeps referring us to a potentially infinite act of pulling off disguises without any final 'truth' in sight.

\section{Notes}

1 On the lack of credibility of Loynaz's claim, see Huerta Calvo's statement in Introduction Public 22. Martínez Nadal speculates that the "definitive" (qtd. in Sáenz 12) version of The Public might have ended up in the hands of the parents of Rafael Rodríguez Rapún, who was Lorca's personal secretary, and partner, in the 1930 s. 
2 In his textual reconstruction of The Public, Trigueros-Ramos proposes the "From a drama in five acts" denomination from 1933 as the subtitle of the play.

3 "The initial scene, the front of the wardrobe covered with illuminated masks, each one a different expression on a blue background, is a clear allusion of a humankind characterized by the mask that each individual is given, or acquires, in order to live with their peers. This is, in other words, what centuries ago Calderón demonstrated, although with different purpose, in his The Great Theater of the World" (Rubia Barcia "Ropaje" 391).

4 According to records compiled by Dougherty and Vilches, Calderóns's The Mayor of Zalamea was staged on a total of 17 occasions between 1918 and 1926, with an average of seven nights per production. See their La escena madrileña entre 1918 172-3.

5 In 1928, in a piece for El Sol newspaper, Díez-Canedo wrote that "our true avant-garde theater is Lope and Calderón" (qtd. in Aguilera and Lizarraga Federico 24).

6 See "Resurrección," Antonio Gallego Morell's reconstruction, in 1960, of his father's production of Calderón's The Great Theater of the World in Granada in 1927.

7 Bradley J. Nelson discusses the auto sacramental in contrast to the comedia nueva, the great commercial formula developed by Lope de Vega (who sanctioned its principles in his New Art of Writing Comedies, 1609) and embraced by numerous talented playwrights, among them Calderón himself until 1647. Echoing Egginton's distinction between a medieval, "full" experience of space, and an early modern, theatrical split between subject and object, Nelson establishes a difference between "the homogeneous theatrical space of the comedia nueva" and the "highly contentious and mediated space" of the auto, "one in which the relatively open and homogeneous space of the public plaza and the professional status of the actors function in direct opposition to the conditions of efficacy of medieval rituals of presence" (112). This is why the auto operates, Nelson continues, at "a crossroads between conflicting and in some cases contradictory practices" (113).

8 The first scholar to note the affinity between martyrdom imagery and modernist drama was Walter Benjamin. In The Origin of German Tragic Drama, Benjamin defines martyrdom as one of the elements that differentiates the baroque mourning play from the Greek tragedy, and argues that the Trauerspiel, as a form of martyr-drama, is still alive in the twentieth century. In his words, "if one only learns to recognize its characteristics in many different styles of drama from Calderón to Strindberg it must become clear that this form, a form of the mystery play, still has a future" (Origin 113).

9 Huerta Calvo notes how this triple (and simultaneous) division of the dramatic space imitates the spatial arrangement of medieval paintings ("retablos"). See his Introduction to his edition of El Público, in particular page 47. 

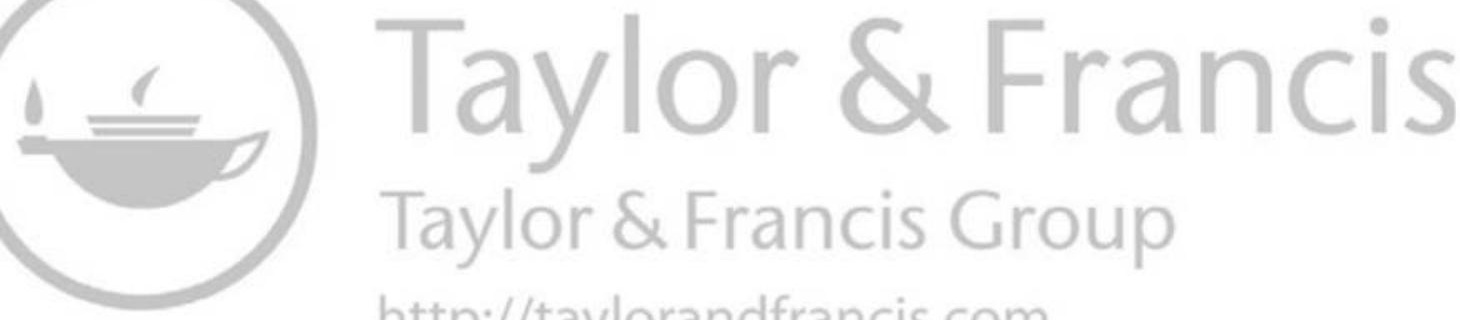
http://taylorandfrancis.com 


\section{Revolution in the Playhouse}

With The Dream of Life (1935), Lorca sought to reconcile the allegorical nature of the auto sacramental and the need to convey a politically radical discourse to impact his audience in the highly politicized atmosphere of the mid-1930s. The shift from The Public to The Dream of Life marks a different type of dialogue with Calderón's The Great Theater of the World, as Lorca moves away from the representation of an interior anxiety of sexual nature (The Public) to produce instead an explicit apology for socialist politics (The Dream of Life). There is also a different engagement with Shakespeare's A Midsummer Night's Dream, a play that had provided Lorca with a theory to justify non-normative expressions of love in The Public (an initial formulation of a defense of the randomness of love was already in his first drama, The Butterfly Evil's Spell). In The Dream of Life, the Author rejects Shakespeare's play for constituting a symbol of the superficial theatricality he intends to abolish. Finally, Pirandello's theatricalism constitutes the third intertextual source of The Dream of Life. This time Lorca does not rely so much on Six Characters in Search of an Author, a text that was a blueprint for the first Act of The Public, but rather on Pirandello's Tonight We Improvise (1930). In The Dream of Life, similarly to Pirandello's Tonight We Improvise, a group of actors are about to represent a play in a bare stage (in Lorca's case, they rehearse A Midsummer Night's Dream) when incidents unfold. Lorca's The Dream of Life expands upon the idea of exposing the vulnerability of stage directors and actors in front of the audience, an idea of central importance in The Public. In The Dream of Life, the blood splatters the stage when a spectator steps onto the stage and shoots a factory worker who had dared to deny the existence of God. This explicit confrontation between authoritarian conservatism and leftist politics constitutes the most extreme instance of politicization in Lorca's theater. In contrast to The Public, Lorca's explicit political position makes the play a much less ambiguous text-and, one could also say, a much more monologic discourse. Lorca's desperate attempt to reconcile his inner anxieties with the cause of the proletariat ends up producing a dialectical exercise of difficult resolution. 
Adopting Elinor Fuchs' terminology in her The Death of Character (36-51), I define The Dream of Life as a modernist mysterium, one that stands in line with the Brechtian idea of 'theater for instruction.' I view Lorca's play as the beginning of a new strand of didactic drama that he could not fully develop due to his early death in 1936. My theoretical gesture to take The Dream of Life out of the group of the so-called Lorca's "mystery plays" (Laffranque) or "metaphysical dramas" (Gómez Torres "El teatro"), formed by The Public and As Five Years Pass, does not take place in a historical void. It is rather a distinction that is historically grounded, for in the last two years of Lorca's life, from 1934 to 1936, his theory of theater experienced a transformation that radically altered his positioning in regards to the relationship between aesthetics and politics. The Dream of Life represents the "theater of the future" that Lorca projected to implement after acquiring the necessary cultural capital, what he described as "the respect of the audience" (Obras 631) in an interview published in April 1936, two months before the outbreak of the Spanish Civil War.

There is enough documentary evidence to challenge the received idea of Lorca as an inherently leftist playwright. In the opening pages of this chapter, my aim is to demonstrate how Lorca consistently avoided the identification of his theater with progressive politics during the first three years of the Second Spanish Republic (1931-34). After reconstructing the historical-artistic context of the early 1930s, I will elaborate on the idea of The Dream of Life as modernist mysterium, and then discuss relevant passages of the play in the closing section of this chapter. My first aim is, as noted above, to contextualize the emergence of a leftist political theater in the late 1920 s and early 1930 s, in parallel to the demise of the reign of Alfonso XIII and the instauration of the Second Republic in 1931. In these years, up until 1934, Lorca continuously presented himself as a non-political playwright. This was in stark contrast with the agenda adopted by other members of the circle of the Residencia de Estudiantes, such as Rafael Alberti, who openly advocated for the transformation of the Spanish theater stage into a revolutionary forum. To trace the evolution of a line of abstract, theatricalist drama that eventually became a didactic tool in the mid-1930s, I will invoke the revival of Calderón's allegorical drama in the late 1920s. As noted in the previous chapter, professors Valbuena Prat and Gallego Burín, and a select group of theater critics, reclaimed Calderón's allegorical drama by defining it as one of the sources for symbolism, expressionism and Pirandellian drama. The trio Lorca-Xirgu-Rivas Cherif was a central link in the importing of Calderón's autos from Gallego Burín's university theater in Granada to the commercial venues in Madrid. In September of 1930, Rivas Cherif accepted the position of artistic director in Xirgu's theater company. This position officially consisted in assisting to the director, 
who technically was still Xirgu, but that in practice became homologous to the role of theater director as it was understood in other European countries. For a period of five years, Rivas Cherif oversaw the selection and staging of seventy plays, mostly in the Teatro Español of Madrid, a public theater whose concession was granted to Xirgu's company from 1930 to $1935 .{ }^{1}$ Rivas Cherif's first production in the Español was a revival of Calderón's The Girl of Gómez Arias, a "generically problematical" (McKendrick 215) tragedy featuring a female character that is abused and sold as a slave, a role Xirgu had already interpreted in 1922 and 1924. In December, two months after The Girl of Gómez Arias, Rivas Cherif staged Calderón's The Great Theater of the World through a new artistic language that integrated the conceptual designs of Edward Gordon Craig, Adolphe Appia and Max Reinhardt. For this first production of Calderón's autos in a Spanish commercial venue in the twentieth century, Rivas Cherif enlisted German scenographer Siegfried Burmann, a disciple of Reinhardt. What Rivas Cherif conceived as an ambitious experimental montage based on platforms and abstract architecture ended up causing a political uproar due to the intrusion of external politics. In the last months of the agonizing rule of King Alfonso XIII, which would eventually come to end in April 14, 1931, with the proclamation of the Second Republic, ${ }^{2}$ the simple mention of the idea of living without a king proved to be sufficient to cause a confrontation between royalists and republicans. In Calderón's The Great Theater of the World, after the fictional actor who plays the role of King is done with his representation and exits the stage, other member of the fictional cast, the actor in the role of Peasant, declares: "As long as it rains on the fields in May, / We're better off-see what I mean?-I With good weather and without a King" (Great 252). This brief speech sparked incidents of violence in the opening night, and from then on it became customary for spectators to utter antimonarchical messages every time the character of the Peasant delivered these verses (Gil 228-9). About this "riotous audience reaction," Carey Kasten observes how this Xirgu-Rivas Cherif production of Calderón's drama "bore witness to a watershed moment in Spanish national politics, seeing the nation advance from antimonarchical unrest to a democratically elected Republic" (17). Lorca, whose first collaboration with Rivas Cherif had been banned in 1929 (The Love of Don Perlimplin and Belisa in the Garden), took a cautious stance toward contemporary politics in a moment when the collapse of the Spanish monarchy was imminent. This was in spite of the fact that the sudden politicization of Calderón's play indirectly benefited him by attracting audiences to The Shoemaker's Prodigious Wife, the first play he saw staged after returning to Spain in the summer of 1930. Xirgu and Rivas Cherif originally programmed Lorca's play as a single performance by the alternative group El Caracol on December 24, 1930, but the play ended up running for 33 nights in early 1931 after 
they incorporated it, paired with Calderón's The Great Theater of the World, into the main space of the Teatro Español (Gil 122-6).

Lorca's reticence to identify himself with progressive politics in the early 1930s stood in contrast with fellow Residencia student Rafael Alberti's plans to conquer the Madrid theatrical stage in a context of rapid social and political transformation. Lorca's artistic rivalry with Alberti initiated when these two Andalusian artists caught the attention of the Residencia circle with works that merged popular southern culture and cutting-edge surrealism in the mid-1920s. As I noted in the Introduction, in early 1927, still before the publication of his Gypsy Ballads in 1928, Lorca was trying gain the favor of the influential leftist poet and critic José Bergamín, asking him to "stop considering me a gypsy, a myth that is more harmful to me than you could know" (Obras 955). Bergamín, however, was not favorable to Lorca's rewriting of folkloric forms and themes. This was a stance shared by other avant-gardist artists such as Dalí, who wrote to Lorca that his poetry lacked "streetcars and airplanes," and defined Gypsy Ballads as "traditional," "old" poetry, one that merely recreates "stereotyped and conformists clichés" (qtd. in Soria 220). In the March 15, 1929 issue of La Gaceta Literaria, Bergamín celebrated the publication of Alberti's latest book of poetry, About the Angels, with a praiseful review that explicitly opposed the "cleanliness" [limpieza] and "neatness" [pulcritud] of Western Andalusia, represented by Alberti's city of Cádiz, to the Eastern part of Andalusia, where the city of Granada is. Alberti's poetry, Bergamín declared, is "pure," "clean," "exact," free of "the turbulence of a Romantic passion." In an overt reference to Lorca's Gypsy Ballads, Bergamín concluded that Alberti's poetry stands at far distance "from everything Jewish or Moorish, and from everything Andalusian and Gypsy, that is, naturally, anti-Andalusian! And, by consequence, at what distance from romanticism or costumbrismo, [that are] dirty, populist, and picturesque!" In the early 1930s, the indirect rivalry between Lorca and Alberti extended to the industry of theater. With Xirgu and Rivas Cherif on his side, Lorca was planning a gradual takeover of the theatrical industry. Alberti, on the contrary, attempted to fashion himself as the enfant terrible of the Spanish scene. In early 1931, Alberti sought to challenge the conventions of commercial theater with a modern allegorical play, The Uninhabited Man. One week before the play's debut, Alberti defined it as "an auto sacramental (without sacrament), free from all theological concern, but not from poetic characteristics" in his brief "Autocritica" in the $A B C$ newspaper. At the end of the play's premiere in the Teatro de la Zarzuela of Madrid, on February 26, 1931, Alberti screamed: "Long live extermination! Death to the rottenness of the Spanish stage." His call that triggered a riot and "split the theater in two parts," according to his own recollection (Arboleda 305). The altercation forced representatives of the theatrical establishment to literally leave the playhouse-it was reported 
that Nobel Prize recipient Jacinto Benavente and the Quintero brothers, who were attending the premiere, quickly abandoned the premises. In his memoir book The Lost Grove, Alberti famously defined the incidents in the first night of The Uninhabited Man as a "resonant battle" in partial emulation of Victor Hugo's Hernani, but the truth is that his play had a very limited impact on the commercial horizon of his time, as it only ran for two weeks. The 'battle' became explicitly political when in its closing night, one of Alberti's friends read an ardent manifesto demanding the liberation of notable members of the Spanish left recently incarcerated by the agonizing regime of Alfonso XIII (Arboleda 305).

Alberti's confrontational theater of the early 1930s came up at a time when the idea of a theater for the masses began to be favored by the Spanish left, to the detriment of the small experiments in select theater clubs in the preceding decade. As Agustín Muñoz-Alonso observes (Introduction 66-70), 1930 was the year of appearance of the Spanish translation of Erwin Piscator's The Political Theater, published in German one year earlier, as well as José Díez Fernández's The New Romanticism, a programmatic collection of essays that proposed a "humanized" avant-garde literature [literatura de avanzada] as alternative to the self-referential art of the 1920s. The proclamation of the Second Republic on April 14, 1931, only accelerated the transition, already in progress, from Ortega's theory of modernist art to the urgent political discourses of the 1930s. Lorca, however, resisted to join this political trend. Coming back to Calderón, the fact that La Gaceta Literaria devoted two full pages to the revival of the autos in its issue of March 15, 1931, evidences how the Madrid literary circles quickly adopted the auto sacramental genre for their own artistic and political purposes. As I observed in the previous chapter, the scholarly revival of Calderón was originally sparked by university professors Valbuena Prat and Gallego Burín, and Lorca himself participated in that process of rediscovery especially in 1926-27. This issue of La Gaceta Literaria featured three pieces. First, a favorable review of Alberti's The Uninhabited Man, signed by Leopoldo-Eulogio Palacios. Second, an essay, by Valbuena Prat, on the history of the metaphor of the theatrum mundi from the stoic philosophers up to the present, with a final reference to Xirgu and Rivas Cherif's recent production of Calderón's The Great Theater of the World. Third, and final, a response from Eduardo Marquina to Alberti's diatribes against the 'rotten' establishment playwrights. By staying silent, Lorca was maintaining sides with Marquina, who had been crucial in convincing Xirgu to stage Mariana Pineda (1927) and, as I will discuss in the next chapter, would be instrumental in the staging of Blood Wedding in 1933.

A sign of Lorca's apolitical stance in the early 1930s was the fact that he did not seek to stage Mariana Pineda when the Second Republic was proclaimed on April 14, 1931, in a context of political fervor that was very favorable to this play. In Granada, people even celebrated the fall 
of the monarchy by gathering around the statue of Mariana Pineda. Multiple critics, among them Lorca's friend Fernández Almagro, invoked the figure of this liberal heroine as symbol of the new democratic regime. The centenary of the execution of Mariana Pineda happened to take place just a few days after the proclamation of the Second Republicshe was executed on May 26, 1831. On the occasion of the centenary celebration, Fernández Almagro wrote in $\mathrm{La}$ Voz that "it is difficult to devise a myth with major operating force. The attractive figure of Mariana Pineda ... has been one of the purest stimuli and most pathetic examples of the modern Spanish consciousness" ("El centenario" 83). $\mathrm{He}$ also made explicit reference to Lorca's play, which he defined as a "dramatic poem of a most singular price" ("El centenario" 86). Similar mentions to Lorca's 1927 drama appeared in other press outlets such as Mundo Gráfico and El Liberal during the week of the centenary, ${ }^{3}$ but Lorca made no movement whatsoever to restage the play. On July 1 of that year, less than three months after the birth of the Second Republic, Xirgu and Rivas Cherif premiered Fermin Galán, a play that Alberti had rushed to write (de Paco "Un nuevo" 155) in homage of an army soldier executed for conspiring against Alfonso XIII a few months earlier. Fermin Galán was a timely historical drama in the form of "a popular ballad," the same compositional pattern adopted by Lorca in Mariana Pineda. Xirgu thought that in the climate of political fervor a bet on Alberti's political play would easily render economic benefits, an intuition that proved right since Fermin Galán had a run of 37 nights that covered the final weeks of the 1930-31 theater season at the Español. In private, however, Xirgu distanced herself from a play that screamed death to politicians and army officers who were "still alive" (qtd. in Balcells 198), as she explained in letter to playwright Joaquín Muntaner.

After the so-called Asturian Revolution of October 1934, Lorca abruptly embraced socialist politics, a move that was followed by a new theory of political theater that crystallized in The Dream of Life a year later. To better contextualize the shift that took place in late 1934, I will first refer to two interviews that Lorca held with the Spanish press in August and September of 1933, while touring northern Spain with La Barraca right before departing for Buenos Aires in early October. In a visit to León, one of the provinces with highest social unrest due to the miners' struggles, Lorca affirmed that the artist

should be exclusively that, artist. The opposite is to prostitute art. There you have the case of Alberti, one of our best young poets who, now, after his trip to Russia, has turned into a communist and no longer makes poetry, although he may believe so, but rather bad literature for newspapers. (Obras 423)

In the second interview, in the city of Santander, ${ }^{4}$ Lorca insisted on defining the work of La Barraca as strictly apolitical. It was, in his own 
words, a project that consisted in "no politics at all. Theater, and nothing but theater" (Obras 426). Lorca maintained this politically neutral discourse while away in Argentina, from late 1933 to early 1934. When approached directly about La Barraca's economic dependence from the Spanish government, he expressed his confidence that his theatrical company would remain unaffected by partisan politics. In an interview with the Argentinian press of January 1934, Lorca described his work as director of La Barraca as his most fulfilling role, more important to him than his playwriting, and rejected the idea that funding for his travelling theater project would be cut by the conservative coalition that had won the general election two months ago (Obras 242-4). This means that, in early 1934, Lorca was still seeing the staging of classic plays in open spaces of small rural towns, before humble audiences who could not afford a seat in a playhouse, as an exercise of popularization of a national culture rather than a political act per se. From a biographical standpoint, there is no doubt about the major impact that the Asturian miners' strike of October 1934 had on Lorca's political consciousness. This uprising developed into the institution of revolutionary soviets in Asturias, and gave way to the use of revolutionary violence against police and members of the Catholic Church in the region. The clash between the leftist militias and the Spanish army constituted the prelude of the war that would finally explode two years later on July 18, 1936. References to this military action and the harsh violence against this failed communist coup permeate Lorca's public speeches in 1935 and 1936. Moreover, this contemporary political event entered his theater, in a very transparent way, through the very explicit verbal exchanges in The Dream of Life, as I will discuss later in this chapter.

Accepting the general thesis that the Asturian revolt constituted an important factor in Lorca's late plunge into the arena of revolutionary politics, my aim is to discuss how this late leftist turn produced a significant alteration in the way Lorca understood theatrical praxis. I have already commented on the defense of a non-political theater he recurrently made until late 1934 . Upon his return to Spain in April 1934, after a five-month trip that took him to Argentina and Uruguay, the Spanish press hailed Lorca as an internationally renowned playwright. The Heraldo de Madrid referred to him as "the return of our ambassador," loved by audiences and praised by critics of South America. Lorca's trip had featured the enormous commercial success of Lola Membrives's production of Blood Wedding (150 nights) and The Shoemaker's Prodigious Wife (70 nights), the latter with new dance and musical arrangements incorporated by Lorca. Lorca also directed his version of Lope de Vega's The Foolish Lady (200 nights), a production for which the architecture of the Teatro de la Comedia of Buenos Aires was altered to imitate the sixteenth-century Corral de la Pacheca of Madrid. ${ }^{5}$ In Buenos Aires, Lorca also gave to stage, very reluctantly, Mariana Pineda, a play that was badly received (20 nights). 
Also, as noted in the second chapter of this book, the Teatro Avenida programmed a puppet spectacle on Lorca's last day in Argentina. The program featured the world premiere of Lorca's In the Frame of Don Cristóbal, Cervantes' interlude The Two Talkers (with Falla's musical arrangements from 1923) and selected scenes of Aeschylus' Eumenides. In addition to his theater, Lorca was very well paid for his conferences and recitals in Montevideo (Gibson 575-6). Lorca's tremendous accomplishments, however, were criticized by sectors of the Spanish left. The most direct criticism came from Pío Fernández Muriedas, who explicitly compared Lorca and Alberti in a piece published in newspaper $\mathrm{La}$ Región. The journalist mocked Lorca as "the great poet of the governmental system," one who "returns from the Americas with his pockets bursting with gold and honor ... the great poet, the best, who knows how to interpret bourgeois idleness and serve it up in well paid books, maintained by the exploiters of the capitalist regime" (qtd. in García Lorca Palabra 315). In the same piece, Fernández Muriedas praised Alberti as the true proletarian artist, one who knows "that bourgeois culture is rotten” (qtd. in García Lorca Palabra 316). In 1933 and 1934, Lorca was also subject of constant criticism from federations of students of the Central University of Madrid that pressured him to transform La Barraca into a propagandistic vehicle of the Spanish left. Emilio Peral, who has recently accessed previously unknown materials on La Barraca, argues that Lorca's decision to add Lope de Vega's Fuenteovejuna to the repertoire of La Barraca was a direct reaction to these attacks (see in particular Peral 15-21).

The Author is an ambiguous fictional figure in The Dream of Life in light of the fact that the Spanish term "autor" stands for not only the author of the dramatic work, in the modern sense, but also the actor-manager who was the "autor" in Spanish Golden Age theater. Lorca's The Dream of Life contains references to both meanings, unlike his puppets plays, for example, two plays that only use "autor" with an archaist meaning. I interpret the violence in the imaginary playhouse of The Dream of Life as Lorca's recreation of his own struggles when learning the trade of theater director when traveling with La Barraca. In the first tour of this itinerant company, in the summer of 1932, the players were attacked by conservative youth activists in the city of Soria. This group boycotted the premiere of Calderón's auto sacramental Life Is a Dream, due to its allegedly sacrilegious orientation, eventually forcing the actors to run away, with much difficulty, from the apse of the Cathedral of the San Juan del Duero where the representation was taking place (Byrd 45-6; Sáenz de la Calzada 128). In addition, students of anarchist and socialist affiliation came to Soria from Madrid to also boycott the performance. They believed that in representing Calderón's allegorical drama, Lorca was using public money to perpetuate the beliefs 
of the Catholic Church. ${ }^{6}$ In the months to follow, Lorca found himself battling obstacles of a different nature, such as hostile crowds in conservative towns not favorable to the liberal ideals of the Second Republic. La Barraca was not allowed to perform in Jaca, while in the town of Estella the company was only given access to a bullring. In Estella, Lorca was harassed by the locals when he was introducing the troupe (Sáenz 142-6). In his travels around Spain, Lorca also experienced episodes that made him reconsider the existence of the dramatic fourth wall. On one occasion, the spectators interrupted the performance of Cervantes' The Careful Guard demanding that the plot be altered to accommodate their desire to see the female character marry the Soldier over the Priest (Sáenz 170). In the town of Vélez-Malaga, one spectator interrupted the performance of Lope de Vega's Fuenteovejuna and called to lynch the actor in the role of the Commender after he sexually abuses peasant Lucrecia (Huerta Barraca 94). ${ }^{7}$ When Fuenteovejuna was staged in the Teatro Coliseum of Madrid in late 1935, in the context of the celebration of the third centenary of Lope de Vega's birth, the conservative press attacked the production for constituting a "profanation" of the national catholic values embodied by the Catholic Kings. Lorca's adaptation was also defined as "a Bolshevik party" and a "petty Russophile drama" (qtd. in Huerta Barraca 98). In his adaptation of Lope de Vega's play, Lorca had cut out the final scene in which the Catholic Kings restore social order by declaring the Commender a failed representative of their royal power. Inspired by Konstantin Marzanov's version of Fuenteovejuna, known to Rafael Alberti and his wife, María Teresa León, in their first trip to the Soviet Union (1932-33), Lorca suppressed entirely the scenes with royal figures. Lorca also added choral songs to actualize the inherently collective nature of a play in the immediate political context of the Spanish Second Republic. ${ }^{8}$ In the professional production of Fuenteovejuna in the Teatro Coliseum, in 1935, Xirgu played the star role of Lucrecia. Discussing one scene of the play, Xirgu expressed her discomfort to Rivas Cherif: "This is not theater, nor art. This is a political rally" (qtd. in Rivas Cherif 132).

I have briefly reviewed Lorca's trajectory as director of La Barraca to make the point about Lorca learning about the difficulty of clearly distinguishing between aesthetics and politics while directing this university theater troupe from 1932 to 1935 . I will now proceed to analyze his writing of The Dream of Life in 1935. He wrote Act I and at least part of Act II of The Dream of Life in the summer of 1935, and there is evidence that he read them to Xirgu and Rivas Cherif in July of that year (Rodrigo 290-2). In September of that year, in Barcelona, Lorca provided a comprehensive account of his project for a didactic theater in an interview with the Catalan communist newspaper L'Hora. After defining the Soviet Union as a "formidable thing" (Obras 597) and noting "the absolute failure of a purely artistic theater" (Obras 598), 
Lorca explained his idea of theater for the masses in terms never used by him before:

If the author adapts himself to the average and predominant mentality, and comes to make his ideas clearly understandable through his work, then, on top of the success that he earns . . he realizes the great task of achieving the true mission of theater, to teach the multitudes. (Obras 598)

In this interview, Lorca praised Piscator's “educative and revolutionary theater" (Obras 599), recognized as a model for his own version of "learning plays," yet he insisted on the fact that the problem with the German director was that he was too inaccessible to large audiences (Obras 599). There is little doubt that Lorca had his idea of political theater fully developed by late 1935, given the perfect correlation between his theoretical statements and his writing practice as evidenced in the extant manuscript of The Dream of Life. The shift to the stage-auditory axis is evident, for rather than a depiction of a quarrel between a director and his characters (as was the case of his puppet plays and The Shoemaker's Prodigious Wife), what now takes place is a direct confrontation between an Author, a character that synthetizes the two sides of Lorca (playwright and director), and the audience. In this regard, The Dream of Life continues the violent narrative already present in The Public. What makes The Dream of Life stands on its own is the way Lorca poses the question of didacticism. When the Author, an alter ego of Lorca himself, first addresses the audience in the opening speech of The Dream of Life, he acknowledges that his words are not a prologue but rather a "sermon." He then poses the following question: "Is a sermon so out of place?" (Dream 94).

In a press interview held in early 1936, Lorca announced a new play, "a social drama, still without a title, featuring the participation of the audience members as well as people entering from the street; the revolution breaks out and they seize the playhouse" (Obras 626). This is the play known today as The Dream of Life. The fact that Lorca referred to this work as "completed" (Obras 626) has created yet another textual discussion among Lorquian scholars, who have proposed different interpretations to account for the only extant manuscript, one consisting of a single act. While the general consensus is that Lorca never got to write the third and last act of the play, ${ }^{9}$ there is some disagreement about the actual existence of a second act, even though there is evidence that Lorca read the Act I, and at least a few scenes of Act II, to Xirgu as early as July of 1935 , as mentioned earlier. In any event, the fragmentary nature of the manuscript is not an isolated case in Lorca's repertoire (see previous discussions on the manuscripts of The Butterfly's Evil Spell and The Public), and The Dream of Life should not be considered different from 
the rest of the Lorquian dramatic corpus because of this circumstance. Moreover, one can argue that the one act of the play that has survived constitutes enough evidence to reconstruct the model of political theater that Lorca was developing in 1935 and 1936. In this respect, Rosanna Vitale has made a call to leave textual controversies behind and consider The Dream of Life as an "unfinished work" [obra inacabada], but one that is not "incomplete" [obra inconclusa]. For Lorca's ideological thesis, she posits, "is clearly expressed in the few pages that are left" (37).

In a letter to Jorge Guillén of March of 1936, fellow member of the Generation of '27 Pedro Salinas lamented the polarization of the Spanish political scene after the victory of the Popular Front in the recent general election of February. In this letter, Salinas describes Lorca's recent public apologies of socialism as the last episode of his years-long literary rivalry with Rafael Alberti. Alberti was the Spanish poet with closest ties to the Soviet Union during the years of the Second Republic (1931-36). In company of his wife, María Teresa León, Alberti completed a three-month trip to the Soviet Union in 1932-33; in their second visit, he declared himself honored to have met Stalin on occasion of the First Congress of Soviet Writers held in 1934 (León chronicled their second visit in a series of eight laudatory articles for the Heraldo de Madrid newspaper). In his letter to Guillén, Salinas writes: "I am so much afraid that Federico, in his noble desire of emulating Rafael [Alberti], will also fall in the 'social' trap. Apparently he has finished a supercommunist drama [un drama comunistísimo] to stand his ground" (qtd. in Soria 222). For the first time in his life, Lorca started seeing himself as a playwright and director invested with the "respect of the audience" thanks to the success of Yerma in Madrid, Barcelona and Valencia in the 1934-35 season, right after his triumphant visit to Argentina and Uruguay. On the plane of organized politics, he was deeply affected by the government's military intervention against the so-called Asturian Revolution in 1934. Moreover, always following the more experienced Xirgu, in the last year of his life Lorca participated in numerous public acts in defense of leftist politics, frequently in collaboration with the Catalan left. On October 6, 1935, on occasion of the first anniversary of the Asturian revolutionary uprising, Lorca offered a recital at the Popular Encyclopedic Ateneum of Barcelona, a progressive cultural institution with more than 20,000 affiliates that held Xirgu as honorary president. The venue was completely filled by a public composed especially of workers, according to chroniclers. Accompanying Lorca, Xirgu herself read out his poetry dressed in the colors of the Republican flag (Rodrigo 280), acting as a walking allegory of the Second Republic before the same Barcelona spectators that had known her in her role of the liberal heroine Mariana Pineda back in 1927. The following day, the same event took place in the University Institute for Social Action of Catalonia (Rodrigo 282). These two public acts on October 6 and 7 had 
a particular connotation in Barcelona, for not only were they occurring on the first anniversary of the Asturian revolt, but also of Lluís Companys' declaration of existence of a "Catalan state within the Spanish Federal Republic" on the same day as the Asturian uprising against the Madrid government. Companys' declaration only lasted a few hoursit was dismantled by the Spanish government on October 7-and had resulted in his imprisonment, with other political leaders, in the summer of 1935. Lorca's involvement in national politics while his Yerma was being represented in Barcelona went beyond these two public acts from early October. On October 23, Lorca's controversial version of Lope de Vega's Fuenteovejuna was staged in the Circo Olympia of Barcelona before a crowd of 8,000 spectators. This was a special performance in honor of Xirgu, who shared the proceedings with Companys and the other politicians in jail (Gibson 627; Rodrigo 289). They were eventually released from prison in February of 1936, after the Popular Front won the third, and last, general election held during the Second Republic years (1931-36).

In his visits to Barcelona and Valencia in late 1935, accompanying Xirgu and Rivas Cherif in their very successful tour of Yerma, Lorca presented himself as a working class intellectual with the immediate project of creating a direct communication with the masses. And, while Xirgu never expressed interest in staging The Dream of Life, Lorca still benefited enormously from being around her, for she had a very intense activist agenda and a political capital accumulated through the years. An analysis of Lorca's words to the press in these last months of 1935 shows the increasing presence of political rhetoric in his discourses. On occasion of the staging of Yerma in Valencia, in November of 1935, Lorca aligned his theater with the quintessentially avant-gardist desire of shocking bourgeois audiences: "one of the finalities that I pursue with my theater is precisely to frighten and terrify a little. I am happy to scandalize. I want to provoke revulsions, to see if people vomit all the badness of contemporary theater" (Obras 611-2). When asked about his "revolutionary theater," he considered it was still "too early" (Obras 615 ) to use that term but that it would be possible once he completed his "aspiration to teach and influence the people" (Obras 615). His great desire was "to be loved by the masses" (Obras 615), and the first immediate step toward that ideal was the first act of The Dream of Life, "a completely subversive act that supposes a true revolutionary technique, a great advance" (Obras 615). In this Valencia interview from November of 1935 Lorca still defined himself as "a true novice ... somebody who is still learning the trade [of playwright]" (Obras 615), but in an interview from April of 1936, two months into the government of the Popular Front in Spain and scarcely three months before the outbreak of the Civil War, Lorca felt confident enough to announce a theater that was revolutionary in theme and form. This play, he explained, was written 
"not for those in the house seats," but for "the balconies and upper seats" (Obras 630). He also defined his discourse as one "purely socialist" (Obras 632). In the last interview of his life, held in June of 1936, Lorca asserted that "no true man still believes in this nonsense of pure art and art for art's own sake" (Obras 635), thus defending a diametrically opposed approach to the one he had maintained until late 1934.

The text that has survived of The Dream of Life contains very explicit formulations of Lorca's late interest in revolutionary politics. The Dream of Life constitutes the crystallization of his idea of urgent, political art, one conceived to break away with the most basic conventions of the commercial theater of his time. In the same interview from April 1936 in which he had announced his desire to write theater not for the "house seats" but for the "balconies and the upper seats," Lorca also proposed to abolish the tailoring of dramatic roles for star-actresses (Obras 630-1). He had been subjected to this practice since the mid1920 s, as discussed in previous chapters of this book. These two statements translate directly into the text of The Dream of Life, for it is in the balcony seats where Lorca situates the proletariat members who fight with the spectators in the expensive seats. In addition, there is no real central female figure that stands out as prominently as in his previous plays, a differential aspect that explains Xirgu's lack of interest in staging the play when Lorca read part of it to her a year earlier.

The risk of problematizing The Dream of Life as one of several works forming a certain creative cycle in Lorca's trajectory is that its very distinctive features-I am thinking in terms of structure and theme-become diffused. The historicity of the dramatic text, one that constituted a direct and transparent response to the Asturian crisis, also results affected when its origins are traced back to years previous to 1934. In order to maintain The Dream of Life as a single-standing work (after all, this play is a self-sufficient model of political theater, and it could have been a blueprint for similar works, such as the project of anti-war play Lorca mentioned in an interview in 1935, see Obras 557) I propose to separate it from the immediate context of the Spanish theatrical industry, and compare it instead to what Fuchs defines as the mysterium, a didactic genre developed by European playwrights in the interwar period. I take issue with Marie Laffranque's definition of The Dream of Life as the third and final work of what she defines as a "mystery cycle" that contains The Public (1930) and Lorca's surrealist play As Five Years Pass (1931). Laffranque's terminological decision was inspired in the words of Lorca himself, who in his visit to Argentina had referred to the latter play as "a mystery of time" (Obras 444). In the introduction to her 1978 edition of the text, Laffranque identifies certain structural and thematic commonalities in the three works and proposes the idea of "mystery" [misterio] as an alternate term to the concept of "irrepresentable" or "impossible" theater that Lorca used on several occasions in his interviews with the 


\section{2}

Revolution in the Playhouse

press between 1933 and 1936 (see Laffranque 299). To explain Lorca's "mysteries" as part of a zeitgeist, Laffranque invokes the rewriting of the genre of the autos sacramentales by a number of representatives of the Spanish left in the 1930s. She specifically mentions Alberti's The Uninhabited Man, from 1931, and one auto written by the young poet Miguel Hernández, He Who Has Seen You and He Who Sees You and the Shadow of What You Were, published in Bergamín's journal Cruz y Raya in $1934 .{ }^{10}$ The temporal frame that Laffranque proposes for the "mystery" genre can be expanded to encompass multiple dramatic attempts at merging expressionism and psychoanalysis with the ritualistic substance of liturgical theater from the mid-1920s until the outbreak of the Civil War in 1936. Ortega y Gasset wrote the prologue for the first volume of Freud's Collected Works in Spanish, published in 1922, and created a space for debate of Freudian ideas in his Revista de Occidente immediately after launching this journal in 1923 (Paulino 71). By the end of the 1920s, the basic principles of Freudian psychoanalysis were known to an extensive number of authors and critics in Madrid, and several members of the circle of the Residencia de Estudiantes had made the exploration of dreaming processes a central pillar of their surrealist aesthetics (Buñuel, Dalí, Lorca himself). In this context of interest on the subconscious, Miguel de Unamuno made an incursion in the genre of subjective drama, a "drama of conscience" [teatro de la conciencia] that crystallized in Dream Shadows and The Other, two plays from 1926. In both cases, Unamuno conceived the theatrical stage as a manifestation of his characters' fragmented minds. He subtitled his play The Other as "a mystery in three acts and an epilogue," the same generic denomination Alberti chose four years later for his play in verse Saint Casilda (1930). Besides Unamuno, Azorin's brief incursion in playwriting, between 1926 and 1930, represented an attempt to escape realism via the incorporation of symbolism and surrealism, in particular his Angelita and The Invisible (see Stimson on Azorin's debt to Maeterlinck's static drama, particularly L'Intruse). In 1929, Cipriano Rivas Cherif staged his own A Dream of Reason in his chamber theater El Caracol (the controversy caused by this play, an open take on lesbianism, was a big reason why its next production, Lorca's The Love of Don Perlimplin and Belisa in the Garden, was banned), and one year later he directed the production of Unamuno's Dream Shadows in Salamanca.

While there is little doubt that Lorca was aware of this contemporary trend of philosophical, oneiric drama, my take is that The Dream of Life cannot be ascribed to the idea of "mystery play" that was relatively popular in the late 1920s and early 1930s in Spain. When proposing the concept of mystery plays Laffranque acknowledges the unique nature of The Dream of Life, a work she sees as a fusion of two "orientations" in Lorca's theatrical production. These two trends are, according to Laffranque, the "abstractness" [generalidad] and "emotional power" [fuerza 
emotiva] of the mystery genre, on the one hand, and the "naked dramatism and the poetic virtue of an immediate, realistic type of dialogue" (303), on the other. She argues that these two trends were to crystalize in a type of social drama "yet to be invented" (303) by Lorca in the last months of his life. Her acknowledgment of the distinctive nature of The Dream of Life ratifies the need to go beyond the generic label of "mystery play" to conceptualize this work separately from The Public and As Five Years Pass. Similarly to Laffranque, Ana María Gómez Torres has proposed the term "metaphysical theater" to encompass The Public, As Five Years Pass and The Dream of Life, yet it is obvious that the central elements that characterize the first two plays ("mental scenarios . . . metamorphoses, splittings, symbolic figures, chiaroscuro techniques," see her "El teatro" 114-5) do not correspond to the transparent progression of the plot of The Dream of Life. The same point can be made about the unique presence of politically doctrinal dialogues in this last play. Following Fuch's terminology in her The Death of Character, I appropriate the term mysterium to denote a modernist theatrical practice with a strong didactic orientation that adapts the expository nature of the original medieval genre to the historical reality of the interwar period. This term encompasses dramatic works that redefine the relationship between stage and audience in the interwar years, particularly from around the mid-1920s. What takes place is a phenomenon broader than the revival of medievalism that had characterized symbolist dramas in the late years of the nineteenth century. This practical (also read: political, didactic) strain of modernist theater adopts structural and symbolic patterns typical of the mystery play and religious drama-from allegorical depiction to images of martyrdom-which are interpreted in reference to political or societal issues. By conceptualizing The Dream of Life as a mysterium it is finally possible to account for the notable distance that exists between the two plays The Public and As Five Years Pass, and the third and last, The Dream of Life. It is a distance that is temporal (a five-year gap between the first two and The Dream of Life) and thematic, as Lorca wrote what we know as The Dream of Life in late 1935 or early 1936 as an explicit defense of socialist politics in response to the military intervention that suffocated the miners' socialist upheaval in the northern region of Asturias in October of 1934.

As a fictional world built on realistic codes, the constant play of metamorphoses that defined The Public is now absent in The Dream of Life. Moreover, the strictly external nature of all the actions in The Dream of Life contrasts with the ontological instability of scenes in both The Public and As Five Years Pass, and linearity takes over collage and layering as the main compositional technique of the play. Finally, I want to observe the crucial aspect that is the fact that, from the point of view of the author as producer of commodities, The Dream of Life came in a moment when Lorca saw himself invested with the necessary 'authority' 
to frontally address the audience after the astounding successes of Blood Wedding in Buenos Aires, in late 1933, and Yerma in Madrid, Barcelona and Valencia in the 1934-35 season. At this point, Lorca had also lived the crucial experience of touring rural towns popularizing Spanish classic theater as director of La Barraca (1932-35). Earlier, I made reference to specific cases of interactions between La Barraca and local audiences that made Lorca obtain the necessary practical knowledge to finally conceptualize his new model of political theater.

Lorca's The Dream of Life evidences the fragile equilibrium between aesthetics and politics in the months immediately preceding the Spanish Civil War. Lorca's final project is to reconfigure the role of the theatrical institution in fostering a new relation between individual and community. Also similarly to The Public, a crucial aspect in The Dream of Life is how, to produce a practical effect on the audience, it turns to diegesis in order to create imaginary spaces in the minds of the spectators, with the final goal of directing their attention to the political reality that is outside the walls of the playhouse. Unlike The Public, however, there is no subjectivist filter causing ontological destabilization. While in The Public the Director was "object of analysis and psychological dissection" and at the same time the agent who "triggers the mental scenes" (Gómez Torres "La destrucción" 36), the fictional constitution of The Dream of Life is the result of an accumulation of reality effects never seen before in Lorca's work-stage, balcony seats and even what is outside the playhouse walls are all supposed to pertain to one and the same world.

Fuchs proposes the term mysterium to distinguish it not only from the medieval mystery but also from the symbolist mystery play, for it goes beyond the limits of the symbolist genre to encompass a wider group of works that extends from Maeterlinck and Mallarmé to Georg Kaiser's From Morn to Midnight and Brecht's The Baden Play for Learning and, finally, Beckett's Waiting for Godot. Fuchs explains how the mysterium "evolved in part as a revival of allegorical methods, however dislocated by a self-conscious, modernist irony, and also continued to bear the stamp of fin-de-siècle symbolist occult aesthetics" (37). Fuchs's mysterium operates, in consequence, as a distinctive model that maintains an ambivalent relation to medieval drama by adopting its allegorical mode while, at the same time, dislocating its ontological stability. The figure of the Stranger, a modernist equivalent of the Everyman in Strindberg's To Damascus, epitomizes this phenomenon. The Stranger is a universalized character descending from allegorical drama, but he is also a figure with a biographical past ${ }^{11}$ as was typical of Strindberg's naturalist phase. The merging of these two characterizing patterns, the generic and the individualizing, is a clear indicator of the hybrid nature of this modernist reading of the mystery play. As Fuchs notes, the mysterium is not simply an esoteric return to medievalism in direct opposition to the 
social concerns of naturalist drama, since "theater writers such as Toller (in Transfiguration), Mayakovsky (in Mystery Bouffe), and even Brecht were also drawn to the mysterium form, as implausible as the project of dressing Marxist doctrine in Christian eschatology might seem at first glance" (Death 44). The uneasy relation between allegory and didacticism is visible in the writings of Brecht and Benjamin since around the mid-1920s, when the existence of the orchestra pit between stage and audience became one of their main concerns. In the late 1920s and early 1930 s, the ideal of a total dissolution of the barrier between stage and audience was progressively substituted by a critical approach to the fourth wall, as dramatists and directors reflected on the ideological implications of this physical separation. In this respect, the theory and practice of Brecht's theater represents the most coherent attempt to reevaluate the distance separating stage from audience. Brecht's dramaturgy matures in a context of increasing politicization of the stage, usually from left-wing activists who, like Piscator, were inspired by the activities of the Russian artists in the early Soviet years. The exposure of the artistic machinery was then considered an act of rebellion against what Brecht referred to as the distribution apparatus, which is also the object of criticism of Lorca's puppet plays and, in very explicit terms, of both The Public and The Dream of Life. The Wagnerian mystic gulf, the great symbol of the separation between stage and audience, was perceived with mistrust by those artists and thinkers who saw in "the filling in of the orchestra pit" ("What" 154), as Benjamin put it in his discussion of Brechtian theater, the most urgent task of contemporary theater. In Lorca's The Public, Student 2 anticipates Benjamin's dictum when he announces that "even the orchestra pits are being packed by the audience" (Public 33). When Benjamin writes about Brecht's attempt to fill in the "abyss" between stage and public, he recurrently uses the term "didactic," a term very close to Mukařovskýs contemporary idea of practical effect in art (see Mukařovský "The Place" 43-7). ${ }^{12}$ Around 1929, Brecht developed the form of theater that he would later call the Lehrstück, which can be translated as "teaching play," "learning play" and, more broadly, "didactic play." The Lehrstück as a theatrical genre invokes a critical response from spectators who are then required to observe, critically, the scenes that are presented before them. Brecht's epic drama intends to transform the spectator into a critical observer with the capacity to think and act. The principal characteristic of the epic theater, Brecht famously wrote, "is perhaps that it appeals less to the feelings than to the spectator's reason. Instead of sharing an experience the spectator must come to grips with things" (23). ${ }^{13}$ In Act IV of The Public, Lorca uses the dialogue between the Students to advance a very similar thesis for a new theater. As noted in the third chapter of this book, the Students are discussing the spectators' violent reaction against the staging of the sepulcher scene of Romeo and Juliet when they realized that it was a 
young man, and not a woman, who was playing the part of Juliet. This discussion illustrates two conflicting opinions on the relation between actor and dramatic character. If everything becomes transformed on the stage, Students 1 and 2 argue, then there is no point in fighting over the materials that are used ("Romeo could be a grain of salt and Juliet could be a map," "It's a question of forms, of masks," Public 35). Contrary to this view, Student 4 sees the young man's body as a disturbing presence that needs to be controlled. Nonetheless, even though he approves of the censorship of Romeo and Juliet, he still condemns the "detestable" reaction of the audience. Student 1 uses the same adjective but this time with a different idea of theater in mind: "Detestable. A spectator should never be part of the drama. When people go to the aquarium they don't murder the sea snakes or the water rats or the fish covered with leprosy, rather they run their eyes over the glass and learn" (Public 38).

Lorca's initial theoretical formulation of an ideal didactic theater in The Public, one that should privilege reason over affect, as expressed through the views of Student 1, will later mutate into the explicit defense of socialist politics that is The Dream of Life. This play constitutes the most illusionistic exercise in Lorca's life as he planned to equate fiction and reality by pretending to take the first one out of the equation. In his opening speech, the Author declares:

Ladies and gentlemen: I am not about to raise the curtain and cheer up the audience with a play on words, or a panorama with a house in which nothing happens and on which the theatre shines its lights for entertainment, and then have you believe that that is what life is all about. (Dream 93)

The most immediate precedent for this fictional authorial/directorial figure was the Author in The Shoemaker's Prodigious Wife (1930), whose presence serves to involve the audience in a comic game of fictional levels (the Shoemaker's Wife interrupts his salutatory speech, and the Author struggles to keep her offstage). In The Shoemaker's Prodigious Wife, this game occurs still with the curtain down, before the beginning of the 'main' play. In The Dream of Life, on the contrary, there is no such autonomous prologue, and it is rather the Author's physical presence that signals the beginning of the performance. The Author formulates his poetics as a teaching exercise consisting in bringing the external "reality" into the playhouse ("Reality is beginning because the author does not want you to feel you are in the theatre ... He wants to teach your hearts a little lesson" Dream 94-5). Taking to the extreme the abolishing of illusion, this Author even speaks in place of a 'real' author, easily identifiable with Federico García Lorca: "The author can write poetry, in my opinion, he's written some rather good poetry, and he's not a bad man of the theatre either. But yesterday he told me that in all art there was a half consisting of artifice which bothered him at the 
moment" (Dream 95). The trope of theater as a space for observing and learning, as opposed to judging based on emotions, becomes evident in the first interaction between the Author and one of the spectators in the orchestra seats:

AUTHOR. Don't interrupt me!

1ST MALE SPECTATOR. I've got a right to. I've paid for my seat!

AUTHOR. Paying for a seat does not mean you have the right to interrupt whoever is speaking, much less to make judgments about the play. 1ST MALE SPECTATOR. Of course it does.

AUTHOR. You can like it or not, clap or remain silent, but never make judgments! (Dream 95).

As Delgado notes, The Dream of Life revolves around two motifs already at work in The Public, the idea of theater as "public forum" and "the issue of [personal] revelation" (164). With a rehearsal of Shakespeare's A Midsummer Night's Dream in the background, the Author refuses to interact with the members of the company (Actress/Titania, Prompter, Nick Bottom, Woodcutter) to instead take down the fourth wall and confront the members of the audience. He finds the most resistance in two couples sitting in the orchestra seats. While 1st Male Spectator refuses to be lectured ("I didn't come here to have lessons in morality or to hear unpleasant things ... I'm going. I thought I was in a theater," Dream 97), her wife, 1st Female Spectator, is attracted by the new "plot" (Dream 97) the Author is promising to them. It is through the dialogue between the Author and this couple sitting in the orchestra seats that Lorca revisits the ideal of transforming the stage into a ceremony carried by non-actors, a utopic notion the Director had advanced in The Public. The Author responds to 1st Male Spectator:

We're not in a theatre. Because they'll come and break down the doors. And then we'll all be saved. There's a terrible falsehood in the theatre, and the characters in plays only say what they can say out loud in front of frail young ladies, but they keep their real anguish silent. That's why I don't want actors, but men and women of flesh. (Dream 97)

In The Public, the revolt of the spectators is only actualized through diegetic means, as the space of the sepulcher is never to be seen. In The Dream of Life, however, the violence is literally taken to the spectator's seats. As happened in The Public, what emerges here is an apology of an artistic form that should go beyond a theater that is synonymous with keeping up "a terrible atmosphere of falsehood" (Dream 97), an untrue environment that is alive with the complicity of the director and his actors. Furthermore, as in The Public, the Director wants not actors who impersonate roles, but rather non-acting people who should present their 
interiority to the spectators. In The Dream of Life, Lorca situates part of the action in the auditorium, dividing the playhouse into levels that correspond to very clear hierarchies. The two 'respectable' couples are sitting in the orchestra seats. Above them, a Young Man in tails stands in the parterre box and engages in discussion with the Director about the limits and possibilities of a revolution of the theater. The intellectual formation of this Young Man makes him a similar figure to the group of students in Scene IV of The Public. Finally, a Factory Worker stands in the front row of the top gallery, obviously one of the cheapest seats in the house. This Worker makes a call to join the socialist revolution ("Comrades!") that is said to be approaching the theater walls.

Besides noises and changes in illumination, diegesis is the main source of information of the confrontation happening outside the theater. The immaterial nature of verbal reports ${ }^{14}$ makes them a very flexible tool to spread the dramatic tension throughout the whole auditorium. In addition, the unifying presence of the dramatic action both on the stage and in the different sections of the theater reinforces the split between what occurs within the walls (theater as pretense) and the violent conflict that is supposed to take place, simultaneously, outside the theater building. Echoing Lorca's praise of popular audiences with La Barraca and the contemporary discourse of socialism, the Director calls to open the doors of the theater to the revolutionary soldiers: "The theatre belongs to everyone! This is the school of the people!," Dream 105). In The Dream of Life, Lorca imagines the utopic idea of tearing down the theater walls as a desperate attempt to dissolve the gap between the safe space of the playhouse and the tumultuous exterior that was the Spanish (and the European) society in late 1935 and early 1936. As Alan Ackerman and Martin Puchner have observed, the notion of the "anti-theatrical" needs to be put in historical perspective: If naturalist reformers opposed what they perceived as the insincere theatrical language of melodrama, a few years later symbolist theater directors reacted precisely against the accumulation of tangible details in the naturalist stage (see Ackerman and Puchner 13). In the case of The Dream of Life, the most immediate enemy is what Lorca interprets as the superficial "theatricality" of bourgeois drama and its panoply of generic, thematic and performative conventions, yet his is, in the end, a far reaching antitheatrical gesture that demands the suppression of the theatrical frame altogether. The full consequences of this scorching gesture have escaped many Lorquian critics, as they have attempted to explain The Dream of Life by assigning it to a certain generic label ("impossible drama," "mystery plays," "metaphysical theater") that somewhat neutralizes its unique stance toward the act of putting a play on a stage before a group of viewers.

The final question to ask is what can be done with a play that seems to call for the abandonment of fiction as we know it. The Dream of Life is an extreme attack against the institution of bourgeois theater and also of the most basic codes of theatrical art (somebody pretends to be somebody 
else in front of a group of viewers). In addition, it is a play that promotes a transparent political message and that, somehow prophetically, calls the spectators to leave their seats and participate in a violent conflict that is taking place outside the walls of the playhouse. It is due to its contradictory nature that, despite the aura around the figure of Lorca, no production of The Dream of Life has obtained a significant success to date in Spain or elsewhere, with the exception of Lluis Pasqual's (1989). As a play dependent on a mimetic dramatic text—and one can claim the text is as illusionistic as it gets-The Dream of Life requires of the very same theatrical frame that Lorca claims to be destroying from within. This destruction even affects the coupling of performing subject and character, as is evident when the Author accuses the Actress, who enters the stage dressed as Queen Titania, of being falsely in love with him ("Where did you learn that line? Which play does it come from?" Dream 102).

\section{Notes}

1 On Rivas Cherif's duties as artistic director of Xirgu's company, and a list of plays staged from 1930 to 1935, see Gil 98-99. In 1932, Xirgu's company merged with the company of actor Enrique Borrás.

2 Following the resignation of Primo de Rivera in January 1930, King Alfonso XIII ordered two army generals to form a government (Dámaso Berenguer, January 1930-February 1931; Juan Bautista Aznar-Cabañas, February.-April 1931) before he eventually fled the country after the victory of republican parties in the municipal elections held on April 14, 1931.

3 See Hernández’s footnote in Fernández Almagro's "El centenario" 86n57.

4 Lorca's presence in Santander in the summer of 1933 constituted his first visit to the International Summer University, created by Fernando de los Ríos, minister of Public Instruction, a year earlier. La Barraca, subsidized by the same ministry, participated in the university's summer sessions from 1933 to 1935. It was through his summer visits to Santander that Lorca acquired prestige as theater director before a selective audience of national and international scholars and journalists (in Santander, in 1935, Italian journalist Silvio d'Amico situated Lorca in the company of Edward Gordon Craig, Konstantin Stanislavsky, Max Reinhardt, Jaques Copeau and Erwin Piscator, see García Lorca Obras 569).

5 For a detailed reconstruction of this production, see Aguilera and Lizarraga Federico 45-57.

6 The following is Francisco García Lorca's recollection of the attack against La Barraca:

On July 15, 1932, La Barraca was ready to revive before the people the glories of our old theater, when a combination — only explicable in terms of political fervor-of conservative students ... and workers of the powerful National Confederation of Workers ... violently attacked the representation of the auto, so that the performance had to be suspended. This was how the play that was intended for the people, a work that was to praise the Eucharist, was stoned by ultra-Catholics and an exalted group of workers. (442-3)

7 Rodríguez-Solás (109-12) provides a recent review of the incidents affecting the itinerant work of La Barraca.

8 As Guillermo de Torre put it three decades later, the popularity of Lorca's version of Fuenteovejuna in Spain, and later in Russia and Germany, "was 


\section{Revolution in the Playhouse}

in great part due to the extraliterary meaning inferred from the presence of a collective protagonist" (166). De Torre was the leading thinker of the ultraísmo movement in the early $1920 \mathrm{~s}$, and author the monumental volume Literaturas europeas de vanguardia (1925; revised as Historia de las literaturas de vanguardia, 1967). After Lorca's assassination, de Torre published Lorca's first Collected Works in Losada, a publishing house he himself founded in Buenos Aires after escaping from the Civil War in Spain.

9 In an interview from April 7, 1936, Lorca refers to his political play as not finished yet, contrary to what he had stated in January. This testimony seems to confirm the idea that he did not write the three acts that he had initially planned for The Dream of Life.

10 This was not, in any event, a homogeneous trend. Alberti denominated his play "an auto without the sacrament [of the Eucharist]," and adapted the theatricalist structure of the auto to contemporary concerns of nihilist orientation. Very differently, Hernández's drama is basically an emulation of Calderonian autos that reproduces, without questioning, the corresponding dogmas of the Catholic doctrine.

11 The need to unveil the painful past of the Director is, interestingly enough, the starting point of Lorca's The Public. In this play, as Strindberg in his trilogy To Damascus, Lorca integrates a dream atmosphere with allegorical patterns of cyclical time.

12 On Benjamin's evolution from the Trauerspiel to his late writings on Brecht's theater, Michael J. Sidnell affirms: "Formerly, Benjamin had posited an artistic embodiment poised between Nietzschean aestheticism and discursive moralizing; now he was so extremely anti-Nietzschean as to endorse a Socratic relation of hero and audience" (26).

13 Brecht also states, however, that "it would be quite wrong to try and deny emotion to this kind of theater. It would be much the same thing as trying to deny emotion to modern science" ("Epic" 23). This last statement, dating back from Brecht's “The Epic Theater and its Difficulties” (1927), is important in order to reconsider critical stereotypes about Brecht's position on emotion in theater. In this respect, R. Darren Gobert has recently explained how Brecht's rejection of emotion (his famous scheme of oppositions) is a gesture of denial of the behaviorist approaches to the audience in both American comedies and Soviet films of the 1920s (Gobert 14). In this multi-cited table from 1930, Brecht confronts dramatic and epic theaters and assigns them the goals of "feeling" [Gefühl] and "reason" [Ratio]. This outright rejection of emotion, however, progressively evolved toward a hybrid approach to audience response until its final codification in his "Short Organum for the Theater," in 1953.

14 On the concept of imaginary space and the way it activates the spectators' participation, see Brušák, in particular 155. 


\section{Writing for the Stage}

The final chapter of this book examines Lorca's internationally renowned plays Blood Wedding, Yerma and The House of Bernarda Alba. Lorca wrote the first two plays, between 1932 and 1934, with the immediate goal of obtaining commercial and critical recognition before proceeding to implement his desired comprehensive reform of the theater industry in Spain (consider his transparent statement from December 15, 1934, two weeks before the premiere of Yerma, about his "perfectly clear trajectory in the theater," Obras 545). While the writing of Blood Wedding and Yerma formed a single and continued effort, The House of Bernarda Alba came out as an independent play in June of 1936, just a few weeks before the outbreak of the Spanish Civil War and Lorca's subsequent execution by a fascist squad in Granada in August of that year. Margarita Xirgu premiered The House of Bernarda Alba in Buenos Aires in 1945. In the analysis of the original context of production and reception of Lorca's plays, I will limit my study to Blood Wedding and Yerma for the obvious reason that he did not stage The House of Bernarda Alba. Nor did Lorca provide any specific clue about a potential production while he was still alive. From the perspective of textual analysis, I propose a unitary approach to these three works, as they recreate identifiable plot patterns from the contemporary genre of the drama rural as well as from Calderón's baroque honor plays.

As Andrew Anderson notes, acknowledging the "strategic" value of Blood Wedding and Yerma should not imply that Lorca used them "merely as tools, compromising his artistic integrity or indeed succumbing to commercial considerations and pandering to public taste" ("Strategy" 217). Lorca composed and staged these two plays while he also attempted to make his whole dramatic production more visible through any means possible. In 1933, he saw staged The Love of Don Perlimplin and Belisa in the Garden, a work banned four years earlier when it was being rehearsed by Rivas Cherif's theater club El Caracol. In the more favorable political context of the Second Republic, the play was finally produced by the Club Teatral de Cultura, a theater club recently founded by feminist activist Pura Maortua Ucelay. It was a one-night event, on April 5, at the Teatro Español, attended by a select audience 


\section{Writing for the Stage}

of critics and artists only. Additionally in 1933, Lorca sent to print Acts II and V of The Public, published in the literary magazine Los Cuatro Vientos. This publication resulted in an exceptional event in view of Lorca's general aversion to publishing his dramatic works. The explicit homosexual undertones of the play, particularly in Act II, were not an obstacle for its publication. During this year of very high theatrical activity, the first two productions of Blood Wedding, in Madrid and Buenos Aires, took place. After the success of Blood Wedding, Lorca proceeded to write and stage a second tragedy, Yerma, a play he eventually completed in the summer of 1934. While directing rehearsals of La Barraca in Madrid before going out on a tour in northern Spain, Lorca expressed his satisfaction with the writing process of Yerma in an interview of July of 1934. Early in the year, actress-manager Lola Membrives was pressuring him to deliver the complete manuscript of the play to her-this personal episode will be discussed in more detail later. Yet, he found a way to resist her impositions. "I believe I have accomplished what I had intended to do" (Obras 536), Lorca claimed in this interview from mid-1934. In this same interview, Lorca famously announced his will to "return to tragedy. Our theatrical tradition obligates us to do so" (Obras 536). Anderson interprets this declaration as an ambitious attempt from Lorca to "immerse the contemporary Spanish stage in its origins and 'true' tradition in order to save it from crass commercialism and to bring it back on to an 'artistic' course" ("Strategy" 217). This exercise of returning to the root of the Spanish theatrical tradition in order to produce an impact on contemporary stage practices conforms to my definition of Lorca as an artist who was both an archaist and an innovator. These two interrelated terms, proposed by Yury Tynianov in his 1929 study of the dynamics of the "old" and the "new" in Russian literature, as I noted in the Introduction, fit perfectly in Lorca's constant negotiation between the tradition of the Spanish theater and the commercial practices of the contemporary theater industry. In the late 1920s and early 1930s, the artists and critics around the Residencia de Estudiantes and journals such as La Gaceta Literaria advocated openly for a "new" and "young" art that should sweep any trace of the "old." Lorca, however, tended to avoid this rhetoric of irreconcilable extremes for most of his career. His most radical public statements came only in 1935 and 1936, in the last two years of the Spanish Republic, as I discussed in the previous chapter.

Right after obtaining the public concession of the Teatro Español of Madrid in 1930, Margarita Xirgu appointed Cipriano Rivas Cherif as her assistant director and literary advisor. One of their first decisions was to program Lorca's The Shoemaker's Prodigious Wife, paired with Calderón's The Great Theater of the World. This was very favorable to Lorca who, upon a recent return from the United States and Cuba, saw The Shoemaker's Prodigious Wife performed in the main space of the very respectable Teatro Español. Lorca's play ran for 33 nights in late 
1930 and early 1931 (Gil 122-6). In late 1932, however, Lorca could not secure the support of Xirgu and Rivas Cherif to produce Blood Wedding. For this reason, he sought the help of Eduardo Marquina in his position of literary advisor in Josefina Díaz's company during the 193233 theatrical season. Lorca's reliance on Marquina for the production of Blood Wedding in 1933 proves the weakness of Lorca's position as producer of theatrical commodities even after seeing Mariana Pineda and The Shoemaker's Prodigious Wife staged in prestigious spaces in the preceding years. The situation was very different when Yerma premiered in the Teatro Español on December 29, 1934, as this time Lorca was a celebrated playwright who counted with Xirgu and Rivas Cherif on his side. Xirgu and Rivas Cherif, in the fourth year of their joint enterprise in the Teatro Español, were at the peak of their career. Xirgu, recognized as the most distinguished actress in Spain, had recently received medals of honors of the Second Republic ${ }^{1}$ and of the cities of Mérida, Barcelona and Badalona. At the same time, Rivas Cherif had finally fulfilled his dream of opening the first modern theater school in Spain, the Teatro Escuela de Arte (1933-36).

In light of its thematic commonalities with Blood Wedding and Yerma, critics have traditionally considered The House of Bernarda Alba (1936, premiered posthumously in Buenos Aires in 1945) as the third and final piece of the project that Lorca defined, in 1933, as his "trilogy of the Spanish land" (Obras 418). I agree with the idea of these plays constituting a trilogy, in broad terms. However, the particular history of The House of Bernarda Alba presents a different concept. First, Lorca never mentioned The House of Bernarda Alba in his many public speeches and press interviews from 1932 to 1936 . Second, in the cases where he referenced a third title, The House of Bernarda Alba was not the play he had in mind. In two press interviews released before the premiere of Yerma, Lorca described Yerma as the second title of a trilogy that should end with The Drama of Lot's Daughters (Obras 545, 548). After the opening night, Lorca announced that the trilogy would end with a play he was now referring to as The Destruction of Sodom. This latter work was, in his own words, "practically finished" (Obras 552). In regard to The Destruction of Sodom, there is evidence that Lorca read its first act to Rafael Rodríguez Rapún and Luis Sáenz de la Calzada in the summer of 1935 (Sáenz 176-7), yet no manuscript survived. The biblically themed play contained an explicit foregrounding of male homosexuality, a direction distinct to Blood Wedding and Yerma. In mid-1935, Lorca also worked on The Dream of Life, projected as the climax of his political theater, as I discussed in the previous chapter. Additionally, he drafted ideas for plays on very different topics, from antiwar works to plays portraying violent and sexual scenes inspired by the Old Testament to a new model of musical theater that would incorporate flamenco music (Hernández Introduction La casa 14-40). While working on the 


\section{4}

various projects during the summer of 1935, Lorca abandoned the idea of a unitary trilogy of the Spanish land.

Lorca's agrarian plays were not the result of an isolated genius who obtained his inspiration from contemporary problems of women in Southern Spain. Instead, these plays came to life in explicit dialogue with the conventions of one of the prevalent genres in the contemporary playhouses of Madrid. The genre of rural drama constituted both the starting point for Lorca, who willingly staged his theater in commercial venues, and the background against which the originality of Blood Wedding and Yerma was to be measured. Had Lorca had the opportunity to stage it in 1936, The House of Berndarda Alba would have also been evaluated as a rural drama. As noted earlier, these three plays relied, in different degrees, on previous formulas of rural dramas (Marquina's versified theater in the first two cases, Benavente's drama in prose in The House of Bernarda Alba) while also constituting modern revisions of the baroque honor plays. It is my view that an analysis of these three plays without consideration of their generic and intertextual affiliations will end up producing the same type of biographical criticism that Paul J. Smith denounced three decades ago (see the discussion in my Introduction). In this regard, the progressive ideology assigned to this set of three plays, a very common critical stand these days, results from a rudimentary interpretive strategy that basically consists in projecting Lorca's biography onto his dramatic works. I concur with Jonathan Mayhew, who has recently denounced that the "genuine admiration for the richness and variety of Lorca's work often shades into an uncritical sacralization of his authorial subjectivity . . . [that] leads directly to kitsch" (167). What makes Lorca a particular case, Mayhew continues, is that "the object of sacralization and kitsch is not a single work ... but Lorca himself, or, more precisely, the authorial subject as constructed in the Lorca myth" (169, his emphasis). Of all of Lorca's dramatic works, his agrarian plays stand out as the ideal works for the perpetuation of the Lorca myth. According to the most accepted version of the Lorca myth, the fictional events in Blood Wedding, Yerma and The House of Bernarda Alba unfold in remote geographies that are supposed to correspond to Andalusian villages whose ideological backwardness Lorca aimed to denounce. This is in spite of the absence of realistic signs to minimally corroborate this hypothesis-I am referring both to the dramatic texts and their first mise-en-scenes. In the particular case of Yerma, for example, when the play premiered in 1934, a number of critics could not identify its geographical and temporal settings, and some of them identified the landscape and the presence of certain animals, such as oxen, as eminently Castilian rather than Andalusian (on this debate, see Hernández "Cronología" 304-6). Alfredo Muñiz, in the Heraldo de Madrid, described the character of the Old Pagan Woman as "magnificiently Castillian.” In his review for $\mathrm{La}$ Voz, Enrique Díez-Canedo 
praised the secondary female figures, "full of native folkloric flair ... Castilian? Andalusian? No matter the accent, it will always be Spanish." A decade later, when Xirgu premiered The House of Bernarda Alba in Buenos Aires in 1945, critics perceived an intentionally abstracted geography (a play "without a determined location," La Nación, qtd. in Diago 154), favored the Castilian hypothesis ("the harsh geography of Castille," Francisca Chica Salas in Saber Vivir, qtd. in Diago 162), and defined Lorca's last play as a homage to Calderón, a play free of "picturesque elements" that stood out as an example of "authentic Hispanism" (in La Vanguardia, qtd. in Diago 164).

Continuing with the Lorca myth, the pattern of repression that Bernarda Alba exerts over her daughters is also a material that lends itself very well to anachronistic interpretations of the play, as it often occurs when The House of Bernarda Alba is read as an allegory of Francisco Franco's military regime. Theater scholars and practitioners who are unaware of the existence of the genre of the rural drama, and the importance of star actresses in Lorca's time, tend to overemphasize the role of contemporary politics in his tragedies. Discussing his own production of Blood Wedding in 2001, for example, director Roberto D. Pomo defined Lorca's play as one that "contains a strong statement with regard to the social conditions of its time, as Spain saw herself embroiled in a chaotic political whirlwind that culminated in a bloody civil war" (277). As Delgado has shown (112-3), international productions of The House of Bernarda Alba have routinely approached this play as a portrayal of Lorca's own death at the hand of repressive forces. These are political readings that only function retrospectively, of course, according to a logic that consists in interpreting Lorca's drama as one "in which his future death is at once anticipated and commemorated" (Smith Body 110). Temporal and geographical incongruities are listed to serve the cause, as was the case at the London's Gate Theatre production of The House of Bernarda Alba, in 1992, which featured the entire Alba family saluting "il duce" at the end of Act Two (Anderman 303; Delgado 112-3). In Spain, a number of recent productions, such as Jorge Eines' 1941, Blood Wedding, have distorted the most basic layers of meaning in Lorquian texts in order to convey the expected political message (for a list of incongruities of Eines' production, see Rafael Fuentes' review).

As noted above, the commonly accepted idea that The House of Bernarda Alba constitutes the third installment of Lorca's "rural trilogy" is the result of a posthumous editorial move. In this chapter, I still view the idea of an identity linking together Blood Wedding, Yerma and The House of Bernarda Alba, as the three works constitute modern rewritings of baroque honor plays. This does not necessarily mean, however, that the agrarian plays are the climax of Lorca's artistic progression. This teleological view has been applied to the trilogy itself but also, in retrospective mode, to all of Lorca's production. I disagree 
with the received idea that the tragedies "represent the culmination of all the character types, themes, and techniques that Lorca developed throughout his career. The plays are the result of artistic refinement and maturity" (Klein 9-10). A careful analysis of Lorca's writing activity from 1930 until his death in 1936 shows the absence of a linear pattern. Blood Wedding and Yerma are embedded between the earlier The Public and As Five Years Pass, one the one end, and The Dream of Life and the drawing-room drama Doña Rosita the Spinster, on the other. Of the very diverse projects he was entertaining in 1935-36, the first act of Dreams of My Cousin Aurelia, a continuation of Doña Rosita The Spinster, has survived (it only became known to scholars in the late 1980s, for an exhaustive analysis, see Torres "Del Teatro"). Moreover, as noted earlier, The House of Bernarda Alba is a play that stands on its own, the result of a very straightforward writing process that took place in spring and early summer of 1936 . Contrary to Lorca's customary practice of vividly describing the plots of his plays to friends and journalists even before beginning the actual writing process, he did not share The House of Bernarda Alba with members of his inner circle until he had the manuscript ready in late June of 1936 (Gibson 663), just a few days before the outbreak of the Spanish Civil War. It is worth noting, following a point raised by Andrew Anderson, that Lorca "was very much concerned" with the 'impossible' plays "throughout the 1930s, notwithstanding his other compositions or commitments," and that "he on occasions almost dismissed the plays of his which were produced" ("Strategy" 217, his emphasis). It is precisely because Lorca wrote for the contemporary stage that he was willing to adapt and react to its conventions and demands by trying with different formulas at the same time. In view of this reality, in this book I abstain from privileging one specific path. Instead, I propose a map of creative vectors within Lorca's dramatic production.

Lorca composed Blood Wedding in 1932 aware of the horizon of expectations set by a recognizable theatrical genre, the rural drama. This genre had its origins in the regionalist drama of Josep Feliu i Codina ( $\mathrm{La}$ Dolores, 1892) and Àngel Guimerà (María Rosa, 1894; Low Lands, 1896), whose peasant plays featured passionate female characters in recognizable parts of Spain. Playwrights who cultivated this genre made great emphasis on local customs, geography and folklore while also claiming to reflect regional dialect variation in what eventually became an artificial deformation of everyday speech catered to the bourgeois audiences in Madrid (see Paco 143-4 for an exhaustive list of recognizable linguistic traits typical of this genre). Benavente canonized the genre in Señora ama (1908) and The Unloved Woman (1913), and the genre was still popular in the 1910s and the 1920s thanks to playwrights such as José López Pinillos and Manuel Linares-Rivas (Paco 155-62). In 1927, Xirgu staged Marquina's The Hermitage, the Fountain, and the River, a rural play that enjoyed a run of more than one hundred performances. 
The existence of this genre explains Lorca's initial adoption of a certain set of characters, motifs and landscapes for his agrarian tragedies. In addition, both Benavente's The Unloved Woman and Marquina's The Hermitage, the Fountain, and the River contain collective scenes that precede similar ones found in Lorca's tragedies, particularly in Yerma.

In line with the approach I have adopted in this book, my aim is to discuss Blood Wedding and Yerma in the broader context of Lorca's contemporary theatrical industry. I cannot proceed in the same manner regarding The House of Bernarda Alba due to the fact that it remained unknown after Lorca's death in 1936 until Xirgu staged it in Buenos Aires in 1945. To demonstrate Lorca's willingness to initially accept the rules of the theater industry, I want to first discuss an extended preview feature of Blood Wedding that appeared in Sparta magazine four days before the play premiered in the Teatro Beatriz of Madrid. As a weekly entertainment magazine, this publication profited from a model that combined robust cultural reviews (theater, music, film), advertising of events and cosmetic products and a full calendar of cultural and sports events with information provided by the central office in Madrid and its branches in Barcelona, Valencia, Zaragoza and Lisbon (Nieva "La polémica" 13). The issue of March 4, 1933, included a one-page preview of Blood Wedding that featured an interview with Lorca, actress-impresario Josefina Díaz and playwright Eduardo Marquina. There are two aspects of importance in this text, signed by Felipe Lluch. First, Lluch portrays Lorca as "a poet, above all," an artist whose "strength" consists precisely in not being a "man of the theater." Lorca's alleged condition of outsider is emphasized to the point that he is described as somebody who is oblivious to "the tricks and mechanisms" of the theatre industry. Second, Lluch refers to Marquina as the de facto director of Blood Wedding. Marquina's involvement in the production is so crucial, Lluch argues, that it is difficult to distinguish between Lorca and him (the two "speak, confusing their thoughts ... because the collaboration is so intimate that it is no longer known who has put more affection in the work, Lorca or the director"). This testimony contradicts the accepted idea that Lorca was the sole director of the play. ${ }^{2}$ Additionally, the evidence corroborates the information published one day before, on March 3, in La Voz newspaper (Blood Wedding is presented as a play "under the joint direction of Eduardo Marquina and Federico García Lorca”).

It has become a common place to speak of Lorca's frustration with the cast of Díaz's company during the rehearsals of Blood Wedding, as most of the actors had little experience in tragic roles and little training in delivering verse, as his brother Francisco first observed (335; see also Gibson 539-40). If anything, I interpret this as an indicator of Lorca's willingness to tolerate what he might consider poor acting in order to escape the elitism of the Residencia group and connect with a broad commercial 
audience. Establishing a pattern that continued with Yerma a year later, Lorca avoided the "new versus old" dichotomy by negotiating his definitive incursion in the commercial arena. This did not only occur with Marquina, but with other representatives of the establishment. In the opening night of Blood Wedding, distinguished members of the Residencia circle (among them, Pedro Salinas, Jorge Guillén and Vicente Aleixandre) were predictably in the playhouse, sitting alongside a good number of young actors from La Barraca, fervent supporters of Lorca (Gibson 540). At the same time, it was possible to spot Jacinto Benavente and the Quintero brothers in the audience, the same authors who were the targets of Alberti's attacks in the premiere of his The Uninhabited Man back in 1931 and the incident mentioned in the previous chapter. Lorca's will to compromise with commercialism was obvious since Díaz's ensemble specialized in the Quinteros' light Andalusian comedies, a formula that had been enormously profitable for years-in the 1927-28, for instance, the Quintero brothers had 50 plays on stage in Madrid and premiered four plays, two of them reaching the number of 123 and 214 performances (see Dougherty and Anderson 295). ${ }^{3}$ This pattern continued in 1934, when the general rehearsal of Yerma constituted, as journalist José Luis Salado reported for $\mathrm{La} V \mathrm{Voz}$, a truly unprecedented event, one that gathered "a distinguished audience, something never seen before in these rehearsals" (Obras 550). Salado confessed to never witnessing "such a diverse crowd" (Obras 550) in a general rehearsal, an audience characterized by the contrast between Lorca's "entourage" of young admirers and the presence of three respected authors in their late sixties ("three distinguished beards") with very different trajectories in the theater. First, Benavente, leading representative of bourgeois drama and favorite target of avant-gardist groups in the 1930s. Second, Miguel de Unamuno, probably the greatest intellectual in Spain after Ortega y Gasset, and author of a corpus of philosophical theater with very reduced impact on the commercial scene. Third and final, Ramón M. Valle-Inclán, famous creator of the grotesque esperpentos and a controversial figure well known for his strained relationship with the theater industry. The year before, Lorca had defined Valle-Inclán's work as "mostly mediocre" while also condemning his admiration for Benito Mussolini after a recent stay in Italy ("he has returned a fascist," Obras 423). But now Lorca found a way, thanks to Rivas Cherif's intercession, to recruit the Galician author to publicly support Yerma. In his review of the premiere of Yerma, a day after the general rehearsal, Enrique DíezCanedo noted that not only did frequent theatergoers attend it, but the theater was also filled by "a different audience."

Going back to the preview of Blood Wedding in Sparta, the protective role of Marquina was evident when he declared his intention to make Lorca's Blood Wedding a commercial success. Marquina wanted it to become "the first play authentically written by a young author, in other 
words, new, that it comes with full force, with complete efficiency to the public." This statement reflects the harmony existing between Marquina and Lorca, as the older playwright was not simply sponsoring Lorca but, most importantly, he was defining him as someone who was in a very unique position-for the first time, Marquina argued that one of the "young," "new" authors could produce a full impact on the Spanish audience. It is highly significant that Marquina had participated in a quarrel between the old and new in 1931, less than two years before this open endorsement of Lorca. Marquina had defended the establishment playwrights (the so-called "putrefactos") by publishing an essay in response to Alberti's avant-gardist provocations in the opening night of his The Uninhabited Man. Marquina responded to Alberti on his own territory, the avant-gardist La Gaceta Literaria, in its issue of March 15, 1931, an episode discussed in the previous chapter of this book. Moreover, Lorca's Blood Wedding came out at a time when Marquina had recently brought to the stage a total of six rural dramas, all in verse, from 1926 to 1932. Marquina had returned to a genre he had abandoned around 1908. After Marquina's final rural play, Los Julianes (1932), Lorca adopted this genre for his own reformist agenda. His incursion in the genre of rural drama happened with the approval of Marquina, who defended this 'new' playwright in his search of a large audience. In favoring Lorca, Marquina was also protecting his artistic legacy ${ }^{4}$ as opposed to it being overshadowed by Alberti and other avant-gardist authors who took their aggressive rhetoric into the playhouses in the early 1930s.

The momentous year of the dethronement of King Alfonso XIII and the subsequent institution of a republican government in 1931 had been, incidentally, one of artistic realignment for Marquina. With the precedent of The Hermitage, the Fountain, and the River (1927), Marquina initiated a collaboration with Xirgu and Rivas Cherif that began with the production of The Hidden Fountain. This new rural drama premiered in the Teatro Español in January of 1931. María C. Gil Fombellida argues that Rivas Cherif became interested in Marquina's theater in verse because it suited Rivas Cherif's plan to combine innovative productions with commercial success guaranteed by a renowned playwright (173-4). This rural play, written in verse and located in Marquina's native region of Catalonia, constituted a great commercial success for the Xirgu-Rivas Cherif duo. With a run of more than one hundred nights, The Hidden Fountain was unanimously praised by the critics. A year later, in 1932, Xirgu and Rivas Cherif staged Marquina's The Julianes also in the Español. However, this rural play set in Castille only lasted a total of 40 nights and did not receive the same critical acclaim. ${ }^{5}$ The vitality of the genre of the rural drama was already coming to an end after almost four decades of existence. Signs of exhaustion were already evident in 1929, when theater critic José Luis Salado published a piece titled "Why Do All the Rural Dramas Look the Same?". A year later, previewing 
the upcoming 1930-31 theatrical season, critic J. González Catoyra sardonically announced that the spectators would get to enjoy plenty of rural dramas featuring conservative country men "who will spend most of the time talking about the harvest and comparing the earth with the female" (qtd. in Dougherty and Vilches La escena madrileña entre 1926 160). Each one of these plays, González Catoyra wrote, would end with a violent scene in which a man stabs his wife's seducer in the chest. In this context of Marquina's return to rural drama in 1931-32, Miguel García-Posada has described Blood Wedding as Lorca's adoption of Marquina's formula with the same purpose he had when he imitated the conventions of the other genre associated to Marquina, the historical drama, in Mariana Pineda. Lorca's decision to write Blood Wedding in late 1932, in the wake of Marquina's rural drama, was, according to García-Posada, Lorca's second "pact" (Introduction 12) with the commercial circuits. There was the added peculiarity that this time Blood Wedding also benefited from the popularity of Lorca himself, as the author of the book of poetry Gypsy Ballads. While García-Posada's description is accurate, it is also true that Marquina gravitated toward the Xirgu-Rivas Cherif and, indirectly, toward Lorca, for the reasons discussed previously.

One last aspect of interest in the Sparta preview of Blood Wedding involves its harsh final sentence in which Lluch announced his hopes about Lorca's play signaling the beginning of a new art "that should purge the stage from the rotting routine and mortal rigidity that, in these days, annihilates and drowns the theater." In late 1928, Lluch joined Rivas Cherif as assistant director and stage designer of El Caracol theater club, a chamber theater that Rivas Cherif had created to host a number of playwrights without access to the commercial stage of the time. On February 6, 1929, Lluch witnessed the governmental closure of the theater, on the grounds of pornography, while the rehearsal of Lorca's The Love of Don Perlimplin and Belisa in the Garden took place (on Lluch's design work for this production, see Aguilera and Lizarraga "Los tres" 116-8). With these final words, less nuanced that Marquina's, Lluch expressed his belief in a radical change of the Spanish theater industry. Lluch anticipated the critical discourse that Lorca voiced, more prominently, in 1935-36.

After studying a record number of 53 press reviews devoted to the three productions of Blood Wedding that Lorca saw staged in Spain (Díaz, Madrid, 1933; Membrives, Madrid, 1935; Xirgu, Barcelona, 1935), Fernández Cifuentes concludes that its overwhelmingly positive reception was something "surprisingly exceptional" (García 136), especially in view of the patent ideological divisions in the Spanish press during the years of the Second Republic. In addition to the political instability, the theatrical industry lived immersed in a state of crisis due to many factors (excessive dependence of a reduced number 
of playwrights, mostly authors of light comedies; abundance of revue spectacles; increasing popularity of cinema; these were constant topics of discussion in magazine Sparta in 1933-34, see Nieva "La polémica"). Fernández Cifuentes argues that the almost unanimous critical approval of Blood Wedding was due to the reduction of dialogues in verse, in comparison to Mariana Pineda. Lorca referred to this compositional method in terms of a new "formula" (Obras 411) in an interview held a few weeks after the premiere of Blood Wedding. In addition, by situating himself within the tradition of the genre of rural drama, Lorca was able to operate on secure ground, as the Madrid audience came to the playhouse already accepting the primitive nature of the rural figures in the play. Also, as Fernández Cifuentes observes, a good part of audience and critics took Lorca's book of poetry Gypsy Ballads as a form of fictional referent to situate the 'tragic' story of Blood Wedding (García 137-8). One last factor was that, in writing Blood Wedding as a partial recreation of a real crime widely covered in the national press in 1928, Lorca produced a certain reality effect that guaranteed a certain degree of verisimilitude. With all these controlling factors in play, Blood Wedding was praised by a group of critics who felt comfortable facing something that was not radically "new" (García 139-40). Lorca's second "pact" with the industry, therefore, was a matter not only of developing a different writing technique, but also of working within very specific performative signs that could be accepted by a general audience and a wide ideological spectrum of theater critics. Blood Wedding only needed two years (1933-35) to become Lorca's most produced play in his lifetime (for a detailed chronology of productions, see Edwards "Bodas"). In analyzing the success of Blood Wedding in Spain and Argentina, the existence of a set of generic conventions shared by Lorca and his audiences cannot be overemphasized. It is worth noting that the Buenos Aires audience that so positively judged Blood Wedding in late 1933 did so with the plays of Marquina, Benavente and the Quintero brothers in the immediate background. In the time Lorca spent in Argentina, from October 1933 to March 1934, Lola Membrives' company not only staged Blood Wedding, The Shoemaker's Prodigious Wife and Mariana Pineda but also produced four recent plays by Marquina (two historical dramas, St. Teresa of Jesus and The White Monk; and his rural dramas The Hidden Fountain and Los Julianes). The same company staged three of Benavente's dramas between late 1933 and 1934, among them Benavente's internationally renowned rural drama The Unloved Woman. In addition, the Andalusian comedies by the Quintero brothers were very popular in Buenos Aires, with three of them being performed in theaters of the city during the time of Lorca's visit (Larrea 92-4). This historical evidence shows that the positive reception that Blood Wedding had in Madrid and Buenos Aires in 1933 was due in great part to the spectators being equipped with an intertextual memory that put them 


\section{2}

on solid ground to then accept the "newness" (a term that recurrently appeared in the reviews of the Madrid premiere, Fernández Cifuentes notes, see his García 136-7) of the play.

Lorca's five-month stay in Buenos Aires and Montevideo is remembered in connection to Membrives' production of Blood Wedding, but Lorca's letters and press interviews from this period also contain valuable information about the making of Yerma. In February of 1934, for example, Lorca, who after the success of Blood Wedding felt entitled to hold the rights over the next installment of the rural trilogy, hid the manuscript-in-progress of Yerma from Membrives. It had been Membrives' idea to take Lorca out of Buenos Aires, where he enjoyed a status of local celebrity (Gibson 558-9), and seclude the Spanish author in a hotel in Montevideo with the hope of him writing the third and last act of Yerma. "She kidnapped me and brought me here" (Obras 507), Lorca declared in his first encounter with the press in Montevideo (on Membrives' orders to the hotel's concierge to not let visitors disturb Lorca, see Mora Federico 211-2). Contrary to Membrives' plan, however, Lorca wanted to have Yerma represented in the Teatro Español by Xirgu and Rivas Cherif once he returned to Spain that spring. In March, during his last days in Buenos Aires, Lorca offered a public reading of two scenes of Yerma and promised that the play would be finished in time to have it staged by Membrives in April (it is believed that at that point he tried to reach a compromise by encouraging two parallel productions in Argentina and Spain, by Membrives and Xirgu, respectively; see Hernández "Cronología" 296-7). While figuring out how to negotiate the egos and the financial interests of Membrives and Xirgu, Lorca was very aware of the importance of Yerma in securing his next move in the Spanish theater industry. Back in Spain, in July, while rehearsing with La Barraca before going out on a summer tour around the northern provinces, Lorca famously declared: "We must return to tragedy. Our theatrical tradition obligates us to do so. There will be plenty of time to make comedies, farces. Meanwhile, I want to give the theater tragedies" (Obras 536).

The tragic nature of Lorca's agrarian trilogy has constituted of a rich subfield of Lorca studies since the emergence and constitution of this scholarly industry in the 1960s. For half a century, critics have discussed such topics as Lorca's awareness of the general principles of the Aristotelian tragedy (Greenfield, for example, thinks Lorca lacked any theoretical rigor), the presence or absence of the idea of "poetic justice" (Gónzalez del Valle and Halliburton sustain opposite views), and the real existence of the element of the classic chorus in Lorca's plays. Blood Wedding, Yerma and The House of Bernarda Alba have been object to individual analysis numerous times. As early as 1962, for example, Calvin Cannon defined Yerma as the only Lorquian tragedy "in the classic sense," given that Blood Wedding is "pre-tragic," with characters that are "not 
heroes but unindividuated parts of ancient folkways" (85). Meanwhile, The House of Bernarda Alba constitutes, in Cannon's view, "a drama of sick people ... clearly akin to the ineffectual heroes of modern tragedy" $(85-6)$. There is no consensus as to the extent to which the most recognizable elements of Greek tragedy (hamartia, hubris, catharsis) operate in Lorca's agrarian plays. After numerous essays on the subject, it is up to the audience to accept that when Yerma kills her husband Juan "the Aristotelian catharsis is felt to the full" (Martínez 235), or, on the contrary, the ending of Yerma is characterized by "a sense of hopelessness" (Edwards "Way" 288; Edwards also extends this conclusion to the denouements of Blood Wedding and The House of Bernarda Alba). My aim is not so much to discuss the agrarian plays in connection to Aristotle, rather, to look at them through the lens of the baroque concept of honor. I see this as a logical response to Lorca's call, in 1934, to return to a specifically Spanish tradition ("our theatrical tradition"). One year before this explicit call to come back to the roots of Spanish tragedy, Lorca was already revealing the baroque substratum of his theater. In 1933, referring to the imminent premiere of The Love of Don Perlimplin and Belisa in the Garden, Lorca described Don Perlimplín as a grotesque figure whose struggle is not tragic precisely because he refuses to apply the honor code $^{6}$ of Calderón's wife-murder plays. In an interview with the Heraldo de Madrid, Lorca defined the play as

theater of human puppets, one that begins in mockery and ends in tragedy. The hero, or antihero, who is made the cuckold, is Spanish and Calderonian; but he does not want to react in a Calderonian manner, and therein lies his struggle, the grotesque tragedy of his situation. (Obras 406)

One can only speculate about what Lorca would have written had he not been executed by a fascist battalion on August 19, 1936. However, in the particular instance of The House of Bernarda Alba, there is enough evidence to assert that this play was more of a new beginning to him, rather than the third installment of the trilogy that featured his two greatest commercial successes Blood Wedding and Yerma. As many critics have noted before, Lorca's consistent use of prose in The House of Bernarda Alba constitutes a feature that distinguishes this latter play from its two predecessors This is an aspect that lends itself very well to progressive narratives, for it is easy to argue that as Lorca matured as playwright his trilogy evolved in form a la Henrik Ibsen, that is, from verse to prose. This was subject of discussion among the Argentinian critics who attended the premiere of The House of Bernarda Alba in Buenos Aires in 1945, with Samuel Eichelbaum being the first one in openly defending the idea that "Lorca's posthumous work represents a victory of the playwright over the poet" (qtd. in Diago 159). Also, from a compositional 


\section{Writing for the Stage}

standpoint, there is a second aspect of The House of Bernarda Alba that needs to be considered here. I am referring to its condition of 'drama,' as opposed to tragedy, a structural marker Lorca himself indicated in the play's subtitle, "A Drama of Women in the Villages of Spain." The genre that Peter Szondi defines as "drama" 7 was dominant in Europe until the rise of subjectivism in late nineteenth century. The subjectivistic trend was exemplified by Strindberg's dream plays, "a sequence of scenes whose unity does not reside in the action but in the unchanging psyche of the dreamer, who is, perhaps, the hero" (Szondi 28). Maurice Maeterlinck's static plays constitute another example of a type of theater far removed from the idea of action as result of present, interpersonal, events. The early decades of the twentieth century witnessed the proliferation of montage techniques and the partial displacement of mimesis by diegesis (see Puchner Stage), crystalizing into what Szondi refers to as the "epic I" that culminates in Bertolt Brecht's own version of "epic" theater (Szondi 6). A good part of Lorca's dramatic production contains mediating figures such as fictional authors and directors as well as characters who play the role of commentators, and in terms of subjectivist aesthetics one can recognize The Public as the most daring exercise in interwar Spain. In contrast, The House of Bernarda Alba maintains itself strictly within the confines of nineteenth-century realist drama, operating under the principles of unity of action and space. In The House of Bernarda Alba, Lorca solved the temporal transitions by means of three self-contained acts with two ellipsis that create the illusion of contiguity. Everything occurs in the present, without flashbacks or flashforwards, and without any type of subjective perspectivism.

Discussing the absence of tragic metabasis, or hero's change of fortune, in The House of Bernarda Alba, Gina Beltrán argues that this work is a drama-and, I would add, a drama in the Szondian sensesince "its plot is self-contained . . . there is not metabasis because nothing changes for better or for worse; instead, the closed structural construction of the play ensures that the play ends at the same point where it started" (39). As Beltrán rightly observes, the play opens with Bernarda Alba demanding "silence" instead of tears, and imposes an unrealistic period of eight years of mourning over the death of her second husband. The play ends with the same call for "silence" after the suicide of her youngest daughter Adela is revealed, and Bernarda telling her daughters to contain their tears and prepare themselves to "drown in a sea of mourning" (House 78). Beltrán also notes that in The House of Bernarda Alba "the dramatic space corresponds to the private space, while in Greek tragedy it constituted the public space. This indicates that Lorca's play is not a political happening, like Greek tragedy, but instead a domestic drama" (40). Bernarda processes the death of her second husband, and the death of Adela, as strictly domestic issues (the idea of receiving people at her husband's funeral disgusts her, as she expresses in 
Act I: "They've trampled all over [the floor] like a herd of goats," House 12). This is the complete opposite of the inherently social affair that was the result of the Bride running away with Leonardo in Blood Wedding. It is also a situation radically different to Yerma's taking her frustration to the public sphere, asking the Old Woman for advice, visiting a sorcerer and, finally, joining barefooted women in religious pilgrimage (her husband Juan has recruited his two unmarried sisters to unsuccessfully keep her at home). In Yerma, the protagonist's public plea escalates to the point that she ends up strangling Juan on the mountain where hundreds have gathered in pilgrimage.

Bernarda's obsession to maintain her daughter's passions within walls resembles a modern version of what William Egginton defines as "the baroque house" represented in several of Cervantes' novellas, among them The Jealous Extremaduran (1613). In this text, the insanely jealous character of Felipe Carrizales intends to protect his young wife Leonora by placing her in a house with two walls, of which the interior space can only be accessed by virgin women. Yet, it is precisely all these precautions that ends up sparking the curiosity of a male seducer (a virote, someone with strong sexual power, a figure similar to Pepe el Romano in Lorca's play). In his reading of Cervantes' novella, Egginton observes how "the physics of baroque architecture decree that the very walls that one doubles up, in the interest of protecting an interior purity, have the intensely disturbing effect of rendering that interior space impure" (Theater 30). The very title of Lorca's last play highlights the importance of the house as the materialization of Bernarda Alba's desire to fully insulate her daughters from the sexually aggressive males in town. In the opening scene, Bernarda has only allowed women to enter the house to attend the funeral, yet the threatening presence of the men is still felt as they gather outside and openly discuss sexual matters. "There she was behind the window listening to the men's talk. Filth, of course. None of it worth listening to" (House 16), says the housekeeper La Poncia when she finds Angustias, Bernarda's eldest daughter, listening to the men by her bedroom's window. La Poncia then reports to Bernarda that the men were openly talking about last night's episode involving Paca La Roseta: "Last night they tied her husband to a cattle trough and took her off to the olive grove" (House 16). In Act II, La Poncia tells the daughters about the arrival of the harvesters: "Far away. From the mountains. They're full of joy! They sing and throw stones! And yesterday a woman came. She had sequins all over her dress and she danced to a tambourine. Twenty of them made a deal with her and took her to the olive grove. I watched them" (House 41). When Adela proposes to her daughters to watch the reapers from the window of her room, La Poncia advises her to not open the window ("Open it just a crack and they'll push it open wide," House 43). This climate of moral degradation is what Bernarda attempts to combat by preventing any contact between 
her daughters and the exterior. As she puts it in the opening scene, "We will brick up the doors and board up the windows. We won't let in a breath of air from the street . . . Mourning will last for eight years" (House 13). In the end, Bernarda's baroque house will not resist all the external threats, and Pepe el Romano becomes the man who causes the final destruction of the Alba family.

An analysis of how an internalized code of honor determines the actions and behaviors of certain characters in the agrarian plays can also shed light on a question that was widely discussed since the moment Lorca premiered Blood Wedding in Madrid in 1933. I am referring to his symbolic technique of characterization, one that in the case of Yerma borderlines the allegorical mode. The critics who reacted to Blood Wedding and Yerma tended to interpret Lorca's shift from realism (as codified in the genre of rural drama) to symbolism as a dominance of the poet over the playwright. They praised Lorca and Marquina's production of Blood Wedding yet expressed reservations about the change of registry in the scene that opens the third act of the play. In a fantasy forest, still in the same night of the wedding, the Bride and Leonardo express their love in a highly poetic verse. The couple is surrounded by three symbolic characters (the Woodcutters, the Beggar Woman and the Moon) that foreshadow ${ }^{8}$ the deaths of the two men, Leonardo and the Bridegroom, in a knife duel that takes place offstage. Critic José de la Cueva described Blood Wedding as a "drama that logically leads to inevitable catastrophe," but objected to Lorca's use of symbolic characters in the third act, a decision he attributed to "the poet" in Lorca. In his review for Informaciones, based on his impressions of the general rehearsal, de la Cueva lamented that this ruined the "marvelous sensation of horror that [the play] had already awoken within us," and concluded that Lorca's first incursion in the genre of rural drama was a "frustrated tragedy, undone drama . . . but its fragments value the worth the whole of the perfect play." The day after the premiere, a second theater reviewer, this time for $A B C$, celebrated Lorca's talent for characterization ("Some principal characters could be torn from Sophocles' pages"), in agreement with de la Cueva, who had celebrated the "three central types" of the Mother, the Bride and the Bridegroom. The $A B C$ reviewer also endorsed the simplicity of the play's plot yet he deemed the third act "inferior to the other, because the appeal to the poetic symbol is exaggerated."

Lorca, aware of this criticism, quickly reacted in an interview published scarcely one month after the play's premiere. His favorite moment of Blood Wedding, Lorca declared, was precisely "when the Moon and Death intervene, as motifs and symbols of fatality. The realism that presides the tragedy until that instant suddenly breaks and disappears, giving way to the poetic fantasy" (Obras 412). The presence of the terms "realism," "tragedy," and "poetic fantasy" in the same sentence was indicative of Lorca's struggle to define, and defend, his technique of characterization 
in Blood Wedding. From The Butterfly's Evil Spell (1920) and Mariana Pineda (1927) up to Blood Wedding, he had been categorized as a lyrical talent with insufficient dramatic skills - the preview in Sparta went even further, portraying him as an outsider with no knowledge of the ins and outs of the theater industry. By resorting to the fuzzy concept of "poetic fantasy," Lorca was attempting to justify, unsuccessfully, his tendency to merge realist and abstract patterns of characterization. In the case of the forest scene in Blood Wedding, my thesis is that its writing was influenced by Lorca's experience as reader and director of Calderón in the summer of 1932, at the very same time when he worked on his first tragedy. That summer La Barraca began its travels around Spain with visits to eighteen different towns featuring its first repertoire, consisting of four interludes by Cervantes and Calderón's auto sacramental Life is a Dream. Lorca initially chose to program Cervantes' comic playlets and Calderón's allegorical play to address two different audiences, a "popular" and a "more limited spectatorship," respectively, as stated in an internal memorandum of La Barraca. ${ }^{9}$ Lorca's attraction for Calderón's allegorical characterization-Lorca famously played the role of Shadow when he staged Life Is a Dream before political authorities in Madrid in late 1932-provides a background to understand his defense of the 'fantastic' figures of the Moon and the Death (Old Beggar) in Blood Wedding. When Yerma arrived in Valencia in November of 1935, after sensational runs of the play in Madrid and Barcelona, Lorca was in a better position to verbalize Calderón's influence. "The root of my theater is Calderonian," he declared to the press in Valencia. Lorca defined the pilgrimage scene that ends Yerma as an exercise of transition "from the real to the symbolic real," one that creates, very much in alignment with Calderón's allegorical technique, "embodied ideas" (Obras 612).

With Yerma, Lorca took the simplicity of the plot that characterized Blood Wedding one step further. In declarations to the press on the inaugural day of the Barcelona production, on September 17, 1935, Lorca defined Yerma as "a play that has no plot" (Obras 582 and 583). He announced "a tragedy, pure and simple" (Obras 583), one to revolve around a single "theme," Yerma's maternal obsession. Barrenness, he insisted, was a theme, not a plot (Obras 582). It was not simply a matter of simplifying the intrigue, but also of reducing the main character's psychological depth. This second aspect, the psychological design of Yerma, remains an issue consistently ignored by scholars who propose politically progressive, if not revolutionary, readings of this female figure. In early 1934, when asked by the Uruguayan press about his common practice of writing roles for actresses, Lorca explained that "women are more passionate, they intellectualize less, they are more human, more vegetal [más vegetales]" (Obras 501). From today's perspective, these words do not stand out as feminist, one of the central traits ascribed to the Lorca myth, and it is not surprising that scholars have consistently 


\section{8}

avoided discussing this very important statement from early 1934 . What I propose is a reading of Lorca's words not in absolute terms but, rather, in the context of his full commitment to the genre of rural drama between the years of 1932 and 1934. Once again, I am approaching the theory and practice of Lorca's theater putting them in the perspective of the theater industry of his time. My view is that Lorca's words about the female psyche matched well with the principles of the dramatic genre he was adopting - and adapting - to finally gain the favor of the theatergoers. Since its beginnings in the last years of the nineteenth century, as Mariano de Paco notes, the rural drama was a genre "made by and for the bourgeoisie," one that identified the Spanish peasantry with "clearcut models of behavior, innocent sentiment and rudimentary ethics" (142). This dramatic genre relied on the contrast established between the psychological primitivism of its characters and the more 'civilized' status of the theatergoers who lived in urban areas. Lorca's words acquired a sense of coming from someone who, at one point of his life, was willing to accept this dichotomy. This interview from 1934 also offers an important clue about Lorca's interest in writing roles for female figures, as he confessed it would be "very difficult" (Obras 501) for him to access the stage with plays featuring strong male roles. While the official version he gave to the Uruguayan press was that there was a lack of "good actors" (Obras 501) in Spain, he was perfectly aware of the fact that the way to conquer the commercial scene was through the actress-managers. The tailoring of roles for certain actors and actresses had been denounced by such theater critics as Enrique Díez-Canedo and Luis Araquistain for two decades in Spain (Jiménez León 281). In the 1930s, the rule of actress-managers was so dominant that Díez-Canedo concluded, in a 1935 piece for La Nación, that playwrights "must write tailor-made roles for star actresses, or resign themselves to never seeing staged what they have written."

After the big success of the Madrid production in the first half of 1935, Lorca had numerous opportunities to explain Yerma while touring Barcelona and Valencia, accompanying Xirgu and Rivas Cherif, in the fall of 1935. In Valencia, in November, he declared himself most proud of depicting Yerma's "obsessive process" [proceso obsesivo] in a way in which she "talks in the same way from the moment she enters until the moment she leaves the stage" (Obras 613). This reference to Yerma's "obsessive process" echoed what had become a recurring term in the newspapers of Madrid and Barcelona, prone to describe Yerma as an "obsessive" and "pathological" figure (see excerpts from reviews in La Época, Diario de Madrid, Informaciones, among many other news outlets, in Fernández Cifuentes García 163-4). Taking up a subject he had commented on in early 1934, while still working on the play in Argentina and Uruguay, Lorca now presumed of being "deliberately careful to eliminate all evidence of mental elaboration" (Obras 613) in 
Yerma. Lorca also justified his decision of portraying Juan as a "weak man" in order to avoid a true conflict materializing in "a problem play" that would oppose his view and Yerma's (Obras 613). This description of Juan as a weak individual who cannot interact or enter in true dialogue with his wife Yerma was indicative of Lorca's will to not write a drama based on interpersonal relations but rather a symbolic play with very attenuated action. When Yerma premiered at the Teatro Español of Madrid on December 29, 1930, its simplicity was object of debate. A.C., author of a negative review for $A B C$ newspaper, opened his text acknowledging the uniqueness of Lorca's play, "one that cannot be judged according to today's theatrical standards." The critic found fault with the lack of dramatic progression in the play, arguing that only its third and last act contained true "dramatic incidents." In the Heraldo de Madrid, Alfredo Muñiz held the opposing view by defining Yerma as "a symbol" that, as such, is forced to irremediably follow the tragic trajectory that has been established from very beginning. When Yerma opened in Barcelona, in September of 1935, María-Luz Morales wrote in La Vanguardia that Lorca's play was "another world, beyond exposition, rising action, climax, resolution, and other nonsense ... [Lorca] manages to elevate characters, passions, ambiance, until they reach abstraction, without losing the human touch." The play, Morales observed, consists of one long "painful monologue" by Yerma, while the rest of the characters stay in the background.

To conclude this chapter, I now propose a brief reflection on the concept of honor in the agrarian plays with a special emphasis on its thematic implications as inferred from a reading of the three dramatic texts that is not necessarily predetermined by feminist positions well in tune with the myth of Lorca as a revolutionary playwright. The idea of a type of social pressure asphyxiating the Lorquian heroines has been repeatedly explained through the ascendance of Catholicism in Lorca's contemporary society. Gibson, for example, states that Yerma's sense of shame is due to "the severity of Spanish Catholicism" (550). In a similar vein, Bilha Blum has recently argued that the figure of The Mother in Blood Wedding "embodies the renunciation of the desire for happiness as elaborated by Christianity ... endemic in 1930's Spain" (85). According to this logic, the female heroines in Lorca's tragedies are supposed to fight Catholic values and social conformity embodied by such oppressive characters as the Mother in Blood Wedding, Juan in Yerma and, of course, Bernarda Alba. Roberta Johnson summarizes this position when asserting that Blood Wedding "centers on a marriage arranged for reasons of social class and economics" (262-3). Johnson states that, in addition to this theme, Yerma and The House of Bernarda Alba foreground social issues such as "women's confinement to the home" and, in the specific case of Yerma, "the importance of the divorce legislation that was promulgated [in Spain] shortly before the play was written" (263). 
As a consequence of these premises, if a play such as Blood Wedding remains topical today it is because it denounces the unfairness of arranged marriages. However, as I have argued elsewhere in this chapter, I disagree with the idea that Lorca's agrarian trilogy should contain a set of messages to be defined as politically reformist, not to mention revolutionary (the latter would be the case of The Dream of Life, for example, but not of the tragedies).

Jesús García Maestro, who distinguishes three anthropological axis of human existence (the political-social, the natural, the religious), observes that Lorca's tragedies do not operate in the realms of the political or the religious. Rather, he argues, they function in a natural space that is foreign to anthropological and theological reasons alike. Lorca's thought, García Maestro posits, is "passionate, natural, instinctive, Nietzschean" (17). His tragedies present not some kind of formalized political message, but "human passions in their most elemental and irrational state" (18). In his discussion of the particular case of The House of Bernada Alba, García Maestro observes that there is nothing feminist about a group of single women willing to betray each other in order to copulate with a man, Pepe el Romano, who is basically the only male figure that their mother allows to be in the vicinity of house. In this regard, there is one passage I consider to be of special relevance when assessing the allegedly feminist message of The House of Bernada Alba. Adela, Bernarda's youngest daughter, often romanticized as the heroine of the play because of her final suicide, verbalizes her evident sexual submission toward Pepe el Romano. As she states in a heated dialogue with her sister (and rival for Pepe's sexual favors) Martirio: "He can marry Angustias. I don't care anymore. But I'll go off to a lonely little house and live there so he can see me whenever he wants to. Whenever he needs to" (House 74). Adela's blind submission to such an essentially masculine figure like Pepe is not an action that creates a space for progressive sexual politics. Moreover, because Lorca operates at the deepest, or simplest, biological level known to us, what unfolds within the walls of Bernarda's house is not a feud between sisters but a full-fledged Darwinian struggle. The latent presence of Pepe ends up destroying what we regard as the most elementary ties between the sisters, those of kinship, in the third and last act of the play ("We're not sisters anymore," 73). From the same standpoint, the case of Blood Wedding is even more disconcerting than The House of Bernarda Alba. The general opinion is that in this play Lorca vehicles a feminist message by portraying a Bride who confronts the social norms of contemporary rural Spain. She does so by refusing to marry the Bridegroom and running into the woods with her true love, Leonardo, who incidentally is the only character individualized with a name. As Linda Materna observed three decades ago, the reason why the Bride never married her former lover Leonardo is as simple as his modest upbringing (Materna 268). Leonardo recriminates to her in their 
first dialogue in Blood Wedding: "Two oxen and a tiny house are worth almost nothing. But that's all I had. That's where it wounds me" (Blood 35). According to this mercantile logic it would be Leonardo himself, and not the Bride, the one who should be considered the main victim of social conventions. Moreover, in today's political terminology, it is hard to find a female character that shows less agency than the Bride, who ends up running away with Leonardo because "Oh, this is such madness / . . / Because you drag me along / And when you say 'Go!' / I go" (Blood 70). Materna explains in very clear terms how the Bride embodies a traditional depiction of female figures as irrational beings whose sexual identity exists in contrast to archetypal men. While repressed sexual desire is the cause that makes Lorca's female characters fight against authority figures, one must bear in mind that these burning passions only drive these women to offer themselves in sacrifice to the "natural" dominance of the male, as Materna notes (271-2). The perfect dramatization of this idea is found in the third and last act of The House of Bernarda Alba, in the exchange that takes place between Bernarda and Adela after it is revealed that Adela has had sexual intercourse with Pepe el Romano. Bernarda fiercely approaches Adela, who then reacts: "This is when your judgments end! (Seizes her mother's stick and breaks it.) So much for the oppressor's stick! Don't you dare come close to me. No one has any power over me now. No one but Pepe!" (House 75). Adela, the same person who previously revealed to one of her sisters her decision to leave the family house and establish herself as Pepe's mistress, finally verbalizes the full extent of her actions. She tells her mother that she will only accept the tyranny of a man.

In The House of Bernarda Alba, Adela eventually commits suicide believing that her mother has killed Pepe el Romano. The opposition between a young heroine (Adela) and an oppressive figure with proto-fascist traits (Bernarda) seems obvious at first sight. However, as Isaac Benabu argues (136-8), a dramatic character like Bernarda Alba is not a masochistic dictator but rather a figure of tragic stature who witnesses, with impotence, how her world crumbles. When the play opens Bernarda is widowed for second time, impoverished, struggling to maintain alive the past glory of the Alba dynasty. She is aware that four of her five daughters are unmarriageable unless she accepts to give them away to the villagers she despises (only her eldest daughter, Angustias, has a dowry to offer; this is precisely the reason why Pepe el Romano has been courting her). In Act I, Bernarda, offended by La Poncia's insinuations about the age of her daughters, declares: “There's no one within a hundred miles of here who can touch them. The men here are simply not of their class. Do you want me to hand them over to some farmhand?" (House 18). ${ }^{10}$

In Calderón's tragedies, in particular those that bring to the foreground the concept of honor (Secret Insult, Secret Vengeance; The Physician of His Honor; The Painter of His Dishonor), the main character never dies. 


\section{2}

Instead, Benabu notes, this character "is condemned to a life of suffering and silence" (130). A review of the ending of the three tragedies confirms Benabu's theory on the nature of Lorca's tragic drama. In The House of Bernarda Alba, Adela's suicide condemns Bernarda, and her daughters, to an irreversible social death. In Yerma, she eventually kills her husband, sabotaging the only biological path to conception that she is willing to accept, as Yerma's honor makes her refuse any proposal from other men. In Blood Wedding, the Mother ends up mourning in silence the death of her second son, the last male in his family. The Mother refuses to punish the Bride even though she offers herself in sacrifice for the violence she has caused. In accordance with Benabu's main point, it can be asserted that these three denouements are strictly calderonistas in the sense that they form part of tragedies that do not portray the killing of those figures who are guilty of moral errors. I am particularly interested in one related aspect, namely how the characters' actions in the agrarian plays are determined by the baroque idea of honor that they have internalized so dearly. From the perspective of the cohesiveness of the fictional worlds created by Lorca, the results are unequal, for in some cases the external manifestations of the characters' internal code of values come up as contradictory. Predictably, this occurs in Blood Wedding, Lorca's first attempt at creating the 'formula' of a new rural drama. To prove my point, I will now quote extensively from the climatic dialogue between the Bride and the Mother in the last scene of the play:

BRIDE. Because I went with the other one, I went! (Full of anguish.) You would have gone too. I was a burnt woman, full of wounds inside and out, and your son was a little drop of water from whom I expected sons, land and health; but the other was a dark river, full of branches, who brought to me the sound of his rushes and the singing between his teeth . . . I did not want it. Listen to me! I did not want it. Your son was my goal and I never deceived him, but the arm of the other dragged me on like waves of the sea and would have dragged always, always, always, even though I had been an old woman and the sons of your son dragged me back by the hair! (Blood 80). ${ }^{11}$

This speech reveals, very transparently, the Bride's complete lack of agency. Immediately after these words, however, she invokes her honor to frontally defy the Mother to a duel of purity: "I am honorable, as honorable as a newborn child. And strong enough to prove it. Light a fire. We'll put our hands in the flame: you for your son, me for my honor. And you'll take yours out first" (Blood 81). This is an implausible turn of events, as the Bride stands out as a character who justifies her being dragged by the powerful sexuality of the male ("I did not want 
it") and, at the same time, she boasts about her virginity in a way that includes a public challenge to the mother of the man who was supposed to be her future husband. Scholars who defend feminist interpretations of Blood Wedding systematically disregard the contradictory nature of the Bride's behavior. Johnson, for example, ignores these controversial aspects in order to present the Bride as an empowered woman who, in Johnson's words, "prefers to risk all by running off with Leonardo immediately following the ceremony" (267, my emphasis). The speech I quoted above contains no indication of the Bride being in a position to 'prefer' anything, quite the contrary. Johnson also argues that despite the fact that her elopement with Leonardo triggers the deaths of the two men, "Lorca provides her the opportunity to vindicate her actions and garner the audience's sympathy with several lengthy speeches at the end of the play" (268). I also remain skeptical about this idea. Similarly to Johnson, María T. Vilches de Frutos interprets the final confrontation between the Bride and the Mother in terms that are patently favorable to the former at the expense of ignoring basic textual evidence. "Despite the misfortune," Vilches de Frutos explains, "with courage the Bride defends her actions to the Mother" (20, my emphasis). This idea of the Bride acting 'courageously' before the Mother is simply inaccurate and has no place in this scene.

In the case of Yerma, the honor code to which the protagonist so firmly adheres to represents an ideological discourse that she proudly internalized years after getting married to Juan. Yerma uses, on repeated occasions, the term "mi casta." This noun, frequently translated by "my kind," "my lineage" or "my family," also contains, potentially, the social implications of "my caste." In the second scene of Act II, Yerma brings up the superiority of her "casta" when she complains to her friend María about the presence of Juan's two sisters in the house: "They think I might be attracted to another man, and they've no idea that even if I were it's decency that comes first in my family" (Yerma 101) [lo primero de mi casta es la honradez]. In the first scene of Act III, Juan, accompanied by his two sisters, finds Yerma visiting Dolores the healer. He is worried about the gossip around her, yet Yerma replies to him by invoking the purity of her blood lineage: "You and your kind imagine that you are the only ones who have a reputation ["honra"] to look after, and you don't realize in my family [" $m i$ casta"] there's never been anything to hide. Come on. Come here and smell my clothes; come here! Try to find a smell that's not yours, that's not from your body" (Yerma 115). According to Pilar Nieva, the problem affecting Yerma is that she is caught up in a situation in which "her husband cannot provide her children and she cannot have them with another man, outside of the marriage" ("Identidad" 160). This is a very controversial statement in view of the fact that Lorca provides no indication whatsoever about who is to blame 


\section{Writing for the Stage}

for Yerma's inability to conceive. If anything, the signs point toward her (in the second scene of Act II, Juan accuses her of not being "a real woman" [una mujer auténtica]; in the first scene of Act III, Yerma confesses to the old woman Dolores that "he does his duty by covering me in bed, but his body feels cold and lifeless against mine" (Yerma 111). In addition, the idea that Yerma cannot have a child out of the wedlock due to societal constraints is not completely accurate. When in the final scene of the play Yerma refuses the offer from the Old Pagan Woman ("My son is sitting waiting for you behind the shrine. Our house needs a woman. Go to him and the three of us will live together," Yerma 129), a mimetic interpretation of Yerma's actions results insufficient. According to Nieva, for example, the reason for Yerma's rejection of the proposal to have sex with another man is that she is "very aware of what her social status would have been as an adulterous woman" ("Identidad" 168). Yerma, however, has internalized the ideology of the honor code to the extreme that the idea of looking for a second man seems 'unnatural' to her. Yerma's proud speech shows no indication of fear a potential social backlash:

I can't go out looking. Do you seriously think I could sleep with another man? What about my honor? Water can't flow uphill, and the full moon can't shine at midday. Get out of my sight, I'll go my own way. Do you really think I could submit to another man? Go groveling to him for what's mine, like a slave? $\left(\right.$ Yerma 129) ${ }^{12}$

Honor and caste stand out as the central motives for Yerma's actions. She eventually fulfills her destiny when she chokes Juan to death ("Barren, barren, but now I'm certain!", Yerma 133), in strict correspondence with the portrayal that Lorca made of her when the play premiered in Valencia, in November of 1935. Yerma, Lorca asserted, "has a limited freewill because she is chained by the concept of Spanish honor, a concept that runs through her veins" (Obras 614).

\section{Notes}

1 Xirgu and Rivas Cherif had developed a close relationship with the authorities of the Second Republic. Its first Prime Minister, Manuel de Azaña, was a longtime friend and collaborator of Rivas Cherif who became his brother-inlaw when Azaña married his sister in 1929. In 1932, Xirgu and Rivas Cherif staged Azaña's play The Crown.

2 Gwynne Edwards considers the first production of Blood Wedding "particularly interesting because its director was Lorca himself, and the production therefore provides valuable evidence of the way in which he wanted to see his plays staged" (470). This statement needs to be partially rectified to account for Marquina's involvement. 
3 In an interview from August 1933, a few months after this first production of Blood Wedding, Lorca openly criticized the theater of the Quintero brothers, distancing himself from their Andalusian comedies (Obras 423).

4 St. Teresa of Jesus (1932), a historical play assembled as a sequence of lyrical tableaux, was Marquina's last notorious success in the Spanish stage. The role of St. Teresa was enacted by Lola Membrives, the same actress who took Lorca's Blood Wedding to Argentina a year later. When the Spanish Civil War broke on July 18, 1936, Marquina was in Argentina. There he published literature supporting Franco's side to eventually return to Spain in 1938. Marquina passed away in New York, serving in diplomatic mission, in 1946.

5 See Gil (174-8) on the critical reception of Marquina's The Hidden Fountain and The Julianes.

6 The idea that a baroque code of honor is present in Lorca's agrarian plays was not accepted without resistance from one part of the Lorquian industry. In the early 1970s, Luis González del Valle defined Arnold G. Reichenberger's brief incursion in the arena of Lorca studies-a two-page argument on the "universality" of Lorca embedded in a larger discussion on the "uniqueness" of the Spanish comedia- as "deplorable" [lamentable] (238n7). González del Valle, a twentieth-century critic with special interest in Lorca, accused Golden Age scholar Reichenberger of not being equipped to make an excursus outside his period of specialization. Reichenberger had defined honor in Lorca's tragedies as "the great superhuman power which drives the protagonists to destruction” (165). Gónzalez del Valle affirmed that if bad things eventually happen in Blood Wedding, it is due to the Bride's moral flaw that makes her escape with Leonardo the night of her wedding. Honor, according to González del Valle, has no relevance whatsoever in triggering the action (the Bridegroom chasing the Bride and Leonardo resulting in both men killing each other in a duel). González del Valle's aggressive stance against Reichenberger constituted one of the first cases of disciplinary territorialism exerted by critics ascribed to the Lorca scholarly boom.

7 Szondi's definition of what he conceptualizes as the modern genre of "drama" includes a list of features that correspond, one by one, with Lorca's The House of Bernarda Alba. I am listing, very briefly, the following characteristics from Szondi's classic study Theory of the Modern Drama: Dominance of dialogue that reflects the "reproduction of interpersonal relations" (8); existence of an illusionistic frame ("It can be conscious of nothing outside itself," 8), with no intrusions from the dramatist; complete separation between spectators and the stage, although spectators can identify themselves with the characters speaking; illusionistic acting ("the actor-role relationship should not be visible," 9) and, finally, an action that always takes place in the present ("time unfolds as an absolute, linear sequence in the present," 9), and primarily in the same space.

8 Edwards has referred to a "sense of inevitability" that is reinforced "by a network of specific references and allusions to fate and destiny" throughout the three agrarian plays. It is his view that Blood Wedding, Lorca's first tragedy, is "both the most explicit and the most theatrical, for in the final act the three axe-wielding woodcutters, the fearsome figures of la Luna [Moon] and la Muerte [the Death, represented by the Beggar Woman], and the girls' unwinding of the ball of red wool, become the physical manifestations of those fateful and fatal forces at work upon the human characters" ("Way" 283). 


\section{Writing for the Stage}

9 See excerpt from the document from early 1933, first reproduced by Sáenz de la Calzada in the 1970s, in Huerta "Cervantes" 5.

10 In this dialogue, Poncia confronts Bernarda and exposes the social implications of the gradual impoverishment of the Alba family:

LA PONCIA. You could have looked in another village.

BERNARDA. Oh yes, and sold them!

LA PONCIA. No, Bernarda. Not sold them. Married them ... Of course, in other places it might be you who'd look poor!

BERNARDA. Shut that vicious mouth of yours! (House 18)

11 I have modified the translation slightly. My translation of the original "yo no quería" is "I did not want it," instead of "I never loved him," as Clifford proposes.

12 I have modified the last sentence of the translation by Macpherson and Minett in order to highlight the noun "slave" [esclava] that appears in Yerma's refusal ( ¿Qué yo vaya a pedirle lo que es mío como una esclava?”). 


\section{Epilogue}

Throughout this book, I have argued against the consideration of Lorca's agrarian trilogy (Blood Wedding, Yerma and The House of Bernarda $A l b a)$ as the culmination of his trajectory in theater. This is a critical common place that results from a predominantly biographical interpretation of Lorca's work that presents his incursions in the theater as a steady progression until the time of his death in 1936. To provide a more complex picture of Lorca as playwright, the first two chapters of this book have focused on the different ways through which Lorca problematized the theatrical stage in the 1920s. In Chapters 3 and 4, I have studied The Public and The Dream of Life, two iterations of the "impossible theater" that Lorca repeatedly discussed in the 1930s. Claiming the importance of these two plays, however, does not necessarily mean that they should receive more critical attention than the agrarian plays. In recent past, there have been scholars who have substituted one set of central plays with another, yet this alleged transgressive move has not resulted in any substantial gain as it basically perpetuates the center/periphery logic. One example is María Estela Harretche's chapter on Lorca in Huerta Calvo's History of Spanish Theater (2003). Harretche abandons the most basic chronological description to instead engage in a detailed discussion of three plays Lorca referred to as "impossible"-The Public, As Five Years Pass and The Dream of Life. She devotes thirty of the forty pages that form this chapter to these three dramas, to the detriment of the rest of Lorca's theatrical production. ${ }^{1}$ However, as I have demonstrated in this book, the complexity of the Lorquian dramatic corpus invalidates one-sided theories, and swinging the pendulum from one extreme to the other is not an adequate solution. Because Lorca wrote theater to see it staged, he often found himself exploring multiple paths simultaneously. Lorca depended heavily on external agents, such as the actress-managers that dominated the theater industry in Spain, and especially in the late 1920s and early 1930s he also had to navigate between two opposing forces: the avant-gardist circles and the representatives of the artistic establishment.

Much has been written about the afterlife of the manuscripts of Lorca's dramatic works. As noted earlier, he only cared to publish 


\section{Epilogue}

Mariana Pineda and Blood Wedding, and gave two acts of The Public to print in a literary magazine. Singular episodes such as Martínez Nadal's custody and eventual publication of the manuscript of The Public have contributed, without a doubt, to the powerful Lorca myth whose existence Paul J. Smith first denounced in the late 1980s. While discussions about the transmission of Lorca's poetic works have predictably focused on philological aspects (Life and Miracles of a Lorquian Manuscript was the telling title of Nigel Dennis' famous study on Lorca's Poet in New York), this needs not be the norm in the case of his dramatic corpus. For this reason, I have opted for a contextual approach that makes emphasis on the material conditions of the Spanish theater industry that Lorca sought to conquer and, eventually, reform. In addition, rather than portraying him as a typically avant-gardist artist in search of the "new," I have defined Lorca as both an archaist and an innovator. He was a playwright and theater director who turned to Spanish baroque theater, in particular to Cervantes and Calderón, to borrow a wide range of strategies that he then adapted to challenge the praxis of commercial theater in interwar Spain. Lorca's archaist gestures were not limited to the timeframe represented by these two authors, in any event. He also borrowed motifs and characters from late fifteenth-century and early sixteenth-century drama (the figure of the Foolish Shepherd in The Public, for example) and, as early as 1923, he represented medieval liturgical drama in the puppet spectacle analyzed in Chapter 2. My claim is that in making topical these past Spanish traditions, Lorca was not only thinking in national terms, but also reacting to contemporary issues being discussed by modernist playwrights and directors in other European countries. In order to problematize Lorca's drama beyond national borders, I have proposed comparative readings of his plays while also bringing into discussion theoretical concepts, such as Puchner's idea of antitheatrical drama and Fuchs' theorization of the modernist mysterium, never applied to the Lorquian corpus before.

It is still too early to determine if 2017, the year of expiration of the copyright of Lorca's works, marked the beginning of a new wave of Lorquian scholarship. Even though it is early to tell, no crucial revelations of hidden manuscripts, a la Martínez Nadal, are expected. Recent editorial events seem to suggest that the next debates among Lorquian scholars will be taking place at the macro level of his collected works. This past year of 2019, Javier Huerta Calvo, in collaboration with Sergio Santiago Romero and Javier Domingo Martín, published Teatro completo, a single volume containing all of Lorca's plays. Huerta Calvo, an authority in Spanish Golden Age drama, published a critical edition of Lorca's The Public in 2006 and has written extensively on Lorca's activities with La Barraca. In this new Teatro completo, Huerta Calvo makes use of a vast array of bibliographic resources to contextualize Lorca's theatrical trajectory, adopting a sober approach that even questions commonly accepted facts (see for example his cautious 
words on the premiere of Yerma, in 459-62). Huerta Calvo also stresses Lorca's admiration for Shakespeare and Moliere, on the one hand, and Cervantes, Lope de Vega, Tirso de Molina and Calderón, on the other. Lorca's playwriting, Huerta Calvo argues, represents "a sustained homage" (Introduction Teatro 20, his emphasis) to these authors. These are ideas that coincide with the basic principles of my own study on Lorca. Also last year, Lorquian scholar Andrés Soria Olmedo released the first of the two volumes that will form Lorca's new Collected Works. This first volume contains Lorca's prose-from Impressions and Landscapes (1918) to his conferences and letters-as well as Lorca's poetic production. This volume reflects the textual modifications proposed by Andrew A. Anderson in his 2013 edition of Lorca's Poet in New York, a book of poetry first published in 1940, four years after Lorca's assassination (in the opening pages of this book, I made reference to the troubled textual history of the manuscript of Poet in New York.) The second volume of Soria Olmedo's collection, still to be released, will include all of Lorca's dramatic productions, beginning with his allegorical closet dramas The Primitive Auto Sentimental, Theater of Souls, Of Love. Theater of Animals and Shadows, all written between 1917 and 1920. In 1994, Soria Olmedo became the first editor of these early dramatic writings, which he grouped under the term "youth theater" [Teatro de juventud], after the Spanish Ministry of Culture acquired them in the early 1990s. These closet dramas are not included in Huerta Calvo's collection, which means Soria Olmedo and Huerta Calvo represent two diverging views on Lorca's juvenile attempts at writing a series of dialogues of philosophical orientation.

Outside of Spain, the expiration of the copyright represents an opportunity for the publication of a single volume containing all of Lorca's theatrical works. The most common practice to date has been the publication of English translations in sequences of three or four plays, in some cases according to quite arbitrary criteria. The most comprehensive collection remains the eight-play volume published in 1976, containing the translations that the Lorca estate commissioned to James Graham-Luján and Richard L. O'Connell. This volume does not contain The Public and The Dream of Life, two manuscripts unknown in the mid-1970s, nor Lorca's puppet plays. Regarding the quality of their translations, Gwynne Edwards has noted that Graham-Luján and O'Connell "were hamstrung by the Lorca Estate, which insisted on literal translations," with the result that "they got something that was unspeakable" ("Translators" 251). New English translations became available in the late 1980 s, as international publishers began to respond to the "Lorca boom" (Delgado 7) but, as I just noted, Lorca's dramatic works have never been collected into a single volume released by a major publishing house. In the case of Lorca's first play, The Butterfly's Evil Spell, a new translation is urgent in order to reflect the important changes introduced by Piero 
Menarini in his 1999 reconstructed edition of the text. Also, despite the documentary evidence provided by Andrew A. Anderson and Menarini, Play Without a Title remains as the most commonly used title to refer to The Dream of Life, an error that should be corrected. The only exception, as noted elsewhere in this book, is John London's translation of the play, published in 1996.

In early 2019, Lluís Pasqual directed a new production of The Dream of Life in the Teatro Español of Madrid, the same venue where Lorca, Xirgu and Cherif obtained an astounding success with Yerma in the 1934-35 season. Pasqual's recent production reveals an approach toward a Lorquian text not seen before in Spain. In 2016, the Council of Culture of the government of Madrid commissioned the 'completion' of Lorca's text to Alberto Conejero, who recreated the second act of The Dream of Life after the testimony of Xirgu. In addition, Conejero also "imagined," in his own words, the third and final act of the play that Lorca did not finish. This creative take on The Dream of Life, far from constituting a parodic postmodern rewriting of a classic text, is telling proof of the odd combination of symptoms of admiration and anxiety that Lorca (the man, the author, the myth) still provokes in the Spanish cultural institutions. The desire to 'revive' Lorca became patent in the election of Conejero, a talented playwright with a biography very similar to Lorca (also from Andalusia, he settled in Madrid to pursue an artistic career, as Lorca did). When the Madrid government commissioned him to create the 'continuation' of The Dream of Life, Conejero was 38 years old, the age of Lorca when he was executed by a fascist squad. Conejero himself contributed to this narrative on occasion of the play's premiere. He explained the writing process of this new The Dream of Life as an act of becoming one with the spirit of Lorca, comparing himself to a "sleepwalker" who lived a "hallucination" without the ability to distinguish between "Lorca's imagery and mine." After the play's debut, theater critics resorted to different metaphors to come up with a definition of this experiment with a Lorquian text, most of these metaphors predictably relating to death (a "resuscitation" of Lorca's play, El País; a "continuation of Lorca's unfinished will," $A B C$ ). In other cases, the production was interpreted in terms of a much needed closure ("Lorca, completed at last," La Razón). My engagement with Lorca's theater is obviously different from the press reviewers', who are required to interpret the immediacy of a theater performance. However, I still share with them the feeling of fascination and, sometimes, of confusion, that is consequence of the unique history of creation and transmission of Lorca's works.

\section{Note}

1 Reactions to Harretche's chapter in Huerta Calvo's History were, in general, not favorable. Ricardo Doménech went as far as to define Harretche's work on Lorca as "very regrettable" (190n4). 


\section{Work Cited}

Abel, Lionel. Tragedy and Metatheatre: Essays on Dramatic Form. Ed. Martin Puchner. New York and London: Holmes \& Meier, 2003.

A.C. Review of Blood Wedding, by Federico García Lorca. ABC, 9 March 1933, p. 43.

Ackerman, Alan and Martin Puchner. "Introduction: Modernism and Anti-Theatricality." Against Theatre: Creative Destructions on the Modernist Stage. Eds. Alan Ackerman and Martin Puchner. London: Palgrave Macmillan, 2006. 1-17.

Aguilera Sastre, Juan and Isabel Lizarraga Vizcarra. Federico García Lorca y el teatro clásico: La versión escénica de 'La dama boba'. Rev. ed. Logroño: Universidad de la Rioja, 2008.

_. "Los tres primeros montajes de Amor de Don Perlimplín con Belisa en su jardín, de Lorca. Breve historia de tres experimentos teatrales." Boletín de la Fundación Federico García Lorca 6.12 (1992): 111-26.

Alberti, Rafael. La arboleda perdida. Barcelona: Seix Barral, 1977.

-. "El hombre deshabitado." ABC, 19 February 1931, p. 23.

Allinson, Mark. "Lorca and Pirandello (and not Unamuno): Modernism, Metatheatre." Journal of Iberian and Latin American Studies 3.1 (1997): 5-14.

Anderman, Gunilla. Europe on Stage: Translation and Theatre. London: Oberon Books, 2005.

Anderson, Andrew A. "Introduction." Poeta en Nueva York. By Federico García Lorca. Ed. Andrew A. Anderson. Barcelona: Galaxia Gutenberg, 2013. 7-153.

. "El Público, Asíque pasen cinco años y El sueño de la vida: tres dramas expresionistas de García Lorca." El teatro en España entre la tradición y la vanguardia (1918-1939). Eds. Dru Dougherty and María F. Vilches de Frutos. Madrid: CSIC-Fundación FGL-Tabapress, 1992. 215-26.

—. "The Strategy of García Lorca's Dramatic Composition 1930-1936." Romance Quarterly 33.2 (1986): 211-29.

Anderson, Reed. "Prólogos and Advertencias: Lorca's Beginnings." "Cuando yo me muera...”: Essays in Memory of Federico García Lorca. Ed. C. Brian Morris. Lanham: UP of America, 1988. 209-32.

Andrenio [Eduardo Gómez de Baquero]. Review of The Butterfly's Evil Spell, by Federico García Lorca. La Época, 23 March 1920, p. 1.

_. "Los fantasmas de la historia." Review of Mariana Pineda, by Federico García Lorca. La Vanguardia, 18 October 1927, p. 9. 
Anonymous. "Homenaje a García Lorca." La Gaceta Literaria, issue 21, 1 November 1927, p. 5.

- Review of The Butterfly's Evil Spell, by Federico García Lorca. El Debate, 23 March 1920, p. 2.

- Review of The Butterfly's Evil Spell, by Federico García Lorca. Hoy, 23 March 1920, p. 3.

- Review of The Butterfly's Evil Spell, by Federico García Lorca. El Liberal, 23 March 1920, p. 3.

- "Una encuesta a la juventud española." La Gaceta Literaria, issue 21, 1 November 1927 , p. 5.

- "Una encuesta a la juventud española." La Gaceta Literaria, issue 22, 15 November 1927, p. 1.

Aszyk, Ursula. "El teatro inconcluso de Federico García Lorca. Hacia una valoración nueva de la obra dramática lorquiana." Actas Universitatis Wratislaviensis 1370 (1992): 261-78.

Ayala, Francisco. "Basterra, el granviario." La Gaceta Literaria, issue 21, 1 November 1927, p. 1.

-. "Mariana Pineda." La Gaceta Literaria, issue 20, 15 October 1927, p. 5.

Aznar Navarro, Francisco. Review of The Butterfly's Evil Spell, by Federico García Lorca. La Correspondencia de España, 23 March 1920, p. 4.

Azorín [José Martínez Ruiz]. "Dos autos sacramentales.” ABC, 15 May 1926, pp. 3-4.

Badenes, José I. “'This is My Body which Will Be Given Up for You': Federico García Lorca's Amor de Don Perlimplín and the Auto Sacramental Tradition." Hispania 92.4 (December 2009): 688-95.

- "Staging the Senex: Aging Masculinities in the Theater of Miguel de Cervantes and Federico García Lorca.” Romance Notes 54.3 (2014): 335-46.

Balcells, Josep María. "Cartas de Margarita Xirgu sobre Lorca y Alberti." Cuadernos hispanoamericanos 433-4 (July-August 1986): 195-8.

Beltrán, Gina. "Spatial Dynamics in Lorca's La casa de Bernarda Alba: From the Dramatic Text to the Performance.” Transverse 8 (Spring 2008): 36-43.

Benabu, Isaac. "Problemática de la lectura teatral del personaje: el caso de Bernarda Alba." Theatralia 11 (2009): 127-41.

Benjamin, Walter. "The Author as Producer." Understanding Brecht. Trans. Anna Bostock. London and New York: Verso, 1998. 85-103.

- The Origin of German Tragic Drama. Trans. John Osborne. London: NLB, 1977.

- "What is Epic Theater?" Illuminations. Trans. Harry Zohn. Ed. Hannah Arendt. New York: Schocken Books, 1969. 147-54.

Bergamín, José. “El canto y la cal en la poesía de Rafael Alberti.” La Gaceta Literaria, issue 6, 15 March 1927, p. 2.

Blum, Bilha. "The Struggle for Supremacy: Life and Death in Lorca's Bodas de sangre." Theatralia 11 (2009): 77-88.

Brecht, Bertolt. "The Epic Theatre and Its Difficulties.” Brecht on Theatre. Ed. and trans. John Willett. New York: Hill and Wang, 1992. 22-4.

Brotherton, John. The 'Pastor-Bobo' in the Spanish Theatre. Before the Time of Lope de Vega. London: Tamesis, 1975.

- "Promiscuous Dolls and Faithful Wives: Some Aspects of Puppetry in the Plays of García Lorca.” Romance Languages Annual 7 (1995): 385-91. 
Brušák, Karel. “Imaginary Action Space in Drama.” Drama und Theater: Theorie, Methode, Geschichte. Eds. Herta Schmid and Hedwig Král. Munich: Otto Sagner, 1991. 144-62.

Byrd, Suzanne W. García Lorca: La Barraca and the Spanish National Theater. New York: Abra, 1975.

. "The Puppet Theater as Genesis of Lorcan Drama." García Lorca Review 6 (1978): 139-49.

Calderón de la Barca, Pedro. Autos sacramentales. 2 vols. Ed. Ángel Valbuena Prat. Madrid: Ediciones de La Lectura, 1926-27.

- The Great Theater of the World. In Calderón de la Barca: Four Great Plays of the Golden Age. Trans. Rick Davis. Hanover: Smith \& Kraus, 2008. 231-66.

Cannon, Calvin. "Yerma as Tragedy." Symposium 16.2 (Summer 1962): 85-93.

Castillo, David. R. "Horror (Vacui): The Baroque Condition.” In Hispanic Baroques: Reading Cultures in Context. Eds. Nicholas Spadaccini and Luis Martín-Estudillo. Nashville: Vanderbilt UP, 2005. 87-105.

Cervantes, Miguel de. Eight Interludes. Trans. Dawn L. Smith. London and Vermont: J.M. Dent and C.E. Tuttle, 1996.

- The Man who Pretended to be from Biscay. In Eight Interludes. Trans. Dawn L. Smith. London and Vermont: J.M. Dent and C.E. Tuttle, 1996. 73-91.

- The Marvelous Puppet Show. In Eight Interludes. Trans. Dawn L. Smith. London and Vermont: J.M. Dent and C.E. Tuttle, 1996. 93-109.

Conejero, Alberto. "El sueño de la vida.” Teatro Español, 17 January 2019, n.p.

Craig, Edward Gordon. On the Art of the Theatre. London: Heinemann, 1968.

Cueva, José de la. "En el Beatriz: Bodas de sangre." Informaciones, 8 March 1933, p. 14.

Deak, František. Symbolist Theater: The Formation of an Avant-Garde. Baltimore and London: Johns Hopkins UP, 1993.

Delgado, Maria M. Federico García Lorca. London and New York: Routledge, 2008.

Dennis, Nigel. Vida y milagros de un manuscrito de Lorca: en pos de Poeta en Nueva York. Santander: Sociedad Menéndez Pelayo, 2000.

Derrida, Jacques. "Structure, Sign, and Play in the Discourse of the Human Sciences." Writing and Difference. Trans. Alan Bass. Chicago: U of Chicago P. 278-93.

Diago, Neil. "El estreno de La casa de Bernarda Alba en la prensa argentina de la época.” Anales de la literatura española contemporánea 37.2 (2012): 147-69.

Díez-Canedo, Enrique. "Arte dramático en España. Teatro de mujeres.” La Nación, 6 October 1935.

—. "Yerma, el poema trágico de Federico García Lorca, obtuvo un extraordinario éxito en el Español.” La Voz, 31 December 1934, p. 3.

Doménech, Ricardo. García Lorca y la tragedia española. Madrid: Fundamentos, 2008.

Doncel, Diego. "El lugar del teatro en tiempos convulsos." Review of The Dream of Life, by Federico García Lorca and Alberto Conejero. ABC, 21 January 2019.

Dougherty, Dru. “'Es un asco el teatro': Eduardo Marquina y el estreno de Mariana Pineda en Barcelona (1927)." Federico García Lorca i Catalunya. Eds. Antonio Monegal and José M. Mico. Barcelona: Institut Universitari de Cultura-Universitat Pompeu Fabra-Diputació de Barcelona, 2000. 17-31. 
Dougherty, Dru and Andrew A. Anderson. "Continuity and Innovation in Spanish Theatre, 1900-1936." A History of Theatre in Spain. Eds. Maria Delgado and David T. Gies. Cambridge: Cambridge UP, 2015. 282-309.

Dougherty, Dru and María F. Vilches de Frutos. La escena madrileña entre 1918 y 1926: análisis y documentación. Madrid: Fundamentos, 1990.

—. La escena madrileña entre 1926 y 1931: un lustro de transición. Madrid: Fundamentos, 1997.

Drábek, Pavel. "Launching a Structuralist Assembly: Convening the Scattered Structures." Theatralia 15.2 (2012): 13-23.

Edwards, Gwynne. "Bodas de sangre in Performance." Anales de la Literatura Española Contemporánea 22.3 (1997): 469-91.

_. "Translators' Panel Discussion: John Clifford, John Edmunds, Gwynne Edwards, David Johnston, Nicholas Round, Colin Teevan, Merryn Williams." Fire, Blood and the Alphabet: One Hundred Years of Lorca. Eds. Sebastian Doggart and Michael Thompson. Durham: Durham UP, 1999. 237-59.

- "The Way Things Are: Towards a Definition of Lorcan Tragedy." Anales de la literatura española contemporánea 21.3 (1996): 271-90.

Egginton, William. "The Baroque as a Problem of Thought." PMLA 124.1 (January 2009): 143-9.

- "An Epistemology of the Stage: Theatricality and Subjectivity in Early Modern Spain.” New Literary History 27.3 (Summer 1996): 391-413.

- How the World Became a Stage. Albany: State U of New York P, 2003.

- The Theater of Truth: The Ideology of (Neo)Baroque Aesthetics. Stanford: Stanford UP, 2010.

Estévez Ortega, Enrique. "Un retorno a lo clásico. Calderón, dentro y fuera de España.” La Esfera, September 1927, p. 38.

Fernández Almagro, Melchor. "El centenario de Mariana Pineda.” FGL: Boletín de la Fundación Federico García Lorca 41-2 (2007): 83-6.

-. "Primer estreno de Federico García Lorca." ABC, 13 June 1952, pp. 15, 19.

Fernández Cifuentes, Luis. García Lorca en el teatro: la norma y la diferencia. Zaragoza: Prensas Universitarias de Zaragoza, 1986.

-. "¿Qué es aquello que relumbra? (Una última cuestión).” Federico García Lorca, clásico moderno (1898-1998). Eds. Andrés Soria Olmedo et al. Granada: Diputación de Granada, 2000. 220-37.

Fuchs, Elinor. The Death of Character: Perspectives on Theater after Modernism. Bloomington: Indiana UP, 1996.

Fuentes, Rafael. "1941.Bodas de sangre, de Federico García Lorca. La simplificación de una gran tragedia." El Imparcial, 12 January 2019, n.p. Online.

Gainor, J. Ellen, Stanton B. Garner and Martin Puchner, eds. The Norton Anthology of Drama. Vol. II: The Nineteenth Century to the Present. New York: W. W. Norton, 2009.

Gale, Maggie B. "Introductory essay. The Historical Avant-Garde: Performance and Innovation." The Routledge Drama Anthology and Sourcebook: From Modernism to Contemporary Performance. London and New York: Routledge, 2010. 170-87.

Gale, Maggie B. and John F. Deeney, eds. The Routledge Drama Anthology and Sourcebook: From Modernism to Contemporary Performance. London and New York: Routledge, 2010. 
Gallego Morell, Antonio. "Resurrección de los autos sacramentales. (Madrid, junio 1765 - Granada, junio 1927).” ABC, 20 November 1960, p. 43.

García Lorca, Federico. The Billy-Club Puppets. In Five Plays: Comedies and Tragicomedies. Trans. James Graham-Lujan and Richard L. O’Connell. New York: New Directions, 1963.

. Blood Wedding. Trans. Jo Clifford. London: Nick Hern Books, 2008.

. The Dream of Life. In The Unknown Lorca: Dialogues, Dramatic Proj-

ects, Unfinished Plays \& A Filmscript. Ed. and trans. John London. London:

Atlas Press, 1996. 93-112.

- Five Plays: Comedies and Tragicomedies. Trans. James Graham-Lujan and Richard L. O'Connell. New York: New Directions, 1963.

- In the Frame of Don Cristóbal: A Farce. In Four Puppet Plays, Play Without a Title, the Divan Poems. Trans. Edwin Honig. Riverdale-on-Hudson: The Sheep Meadow P, 1990. 17-31.

- The House of Bernarda Alba. Trans. Jo Clifford. London: Nick Hern Books, 2012.

- The Love of Don Perlimplin and Belisa in the Garden. In Five Plays: Comedies and Tragicomedies. Trans. James Graham-Lujan and Richard L. O’Connell. New York: New Directions, 1963. 105-30.

- Obras completas. Prosa (Vol. 3). Ed. Miguel García-Posada. Barcelona: Galaxia Gutenberg-Círculo de Lectores, 1996.

- Palabra de Lorca: entrevistas y declaraciones completas. Ed. Rafael Inglada. Barcelona: Malpaso, 2018.

- The Public and Play Without a Title: Two Posthumous Plays. Trans. Carlos Bauer. New York: New Directions, 1983.

—. El público. Ed. Javier Huerta Calvo. Madrid: Espasa, 2006.

—. El público. Ed. María Clementa Millán. Madrid: Cátedra, 1987.

- El público (de un drama en cinco actos). Ed. Luis Trigueros-Ramos y López. Bloomington: Palibrio, 2013.

- El público y Comedia sin título: dos obras póstumas. Eds. Rafael Martínez Nadal and Marie Laffranque. Barcelona: Seix Barral, 1978. 2000 .

—. Romancero gitano. Poeta en Nueva York. El público. Ed. Derek Harris. Madrid: Taurus, 1993.

- The Shoemaker's Prodigious Wife. In Five Plays: Comedies and Tragicomedies. Trans. James Graham-Lujan and Richard L. O'Connell. New York: New Directions, 1963. 57-104.

—. Teatro inédito de juventud. Ed. Andrés Soria Olmedo. Madrid: Cátedra, 1994.

- Yerma. Trans. Ian Macpherson and Jacqueline Minett. Warminster: Aris \& Phillips, 1987.

García Lorca, Francisco. Federico y su mundo. Ed. Mario Hernández. Madrid: Alianza, 1981.

García Maestro, Jesús. "Lorca y la tragedia en el teatro del siglo XX.” Theatralia 11 (2009): 13-42.

García-Posada, Miguel. "Introduction." Obras completas. Teatro (Vol. 2). By Federico García Lorca. Ed. Miguel García-Posada. Barcelona: Galaxia Gutenberg-Círculo de Lectores, 1997. 9-28. 
Gaylord, Mary M. "Pulling Strings with Master Peter's Puppets: Fiction and History in Don Quixote." Bulletin of the Cervantes Society of America 18.2 (Fall 1998): 117-47.

Gerling, David R. "Amor de Don Perlimplín con Belisa en su jardín. Aleluya erótica en cuatro cuadros y un prólogo: Síntesis de las farsas de Federico García Lorca.” Discurso literario 10.1 (1992): 151-65.

Gibson, Ian. Vida, pasión y muerte de Federico García Lorca. Rev. ed. Barcelona: Debolsillo, 2016.

Gil Fombellida, María del Carmen. Rivas Cherif, Margarita Xirgu y el teatro de la II República. Madrid: Fundamentos, 2003.

Gobert, R. Darren. "Cognitive Catharsis in The Caucasian Chalk Circle." Modern Drama 49.1 (Spring 2006): 12-40.

Gómez Torres, Ana M. "La destrucción o el teatro: El público de García Lorca." Le théâtre de l'impossible: voir et lire Federico García Lorca. Ed. Jean-Marie Lavaud. Dijon: Université de Bourgogne, 1999. 17-38

- Experimentación y teoría en el teatro de Federico García Lorca. Málaga: Arguval, 1995.

- "El teatro metafísico de Federico García Lorca." La verdad de las máscaras. Teatro y vanguardia en Federico García Lorca. Eds. Antonio Chicharro and Antonio Sánchez Trigueros. Granada: Alhulia, 2005. 81-115.

González Ramírez, David. "La escenificación de El gran teatro del mundo (Granada, 1927). Consideraciones sobre 'la vuelta a Calderón'.” Boletín Millares Carlo 28 (2009): 305-34.

González del Valle, Luis. "Justicia poética en Bodas de sangre." Romance Notes 14.2 (Winter 1972): 236-41.

Greenfield, Sumner M. "Lorca's Theatre: A Synthetic Reexamination.” Journal of Spanish Studies: Twentieth Century 5.1 (Spring 1977): 31-46.

Gross, Kenneth. Puppet: An Essay on Uncanny Life. Chicago: Chicago UP, 2011.

Gruber, William. Offstage Space, Narrative, and the Theatre of the Imagination. New York: Palgrave Macmillan, 2010.

Halliburton, Charles Lloyd. "García Lorca, the Tragedian: An Aristotelian Analysis of Bodas de Sangre." Revista de Estudios Hispánicos 2.1 (April 1968): 35-40.

Harretche, María E. Federico García Lorca: análisis de una revolución teatral. Madrid: Gredos, 2000.

—. "García Lorca." Historia del teatro español. Vol. 2 (Del siglo XVIII a la época actual). Ed. Javier Huerta Calvo. Madrid: Gredos, 2003. 2455-502.

Havard, Robert G. "Introduction.” Mariana Pineda. By Federico García Lorca. Ed. and trans. Robert G. Havard. Warminster: Aris \& Phillips, 1987. 1-24.

Hernández, Mario. "Cronología y estreno de Yerma, poema trágico, de García Lorca." Revista de archivos, bibliotecas y museos 82.2 (April-June 1979): 289-315.

—. "Introduction." La casa de Bernarda Alba. By Federico García Lorca. Ed. Mario Hernández. 3rd ed. Madrid: Alianza, 2012. 9-50.

. "Introduction." El retablillo de Don Cristóbal y la señá Rosita: aleluya popular basada en el viejo y desvergonzado guiñol andaluz (versión inédita de Buenos Aires, 1934). By Federico García Lorca. Ed. Mario Hernández. Granada: Diputación Provincial de Granada-Patronato Federico García Lorca, 1992. 7-29. 
"Retablo de las maravillas: Falla, Lorca y Lanz en una fiesta granadina de títeres." Teatro de títeres y dibujos (con decorados y muñecos de Hermenegildo Lanz). By Federico García Lorca. Ed. Mario Hernández. Santander: UIMP-Fundación FGL, 1992. 33-52.

Herrera Cepero, Daniel. "Poeta en Nueva York, libro de artista: desparatextualización de los dibujos neoyorquinos de García Lorca." Cincinnati Romance Review 42 (Spring 2017): 108-27.

Herrero, Julián. "Lorca, por fin acabado." La Razón, 11 January 2019.

Honzl, Jindřich. "Dynamics of Sign in the Theater." Semiotics of Art: Prague School Contributions. Eds. Ladislav Matejka and Irwin R. Titunik. Cambridge: MIT Press, 1976. 75-94.

Huerta Calvo, Javier. La Barraca. Teatro y universidad: ayer y hoy de una utopía. Madrid: Acción Cultural Española, 2011.

- "Cervantes y Lorca: La Barraca." Don Galán. Revista de Investigación Teatral 5 (2014): 1-20.

—. "Introduction." El público. By Federico García Lorca. Ed. Javier Huerta Calvo. Madrid: Espasa, 2006. 9-86.

—. "Introduction." Teatro completo. By Federico García Lorca. Ed. Javier Huerta Calvo et al. Madrid: Verbum, 2019. 9-66.

J.A. Review of The Butterfly's Evil Spell, by Federico García Lorca. El Sol, 23 March 1920, p. 11.

Jerez-Farrán, Carlos. "El sadomasoquismo homoerótico como expresión de homofobia internalizada en el cuadro 2 de El público de García Lorca.” Modern Philology 93.4 (May 1996): 468-97.

- "Towards a Foucauldian Exegesis of Act V of García Lorca's El público.” Modern Language Review 95.3 (July 2000): 728-43.

Jiménez León, Marcelino. Enrique Díez-Canedo, crítico literario (Vol. 1). Doctoral dissertation. U of Barcelona, 2001.

Johnson, Roberta. "Federico García Lorca's Theater and Spanish Feminism." Anales de la literatura española contemporánea 33.2 (2008): 251-81.

Kasten, Carey. The Cultural Politics of Twentieth-Century Spanish Theater: Representing the Auto Sacramental. Lewisburg: Bucknell UP, 2012.

Klein, Dennis A. 'Blood Wedding, 'Yerma,' and 'The House of Bernarda Alba': García Lorca's Tragic Trilogy. Boston: Twayne Publishers, 1991.

Laffranque, Marie. Introduction. El público y Comedia sin título: dos obras póstumas. Eds. Rafael Martínez Nadal and Marie Laffranque. Barcelona: Seix Barral, 1978. 273-316.

Larrea Rubio, Pedro. Federico García Lorca en Buenos Aires. Sevilla: Renacimiento, 2015.

Loynaz, Dulce M. "Más sobre Lorca.” ABC, 16 September 1989, p. 30. p. 42 .

Lluch Garín, Felipe. “Bodas de sangre.” Sparta, 4 March 1933.

Machado, Manuel. Review of The Butterfly's Evil Spell, by Federico García Lorca. La Libertad, 23 March 1920, p. 2.

Marquina, Eduardo. "La batalla de Alberti." La Gaceta Literaria, issue 101, 15 March 1931, p. 6.

Martínez Nadal, Rafael. "Introduction." El público y Comedia sin título: dos obras póstumas. Eds. Rafael Martínez Nadal and Marie Laffranque. Barcelona: Seix Barral, 1978. 11-29. 
'El Público': amor y muerte en la obra de Federico García Lorca. 3rd ed. Madrid: Hiperión, 1988.

Martínez Lacalle, Guadalupe. "Yerma: 'Una tragedia pura y simplemente'.” Neophilologus 72 (1988): 227-37.

Materna, Linda. "Los códigos genéricos sexuales y la presentación de la mujer en el teatro de García Lorca." Estelas, laberintos, nuevas sendas: Unamuno. Valle-Inclán. García Lorca. La guerra civil. Ed. Ángel G. Loureiro. Barcelona: Anthropos, 1988. 263-77.

Mayhew, Jonathan. Lorca's Legacy: Essays on Interpretation. New York: Routledge, 2018.

McKendrick, Melveena. Identities in Crisis: Essays on Honour, Gender and Women in the 'Comedia'. Kassel: Reichenberger, 2002.

Menarini, Piero. "Federico y los títeres: cronología y dos documentos.” Boletín de la Fundación Federico García Lorca 3.5 (June 1989): 103-28.

_. "Gli anni dei burattini." L'imposible/posible di Federico García Lorca. Ed. Laura Dolfi. Naples: Edizioni Scientifiche Italiane, 1989. 139-54.

_. "Introduction." El maleficio de la mariposa. By Federico García Lorca. Ed. Piero Menarini. Madrid: Cátedra, 1999. 9-73.

. "Mariana Pineda en dos dramas románticos." Actas del IX Congreso de la Asociación Internacional de Hispanistas 18-23 agosto 1986. Vol. II. Berlín-Frankfurt am Main: Vervuert, 1989. 65-73.

—. "El público y Comedia sin título: Dos enmiendas posibles y un reportaje olvidado." Salina 9 (1995): 67-74.

Ménendez Pelayo, Marcelino. Calderón y su teatro. Buenos Aires: Emecé, 1946. Miquis, Alejandro. "Review of The Butterfly's Evil Spell, by Federico García Lorca." El Universal, 24 March 1920, p. 3.

Monegal, Antonio. "Un-Masking the Maskuline: Transvestism and Tragedy in García Lorca's El Público.” Modern Language Notes 109.2 (1994): 204-16.

Mora Guarnido, José. Federico García Lorca y su mundo. Granada: Fundación Caja de Granada, 1988.

—. "El teatro cachiporra andaluz." La Voz, 12 January 1923, p. 2.

—. "El teatro cachiporra de Andalucía." La Voz, 19 January 1923, p. 4.

Morales, María-Luz. "Un sensacional estreno: Yerma, poema trágico, en tres actos, de Federico García Lorca." La Vanguardia, 19 September 1935, p. 10.

Moser, Walter. "The Concept of Baroque." Revista Canadiense de Estudios Hispánicos 33.1 (Fall 2008): 11-37.

Mukařovský, Jan. "The Concept of the Whole in the Theory of Art." Structure, Sign, and Function. Ed. and trans. John Burbank and Peter Steiner. New Haven: Yale UP, 1978. 70-81.

- "The Place of the Aesthetic Function among the Other Functions." Structure, Sign, and Function. Ed. and trans. John Burbank and Peter Steiner. New Haven: Yale UP, 1978. 31-48.

- "Intentionality and Unintentionality in Art." Structure, Sign, and Function. Ed. and trans. John Burbank and Peter Steiner. New Haven: Yale UP, 1978. 89-128.

- "On Structuralism." Structure, Sign, and Function. Ed. and trans. John Burbank and Peter Steiner. New Haven: Yale UP, 1978. 3-16.

- Structure, Sign, and Function. Ed. and trans. John Burbank and Peter Steiner. New Haven: Yale UP, 1978. 
Muñiz, Alfredo. "Yerma, el poema trágico de Federico García Lorca, admirablemente interpretado por Margarita Xirgu y su compañía, alcanzó en el Español un triunfo clamoroso." Heraldo de Madrid, 31 December 1934, p. 4.

Muñoz-Alonso López, Agustín. "Introduction.” Teatro español de vanguardia. Ed. Agustín Muñoz-Alonso López. Madrid: Castalia, 2003. 9-72.

"El modelo calderoniano en el contexto de la renovación teatral en el primer tercio del siglo XX.” Teatro: Revista de Estudios Culturales 20.4 (2004): 69-86.

Nelson, Bradley J. "From Hieroglyphic Presence to Representational Sign: An Other Point of View in the Auto Sacramental." In Hispanic Baroques: Reading Cultures in Context. Eds. Nicholas Spadaccini and Luis Martín-Estudillo. Nashville: Vanderbilt UP, 2005. 107-36.

Nieva de la Paz, Pilar. "Identidad femenina, identidad y moral social: Yerma (1935), de Federico García Lorca.” Anales de la literatura española contemporánea 33.2 (2008): 373-94.

—. "La polémica teatral en Sparta, revista de espectáculos (1932-33)." Siglo XX/20th Century 7.1-2 (1989-90): 12-9.

Ordóñez, Marcos. "Una fiera belleza." Review of The Dream of Life, by Federico García Lorca and Alberto Conejero. El País, 25 January 2019.

Ortega y Gasset, José. La deshumanización del arte. Ideas sobre la novela. 2nd ed. Madrid: Revista de Occidente, 1928.

Paco de Moya, Mariano de. "El drama rural en España." Anales de la Universidad de Murcia. Filosofía y Letras 30.1-2 (1971-72): 141-70.

Palacios, Leopoldo-Eulogio. "Anotaciones a El hombre deshabitado." La Gaceta Literaria, issue 101, 15 March 1931, p. 5.

Parker, Alexander A. The Allegorical Drama of Calderón. Oxford: The Dolphin Book, 1968.

Paulino Ayuso, José. “El teatro de la subjetividad y la influencia del psicoanálisis.” Boletín de la Fundación Federico García Lorca 19-20 (1996): 69-85.

Peral Vega, Emilio. Introduction. Comedia sin título (seguida de 'El sueño de la vida’ de Alberto Conejero). By Federico García Lorca. Ed. Emilio Peral Vega. Madrid: Cátedra, 2018. 10-71.

Percas de Ponseti, Helena. "Authorial Strings: A Recurrent Metaphor in Don Quijote." Cervantes: Bulletin of the Cervantes Society of America 1.1-2 (1981): 51-62.

Pirandello, Luigi. Six Characters in Search of an Author. Trans. Edward Storer. Mineola: Dover Publications, 1998.

Pomo, Roberto D. “A Director Discusses Blood Wedding with His Cast.” The Longman Anthology of Modern and Contemporary Drama: A Modern Perspective. Ed. Michael Greenwald et al. New York: Pearson Longman, 2004. 275-7.

Puchner, Martin. Stage Fright. Modernism, Anti-Theatricality, and Drama. Baltimore and London: The Johns Hopkins UP, 2002.

Quinn, Michael L. The Semiotic Stage. New York: Peter Lang, 1995.

Regalado, Antonio. Calderón: Los orígenes de la modernidad en la España del Siglo de Oro. Vol. 1. Barcelona: Destino, 1995.

Reichenberger, Arnold G. "The Uniqueness of the Comedia." Hispanic Review 38.2 (April 1970): 163-73.

Rivas Cherif, Cipriano. Cómo hacer teatro. Ed. Enrique de Rivas. Pretextos: Valencia, 1991. 
Rodrigo, Antonina. García Lorca, el amigo de Cataluña. Barcelona: Edhasa, 1984.

Rodríguez Cuadros, Evangelina. La técnica del actor español en el Barroco. Hipótesis y documentos. Madrid: Castalia, 1998.

Rodriguez-Solás, David. Teatros nacionales republicanos: la Segunda República y el teatro clásico español. Madrid-Frankfurt: Iberoamericana-Vervuert, 2014.

Rubia Barcia, José. "Ropaje y desnudez de El Público." Cuadernos Hispanoamericanos 433-4 (July-August 1986): 385-98.

Sáenz de la Calzada, Luis. 'La Barraca'. Teatro Universitario. Madrid: Revista de Occidente, 1976.

Salado, José Luis. "En el ensayo general de Yerma, la comedia de García Lorca, se congregaron entre otros ilustres rostros rasurados, las tres barbas más insignes de España: las de Unamuno, Benavente y Valle-Inclán.” La Voz, 29 December 1934, p. 3.

—. "¿Por qué se parecen todos los dramas rurales?.” Heraldo de Madrid, 16 September 1929 , p. 6.

Salaün, Serge. Introduction. Teatro de ensueño. La intrusa (de Maurice Maeterlinck). By Gregorio Martínez Sierra. Ed. Serge Salaün. Madrid: Biblioteca Nueva, 1999. 9-118.

Sarduy, Severo. "The Baroque and the Neobaroque." Baroque New Worlds: Representation, Transculturation, Counterconquest. Eds. Lois Parkinson Zamora and Monica Kaup. Durham: Duke UP. 270-91.

Sidnell, Michael. "Aesthetic Prejudice in Modern Drama." Modern Drama 44.1 (2001): 16-30.

Smith, Paul Julian. The Body Hispanic: Gender and Sexuality in Spanish and Spanish American Literature. Oxford: Clarendon, 1989.

- "Lorca's Legacy. Writing in the Institution." Fire, Blood and the Alphabet: One Hundred Years of Lorca. Durham: Durham Modern Language Series, 1999. 31-42.

- The Theatre of García Lorca: Text, Performance, Psychoanalysis. Cambridge: Cambridge UP, 1998.

Soria Olmedo, Andrés. Fábula de fuentes. Tradición y vida literaria en Federico García Lorca. Madrid: Publicaciones de la Residencia de Estudiantes, 2004.

Soufas, C. Christopher. Audience and Authority in the Modernist Theater of Federico García Lorca. Tuscaloosa: Alabama UP, 1996.

Spadaccini, Nicholas and Luis Martín-Estudillo, eds. Hispanic Baroques: Reading Cultures in Context. Nashville: Vanderbilt UP, 2005.

Spadaccini, Nicholas and Jenaro Talens. Through the Shattering Glass: Cervantes and the Self-Made World. Minneapolis: Minnesota UP, 1993.

Stainton, Leslie. Lorca: A Dream of Life. New York: Farrar, Straus, Giroux, 1999.

Stimson, Frederick S. “Lo invisible: Azorín's Debt to Maeterlinck.” Hispanic Review 26.1 (January 1958): 64-70.

Szondi, Peter. Theory of the Modern Drama. Ed. and trans. Michael Hays. Minneapolis: U of Minnesota P, 1987.

Thacker, Jonathan. A Companion to Golden Age Theatre. Woodbridge and Rochester: Boydell \& Brewer and Tamesis, 2007. 
Torre, Guillermo de. "Federico García Lorca y sus orígenes dramáticos." Clavileño 5 (March-April 1954): 14-8.

Torres Nebrera, Gregorio. "Del teatro inconcluso de García Lorca: apostillas a Los sueños de mi prima Aurelia." Anuario de Estudios Filológicos 22 (1999): 425-45.

Tynianov, Yuri. Arkhaisty i novatory. Leningrad: Priboi, 1929.

Valbuena Prat, Ángel. "El gran teatro del mundo." La Gaceta Literaria, issue 101, 15 March 1931, pp. 5-6.

Veltruský, Jiří. "People and Things in the Theatre." Theatre Theory Reader: Prague School Writings. Eds. David Drozd, Tomáš Kačer and Don Sparling. Prague: Karolinum, 2016. 147-56.

- "The Prague School Theory of Theater." Poetics Today 2.3 (1981): 225-35.

—. "Semiotics and Avant-Garde Theatre." Theatre Survey 36.1 (1995): 87-95.

—. "Structure in Folk Theater: Notes regarding Bogatyrev's Book on Czech and Slovak Folk Theater." Poetics Today 8.1 (1987): 141-61.

Vidal, Fabián. “iQué lástima!.” Review of Mariana Pineda, by Federico García Lorca. La Vanguardia, 22 October 1927, p. 5.

Vilches de Frutos, María Teresa. Introduction. La casa de Bernarda Alba. By Federico García Lorca. Ed. María Teresa Vilches de Frutos. Madrid: Cátedra, 2015. 11-133.

Vitale, Rosanna. El metateatro en la obra de Federico García Lorca. Madrid: Pliegos, 1991.

Wardropper, Bruce W. “Menéndez Pelayo on Calderón.” Criticism 7.4 (Fall 1965): 363-72.

Wright, Sarah. “Theatre.” A Companion to Federico García Lorca. Ed. Federico Bonaddio. Woodbridge: Tamesis, 2007. 39-62.

- The Trickster-Function in the Theatre of Garcia Lorca. Woodbridge and Rochester: Tamesis, 2000.

Zich, Otakar. Estetika dramatického umèní. Prague: Panorama, 1986. 

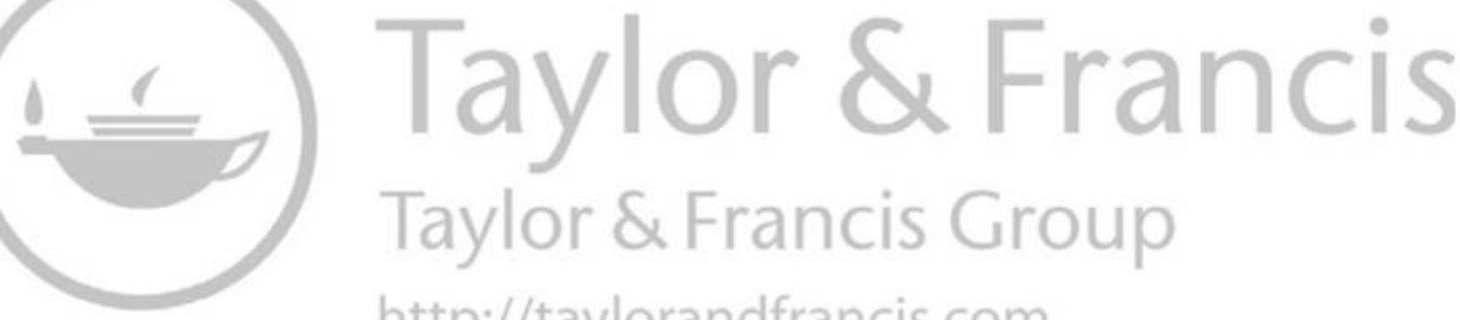
http://taylorandfrancis.com 


\section{Index}

Note: Page numbers followed by " $n$ " denote endnotes.

$A B C$ newspaper $14,31,40,69$, 75,129

Abel, Lionel 51

Aesthetics of Dramatic Art (Zich) 43n8

agrarian trilogy 3-4, 10, 122, 130, 137

Alberti, Rafael 17, 90, 92, 99, 119; artistic legacy 119; The Lost Grove 93; The Uninhabited Man 102, 118, 122

Anderson, Andrew A. 2, 18, 111, 112, $116,139,140$

Anderson, Reed 28

Andrenio 29, 32, 39

Àngel Guimerà (drama) 20, 116

Anniversary of the Death of Doña Mariana Pineda (Nieto) 38

Appia, Adolphe 91

Artigas, Santiago 6

artistic intentionality 25-6

As Five Years Pass (Lorca) 116

Asturian Revolution of October 1934 94, 95, 99

"authentic Hispanism" 115

"The Author as Producer"

(Benjamin) 22n3

"autocritica" genre 38, 40, 41, 92

auto sacramental genre 5, 17-19, 67,

$68,74,76,77,81,87 \mathrm{n} 7,89,92$,

93, 102

autotelic art, theory of 24

Ayala, Francisco 42

Azorín (José Martínez Ruiz) 75

Badenes, Juan Ignacio 66n7

The Baden Play for Learning

(Brecht) 104

de Basterra, Ramón 42
Benavente, Jacinto 20, 31, 93, 114, 118

Benjamin, Walter: "The Author as Producer" 22n3; The Origin of German Tragic Drama 87n8; "What is Epic Theatre?" 105

Bergamín, José 1, 2, 92, 102

Billy-Club Puppets see cachiporra puppets

The Billy-Club Puppets (Lorca) 7-8, $15,45,46,49,57,58$

Blood Wedding (Lorca) 8, 19, 20-1, 22n4, 30, 67, 95, 111-16, 111-23, 125-7, 129-33, 138

Bogatyrev, Petr 47

Bouchor, Maurice 65n1

Brecht, Bertolt 27, 105, 110, 124; The Baden Play for Learning 104

Brotherton, John 47, 71, 72

Buenos Aires 46

Buñuel, Luis 12, 40

The Butterfly's Evil Spell (Lorca) 4-5, 7, 12-15, 23, 24, 38, 45, 55, 58, 82, 127,139 ; inarticulate nature of 27 ; lyricism and plot progression in 29; vs. Mariana Pineda 40-1; materially remainings of 24-5; negative experience of 45 ; production of 31 , 33; prologue scene of $27-8$

cachiporra puppets 45, 49

Calderón de la Barca, Pedro 5, 67, 76, 111, 127, 131, 139; autos 19, 90, 91; The Girl of Gomez Arias 91; The Great Theater of the World 17, 73, 74, 75, 76, 80, 89, 91, 92, 93; The Mayor of Zalamea 74; The Phantom Lady 74

Calvo Sotelo, José 68 


\section{Index}

Cervantes, Miguel de 5, 45, 47, 50-7, 60, 66n4, 66n5, 125; The Jealous Extremaduran 125; The Man who Pretended to be from Biscay 45, 52-4; The Marvelous Puppet Show 45, 52-3, 56; Master Pedro's traveling show (Don Quixote) 55-7; The Two Talkers 49, 52, 96

Citizen Kane (Welles) 69

Clementa Millán, María 68, 69, 70

Club Anfistora 8

Club Teatral de Cultura 111

Cocteau, Jean 79

Craig, Edward Gordon 48, 50, 91

cristobicas puppets 46, 49, 56

cristobitas/cristobicas 45

Dalí, Salvador 6, 12, 40, 41, 92

D'Amico, Silvio 25

The Death of Character (Fuchs) 19

The Dehumanization of Art

(Ortega y Gasset) 34

Delgado, Maria M. 4, 9, 107

Derrida, Jacques 26

The Destruction of Sodom (Lorca) 113

Díaz, Josefina 20, 113, 117, 118

Díez-Canedo, Enrique 74, 118, 128

Díez Fernández, José: The New Romanticism 93

Dona Rosita the Spinster (Lorca) 116

"drama," definition 124

The Dream of Life (Lorca) 18-19, 24, 28, 32, 89, 90, 96, 97, 98, 99, 100, 103-4, 106, 107, 108-9, $112,113,116,139,140$; risk of problematizing 101

Dreams of My Cousin Aurelia (Lorca) 116

Eclogue of Plácida and Victoriano (Enzina) 71

Edwards, Gwynne 134n2

Egginton, William 53, 55-6, 86,125

Eichelbaum, Samuel 123

El Caracol theater club 8, 91

El Debate newspaper 32

El Liberal newspaper 32, 94

Éluard, Paul 2

Enzina, Juan del: Eclogue of Plácida and Victoriano 71, 72

Estévez-Ortega, Enrique 75

European comic tradition 58
The Fairground Booth (Blok) 48, $66 \mathrm{n} 6$

Falla, Manuel de 45, 49, 50, 75

Fascism 4

Federico and his World (Francisco García Lorca) 55

Federico García Lorca Foundation 12

Fermín Galán 94

Fernández Almagro, Melchor 6, 31, $33,35,36,43 \mathrm{n} 7,46,49,94$

Fernández Cifuentes, Luis 12, 21, 30, 77,78

Fernández Muriedas, Pío 96

The Final Banquet (Lorca) 33

The Foolish Lady (Lope de Vega) 5, 95

Fort, Paul 12, 32

France, Anatole 65n1

Franco, Francisco 115

French structuralism 26

Freud, Sigmund 102

From Morn to Midnight (Kaiser) 104

Fuchs, Elinor 48, 90, 101, 104; The Death of Character 19

Fuenteovejuna (Lope de Vega) 97, 100

Gallego Burín, Antonio 17, 36, 73, 75, 90, 93

García Maestro, Jesús 130

García Lorca, Federico see Lorca

García-Posada, Miguel 12, 25, 70, 120

Gate Theatre, London 115

Gaylord, Mary M. 56

Gerling, David R. 47

Gibson, Ian 1, 33, 129

Giménez Caballero, Ernesto 42

The Girl of Gomez Arias

(Calderón) 91

The Girl Who Waters the Basil, and the Inquisitive Prince (Lorca) 49

Girondo, Oliverio 47

Gómez de la Serna, Ramón 42

Gómez Torres, Ana M. 72, 103

González Catoyra, J. 120

Graham-Lujan, James 139

The Great Theater of the World (Calderón) 17, 68, 73-6, 80, 89, 91-3, 112

Gross, Kenneth 57

Gruber, William 27

Guerrero, María 6

Guillén, Jorge 1, 25, 35, 99

Gypsy Ballads (Lorca) 1, 25, 92, 120-1 
Harris, Derek 68, 69

Havard, Robert G. 37

Heraldo de Madrid newspaper 41, 95,114

The Hermitage, the Fountain, and the River (Marquina) 36, 116, 117

Hernández, Mario 48, 65n2

Hernández, Miguel: He Who Has Seen You and He Who Sees You and the Shadow of What You Were 102

Hernani (Hugo) 93

The Heroism of a Lady, or the Tyranny of Her Force (Villanueva y Madrid) 38

He Who Has Seen You and He Who Sees You and the Shadow of What You Were (Hernández) 102

The Hidden Fountain (Marquina) 119,121

History of Spanish Theater (Huerta Calvo) 137

Honzl, Jindřich 84

The House of Bernarda Alba (Lorca) $3,70,111,113-15,117,123$

Huélamo Kosma, Julio 69

Huerta Calvo, Javier 70, 73, 87n9, 137, 139

Hugo, Victor 93

Humphries, Rolfe 2

Ibsen, Henrik 123

Ideas about the Novel (Ortega y Gasset) 34

intentionality/unintentionality dichotomy 25-7

In the Frame of Don Cristóbal (Lorca) $28,45,47,49,57,58,96$

Jakobson, Roman 72

Jarry, Alfred 48

The Jealous Extremaduran

(Cervantes) 125

Jerez-Farrán, Carlos 78

Jiménez Fraud, Alberto 30

Jiménez, Juan Ramón 31

Johnson, Roberta 129, 133

Josep Feliu i Codina (drama) 116

The Julianes (Marquina) 119

Kaiser, Georg 104

Kasten, Carey 91

King Alfonso XIII 91, 93, 109n2, 119

King Ferdinand VII 23, 37

Kleist, Heinrich von 48
La Barraca 8-9, 52, 54, 71, 94-5, 96, 97, 104

La Epoca newspaper 32

Laffranque, Marie 10, 101, 102

La Gaceta Literaria (journal) 42, 92, 93, 112, 119

La Libertad newspaper 32

Lanz, Hermenegildo 45, 50

Larrea, Juan 2

Lasso de la Vega, Francisco de Paula 38

La Vanguardia newspaper 38, 39

La Voz newspaper 117, 118

Lehrstuck (Brecht) 105

León, María Teresa 99

Life Is A Dream (Calderón) 54

Linares-Rivas, Manuel 116

Lola Membrives 95

Lope de Vega: The Foolish Lady 5, 95; Fuenteovejuna 97, 100

Lope de Vega, Félix 52, 53

Lorca, Federico García 1, 13, 22n6; The Billy-Club Puppets 7-8, 15, 57, 58; Blood Wedding 8, 19, 20-1, 22n4, 30, 67, 95, 111-16, 111-23, 125-7, 129-33, 138; The Butterfly's Evil Spell 4-5, 7, 82, 127, 139;

The Destruction of Sodom 113; dislike contemporary stage 8 ; Dona Rosita the Spinster 116; The Dream of Life 24, 89, 90, 106, 107-9, 112-13, 116, 139, 140; Dreams of My Cousin Aurelia 116; As Five Years Pass 116; In the Frame of Don Cristóbal 57-8, 96; Gypsy Ballads 1, 92, 121; The House of Bernarda Alba 3, 111, 113-15, 117, 123; international image of 3; The Love of Don Perlimplin and Belisa in the Garden 7-8, 102, 111, 120; Mariana Pineda 5, 6, 7, 44n13, 127; metacritical account 9-12; personal journey in New York 1-2; Poet in New York 1-2, 3, 139; The Public 7-11, 16-17, 22n6, 24, 67, 75, 80-1, 89, 90, 101, 103-7, 112, 124; The Shoemaker's Prodigious Wife 28-30, 112-13; sign of apolitical stance 93-4; Yerma 111, 113-14, $118,122-3,125,127,132$

Lorca, Francisco García 55, 56, $109 \mathrm{n} 4,109 \mathrm{n} 6$

"Lorca myth" 4

Lorquian scholarship 9, 67, 98 


\section{Index}

Los Cuatro Vientos (magazine) 112

The Lost Grove (Alberti) 93

The Love of Don Perlimplin and Belisa in the Garden (Lorca) 7-8, 28, 45-7, 58, 60, 62-5, 102, 111,120

Loynaz, Dulce María 69

Lugné-Poe 12, 32

Lyceum Women's Club 48

Machado, Antonio 36

Machado, Manuel 28, 36

Maeterlinck, Maurice 48

"magnificiently Castillian" 114

Mallarmé, Stéphane 48

The Man Who Pretended to Be from Biscay (Cervantes) 45, 52-4

Maortua Ucelay, Pura 111

Mariana Pineda (Lorca) 5, 6, 7, 12, 14, 23, 24, 32, 34, 37-8, 44n13, 55, 127; vs. The Butterfly's Evil Spell 40-1; debut in Barcelona and Madrid 40; importance of 41; pragmatic factors 36 ; premiered at Teatro Goya of Barcelona 38-9; prospects for 35; in Teatro Fontalba of Madrid 41-2

Mariano de Paco 128

Marquina, Eduardo 6, 19, 23, 31, 35, 36, 39, 113, 117

Martínez Nadal, Rafael 10, 11, 16, $67,68,69,70,71,72,73,77-8$

Martínez Ruiz, José 75; see also Azorín

Martínez Sierra, Gregorio 6, 12-13, $24,30,31,32,33,34,35,40,43 n 6$

Martín, Javier Domingo 139

The Marvelous Puppet Show (Cervantes) 45, 52-3, 56

Marzanov, Konstantin 97

Master Pedro's traveling show (Don Quixote) (Cervantes) 55-7

Mayhew, Jonathan 114

The Mayor of Zalamea (Calderón) 74 Membrives, Lola 4, 6, 20, 35, 95, 112, 120-2, 135n4

Menarini, Piero 24, 28, 33, 38, 46, 49

Menéndez Pelayo, Marcelino 73-4

Meyerhold, Vsevolod 48

A Midsummer Night's Dream

(Shakespeare) 18, 27, 78, 82, 83, 89

Monegal, Antonio 69, 70

Moragas, Carmen 6
Mora Guarnido, José 45, 50-1

Mukařovský, Jan 25-8

Mundo Gráfico magazine 94

Muñiz, Alfredo 114, 129

Muñoz-Alonso, Agustín 93

Muntaner, Joaquín 39, 94

musical puppet theater 49

mysterium 104-5

Mystery Play of the Three Wise Kings 49,81

Nelson, Bradley J. 87n7

Neruda, Pablo 47

The New Romanticism (Díez Fernández) 93

"new versus old" dichotomy 118

Nieto, Fernando 38

Norton, W.W. 2, 11

O’Connell, Richard L. 139

Of Love. Theater of Animals (Lorca) 33

Old Pagan Woman 114

Old Testament 113

"On the Puppet Theater" (Kleist) 48

The Origin of German Tragic Drama (Benjamin) 87n8

Orpheus (Cocteau) 79

Ortega y Gasset, José 23-4, 34, 102

Outward Bound (Vane) 75

Palacios, Leopoldo-Eulogio 93

Pasqual, Lluís 69, 140

The 'Pastor-Bobo' in the Spanish

Theatre before the Time of Lope de Vega (Brotherton) 71-2

Peral Vega, Emilio 96

Percas de Ponseti, Helena 56

Pérez Coterillo, Moisés 69

The Phantom Lady (Calderón) 74

"picturesque elements" 115

Pinillos, José López 116

Pirandello, Luigi 15, 16, 47, 55, 83;

Six Characters in Search of an

Author 76, 79; theatricalism 89;

Tonight We Improvise 89

Piscator, Erwin 98, 105; The Political Theater 93

Plato 11, 33

playwright: as producer 5-9

"poetic fantasy," fuzzy concept of 127

Poet in New York (Lorca) 1-2, 3, 139

The Political Theater (Piscator) 93

Pomo, Roberto D. 115 


\section{The Primitive Auto Sentimental}

(Lorca) 33

Primo de Rivera, Miguel 7, 23, 34, 109n2

The Public (Lorca) 7-11, 16-17, 22n6, 24, 67, 75, 76-7, 80, 81, 84, 86, 89, 90, 101, 103, 104, 106, 107, 112, 124; Act IV of $82-3,105$; Act V of 83; textual transmission of 68-9

Puchner, Martin 27; Stage Fright 9

Puppet: An Essay on Uncanny Life (Gross) 57

puppet plays 46, 47, 55; The BillyClub Puppets (Lorca) 45, 46, 49; vs. 'farces' for actors 46; In the Frame of Don Cristóbal (Lorca) 28, 45, 49 puppet theater 48, 55

puppet tradition: of Italian origins 57

Quem quaeritis, liturgical drama 80

Reichenberger, Arnold G. 135n6

Reinhardt, Max 74, 91

"revolutionary theater" 100

Rivas Cherif, Cipriano 5, 8, 22n5, 62, 90-4, 97, 100, 111, 118, 120

Rodríguez Cuadros, Evangelina 54

Rodríguez Rapún, Rafael 113

Rodriguez-Solás, David 109n7

Romeo and Juliet (Shakespeare) 69, 70, 79, 82, 85-6, 105-6

The Routledge Drama Anthology and Sourcebook: From Modernism to Contemporary Performance (Gale) 11

Rubia Barcia, José 70-1

de Rueda, Lope 52, 66n4, 66n5

Salado, José Luis 118, 119

Salazar, Adolfo 56

Salinas, Pedro 99

Sáenz de la Calzada, Luis 113

Santiago Romero, Sergio 139

Sarduy, Severo 70

Second Spanish Republic 17, 18, 90, 91, 93, 97; proclamation of 94

Señora ama (Benavente) (1908) 116

Shadows (Lorca) 33

Shakespeare, William 18, 27, 78, 82, 83, 89; A Midsummer Night's

Dream 18, 27, 78, 82, 83, 89;

Romeo and Juliet 69, 70, 79, 82, 85-6, 105-6
Shklovsky, Viktor 72

The Shoemaker's Prodigious Wife

(Lorca) 28, 29, 30, 35, 45, 46, 53, 58, 91, 95, 106, 112, 113; generic indeterminacy of 61 ; prologue of 60

Six Characters in Search of an Author (Pirandello) 76, 79, 89

Smith, Paul J. 4, 10, 77, 114, 138

Soria Olmedo, Andrés 139

Soufas, C. Christopher 27

Spadaccini, Nicholas 54

Spanish Civil War 2, 3, 21, 30, 90, 102, 111, 116

Spanish folkloric tradition 56

Spanish modernism 1

Spanish monarchy 91

"Spanish Puppets": tradition of 50

Spanish theatrical industry 6, 52,101

Spanish theatrical tradition 112

"Spanish Youth Poll" series, in $\mathrm{La}$ Gaceta Literaria 42

"stage figure" concept 33

Stage Fright (Puchner) 9

Stainton, Leslie 1

"strategic" value 111

"Structure, Sign, and Play in the Discourse of the Human Sciences"

(Derrida) 43n3

Szondi, Peter 124, 135

Talens, Jenaro 54

Teatro Beatriz of Madrid 117

Teatro completo (Huerta Calvo) 139

Teatro Eslava of Madrid 23-4, 30

Teatro Español of Madrid 8, 112, $113,122,140$

Teatro Fontalba of Madrid 36

Theater of Souls (Lorca) 33

theatricalism 89

Tirso de Molina 71, 139

Tonight We Improvise (Pirandello) 89

Torre, Guillermo de 46, 109-10n8

Torres Naharro, Bartolomé 72

Torres Nebrera, Gregorio 25

traditional criticism 78

Trigueros-Ramos, Luis 70, 73

The Two Talkers (Cervantes) 49, 52, 96

Tynianov, Yury 112

Ubu Roi (Jarry) 48

Unamuno, Miguel de 118 
158 Index

The Uninhabited Man (Alberti) 92, 93,102

The Unloved Woman (Benavente) 116, 117, 118, 119

Uruguayan press 127

Valbuena Prat, Ángel 73, 74, 75, 90, 93

Valle-Inclán, Ramón M. 118

Vane, Sutton 75

Veltruský, Jiří 33, 84

Vilches de Frutos, María T. 133

Villaespesa, Francisco 35

Villanueva y Madrid, Francisco 38

Waiting for Godot (Beckett) 104

Welles, Orson 69

Wright, Sarah 4

Xirgu, Margarita 5-8, 14, 18, 20-1, $35-6,39,42-3,90-4,97-9,100$, $101,111-12$

Yeats, W. B. 27

Yerma (Lorca) 19, 21, 67, 99, 100, 104, 111, 113, 114, 118, 122, 123 , $125,127,132$

Zich, Otakar 43n8 